medRxiv preprint doi: https://doi.org/10.1101/2020.04.23.20076273; this version posted April 28, 2020. The copyright holder for this preprint (which was not certified by peer review) is the author/funder, who has granted medRxiv a license to display the preprint in perpetuity. It is made available under a CC-BY-NC-ND 4.0 International license .

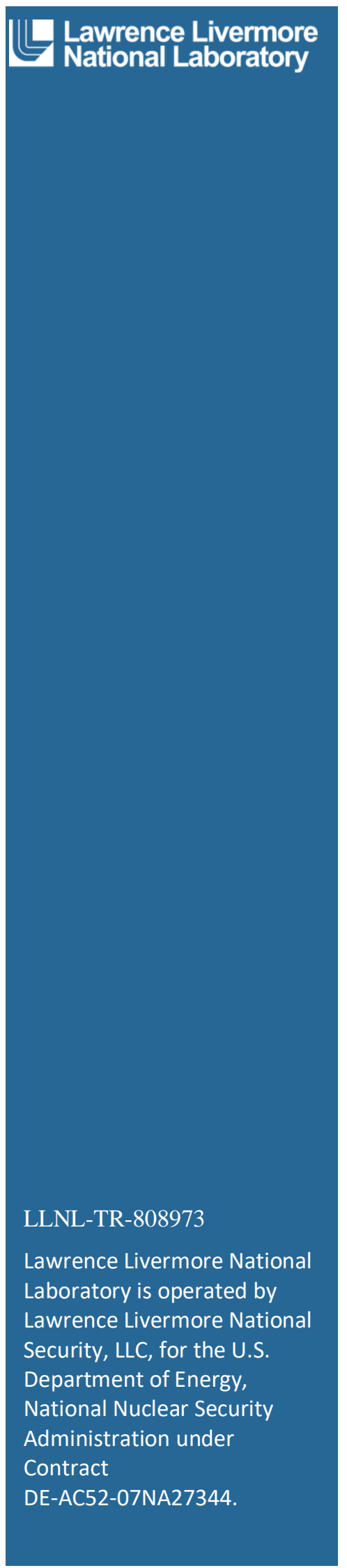

\title{
Particle Based Model for Airborne Disease Transmission
}

\author{
Michael B Dillon \\ Charles F Dillon
}

April 2020

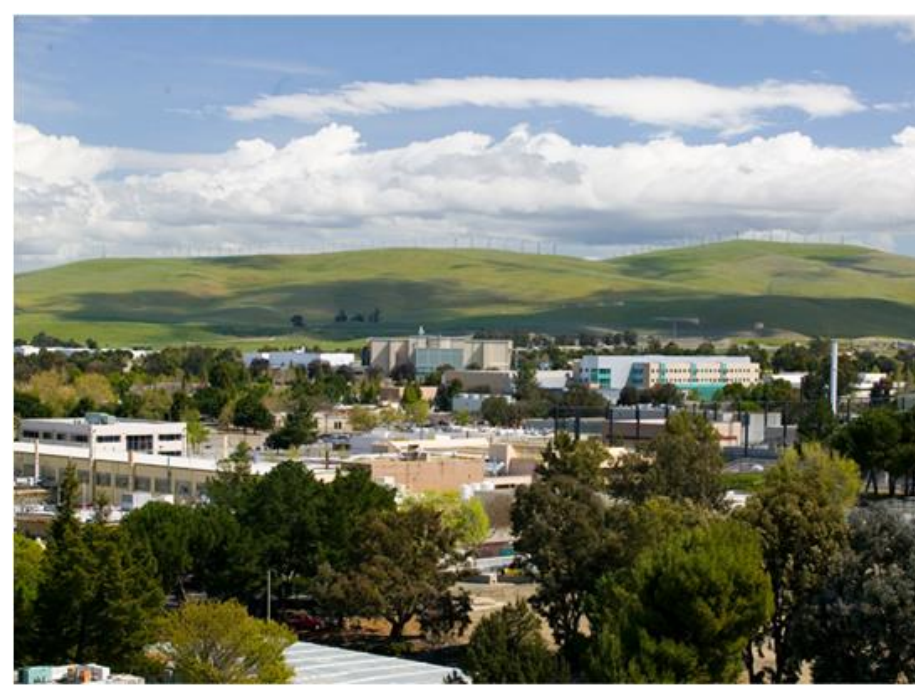

NOTENTHispreprinfreports new research that has not been certified by peer review and should not be used to guide clinical practice. 
medRxiv preprint doi: https://doi.org/10.1101/2020.04.23.20076273; this version posted April 28, 2020. The copyright holder for this preprint

(which was not certified by peer review) is the author/funder, who has granted medRxiv a license to display the preprint in perpetuity.

It is made available under a CC-BY-NC-ND 4.0 International license .

\section{Auspices and Disclaimer}

This work was performed under the auspices of the U.S. Department of Energy by Lawrence Livermore National Laboratory under Contract DE-AC52-07NA27344.

This document was prepared as an account of work sponsored by an agency of the United States government. Neither the United States government nor Lawrence Livermore National Security, LLC, nor any of their employees makes any warranty, expressed or implied, or assumes any legal liability or responsibility for the accuracy, completeness, or usefulness of any information, apparatus, product, or process disclosed, or represents that its use would not infringe privately owned rights. Reference herein to any specific commercial product, process, or service by trade name, trademark, manufacturer, or otherwise does not necessarily constitute or imply its endorsement, recommendation, or favoring by the United States government or Lawrence Livermore National Security, LLC. The views and opinions of authors expressed herein do not necessarily state or reflect those of the United States government or Lawrence Livermore National Security, LLC, and shall not be used for advertising or product endorsement purposes. 
medRxiv preprint doi: https://doi.org/10.1101/2020.04.23.20076273; this version posted April 28, 2020. The copyright holder for this preprint (which was not certified by peer review) is the author/funder, who has granted medRxiv a license to display the preprint in perpetuity.

It is made available under a CC-BY-NC-ND 4.0 International license.

M Dillon and

Particle Model for

C Dillon

Airborne Disease Transmission

\section{Particle Based Model for Airborne Disease}

2 Transmission

3

4 Authors

5 Michael B Dillon, ${ }^{a,}$ dillon7@llnl.gov

6 Charles F Dillon

7

$8{ }^{a}$ Lawrence Livermore National Laboratory

$9{ }^{*}$ Corresponding author

10 
medRxiv preprint doi: https://doi.org/10.1101/2020.04.23.20076273; this version posted April 28, 2020. The copyright holder for this preprint (which was not certified by peer review) is the author/funder, who has granted medRxiv a license to display the preprint in perpetuity. It is made available under a CC-BY-NC-ND 4.0 International license .

M Dillon and

C Dillon
Particle Model for Airborne Disease Transmission

\section{Executive Summary}

12 Prior literature documents cases of airborne infectious disease transmission at distances

13 ranging from $\geq 2 \mathrm{~m}$ to inter-continental in scale. Physics- and biology- based models describe

14 the key aspects of these airborne disease transmission events, but important gaps remain. This

15 report extends current approaches by developing a new, single-particle based theory that (a)

16 assesses the likelihood of rare airborne infections (where individuals inhale either one or no

17 infectious particles) and (b) explicitly accounts for the variability in airborne exposures and

18 population susceptibilities within a geographic region of interest. For these hazards, airborne particle fate and transport is independent of particulate concentration, and so results for complex releases can be determined from the results of many single-particle releases.

21 This work is intended to provide context for both (a) the initial stages of a disease outbreak and

22 (b) larger scale ( $\geq 2 \mathrm{~m}$ ) disease spread, including distant disease "sparks" (low probability, 23 unexpected disease transmission events that infect remote, susceptible populations). The physics of airborne particulate dispersion inherently constrains airborne disease transmission. As such, this work suggests results that, a priori, may be applicable to many airborne diseases.

Model Predictions:

i. Modeling predictions of the single-particle transmission kernel suggest that outdoor airborne disease transmission events may occur episodically as the infection probabilities can vary over many orders of magnitude depending on the distance downwind; specific virus, prion, or microorganism; and meteorological conditions.

ii. Model results suggest that, under the right conditions, an indoor infected person could spread disease to a similar, or greater, number of people downwind than in the building they occupy. However, the downwind, per-person infection probability is predicted to be lower than the within-building, per-person infection probability. This finding is limited to airborne transmission considerations.

iii. This work suggests a new relative disease probability metric for airborne transmitted diseases. This metric, which is distinct from the traditional relative risk metric, is applicable when the rate at which the infectious agent losses infectivity in the atmosphere is $\lesssim 1 \mathrm{~h}^{-1}$. 
medRxiv preprint doi: https://doi.org/10.1101/2020.04.23.20076273; this version posted April 28, 2020. The copyright holder for this preprint

(which was not certified by peer review) is the author/funder, who has granted medRxiv a license to display the preprint in perpetuity.

It is made available under a CC-BY-NC-ND 4.0 International license .

M Dillon and

C Dillon
Particle Model for

Airborne Disease Transmission

\section{Table of Contents}

2. Physics- and Biology- Based Airborne Transmission Modeling

2.3. Discrete Nature of Airborne Infection ....

3. Theory.

3.1. Absolute (Mean) Infection Probabilities for Geographic Regions

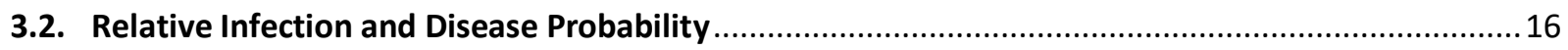

3.3. Indoor Airborne Particle Dynamics.

4. Results

4.1. Upper Bound on Absolute Infection Probability vs. Distance.

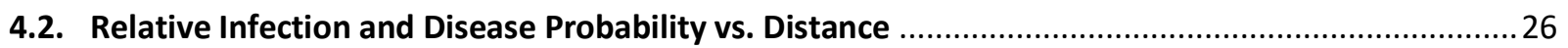

4.3. Model Prediction - Outbreak Data Comparison

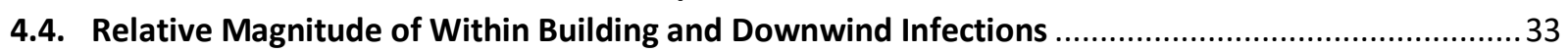

5. Discussion

5.1. Characterizing Airborne Disease Spread.

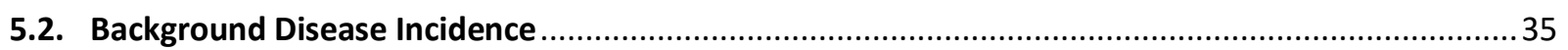

5.3. Key Infectious Agent/Disease Characteristics

5.3.1. Number of Infectious Particles Emitted: Total Particles Released ......................................... 36

5.3.2. Single Particle Infectivity: [Single Particle Infection Probability] ................................................37

5.3.4. Loss of Particle Infectivity While Airborne: Affects [Normalized TSIAC] ................................... 38 
medRxiv preprint doi: https://doi.org/10.1101/2020.04.23.20076273; this version posted April 28, 2020. The copyright holder for this preprint

(which was not certified by peer review) is the author/funder, who has granted medRxiv a license to display the preprint in perpetuity.

It is made available under a CC-BY-NC-ND 4.0 International license.

M Dillon and

C Dillon

Particle Model for

Airborne Disease Transmission

Supplemental Material A: Airborne Disease Transmission Literature Review. 66

Near Range $(<5 \mathrm{~m})$

Short Range ( $5 \mathrm{~m}$ to $50 \mathrm{~m}$ )

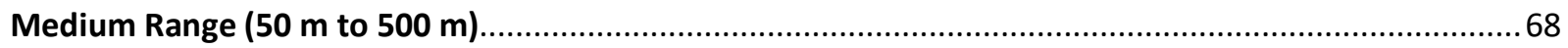

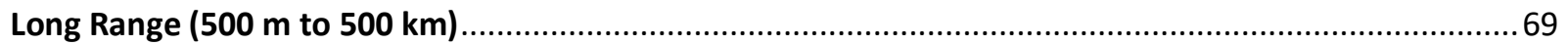

76

Continental and Global Range (>500 km)

Supplemental Material B: Key Atmospheric Transport and Dispersion Modeling Concepts

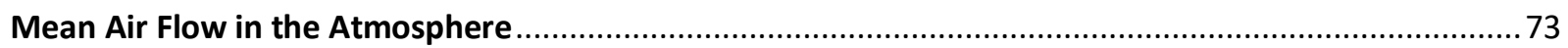

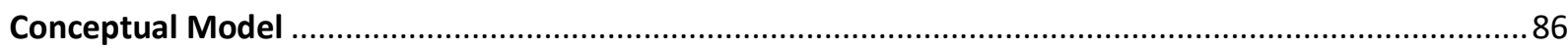

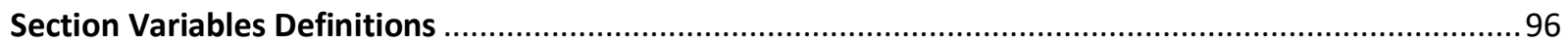

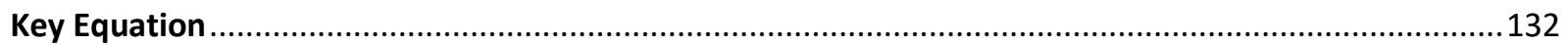

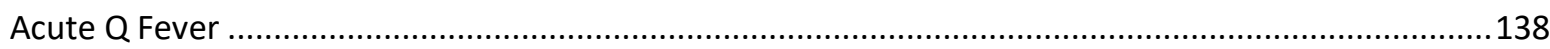


medRxiv preprint doi: https://doi.org/10.1101/2020.04.23.20076273; this version posted April 28, 2020. The copyright holder for this preprint (which was not certified by peer review) is the author/funder, who has granted medRxiv a license to display the preprint in perpetuity. It is made available under a CC-BY-NC-ND 4.0 International license .

M Dillon and

C Dillon
Particle Model for Airborne Disease Transmission

\section{Introduction}

113 Particles of all types are routinely transported in the atmosphere, including infectious disease 114 particles. The physics of the local airborne person-to-person inhalation pathway of infectious 115 disease transmission was investigated by early Public Health investigators who were focused on 116 human Tuberculosis and Measles outbreaks [1]-[3]. As documented in the Supplemental

117 Material A: Airborne Disease Transmission Literature Review, airborne human, veterinary, and 118 plant disease transmission and other bioaerosol transmission events naturally occur across a

119 wide range of distance scales, from two meters up to and including inter-continental 120 transmission. These multiscale transmission events include bacteria, viruses, and fungi.

121 The population disease burden caused by infectious agents that are transmitted through the air 122 remains substantial as lower respiratory infections and Tuberculosis are the fourth and tenth, 123 respectively, leading causes of death world-wide [4], [5]. We adopt here the classic definition of 124 the airborne disease transmission pathway as the inhalation of $\leq 5 \mu \mathrm{m}$ aerodynamic diameter 125 (AD) infectious particles that have traveled airborne a distance of two or more meters. ${ }^{1}$ We 126 note that the airborne pathway can be the primary means of disease transmission or a 127 secondary pathway when more than one disease transmission pathway is active, including the 128 droplet (> $5 \mu \mathrm{m} \mathrm{AD} \mathrm{particles)} \mathrm{or} \mathrm{contact} \mathrm{pathways,} \mathrm{e.g.,} \mathrm{[6],} \mathrm{[7].}$

Physics- and biology- based atmospheric transport and dispersion models have been developed to predict airborne infectious disease transmissions, exposures, and the subsequent infection or disease incidence to various degrees of accuracy, e.g., [8]. However, important scientific gaps remain (discussed below). The aim of physics-and biology- based models is to determine (a) the extent of airborne disease spread (including identification of disease sources) and (b) disease outbreak control strategies. These remain key areas of research and this report extends current, physics- and biology- based modeling approaches. Specifically, we develop a new theory that provides methods and metrics to assess rare, but finite airborne infection incidence

137 (single particle airborne disease transmission: dilute atmospheric exposures where an 138 individual inhales either one infectious particle ${ }^{2}$ or none at all).

\footnotetext{
${ }^{1}$ For readability, much of the focus of this paper is on $\leq 5 \mu \mathrm{m}$ AD infectious particles. However, we note that the research presented in this paper is also relevant to larger particles.

${ }^{2}$ The infectious particle can, in theory, carry one or more infectious pathogens and be physically larger than the pathogen itself, see the 5.3.2.Single Particle Infectivity section.
} 
medRxiv preprint doi: https://doi.org/10.1101/2020.04.23.20076273; this version posted April 28, 2020. The copyright holder for this preprint (which was not certified by peer review) is the author/funder, who has granted medRxiv a license to display the preprint in perpetuity. It is made available under a CC-BY-NC-ND 4.0 International license .

M Dillon and

Particle Model for C Dillon Airborne Disease Transmission

140 In this report, we highlight implications for two distinct categories of diseases. In the first case, 141 the disease does not have significant individual to individual transmission $\left(R_{0}<1\right) .{ }^{3}$ One

142 example is Q Fever in humans in which the source of infectious particles is outdoors (i.e., 143 infected livestock and/or contaminated soil) and infections are not typically passed from one

144 human to another. In the second case, the disease has notable individual to individual 145 transmission $\left(R_{0}>1\right)$ and so there may be the potential for rapid disease spread. We note that 146 both disease cases may have multiple disease transmission pathways, including direct contact, 147 indirect contact, or ingestion.

${ }^{3} R_{0}$ is the basic reproduction number and is defined as the expected number of secondary cases produced by a single (typical) infection in a totally susceptible population (dimensionless). If $R_{0}<1$, then an exposed person can become ill but typically does not infect others. If $R_{0}>1$, then further person-to-person infection spread may occur. 
medRxiv preprint doi: https://doi.org/10.1101/2020.04.23.20076273; this version posted April 28, 2020. The copyright holder for this preprint (which was not certified by peer review) is the author/funder, who has granted medRxiv a license to display the preprint in perpetuity.

It is made available under a CC-BY-NC-ND 4.0 International license .

M Dillon and

C Dillon
Particle Model for

Airborne Disease Transmission

\section{Physics- and Biology- Based Airborne Transmission Modeling}

150 Airborne transmission of infectious disease from an infected host to a susceptible individual

151 occurs in three phases: (a) the release of infectious particles into the air; (b) particle transport

152 to, and the exposure of, downwind individuals; and (c) the infection of susceptible exposed

153 individuals (receptors), see Figure 1. Physics and biology based models mathematically describe

154 each of these three phases. They estimate the number and/or distribution of subsequent

155 infections using previously determined principles combined with key particle, environmental,

156 infectious organism, and receptor properties, see Table 1. This paper focuses on improvements

157 for modeling the second and third phases.

158

159

Figure 1. Conceptual model of the airborne transmission pathway

Release Phase

Release determines

infectious agent,

particle properties and numbers
Fate, Transport, and Exposure Phase

Exposures are determined by particle, infectious agent, environmental, and receptor (host) properties
Infection Phase

Infections are determined by particle, infectious agent, and receptor (host) properties
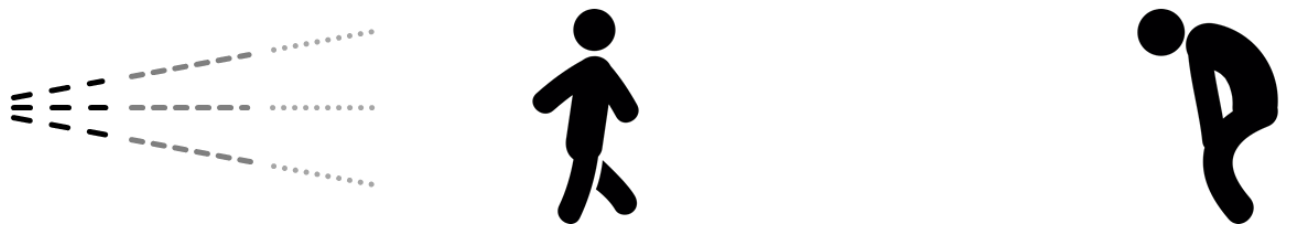
medRxiv preprint doi: https://doi.org/10.1101/2020.04.23.20076273; this version posted April 28, 2020. The copyright holder for this preprint (which was not certified by peer review) is the author/funder, who has granted medRxiv a license to display the preprint in perpetuity.

It is made available under a CC-BY-NC-ND 4.0 International license .

M Dillon and

C Dillon

Particle Model for

Airborne Disease Transmission

Table 1. Key properties affecting the airborne disease transmission pathway

Particle

Physical

Properties

Particle number

Particle size (aerodynamic diameter) and infectivity* as a function of (a) time, (b) the infectious agent and (c) environmental conditions (e.g., temperature, humidity, solar radiation)

\section{Environmental \\ Properties}

Wind speed, Turbulence, Precipitation, Temperature,

Humidity, Solar radiation, Terrain/Land Use, and

Built Environment (for indoor exposures)

Infectious

Agent

Properties
Infectivity* as a function of (a) time and

(b) particle, environmental, and receptor properties

Pathogenicity (ability to cause disease)

Breathing rate as a function of the receptor and environmental properties

(e.g., activity, temperature)

\section{Receptor (Host) Properties}

Number of receptors (population)

Factors affecting infection probability*

Age, Gender, Nutrition, Health Status, Immune status

* The probability that an inhaled particle causes infection for a given receptor is affected by parameters in several columns. Specifically, it depends on a combination of particle, infectious agent, and receptor properties - each of which depends, in part, upon environmental properties. 
medRxiv preprint doi: https://doi.org/10.1101/2020.04.23.20076273; this version posted April 28, 2020. The copyright holder for this preprint (which was not certified by peer review) is the author/funder, who has granted medRxiv a license to display the preprint in perpetuity. It is made available under a CC-BY-NC-ND 4.0 International license .

M Dillon and

C Dillon
Particle Model for Airborne Disease Transmission

\subsection{Dilute Particle Considerations}

171 If airborne particles are added to a small mass of air, the resulting particle concentration is, in

172 many cases, dilute and the material's presence will not significantly affect the local

173 atmosphere. ${ }^{4}$ Therefore the downwind transport and dilution (dispersion) of such material can

174 be determined from environmental (meteorological + surface) considerations alone. Also, as a

175 practical matter, dilute particles can be assumed to behave independently in the atmosphere,

176 i.e., there is essentially no particle-to-particle interaction. Therefore, the downwind exposure

177 associated with any release of dilute material is mathematically identical to the sum of the

178 exposures associated with many independent "point" releases that occur at specific points in

179 time and space. Thus, insights and model results derived for single particles released at a

180 specific location and time can be combined to characterize the more complex cases, such as

181 complex particle aerodynamic diameter distributions and/or time varying locations and release

182 quantities.

\subsection{Advantages of Spatial and Temporal Averaging}

Physics-based models of atmospheric transport and dispersion simulate the effects of the physical processes which determine the air concentrations of infectious particles downwind of a release. All practical dispersion models resolve only a portion of the atmospheric motions and physical processes, typically the regional winds that transport particles downwind. The effects of the unresolved processes, such as turbulent eddies that dilute the airborne particulate cloud, are parameterized, often using empirical data. An important consequence is that model predictions can be much more accurate with predicting metrics that are spatially and/or temporally integrated (or averaged), see Supplemental Material B: Key Atmospheric Transport and Dispersion Modeling Concepts. This study uses the exposure integrated over a (a) a disc (circular area) and (b) along a circle arc both centered at the release point, see Figure $\mathbf{2}$. These exposure metrics also eliminate sensitivity to wind direction uncertainty, although we note that other uncertainties, such as wind speed, remain. ${ }^{5}$

${ }^{4}$ The number of particles required to change the behavior of the local atmosphere depends on the (a) atmospheric volume of interest, (b) particle size and density, (c) release duration, and (d) ambient wind speed [9]. For context, assuming a light wind $\left(1 \mathrm{~m} \mathrm{~s}^{-1}\right)$ and monodisperse particles as dense as water $\left(1000 \mathrm{~kg} \mathrm{~m}^{-3}\right)$; a $1 \mathrm{~m}^{3}$ release volume can contain at least $10^{16} 0.1 \mu \mathrm{m}$ diameter particles, $10^{13}$ $1 \mu \mathrm{m}$ diameter particles, or $10^{10} 10 \mu \mathrm{m}$ diameter particles without violating this assumption.

${ }^{5}$ Standard wind measurements are typically only accurate to within 5 degrees [10]-[14]. Thus plume predictions based on such a single measurement may be offset by as much as a $1 \mathrm{~km}$ by the time the plume is $10 \mathrm{~km}$ downwind. 
medRxiv preprint doi: https://doi.org/10.1101/2020.04.23.20076273; this version posted April 28, 2020. The copyright holder for this preprint (which was not certified by peer review) is the author/funder, who has granted medRxiv a license to display the preprint in perpetuity. It is made available under a CC-BY-NC-ND 4.0 International license .

M Dillon and C Dillon Particle Model for Airborne Disease Transmission

Figure 2. Illustration of airborne exposure (plume) integrated over a (left) a disc and (right) along a circle arc, both centered at the release point.

\section{Release}

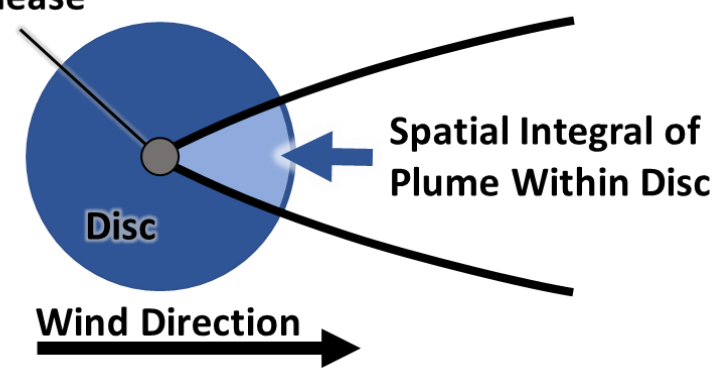

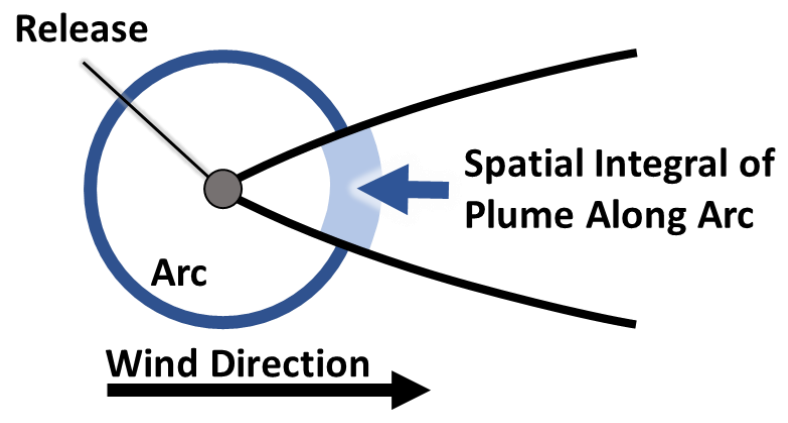

202

\subsection{Discrete Nature of Airborne Infection}

205

206

207

208

209

210

211

212

213

214

215

216

217

218

219

220

221

The research community understands that airborne, infectious agents are carried as or within discrete particles, either as individual viruses, prions, or microorganisms or as part of a larger particle which could contain more than one infectious agent. However, there has been limited attention, within the context of risk assessment, as to how the discrete, quantal nature of airborne particulate exposures affect downwind infection probabilities. This scientific gap is particularly notable for rare exposures - defined for the purposes of this paper as exposures where a typical individual inhales either one infectious particle or none at all, see Supplemental Material C: General Theory.

Historically, rare exposure infection probabilities have been estimated by (a) extrapolating population-mean dose-response models to "less-than-one" infectious agent exposures ${ }^{6}$ or (b) using "single hit" models. Population-mean dose-response models are often based on data from toxicology experiments that use multiple infectious agent exposures to extrapolate to single particle exposures. Single hit models assume that (a) the number of infectious agents inhaled by a given individual is a random number whose expected value equals the predicted exposure and (b) the likelihood of an individual inhaling an infectious organism is independent of the total number of infectious agents inhaled. Effectively each infectious agent inhaled is assumed to cause infection independently, although the overall infection probability can

\footnotetext{
6 "Less than one" exposures occur when in a mathematical model the expectation value of the individual exposure is less than one infectious agent.
} 
medRxiv preprint doi: https://doi.org/10.1101/2020.04.23.20076273; this version posted April 28, 2020. The copyright holder for this preprint (which was not certified by peer review) is the author/funder, who has granted medRxiv a license to display the preprint in perpetuity. It is made available under a CC-BY-NC-ND 4.0 International license .

M Dillon and

C Dillon

Particle Model for Airborne Disease Transmission

222 depend on other factors, including exposure to other viruses or microorganisms [3], [15]-[19].

223 Recent work has extended single hit models to consider infectious agents randomly aggregating

224 while in the environment, see [20], [21] and refs therein. However with the exception of a

225 single theoretical treatment of a complex exposure distribution [19], we did not identify a prior

226 approach that explicitly addresses a real-world situation in which (a) a distribution of infectious

227 particles types is aerosolized, (b) the number of infectious agents present in each particle may

228 scale with particle volume (i.e., is not random), and (c) environmental fate (and hence

229 downwind exposures) vary by particle type (again is not random).

230 Separately, we note that the current physics-based airborne exposure models have been

231 validated against measurements of high concentrations of airborne particulates (and gases). As

232 such they do not explicitly consider the quantal nature of exposures inherent to rare exposures

233 to particulate matter, i.e., the downwind individuals are exposed to either one or no particles.

234 The theory developed later in the paper addresses this historical gap, see the 3. Theory section.

235

\subsection{Building Protection}

237 Ideally, airborne infectious particle risks would be assessed at the location where the exposure

238 takes place. It is generally acknowledged that buildings afford protection from outdoor airborne

239 infection. However most current assessments of downwind exposures to airborne infectious

240 particles only consider outdoor exposures and typically do not consider the degree to which

241 buildings protect their occupants from such hazards. For example, in a recent review of existing

242 pathogenic, bio-aerosol dispersion modeling literature; only two studies were included that

243 consider the degree to which indoor exposures may differ from outdoor exposures and no

244 general theory was discussed [8]. This gap is notable as (a) individuals spend about $85 \%$ of a

245 typical day indoors [22]; (b) outdoor airborne biological particles have been proven to infiltrate

246 indoors and be inhaled by building occupants, e.g., [23], [24]; and (c) the scientific and public

247 health communities have long recognized the importance of the contribution of indoor

248 exposures during disease outbreaks involving outdoor, airborne plumes of infectious particles.

249 For example, outdoor-origin fungal pathogens such as Aspergillus, including fumigatus and

250 flavus, and Histoplasma capsulatum are known pose a particularly severe hazard to indoor,

251 immune compromised individuals and hospital facilities are engineered to minimize such

252 concerns [25]-[29].

253 The degree to which building occupants are protected from outdoor, airborne, infectious

254 particles is determined by (a) the building air change rate (the rate at which outdoor air passes

255 through air handling systems, open windows and doors, and/or cracks in the building envelope)

256 and (b) indoor particle dynamics (e.g., deposition, resuspension and rate at which infectious 
medRxiv preprint doi: https://doi.org/10.1101/2020.04.23.20076273; this version posted April 28, 2020. The copyright holder for this preprint (which was not certified by peer review) is the author/funder, who has granted medRxiv a license to display the preprint in perpetuity. It is made available under a CC-BY-NC-ND 4.0 International license .

M Dillon and

Particle Model for

C Dillon Airborne Disease Transmission

257 agents lose infectivity), see Supplemental Material D: Indoor Particle Dynamics. We, and 258 collaborators, have recently developed a proof-of-concept method, Regional Shelter Analysis 259 (RSA), to (a) estimate the degree of protection US buildings provide against outdoor airborne 260 particulate hazards and (b) estimate total population exposures [30], [31]. Figure 3 illustrates 261 the RSA method for calculating building protection-adjusted population impacts resulting from 262 an estimate of the outdoor hazard. The example shown is for an external gamma radiation 263 hazard. The process for inhalation exposures is similar. US building protection against 264 particulate hazards varies strongly, i.e., by orders of magnitude, with particle size and building 265 use (occupancy). For context, being inside a typical US residence is expected to reduce outdoor 266 exposures by a factor of 5 for $1 \mu \mathrm{m}$ AD particles, a size typical of many individual bacteria [30]. 
medRxiv preprint doi: https://doi.org/10.1101/2020.04.23.20076273; this version posted April 28, 2020. The copyright holder for this preprint (which was not certified by peer review) is the author/funder, who has granted medRxiv a license to display the preprint in perpetuity.

It is made available under a CC-BY-NC-ND 4.0 International license .

M Dillon and

Particle Model for

C Dillon

Airborne Disease Transmission

Figure 3. Regional Shelter Analysis illustrative calculation (top panel) and summary (bottom pane). This schematic illustration uses an outdoor (external) radiation exposure and shelter quality (building protection) estimates. Potential applications and uses are listed.

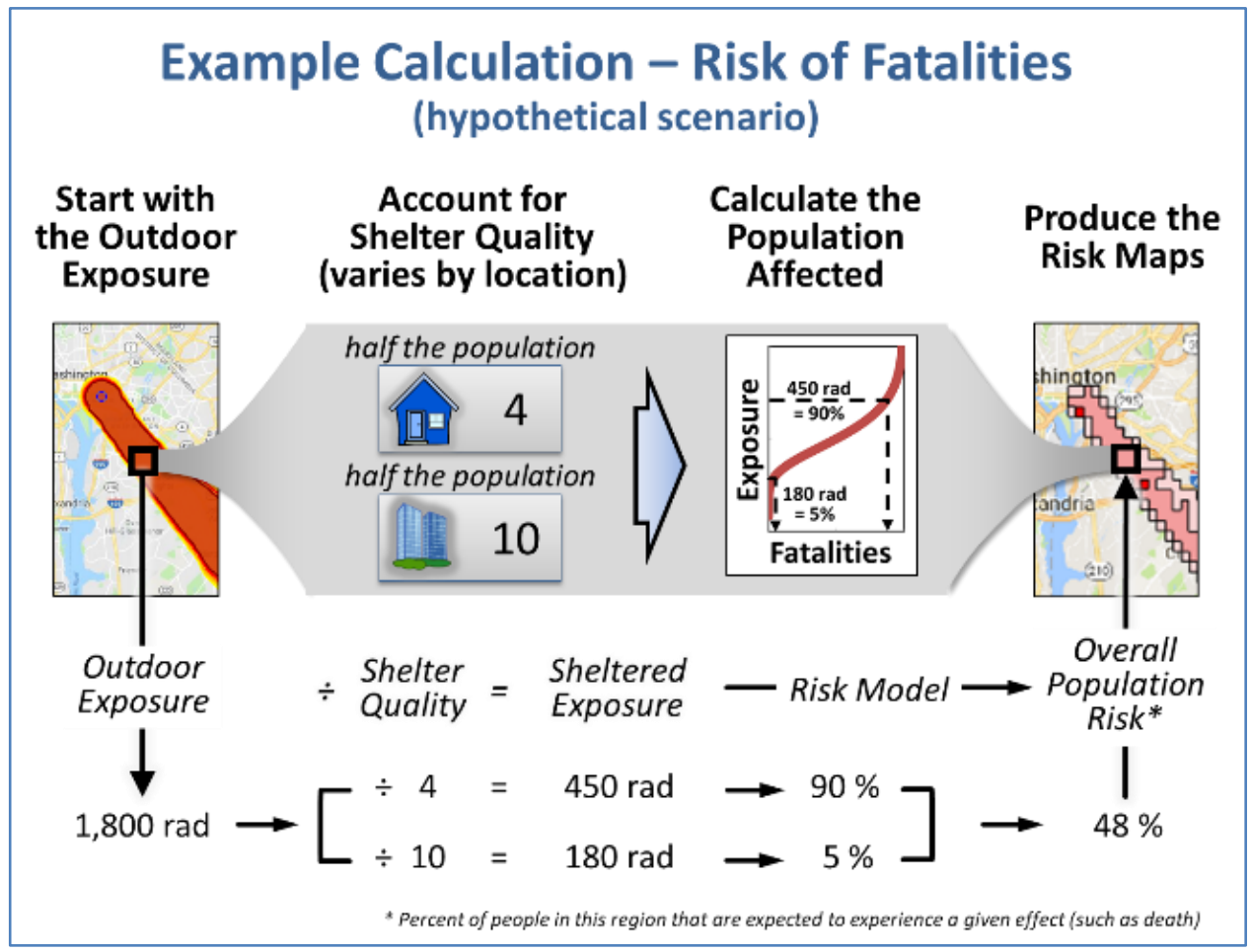

\section{Regional Shelter Analysis summary}

- Incorporates shelter quality into existing assessment methods

- Applicable to

- Nuclear, radiological, chemical, and biological acute and chronic hazards (e.g., outdoor particle air pollution, wildfire smoke)

- External radiation and inhalation exposure (rad and non-rad) pathways

- Spatial scales ranging from individual buildings to census tracts to entire countries

- Capable of using multiple data sources

- Elements being integrated into operational models

- US Department of Energy, NARAC

- US Department of Defense, HPAC

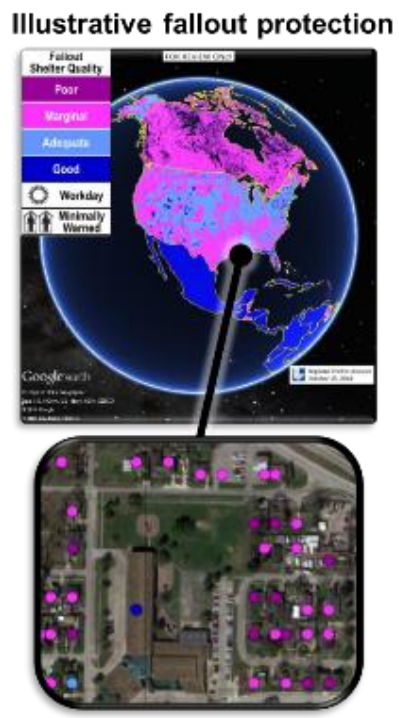


medRxiv preprint doi: https://doi.org/10.1101/2020.04.23.20076273; this version posted April 28, 2020. The copyright holder for this preprint (which was not certified by peer review) is the author/funder, who has granted medRxiv a license to display the preprint in perpetuity. It is made available under a CC-BY-NC-ND 4.0 International license .

M Dillon and

C Dillon
Particle Model for Airborne Disease Transmission

\section{Theory}

275 Theoretically, the total number of infections in a disease outbreak could be calculated by

276 considering every exposed person. Computationally this approach is challenging to implement,

277 due in part to the need to acquire high resolution input data such as individual exposures and

278 responses to each exposure. To provide an alternative approach, we develop here infection

279 probability prediction equations for (a) the number of airborne infections (and the absolute

280 airborne infection probability) expected in a specific geographic region for both the general and

281 the rare exposure cases (Equations 1 and 2 ) and (b) an equation that relates the relative

282 probability of airborne infection across two regions (Equation 3 ). Note that these, and

283 subsequent, equations can also be used directly without modification to estimate disease

284 probability and other probabilities of interest. These equations are based on the atmospheric

285 physics assumptions and considerations presented in the 2. Physics-and Biology-Based Airborne Transmission Modeling section. Supplemental Material C: General Theory formally derives these equations and provides more detail, including theory that considers multiple particle types that have varying infectivity and environmental fates. Supplemental Material D: Indoor Particle Dynamics provides more detail on Equations $\mathbf{5}$ to $\mathbf{7}$ which predict the degree to which buildings protect their occupants from outdoor airborne hazards; expected numbers of infections in the indoor environment from an indoor release; and the fraction of indoor, airborne, infectious particles that may exit a given building into the outdoor atmosphere.

\subsection{Absolute (Mean) Infection Probabilities for Geographic Regions}

Geographic regions, e.g., zip codes and census tracts, are often used when reporting epidemiological data and defining outbreak response zones, e.g., for quarantine and/or vaccination. In general, people within these geographic regions may have varying exposures and/or responses to a given exposure, e.g., individuals inside a building may receive a smaller exposure than those outside; immune compromised individuals may be more sensitive than a healthy person. To account for these considerations, we extend the previously developed Regional Shelter Analysis methodology [30], [31]. Specifically, we assign each group of people within a geographic region a linear scaling factor, termed adjustment factor, to account for both exposure and response variability.

For a given release, the total number of airborne infections in a region can be determined by rare. 
medRxiv preprint doi: https://doi.org/10.1101/2020.04.23.20076273; this version posted April 28, 2020. The copyright holder for this preprint

(which was not certified by peer review) is the author/funder, who has granted medRxiv a license to display the preprint in perpetuity.

It is made available under a CC-BY-NC-ND 4.0 International license .

M Dillon and

C Dillon
Particle Model for

Airborne Disease Transmission

[Airborne Infections] $\left(r_{\text {source }}, r\right)$

where

$r=$ a specific geographic region (dimensionless),

[Absolute Airborne Infection Probability] $\left(r_{\text {source }}, r\right)=$ mean probability that a random individual in region $r$ becomes infected by inhaling an airborne particle emitted from region $r_{\text {source. }}$. (dimensionless),

[Airborne Infections] $\left(r_{\text {source }}, r\right)=$ total number of people who become infected in region $r$ by inhaling infectious airborne particles emitted from region $r_{\text {source. }}$ (people),

$[$ Area $](r)=$ area of region $r\left(\mathrm{~m}^{2}\right)$,

[Infection Adjustment Factor] $(r)$ = linear scaling factor for region $r$ that accounts for the deviation of exposure and infection response from the reference exposure and infection response (dimensionless),

[Population Density] $(r)=$ population density in region $r\left(\right.$ people $\left.\mathrm{m}^{-2}\right)$,

[Single Particle Infection Probability $]_{r e f}=$ reference probability that an individual will become infected after being exposed to a single particle. This term includes the individual's breathing rate. $\left(\mathrm{m}^{3} \mathrm{~s}^{-1}\right.$ particle $\left.{ }^{-1}\right)$, and

$334[$ Total Particles Released $]=$ total number of particles released into the atmosphere (particles). 
medRxiv preprint doi: https://doi.org/10.1101/2020.04.23.20076273; this version posted April 28, 2020. The copyright holder for this preprint (which was not certified by peer review) is the author/funder, who has granted medRxiv a license to display the preprint in perpetuity. It is made available under a CC-BY-NC-ND 4.0 International license .

M Dillon and C Dillon

Particle Model for Airborne Disease Transmission

\subsection{Relative Infection and Disease Probability}

Although disease outbreak assessments are often based on absolute risks, key outbreak response parameters may not be known. In this setting, relative infection probability metrics can be useful. Equation 3 can also be used to model either relative probabilities of infection or disease. When the source of airborne particles and, separately, the impacted regions are similar (e.g., $r$ and $r_{\text {ref }}$ are both residential areas and $r_{\text {new source }}$ and $r_{\text {ref source }}$ are both office areas), Equation 3 provides the theoretically expected ratio of regional infection probabilities. Note that Equation 3 does not require any information on the release amount per person, the infectivity of individual particles, or the adjustment factor (variation of exposure and population sensitivity). When there is a single source region (i.e., $r_{\text {new source }}=r_{\text {ref source }}$ ), Equation $\mathbf{3}$ allows the infection probability of different downwind regions to be compared. When a clear case of region-to-region airborne disease transmission has been identified, Equation $\mathbf{3}$ could be used to estimate the infection (or disease) rates for new sources and receptor regions. We note that this relative infection/disease probability metric is distinct in form from the traditional "relative risk" metric which is defined as the ratio of infection (or disease) incidence between exposed and baseline (ideally non-exposed) populations.

(Equation 3)

$[$ Relative Infection Probability $](r)=[$ Relative Disease Probability $](r)$

$$
=\frac{[\text { Absolute Airborne Infection Probability }]\left(r_{\text {new source }}, r\right)}{[\text { Absolute Airborne Infection Probability }]\left(r_{\text {ref source }}, r_{\text {ref }}\right)}
$$

$$
=\left(\frac{[\text { Normalized TSIAC }]\left(r_{\text {new source }}, r\right)}{[\text { Normalized TSIAC }]\left(r_{\text {ref source }}, r_{\text {ref }}\right)}\right) \cdot\left(\frac{[\text { Area }]\left(r_{\text {ref }}\right)}{[\text { Area }](r)}\right)
$$

$$
\cdot\left(\frac{[\text { Infectious People }]\left(r_{\text {new source }}\right)}{[\text { Infectious People }]\left(r_{\text {ref source }}\right)}\right)
$$

where

[Infectious People $]\left(r_{\text {source }}\right)=$ number of people emitting infectious particles in source region $r_{\text {source }}$. (people),

[Relative Disease Probability] $(r)=$ ratio of the region $r$ disease probability to reference region $r_{\text {ref }}$ disease probability. (dimensionless), and

[Relative Infection Probability] $(r)=$ ratio of the region $r$ infection probability to reference region $r_{\text {ref }}$ infection probability. (dimensionless). 
medRxiv preprint doi: https://doi.org/10.1101/2020.04.23.20076273; this version posted April 28, 2020. The copyright holder for this preprint (which was not certified by peer review) is the author/funder, who has granted medRxiv a license to display the preprint in perpetuity. It is made available under a CC-BY-NC-ND 4.0 International license .

M Dillon and C Dillon Particle Model for Airborne Disease Transmission

The equations presented in the prior sections and derived in Supplemental Material C: General

364 Theory focus on infection probability. However, not all infections result in disease. In addition, 365 other metrics, such as the probability of needing medical resources or economic impact, may 366 also be of interest. It is straightforward to adapt the prior equations to any metric in which the 367 probability of an individual's response to a single particle exposure can be calculated by 368 multiplying (a) a reference response probability by (b) a linear scaling factor (i.e., a metric 369 specific adjustment factor). While the scaling factor may take any value and may vary by 370 individual, the value for a specific individual cannot change. The adjustment factors can vary by 371 metric. When these conditions are met, the relative incidence, i.e., Equation 3, of multiple 372 metrics of interest, such as infection and disease, are the same. The Equation $\mathbf{3}$ disease spread 373 estimates could also be used to assess importance of other disease transmission pathways for 374 the new receptor region, see Equations 1 and 4.

where

379 [NonAirborne Infections] $(r)=$ number of infected individuals in region $r$ that were infected by the transmission pathways OTHER than airborne. (people), and 
medRxiv preprint doi: https://doi.org/10.1101/2020.04.23.20076273; this version posted April 28, 2020. The copyright holder for this preprint (which was not certified by peer review) is the author/funder, who has granted medRxiv a license to display the preprint in perpetuity.

It is made available under a CC-BY-NC-ND 4.0 International license .

M Dillon and

C Dillon
Particle Model for

Airborne Disease Transmission

\subsection{Indoor Airborne Particle Dynamics}

384 Infectious airborne particles can be emitted within a building. Once airborne, these particles

385 have the potential, among other fates, to (a) be inhaled and infect people within the building or

386 (b) exit the building, enter the outdoor atmosphere, and be transported downwind. To provide 387 context for later discussion, we have extended prior work [30] and derived Equations 5 to 7, 388 which estimate key parameters. ${ }^{7}$ Supplemental Material D: Indoor Particle Dynamics derives 389 these, and other, equations. These equations do not assume, but are compatible with, rare 390 (single particle) exposures.

391

$$
\text { [Building Protection Factor }]=\frac{\left(\lambda_{\text {out }}+\lambda_{\text {internal }}\right)}{\lambda_{\text {in }}}
$$

(Equation 5)

$$
[\text { Normalized TSIAC }]_{\text {indoor }}=\frac{1}{[\text { Room Height }] \cdot\left(\lambda_{\text {out }}+\lambda_{\text {internal }}\right)}
$$

$$
[\text { Building Exit Fraction }]=\frac{\lambda_{\text {out }} \cdot L_{\text {out }}}{\left(\lambda_{\text {out }}+\lambda_{\text {internal }}\right)}
$$

${ }^{7}$ These equations assume that the air within the building is well mixed. As the mixing process takes time and depends on the room/building/population details, exposures (and infection probability) may be higher in the room occupied by an infected individual. We note that within room spread is an area of active research, e.g., [32], but the well-mixed assumption has also been often, but not always, been employed by prior modeling studies that examined indoor bioaerosol dynamics and disease transmission, e.g., [6], [7], [33], [34], and references therein. For context, the mixing time constants for both buoyant and mechanical flow conditions in laboratory studies of room mixing are of order $10 \mathrm{~min}$ to < $1 \mathrm{~h}$ [35], [36]. 
medRxiv preprint doi: https://doi.org/10.1101/2020.04.23.20076273; this version posted April 28, 2020. The copyright holder for this preprint

(which was not certified by peer review) is the author/funder, who has granted medRxiv a license to display the preprint in perpetuity.

It is made available under a CC-BY-NC-ND 4.0 International license .

M Dillon and

C Dillon
Particle Model for

Airborne Disease Transmission

where

$401 \quad \lambda_{\text {in }}=$ the rate at which outdoor airborne particles enter the building - typically via infiltration or ventilation. Includes losses that occur during transport from outdoor to indoor. $\left(\mathrm{h}^{-1}\right)$,

$403 \quad \lambda_{\text {internal }}=$ the rate at which indoor particles are lost within the building. This term includes both physical

404 losses, such as deposition to indoor surfaces, and infectivity losses while the particle is airborne $\left(\mathrm{h}^{-1}\right)$,

$405 \lambda_{\text {out }}=$ the rate at which indoor particles exit the building. $\left(\mathrm{h}^{-1}\right)$,

406 [Building Exit Fraction] = fraction of material released within a building that exits the building and enters 407 the outdoor atmosphere. (no units),

408 [Building Protection Factor] = ratio of the outdoor to indoor exposure. Similar to sunscreen and personal 409 protective respirator rating systems, higher protection factor values indicate lower exposures and 410 thus increased protection. (protection factor),

$411 L_{\text {out }}$ (particle size $)=$ the fraction of indoor particles lost while exiting the building. (dimensionless),

412 [Normalized TSIAC $]_{\text {indoor }}=$ indoor time and space integrated air concentration assuming a single particle $413 \quad$ is released. $\left(\mathrm{s} \mathrm{m}^{-1}\right)$, and

414 [Room Height] $=$ height of building living space. $(\mathrm{m})$. 
medRxiv preprint doi: https://doi.org/10.1101/2020.04.23.20076273; this version posted April 28, 2020. The copyright holder for this preprint (which was not certified by peer review) is the author/funder, who has granted medRxiv a license to display the preprint in perpetuity. It is made available under a CC-BY-NC-ND 4.0 International license .

M Dillon and

C Dillon
Particle Model for Airborne Disease Transmission

\section{Results}

417 This section applies the previously derived theory to estimate regional-level metric values. First,

418 upper bound estimates are provided for both individual person level and regional level

419 infection probabilities for locations downwind. These results assume that infectious particles

420 are emitted from a single, non-moving source. ${ }^{8}$ Second, the relative infection and disease

421 probabilities as a function of downwind distances are provided. The modeling examples

422 provided here (a) assume $1 \mu \mathrm{m}$ AD particles and no airborne loss of infectivity and (b) consider

423 a wide range of common weather conditions. ${ }^{9}$ Other scenarios, including those with varying

424 particle and environmental parameters, are briefly discussed for context. Third, the relative

425 importance of within building and downwind (both indoors and outdoors) infections is

426 illustrated.

427 In this section we also compare the modeled predictions for relative infection probabilities

428 (Equation 3), with existing observational data from disease outbreaks which have a major

429 airborne transmission pathway. This is not a formal theory validation but is a useful initial

430 assessment of theory predictions compared to data from real-world events. As the primary data

431 collected by the investigators were not available, existing data were abstracted from journal

432 article tables and figures, see Supplemental Material F: Outbreak Model-Measurement

433 Comparison. The scope and detail of the published observational data varied between studies

434 which limited the comparisons. In general, the outbreak disease case ascertainment method was notified clinical cases (passive surveillance) and so a fraction of diagnosed cases and any undiagnosed cases were missed. Detailed sub-regional population demographics were not

437 presented, and so adjusted age-specific disease incidence rates could not be estimated. Disc-

438 specific disease incidence rates were not available in some studies. Also, true background

439 disease incidence rates were not reported. Multiple transmission pathways are common in

440 infectious diseases. Most of these studies evaluated that possibility, but one study did not [37].

441 All studies showed a clear pattern of high disease incidence rates close to an exposure source

442 with a rapid decrease in disease incidence with increasing distance thereafter. Figure 4

443 demonstrates this behavior using the Q Fever data. This attack rates shown in Figure 4 likely

444 underestimate the actual values, see the 5.2. Background Disease Incidence section below.

${ }^{8}$ This is an assumption used to simplify the analysis presented in this report. Methodology exists for modeling mobile populations that is compatible with RSA analysis, see the 5.4 Potential Future Efforts section and reference [31].

${ }^{9} 1 \mu \mathrm{m}$ AD particles are chosen here for theoretical modeling purposes. However, this particle size is characteristic of many infectious bacterial cells. Furthermore, infectious agents, including viruses, may be carried on, or in, larger particles comprised of other material such as respiratory fluids, see the 5.3.2. Single Particle Infectivity section. 
medRxiv preprint doi: https://doi.org/10.1101/2020.04.23.20076273; this version posted April 28, 2020. The copyright holder for this preprint (which was not certified by peer review) is the author/funder, who has granted medRxiv a license to display the preprint in perpetuity. It is made available under a CC-BY-NC-ND 4.0 International license .

M Dillon and

C Dillon
Particle Model for Airborne Disease Transmission
445

446

447

448

449

Figure 4. Observed Q Fever attack rate as a function of distance as published in airborne infectious disease outbreak studies. The distance downwind corresponds to the radial distance from the source to the center of a circular band (torus) centered on the source. The band width varies with each point and ranges from $50 \mathrm{~m}$ to $5 \mathrm{~km}$. The legend shows the study location, outbreak year, and infectious agent $(Q=Q$ Fever (Coxiella burnetti)).

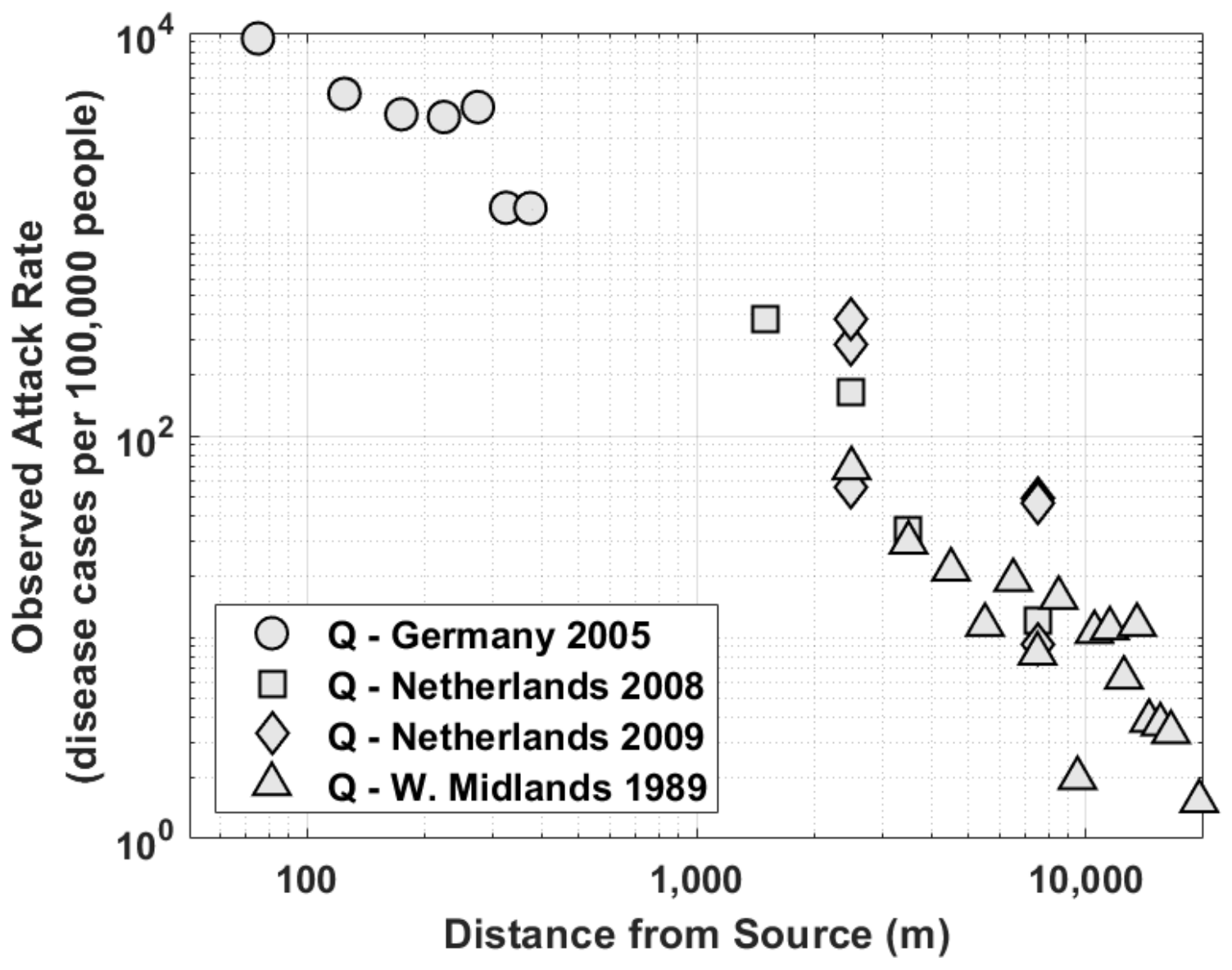


medRxiv preprint doi: https://doi.org/10.1101/2020.04.23.20076273; this version posted April 28, 2020. The copyright holder for this preprint (which was not certified by peer review) is the author/funder, who has granted medRxiv a license to display the preprint in perpetuity. It is made available under a CC-BY-NC-ND 4.0 International license .

M Dillon and C Dillon Particle Model for Airborne Disease Transmission

\subsection{Upper Bound on Absolute Infection Probability vs. Distance}

453 The top panels in Figure 5(a-b) show the predicted upper bound on the absolute airborne

454 infection probability for each particle released to the outdoor atmosphere as integrated (a)

455 over a series of discs and (b) along a series of circle arcs (see Figure 2) at distances between 50

$456 \mathrm{~m}$ and $20 \mathrm{~km}$ from the release point. The bottom panels show the corresponding number of

457 infections in an urban area (assuming 0.01 people $\mathrm{m}^{-2}$ ) for each airborne particle released. For

458 context, about 30\% of the New York State, US 2000 Census Tracts have population densities $\geq$

4590.01 people $\mathrm{m}^{-2}$.

460 The results shown in Figure 5 were derived from Equations 1 and $\mathbf{2}$ and Table E2 from

461 Supplemental Material E: Outdoor Normalized Time and Space Integrated Air Concentrations.

462 We present here the results for one important class of possible weather scenarios, where 463 constant light, moderate, and strong winds (1, 4.5, and $10 \mathrm{~m} \mathrm{~s}^{-1}$, respectively) would transport 464 an airborne particle $1 \mathrm{~km}$ downwind in about 17, 4, and $2 \mathrm{~min}$, respectively. ${ }^{10}$ Thus these results 465 are reasonable when losses are not significant on the timescale of minutes to hours. ${ }^{11}$

466 The absolute infection probability varies over several orders of magnitude and decreases 467 rapidly with distance. Broadly speaking, the infection probability increases with (i) decreasing 468 wind speed and (ii) increasing atmospheric stability (increasing stability corresponds to 469 decreasing rates at which material dilutes within the broader atmosphere). The actual infection 470 probability will be smaller if not all inhaled particles cause infections and/or the individual is 471 indoors or otherwise protected. In the latter case, downwind infection probability estimates 472 can be determined by dividing the values shown in Figure 5 by a building protection factor, e.g., 473 [30]. We note that the expected number of infections linearly scales with both the total number 474 of particles released and the population density.

475 When the airborne loss rate is significant on the timescale of minutes, e.g., $10 \mathrm{~h}^{-1}$, the modeled 476 relative infection incidence increases with wind speed at distances greater than $1 \mathrm{~km}$, see

477 Figure 6.

${ }^{10}$ This transport timescale calculation is intended for illustrative purposes as it does not consider the effects of atmospheric turbulence (e.g., plume dispersion) nor the known increase of wind speed with height above the earth's surface.

${ }^{11}$ For context, respirable size ( 1 to $5 \mu \mathrm{m} A D$ ) particle deposition losses are often limited (approximately $0.1 \mathrm{~h}^{-1}$ or less) on these scales. Deposition rates depends on particle size, atmospheric conditions, and surface characteristics. For this illustrative calculation, we have assumed (a) a $1 \mathrm{~cm} \mathrm{~s}^{-1}$ deposition velocity (the speed at which the particle travels to a surface and is lost) [38], (b) a $300 \mathrm{~m}$ boundary layer height (the height of the air near the surface that is well mixed - this value corresponds to stable, nighttime conditions), and (c) that the atmospheric boundary layer is a wellmixed system and so the deposition loss rate = deposition velocity / boundary layer height [39]. 
medRxiv preprint doi: https://doi.org/10.1101/2020.04.23.20076273; this version posted April 28, 2020. The copyright holder for this preprint (which was not certified by peer review) is the author/funder, who has granted medRxiv a license to display the preprint in perpetuity. It is made available under a CC-BY-NC-ND 4.0 International license.

M Dillon and

C Dillon
Particle Model for

Airborne Disease Transmission
478

479

480

481

482

483

Figure 5. Predicted infection probabilities and infections by distance, wind speed and atmospheric stability for a single airborne particle with no airborne loss of infectivity. Legend box indicates Pasquill-Gifford-Turner atmospheric stability class ( $A$ to $F$ ) and the $10 \mathrm{~m}$ agl wind speed. Individual person infection probability (top panels) is dimensionless. Urban area infections (bottom panels) assume a uniform population density of 0.01 people $\mathrm{m}^{-2}$ and has dimensions of people (disc) or people $\mathrm{m}^{-1}$ (arc).

Figure 5a. Infection Probabilities and Urban Infections Within a Disc Centered on the Release
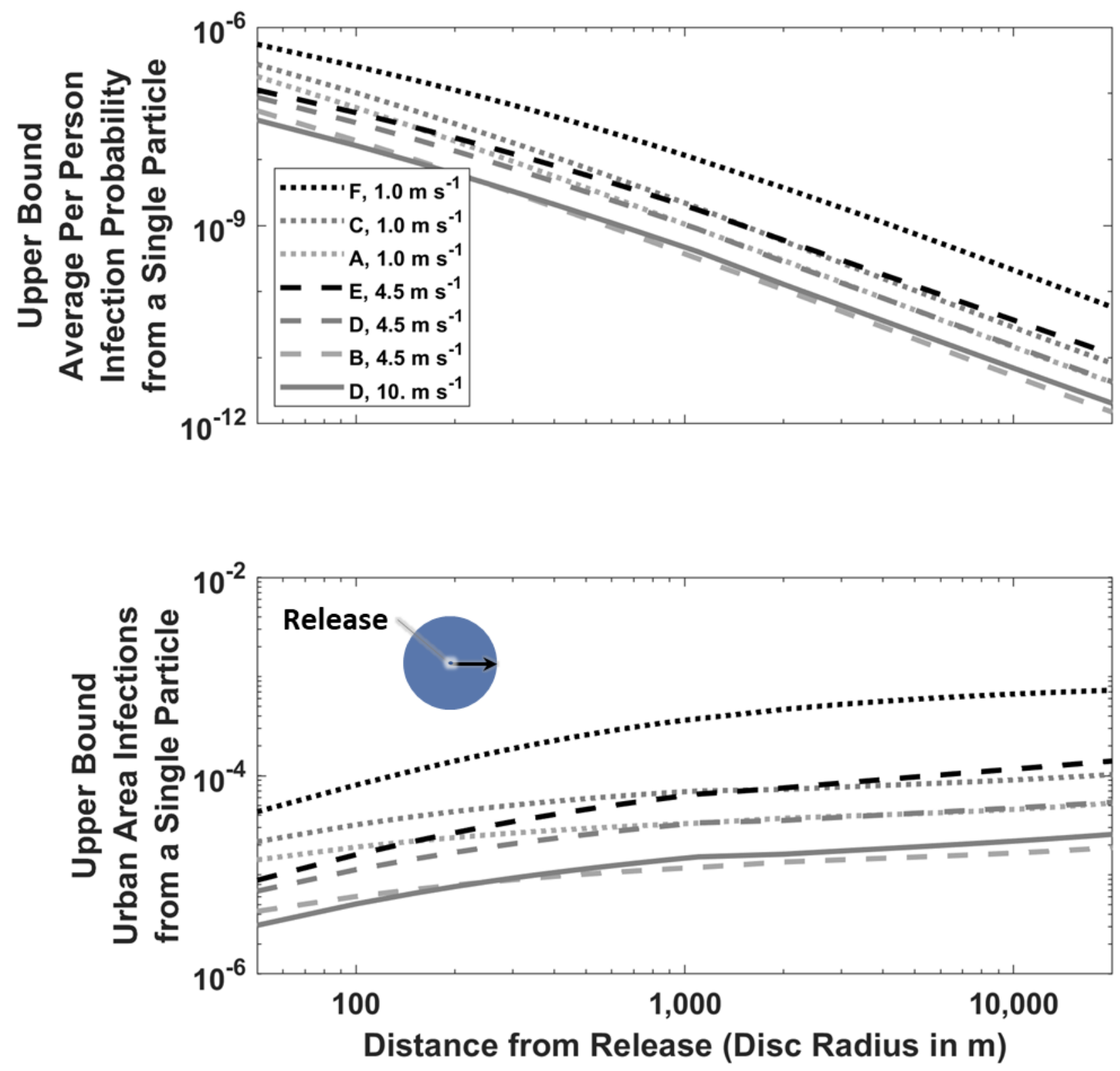
medRxiv preprint doi: https://doi.org/10.1101/2020.04.23.20076273; this version posted April 28, 2020. The copyright holder for this preprint (which was not certified by peer review) is the author/funder, who has granted medRxiv a license to display the preprint in perpetuity. It is made available under a CC-BY-NC-ND 4.0 International license .

M Dillon and C Dillon
Particle Model for Airborne Disease Transmission

Figure 5b. Infection Probabilities and Urban Infections Along an Arc Centered on the Release
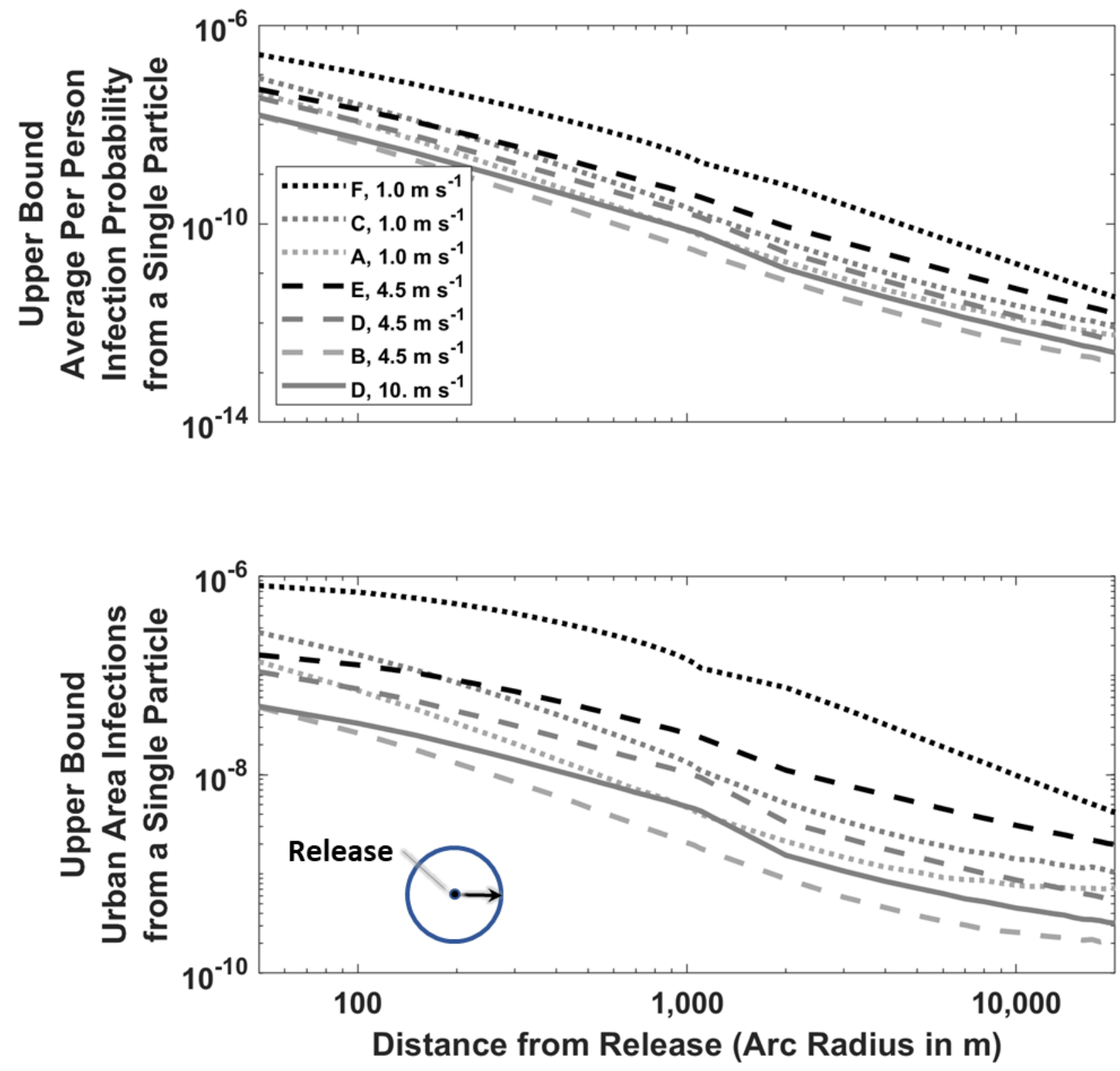
medRxiv preprint doi: https://doi.org/10.1101/2020.04.23.20076273; this version posted April 28, 2020. The copyright holder for this preprint (which was not certified by peer review) is the author/funder, who has granted medRxiv a license to display the preprint in perpetuity. It is made available under a CC-BY-NC-ND 4.0 International license .

M Dillon and

C Dillon
Particle Model for

Airborne Disease Transmission
488

489

490

491

492

493

Figure 6. Predicted infection probabilities and infections by distance, wind speed and atmospheric stability for a single airborne particle with a $10 \mathrm{~h}^{-1}$ airborne loss of infectivity. Legend box indicates Pasquill-Gifford-Turner atmospheric stability class ( $A$ to $F$ ) and the $10 \mathrm{~m}$ agl wind speed. Individual person infection probability (top panels) is dimensionless. Urban area infections (bottom panels) assume a uniform population density of 0.01 people $\mathrm{m}^{-2}$ and has dimensions of people (disc) or people $\mathrm{m}^{-1}(\operatorname{arc})$.

Figure 6. Infection Probabilities and Urban Infections Along an Arc Centered on the Release
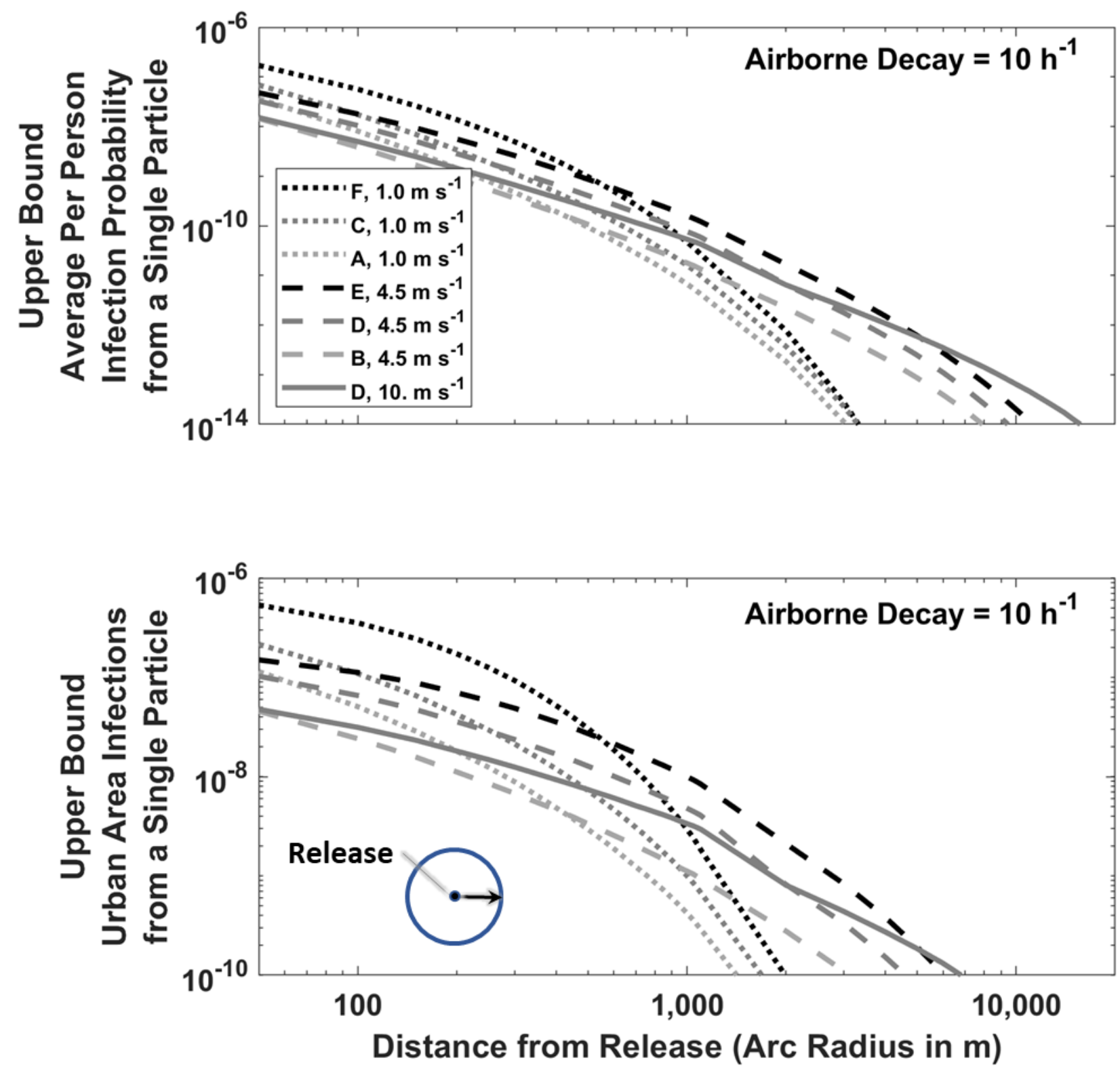
medRxiv preprint doi: https://doi.org/10.1101/2020.04.23.20076273; this version posted April 28, 2020. The copyright holder for this preprint (which was not certified by peer review) is the author/funder, who has granted medRxiv a license to display the preprint in perpetuity. It is made available under a CC-BY-NC-ND 4.0 International license .

M Dillon and C Dillon
Particle Model for Airborne Disease Transmission

\subsection{Relative Infection and Disease Probability vs. Distance}

496 Figure 7a shows the corresponding relative infection (and disease) probabilities as calculated by

497 Equation $\mathbf{3}$ and the upper bound absolute infection probability curves shown in Figure $\mathbf{5}$ as

498 integrated over (top panel) a disc and (bottom panel) along a circle arc, both being centered at

499 the common release point $\left(r_{\text {new source }}=r_{\text {ref source }}\right)$. While the relative infection (and disease)

500 probabilities again decrease rapidly with distance, there is minimal variation with wind speed or

501 atmospheric stability over the range of atmospheric conditions considered. ${ }^{12}$ Hence the relative

502 infection probability metric may be particularly valuable when there is incomplete or entirely

503 lacking information on meteorological conditions, but (a) atmospheric conditions are known to

504 not be materially changing during the time it takes for the infectious particles to travel from the

505 source to the receptor and (b) the particle infectivity is not lost rapidly in the atmosphere. This

506 relationship is expected to hold even when the exposed population has varying sensitivity to the

507 infecting particle and/or are located inside buildings affording different degrees of protection as

508 long as the distributions of both the infection sensitivity and building protection are similar in

509 both exposure regions.

510 When the airborne loss rate is significant on the timescale of minutes, e.g., $10 \mathrm{~h}^{-1}$, the modeled

511 relative infection incidence for circle arcs increases with wind speed, see Figure $7 \mathbf{b}$. Notably,

512 the slope of $\log _{10}$ (distance from source) vs. $\log _{10}$ (relative infection rate) is smaller than the no (0

$513 \mathrm{~h}^{-1}$ ) airborne loss rate case. Due to the rapid decrease in airborne infection probability with

514 distance, the corresponding plots for relative infection incidence for a disc are nearly identical

515 to that shown in Figure 7a.

${ }^{12}$ The equations shown in Figure 7 are based on the mean of the individual slope and intercept for each weather case $\left(r^{2}>0.99\right.$ for all cases). The individual values varied less than $15 \%$ from the mean values provided. 
medRxiv preprint doi: https://doi.org/10.1101/2020.04.23.20076273; this version posted April 28, 2020. The copyright holder for this preprint (which was not certified by peer review) is the author/funder, who has granted medRxiv a license to display the preprint in perpetuity. It is made available under a CC-BY-NC-ND 4.0 International license .

M Dillon and

C Dillon
Particle Model for

Airborne Disease Transmission
517

518

519

520

Figure 7. Predicted relative infection probabilities by distance, wind speed and atmospheric stability for a single airborne particle with (a) $0 \mathrm{~h}^{-1}$ and (b) $10 \mathrm{~h}^{-1}$ airborne infectivity loss rates. Legend box indicates Pasquill-Gifford-Turner atmospheric stability class ( $A$ to $F$ ) and the $10 \mathrm{~m}$ agl wind speed. Relative infection probability is dimensionless.

Figure 7a. Relative Infection Probabilities as a Function of Distance from Release
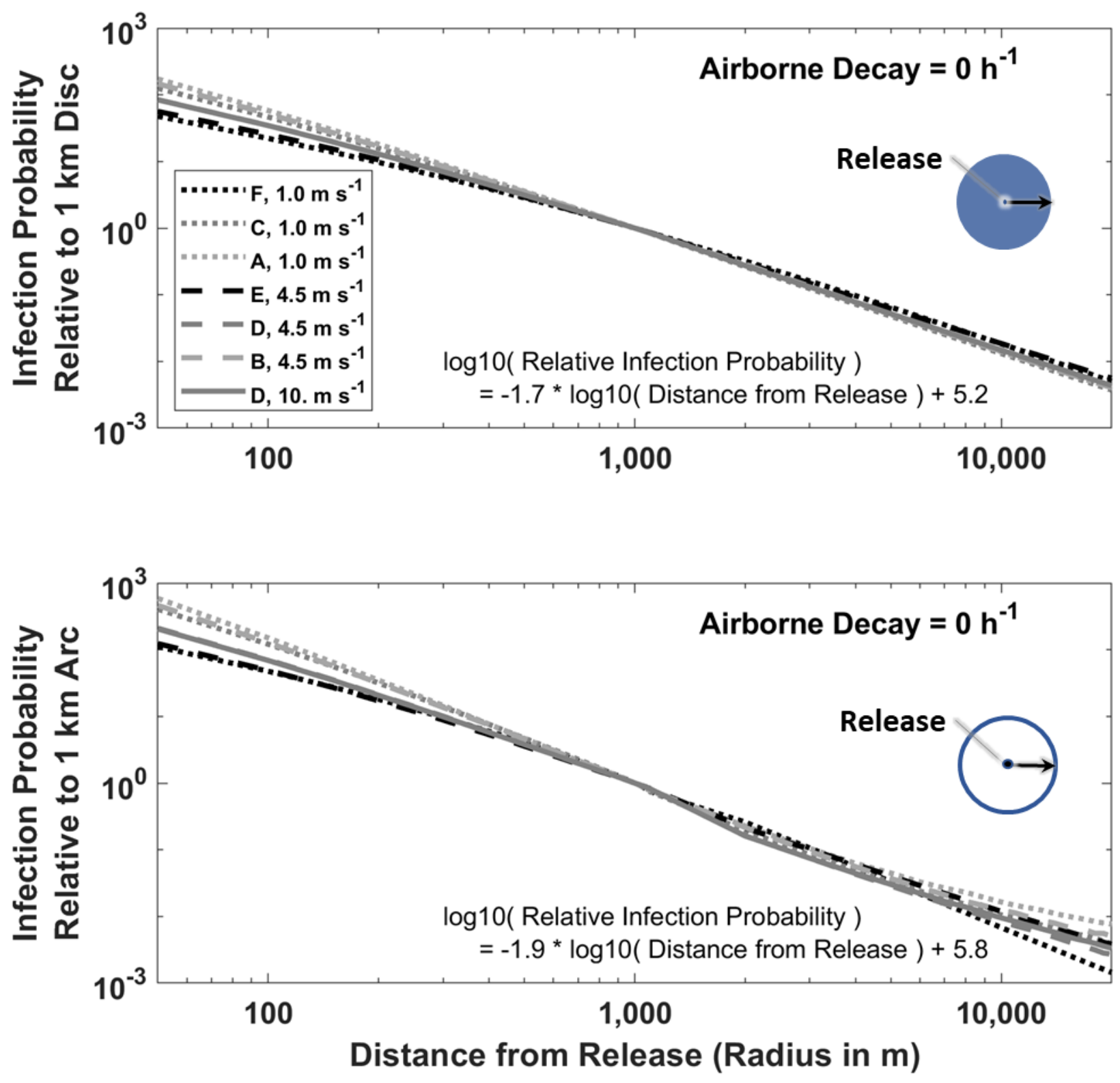
medRxiv preprint doi: https://doi.org/10.1101/2020.04.23.20076273; this version posted April 28, 2020. The copyright holder for this preprint (which was not certified by peer review) is the author/funder, who has granted medRxiv a license to display the preprint in perpetuity. It is made available under a CC-BY-NC-ND 4.0 International license .

M Dillon and C Dillon
Particle Model for

Airborne Disease Transmission

Figure 7b. Relative Infection Probabilities as a Function of Distance from Release
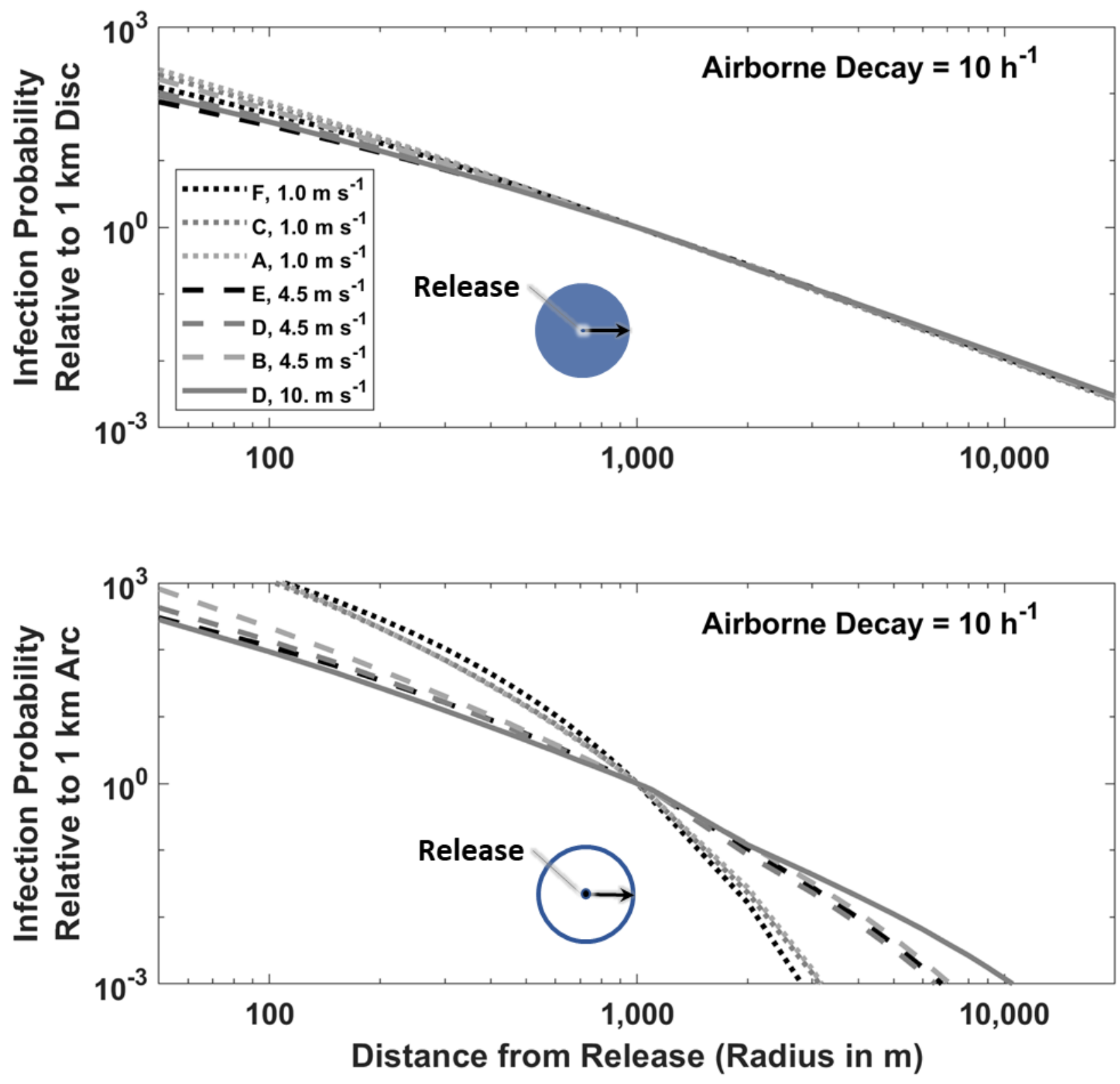
medRxiv preprint doi: https://doi.org/10.1101/2020.04.23.20076273; this version posted April 28, 2020. The copyright holder for this preprint (which was not certified by peer review) is the author/funder, who has granted medRxiv a license to display the preprint in perpetuity. It is made available under a CC-BY-NC-ND 4.0 International license .

M Dillon and C Dillon

Particle Model for Airborne Disease Transmission

\subsection{Model Prediction - Outbreak Data Comparison}

526 In this section, we compare previously published, major airborne outbreak data against relative

527 probability values calculated using Equation 3. First we use data from Q Fever (Coxiella

528 burnetti) [37], [40]-[42], Legionnaire's disease (Legionella pneumophilia) [43], [44], and Valley

529 Fever (Coccidioides immitis) [45], [46] outbreaks. We note that these human pathogens have

530 reproductive number $\left(R_{0}\right)$ values less than 1 (Case 1 diseases) and so they have little or no

531 potential for person-to-person transmission, simplifying the airborne disease modeling. ${ }^{13}$

532 Subsequently we use results derived from veterinary disease outbreak studies of Highly

533 Pathogenic Avian influenza (HPAI) [47]-[49], Foot and Mouth Disease (FMD) [50], [51], and

534 Classical Swine Fever (CSF) [52]. These diseases have reproductive numbers ( $\left.\mathrm{R}_{0}\right)$ greater than 1

535 (Case 2 diseases) and so have the potential for secondary epidemic spread (they also are known

536 to have multiple disease transmission pathways). The modeled values were determined using

537 Equation 3 and the neutral (D) stability, moderate wind ( $4.5 \mathrm{~m} \mathrm{~s}^{-1}$ at $10 \mathrm{~m}$ agl) modeling results

538 presented in Supplemental Material E: Outdoor Normalized Time and Space Integrated Air

539 Concentrations. Other than the source location, definition of the base and reference areas, and

540 the assumption of a single source $\left(r_{\text {new source }}=r_{\text {ref source }}\right)$, no disease or outbreak specific

541 information was used in the modelling.

542 Figure 8 compares the predicted model relative disease probabilities to the observed relative

543 incidence of clinical disease reported for Q Fever, Legionnaire's disease, and Valley Fever

544 outbreaks. The modeled and measured values are reasonably well correlated, $r^{2}=0.86$, and

545 close to the 1:1 line. ${ }^{14}$ The base and reference areas vary by comparison point and are specified

546 in Supplemental Material F: Outbreak Model-Measurement Comparison. Some data points

547 from these studies were not used either due to (a) the low number of observed disease cases ${ }^{15}$

548 or (b) because they were adjacent to the source and did not exhibit the expected decrease in

549 disease rate with distance. The specific data points used and omitted are indicated in the

550 Supplemental Material F: Outbreak Model-Measurement Comparison.

${ }^{13}$ This case is also applicable to initial stage of epidemic that is later propagated by secondary transmission.

${ }^{14} \mathrm{~A}$ linear regression (not shown) of the data presented in Figure 8 yields $\log _{10}$ (Modeled Relative Disease Probability) $=1.05( \pm 0.08) * \log _{10}$ (Observed Relative Disease Incidence) $-0.10( \pm 0.05)$. A linear regression with all available data reduces the correlation, $\mathrm{r}^{2}=0.53$, but yields a similar line, $\log _{10}$ (Modeled Relative Disease Probability) $=0.85( \pm 0.13) * \log _{10}$ (Observed Relative Disease Incidence) - 0.02 ( \pm 0.09 ). The provided parameter uncertainties are $\pm 1 \sigma$.

${ }^{15}$ As a practical matter, the population within the region of interest may be low and so the corresponding disease incidence rates may be unreliable. 
medRxiv preprint doi: https://doi.org/10.1101/2020.04.23.20076273; this version posted April 28, 2020. The copyright holder for this preprint (which was not certified by peer review) is the author/funder, who has granted medRxiv a license to display the preprint in perpetuity. It is made available under a CC-BY-NC-ND 4.0 International license .

M Dillon and C Dillon
Particle Model for

Airborne Disease Transmission
551

552

553

554

555

556

\section{Figure 8. Modeled Relative Disease Probability Compared to Observed Relative Disease} Incidence as published in airborne infectious disease outbreak studies. The dashed line is the 1:1 line which indicates perfect agreement. The legend box shows the study location, outbreak year, and infectious agent $(Q=Q$ Fever (Coxiella burnetti); $L=$ Legionnaire's Disease (Legionella); C = Valley Fever (Coccioidomycosis)).

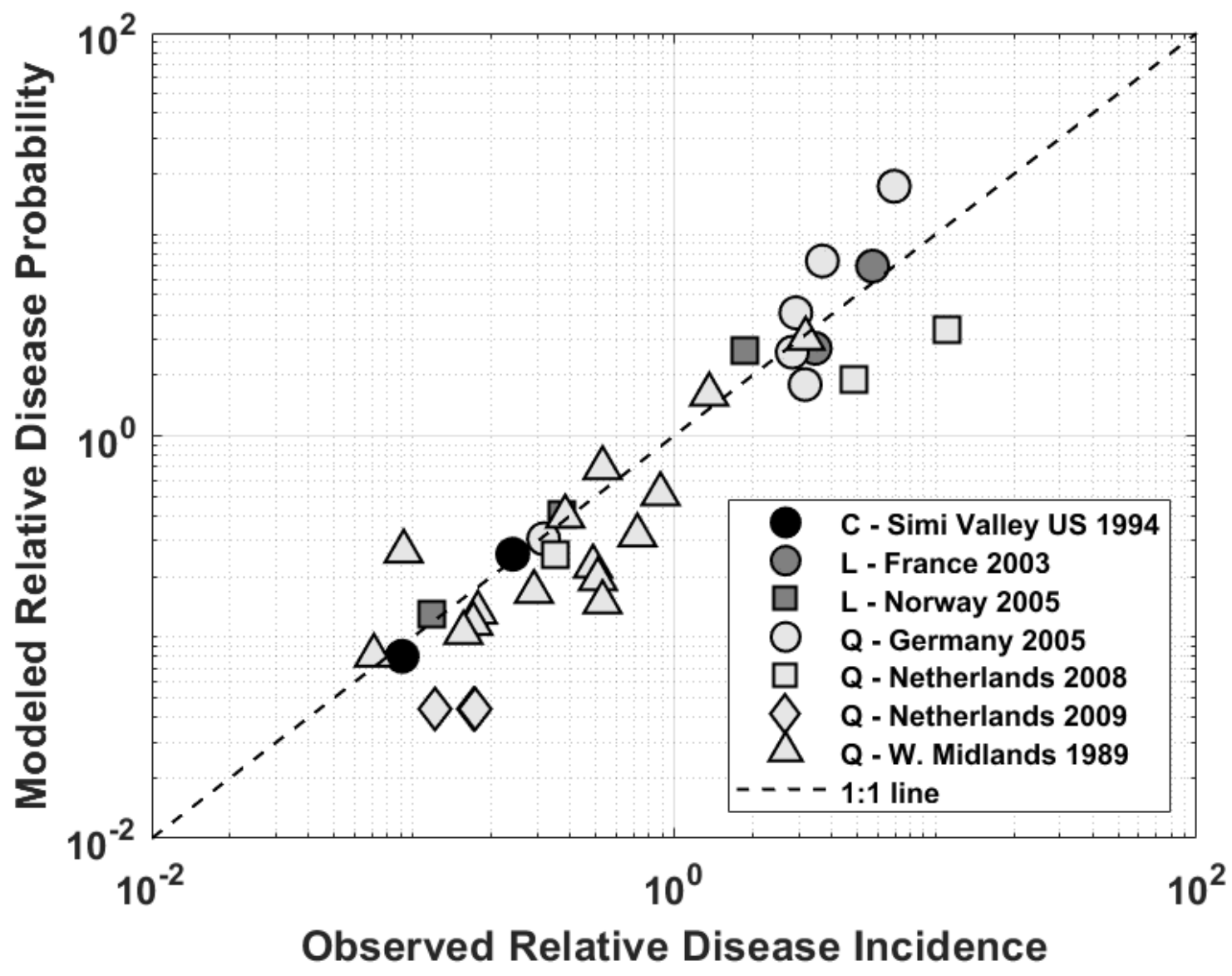


medRxiv preprint doi: https://doi.org/10.1101/2020.04.23.20076273; this version posted April 28, 2020. The copyright holder for this preprint (which was not certified by peer review) is the author/funder, who has granted medRxiv a license to display the preprint in perpetuity. It is made available under a CC-BY-NC-ND 4.0 International license .

M Dillon and C Dillon Particle Model for Airborne Disease Transmission

Table 2 demonstrates that our prediction ${ }^{16}$ of the slope of $\log _{10}$ (distance from source) vs. $\log _{10}$ (relative infection rate) $\leq-2$ is consistent with both (a) the previously discussed studies and (b) as previously reported for Highly Pathogenic Avian influenza and Foot and Mouth Disease outbreaks. We note that Classical Swine Fever and Valley Fever do not have sufficient data to formally assess this statement, but the reported values are $\pm 25 \%$ of the predicted values.

For the HPAI, FMD, and CSF cases, the infection rate as a function of distance was determined by the original authors from a set of base equations whose parameter values were determined from the timing of the discovery of each specific disease case, the locations of known infected farms, assumptions about disease incubation periods, the time from infection until detection, certain farm attributes, and (for some studies) varying sensitivity to a given infectious exposure. In contrast to the current analysis, the analyses presented in those studies did not model the physics of disease transmission mechanisms, nor do they assume airborne transmission. In these outbreaks, the infection probability (transmission kernel) was demonstrated to be relatively constant over an initial, short-range geographic extent and then decrease with distance. The latter decrease in infection probability (disease incidence rate) with distance is equivalent to the slope in equation shown in lower panels of both Figure $7(\mathbf{a}-\mathbf{b}) .{ }^{17}$

The observed FMD disease rate decreases notably faster than that demonstrated in our baseline results, which assume no atmospheric loss of infectivity. The FMD results are, however, more consistent with modeling that includes infectivity losses that are significant on the timescale of the plume transport and we note that FMD virus is in fact known to lose infectivity in the atmosphere [53].

${ }^{16}$ We speculate, but have not proven, that this result is related to the well-known fact that away from the source, airborne plume dispersion is proportional to (distance) $)^{1 / 2}$, see Supplemental Material B: Key Atmospheric Transport and Dispersion Modeling Concepts. If true, then we would expect that the slope of $\log _{10}$ (distance from source) vs. $\log _{10}$ (relative infection rate) would be closer to -1 for impacts that take place close to the source, where dispersion eddies are well-correlated and the airborne plume dispersion is proportional to distance.

${ }^{17}$ (a) This statement is true in the mathematical limit that the "base" and "reference" distance in the prior study equations are large relative to the constant infectivity distance, (b) The modeling presented in this study is limited to less than $20 \mathrm{~km}$ from the source. 
medRxiv preprint doi: https://doi.org/10.1101/2020.04.23.20076273; this version posted April 28, 2020. The copyright holder for this preprint (which was not certified by peer review) is the author/funder, who has granted medRxiv a license to display the preprint in perpetuity.

It is made available under a CC-BY-NC-ND 4.0 International license .

M Dillon and

C Dillon

Particle Model for

Airborne Disease Transmission

580

Table 2. Summary of decrease in relative infectivity (or disease) with distance for selected

581 studies.

$\begin{array}{cc} & \text { Decrease in } \\ \text { Relative } \\ \text { Infectivity (or } \\ \text { Disease) } \\ \text { Oncidence } \\ \text { with Distance }\end{array}$

\author{
Uncertainty / \\ Variability \\ Reference
}

with Distance

model prediction for $1 \mu \mathrm{m}$ aerodynamic diameter particles and no atmospheric losses

$\mathrm{n} / \mathrm{a}$

$-1.9$

-1.7 to $-1.9^{\text {a }}$

(this study)

analysis of prior studies shown in Figure $8^{b}$

\begin{tabular}{cccc}
\hline & \multicolumn{2}{c}{ Q Fever (Coxiella burnetti) } & \\
Netherlands 2008 & -2.2 & -1.8 to $-2.5^{c}$ & {$[40]$} \\
W. Midlands 1989 & -1.5 & -0.9 to $-2.0^{c}$ & {$[42]$} \\
Germany 2005 & -1.4 & -0.17 to $-2.7^{\mathrm{c}}$ & {$[37]$} \\
\hline & Legionnaire's Disease (Legionella) & \\
Norway 2005 & -1.5 & -1.3 to $-1.8^{\mathrm{c}}$ & {$[43]$} \\
France 2003 & -0.7 & $\mathrm{n} / \mathrm{a}$ & {$[44]$} \\
\hline
\end{tabular}

Valley Fever (Coccioidomycosis)

\begin{tabular}{cccc} 
Simi Valley 1994 & -1.4 & n/a & [45], [46] \\
\hline \multicolumn{4}{c}{ other prior studies $^{\mathrm{d}}$} \\
\hline Highly Pathogenic Avian Influenza (HPAI) \\
Netherlands 2003 & -2.1 & -1.8 to $-2.4^{\mathrm{c}}$ & [47] \\
Minnesota 2015 (first wave) & -2.4 & -1.7 to $-3.7^{\mathrm{c}}$ & [48] \\
Italy 2000 & -2.1 & -1.9 to $-2.3^{\mathrm{c}}$ & [49] (reported in [48]) \\
\hline
\end{tabular}

Foot and Mouth Disease (FMD)

\begin{tabular}{cccc} 
Japan 2010 & -2.5 & $\mathrm{n} / \mathrm{a}$ & [50] \\
Great Britain 2001 & -2.7 & -2.6 to $-2.8^{\mathrm{c}}$ & [51] \\
(conditioned on Feb 23 data) & -7 & . \\
\hline
\end{tabular}

Classical Swine Fever (CSF)

Netherlands 1997/1998 $\quad-2.2 \quad$ n/a

582

583 a range modeled

$584{ }^{\mathrm{b}}$ slope of $\log _{10}$ (distance in $\mathrm{m}$ ) vs. $\log _{10}$ (relative disease rate) calculated for this study

585 c $95 \%$ Confidence Interval

$586{ }^{d}$ as reported in referenced study

587 
medRxiv preprint doi: https://doi.org/10.1101/2020.04.23.20076273; this version posted April 28, 2020. The copyright holder for this preprint (which was not certified by peer review) is the author/funder, who has granted medRxiv a license to display the preprint in perpetuity. It is made available under a CC-BY-NC-ND 4.0 International license .

M Dillon and C Dillon
Particle Model for Airborne Disease Transmission

\subsection{Relative Magnitude of Within Building and Downwind Infections}

589 Physical science considerations suggest that some fraction of airborne indoor particles will exit

590 buildings. For example, we predict that, on average, about 35\% of the airborne, $0 \mathrm{hr}^{-1}$ infectivity

591 loss rate, $1 \mu \mathrm{m}$ particles in US single family homes will be released to the outdoor atmosphere,

592 see Supplemental Material D: Indoor Particle Dynamics and [30]. ${ }^{18}$ Indeed under some

593 conditions, infections due to airborne transmission could result in similar numbers of people

594 being infected downwind than in the same house as an infected individual - see the example

595 provided in Supplemental Material G: Infection Estimates. When the regional population

596 density is notably greater than 0.01 people $\mathrm{m}^{-2}$, more people may be infected downwind than

597 within the source building. We note that (a) not all diseases are capable of longer-distance

598 downwind transmission, see 5.3. Key Infectious Agent/Disease Characteristics section, (b) other

599 disease transmission pathways may substantially increase the probability of being infected

600 while sharing the same house as an infected individual, (c) downwind individuals may be

601 indoors, and (d) even for the airborne transmission pathway, the "per-person" infection

602 probability is higher within a given building than it is downwind.

603 Building operation changes could alter the absolute and relative probability of source building 604 and downwind infections. For example, actions that increase the indoor/outdoor air change 605 rates $\left(\lambda_{\text {out }}, \lambda_{\text {in }}\right)$, such as increasing the ventilation, would (a) decrease indoor exposures within 606 the source building, (b) increase the number of infectious particles emitted to the greater 607 atmosphere, and (c) decrease the protection downwind buildings provide their occupants. In 608 contrast, actions that increase the within building loss rates $\left(\lambda_{\text {internal }}\right)$, potentially including 609 replacement of existing furnace filters with higher efficiency filters, have the potential to 610 reduce exposures in both the source and downwind buildings.

\footnotetext{
${ }^{18}$ This fraction is expected to vary with particle size, airborne infectivity loss rate, and building type.
} 
medRxiv preprint doi: https://doi.org/10.1101/2020.04.23.20076273; this version posted April 28, 2020. The copyright holder for this preprint (which was not certified by peer review) is the author/funder, who has granted medRxiv a license to display the preprint in perpetuity. It is made available under a CC-BY-NC-ND 4.0 International license .

M Dillon and

C Dillon
Particle Model for Airborne Disease Transmission

\section{Discussion}

\section{5.1. Characterizing Airborne Disease Spread}

614 In a disease outbreak situation, it may be necessary to establish whether airborne disease 615 transmission is occurring. Laboratory studies to identify the suspect pathogen and the known 616 pathogen characteristics (see the 5.3. Key Infectious Agent/Disease Characteristics section 617 above) are valuable in this regard. Epidemiological factors may indicate a spatio-temporal signal 618 consistent with airborne transmission, specifically (a) new infections that have no contact with 619 a known infectious individual, (b) correlation between new infections and key weather conditions, and (c) the presence of disease "sparks" outside the regions of known infection. This work suggests an additional method, where the geographic distribution of observed disease

622 cases agrees with that predicted by Equation 3, i.e., log10(distance from source) vs.

$623 \log 10$ (disease rate) is linear with a slope $\leq-2$. Comparison to prior outbreak data suggests that

624 this airborne transmission signal may be readily apparent, especially in cases where there is a

625 single emission source. However, we note that it could be (a) mimicked by other infection

626 transmission pathways if they are also correlated with distance from the source, (b) obscured

627 by other disease transmission pathways, and (c) challenging to identify when there are

628 multiple, geographically separate emission source regions. However, other disease transmission

629 pathway(s) should be considered when the Equation 3 predicted signal is absent.

630

631

632

633

634

635

636

637

638

639

640

641

642

643
The theory and modeling presented in this paper define the single particle airborne disease transmission kernel. This kernel corresponds to the set of lower probability, longer-distance airborne transmission events. These could contribute to large scale disease spread by "sparking" unexpected disease outbreaks distant from an emission source. The impacts of these longer-distance transmissions can be high for diseases that can cause many secondary infections (i.e., Case 2 diseases). In the plant biology and biosafety literature, it is well understood that these low probability, long distance (100's of km) spread events do occur and are a primary mechanism of long-term species colonization of new environments and plant pathogen spread [54]-[57]. Indeed, unexpected long-distance disease sparks are a particularly well-documented problem in Foot and Mouth Disease of ruminants, where prior investigators have noted "Airborne spread is the most important mechanism of uncontrollable [disease] spread and although this is not a common event, when it occurs the speed and extent of spread can be spectacular" [58]. 
medRxiv preprint doi: https://doi.org/10.1101/2020.04.23.20076273; this version posted April 28, 2020. The copyright holder for this preprint (which was not certified by peer review) is the author/funder, who has granted medRxiv a license to display the preprint in perpetuity. It is made available under a CC-BY-NC-ND 4.0 International license .

M Dillon and

C Dillon
Particle Model for Airborne Disease Transmission

\subsection{Background Disease Incidence}

645 Due to the predicted finite, but characteristically low, individual-person infection probability

646 rates in the general population, airborne diseases that present similarly to other common, non-

647 airborne diseases may be prone to being under diagnosed and under reported. While an

648 individual event may not affect many people, the cumulative impact of routine, small-scale

649 events could pose a significant health burden. More accurately defining the airborne disease

650 burden may be important since with appropriately targeted programs, there is a potential to

651 reduce the currently existing US population airborne disease burden.

652 As an illustration, Q Fever is a disease with a well-established airborne transmission pathway

653 and disease control measures exist [59]. Q Fever is often considered a rare disease; however, it

654 is known that Q Fever cases are significantly underreported even though it is a US nationally

655 notifiable disease with mandatory reporting in most states [60], [61]. US nationally

656 representative data from 2003 to 2004 suggest that the overall adult population prevalence of

657 acute, recent, and chronic Coxiella infections is 6 million people, 3\% of the general US

658 population [62]. Further analysis of this data indicates the prevalence of Acute Q Fever (Coxiella

659 burnetti) infections may be approximately 2 million people, see Supplemental Material H: U.S.

660 Coxiella burnetti Infection and Disease Estimates. ${ }^{19}$ For comparison, during this time period

661 there were 70 Q Fever cases in the national reporting system [64], [65] and in 2017 there were

662153 acute and 40 chronic Q Fever cases reported in the US [66]. Disease underreporting rates

663 are similar for other major airborne disease mentioned here. For example, among US

664 hospitalized persons with pneumonia, Legionnaire's Disease is ten times more common than

665 currently being diagnosed [67].

666 Accurately estimating background disease rates is also an important step in investigating

667 epidemic outbreaks as these are needed to produce accurate absolute outbreak incidence

668 estimates and relative risks. We note that true population-based background incidence and

669 prevalence rates are unavailable for most diseases. ${ }^{20}$ This literature gap is a practical matter as

670 analysts often arbitrarily choose the lowest observed incidence rates at a location adjacent to

671 the main body of outbreak cases as a background reference rate. However, as seen above,

672 infections at these distances might be due to long-distance airborne transmission as this work

673 suggests that once an infectious particle is airborne, there is a non-zero probability of infections

674 downwind. Misclassification of background disease rates could result in inaccurate (a)

${ }^{19}$ Direct contact and vectors (ticks) are also known to transmit Coxiella infections and so these estimates may not be solely due to airborne transmission [61], [63].

${ }^{20}$ A notable exception is focused vaccine safety studies which perform population-based assessments of background prevalence of rare diseases as a baseline to compare against rare adverse vaccine events, e.g., [68]. 
medRxiv preprint doi: https://doi.org/10.1101/2020.04.23.20076273; this version posted April 28, 2020. The copyright holder for this preprint (which was not certified by peer review) is the author/funder, who has granted medRxiv a license to display the preprint in perpetuity. It is made available under a CC-BY-NC-ND 4.0 International license .

M Dillon and C Dillon Particle Model for Airborne Disease Transmission

675

676

677

678

679

680

681

682

683

684

estimation of the true spatial extent of an outbreak and (b) dose-response modeling [69]. There is also risk of undiagnosed cases and secondary disease spread.

\subsection{Key Infectious Agent/Disease Characteristics}

Only select infectious agents can transmit disease via inhalation of a single particle, particularly over longer ( $>5 \mathrm{~m}$ ) distances. Based on Equation 2, the key infectious agent/disease characteristics that determine the likelihood of airborne transmission are (a) the number of infectious particles emitted, (b) the degree of infectivity of individual particles, and (c) the loss of particle infectivity while airborne. Table 3 summarizes these characteristics.

Table 3. Summary of Factors Relevant to Single Particle Airborne Disease Transmission

The number of infectious airborne particles emitted must be comparable to, or larger than, the number required to expose a downwind individual.

A single particle must carry sufficient infectious material to cause disease when inhaled.

Airborne transport must occur rapidly enough so that enough infectious particles are present downwind. This can happen in one of two ways.

(1) Airborne infectivity losses could be negligible.

(2) Infectious particles are transported fast enough so that airborne losses are limited.

\subsubsection{Number of Infectious Particles Emitted: [Total Particles Released]}

With respect to Case $2\left(R_{0}>1\right)$ human diseases, human-origin particles can comprise a significant fraction of indoor airborne particles, e.g., [70], [71], and ill individuals are known to emit infectious particles through coughing, sneezing, breathing, and/or shedding of infected skin or mucosal cells [71]-[74]. While it is challenging to develop reliable estimates of the number of infectious particles emitted by an ill individual, working estimates of total human 692 respirable (1 to $5 \mu \mathrm{m} \mathrm{AD)}$ particle emissions are available from published studies. For context, 693 up to $10^{6}$ airborne particles can be emitted per sneeze (although there is some debate on the 694 fraction of these particles that are respirable) [75], [76]; $10^{3}$ to $10^{5}$ respirable diameter particles 695 are emitted both in a cough and for short (15 to 30 minute) periods of breathing and talking 696 [33], [73], [77]-[80]; and $10^{7}$ skin cells are shed per day (of which a fraction become airborne 697 respirable particles) [53], [81]. We note that sick individuals may emit more particles than 698 healthy individuals and some individuals can emit an order of magnitude or more particles than 
medRxiv preprint doi: https://doi.org/10.1101/2020.04.23.20076273; this version posted April 28, 2020. The copyright holder for this preprint (which was not certified by peer review) is the author/funder, who has granted medRxiv a license to display the preprint in perpetuity. It is made available under a CC-BY-NC-ND 4.0 International license .

M Dillon and C Dillon

Particle Model for Airborne Disease Transmission the average person, e.g., super-spreaders [77], [82]. For context, we estimate $10^{4}$ to $10^{6}$ environmentally stable infectious particles emitted indoors are required to infect one downwind person in an urban area $\left(0.01\right.$ people $\left.\mathrm{m}^{-2}\right){ }^{21}$

\subsubsection{Single Particle Infectivity: [Single Particle Infection Probability]}

704 Individual particles need to carry enough infectious material to cause disease. For some disease-causing infectious agents, this is a given as they possess a very low infectious inhalation dose. One example is Coxiella burnetii, which causes $Q$ Fever, where a single bacterium can potentially cause infection in humans [15], [83].22 For other infectious agents, multiple individual agents are required for infection. Theoretically, the required number of infectious agents may be transported on the surface of, or within, larger carrier particles. ${ }^{23}$ From physical considerations alone, approximately $1001 \mu \mathrm{m}$ AD infectious agents (a common bacteria size) could fit within a single $5 \mu \mathrm{m}$ AD particle. ${ }^{24}$ For smaller agents, such as viruses, the number of

${ }^{21}$ Figure 5a suggests that the outdoor release of $10^{3}$ to $10^{5}$ particles would infect a downwind outdoor individual. A factor of $10 x$ reduction is added to account for both (a) the fraction of particles released indoors that exit the building and enter the outdoor atmosphere and (b) protection that downwind buildings protect their occupancy, see Supplemental Material G: Infection Estimates.

${ }^{22}$ The dose required to infect $50 \%$ of the human subjects is 1.18 bacteria ( $95 \% \mathrm{Cl}: 0.76$ to 40.2 ).

${ }^{23}$ Bacteria have the capacity to bind to a wide variety of surfaces and particles and depending on the vehicle, multiple bacteria can become airborne, including on the surface of human skin cells, e.g., [84]. Furthermore, viruses and bacteria such as Tuberculosis, Coxiella burnetti, Legionella Pneumophilia, Chlamydia pneumoniae and others are intracellular pathogens, i.e., they infect host hosts by penetrating within cells where they reside and multiply [85]. Thus, there is the potential for multiple pathogens to be present in a single particle when the infected cells are exhaled (or exfoliated) as airborne particles [86]. We are unaware of a field experiment demonstrating multiple infectious agents present on a single airborne particle, no doubt due to the technical challenges involved [87]. However, this characteristic has been demonstrated in the laboratory, e.g., [88].

${ }^{24}$ (1) This $0^{\text {th }}$ order estimate is based on volume considerations and assumes a spherical geometry. (2) the number of agents actually present in a particle will also depend on other factors and can be much smaller. 
medRxiv preprint doi: https://doi.org/10.1101/2020.04.23.20076273; this version posted April 28, 2020. The copyright holder for this preprint (which was not certified by peer review) is the author/funder, who has granted medRxiv a license to display the preprint in perpetuity. It is made available under a CC-BY-NC-ND 4.0 International license .

M Dillon and

C Dillon

Particle Model for Airborne Disease Transmission

\subsubsection{Loss of Particle Infectivity While Airborne: Affects [Normalized TSIAC]}

Some infectious agents - including important human pathogens and economically important plant disease pathogens - are environmentally hardy and are known to readily transmit disease over long distances - causing significant disease outbreaks [57], [89]-[95]. However, other agents, including many human and veterinary pathogens, are more fragile and their potential for long-distance airborne disease transmission is more controversial. For some of these pathogens, the rate at which infectivity is lost in the atmosphere can be high and depends, in part, on the specific virus or microorganism and strain, microbial state (e.g., vegetative cell vs. spore), environmental conditions (e.g., temperature, humidity, insolation), and particle composition [96]-[98]. For context, reported airborne loss rates for a collection of pathogens

725 (Category A select agents) range from undetectable to up to about $5 \mathrm{~h}^{-1}$ when expressed as a first order (base e) loss rate [98]. Observed loss rates are not always first order, as it is common to observe an initial "die-off" followed by a slower loss rate for a relatively hardy subpopulation, and so an alternate metric is also informative. These same studies reported that time required for $90 \%$ of the original material to be lost is at least $15 \mathrm{~min}$ [98].

The mere existence of notable atmospheric infectivity loss rates may not, in and of itself, prevent agents from transmitting disease via the atmosphere. Indeed, many of the examples provided in the medium and long range subsections of the Supplemental Material A: Airborne

Disease Transmission Literature Review are known to have significant airborne loss rates.

734 However, our modeling results indicate that even when infectivity is lost rapidly, $10 \mathrm{~h}^{-1}$,

735 infection probabilities are minimally impacted several hundred meters downwind, see Figure

736 7b. Longer distance airborne transmission of infectious agents with notable atmospheric loss

737 rates is also facilitated by the following:

First, environmental conditions (e.g., insolation, temperature and humidity) are not fixed and so airborne disease transmission may simply be limited to when conditions are favorable for agent atmospheric survival. As one example, viruses or microorganisms that are sensitive to solar (UV) radiation would not be affected at night. ${ }^{25}$ Similarly, UV exposure varies significantly by latitude, season, time of day, cloud cover, air pollution, airborne dust, indoors vs. outdoors, etc. . Similar considerations hold true for other common environmental variables including humidity and temperature.

${ }^{25}$ Also, bacteria have the ability to repair injuries induced by environmental damage. With regard to UV radiation, [99] reviews of the effects of UV on viruses and makes the point that much of the existing published literature relates to the more potent UV (UV-C) radiation spectrum used in commercial UV germicidal irradiation devices. As UV-C does not reach the earth's surface; natural ground-level solar UV wavelengths fall in the less viricidal UV-A and B spectrum above $290 \mathrm{~nm}$. 
medRxiv preprint doi: https://doi.org/10.1101/2020.04.23.20076273; this version posted April 28, 2020. The copyright holder for this preprint

(which was not certified by peer review) is the author/funder, who has granted medRxiv a license to display the preprint in perpetuity.

It is made available under a CC-BY-NC-ND 4.0 International license .

M Dillon and

C Dillon

Particle Model for

Airborne Disease Transmission

Second, even if there is a significant airborne infectivity loss rate, disease transmission might occur if the outdoor atmospheric transport is rapid relative to the loss rate. For many common weather conditions, downwind transport of airborne particles may indeed be rapid - with kilometer scale transport occurring in 15 minutes or less. ${ }^{26}$ When airborne infectivity loss rates are significant, infection rates are predicted to be higher at higher wind speeds, see Figure 6. For context when airborne infectivity loss rates are negligible, infection rates are predicted to be higher during the night (stable atmospheric conditions) and at lower wind speeds, see Figure $\mathbf{5}$.

${ }^{26}$ As an illustrative example, moderate winds, $4.5 \mathrm{~m} \mathrm{~s}^{-1}$, would transport an outdoor airborne particle 1 $\mathrm{km}$ downwind in about $4 \mathrm{~min}$. This example is intended for illustrative purposes as it does not consider the effects of atmospheric turbulence (e.g., plume dispersion) nor the known increase of wind speed with height above the earth's surface. Furthermore, this calculation focuses on outdoor emissions and exposures. Particles emitted indoors will take time to move outdoors and, similarly, outdoor particles will take additional time to travel indoors to expose indoor people. 
medRxiv preprint doi: https://doi.org/10.1101/2020.04.23.20076273; this version posted April 28, 2020. The copyright holder for this preprint (which was not certified by peer review) is the author/funder, who has granted medRxiv a license to display the preprint in perpetuity. It is made available under a CC-BY-NC-ND 4.0 International license .

M Dillon and

C Dillon
Particle Model for Airborne Disease Transmission

\subsection{Potential Future Efforts}

754 This paper develops new theory for airborne disease transmission; models potential physical

755 exposures; provides a selective literature review of airborne disease transmission; and provides

756 an initial model comparison to published epidemiological data of the predicted relative

757 infection/disease prevalence as a function of downwind distance for a single source region.

758 However, the key variables and modeling parameters presented here are necessarily general

759 and/or limited to archetypical cases.

760

761

762

763

764

765

766

767

768

769

770

771

772

773

774

775

776

777

778

779

780

781

More detailed analyses could provide more accurate predictions for specific scenarios and coupled with laboratory, epidemiological, and/or field measurements - could also be used to validate the work presented in this paper. These detailed analyses could consider:

(a) specific agents, particle properties, environmental conditions, and population demographics; ${ }^{27}$

(b) mobile populations;

(c) particle distributions (including sizes greater than $5 \mu \mathrm{m} \mathrm{AD);}$

(d) improved exposure modeling particularly for (i) outdoor exposures $<50 \mathrm{~m}$ and $>20 \mathrm{~km}$ from the source and (ii) indoor exposures where which the indoor air is not well mixed, e.g., < few meters from the source; and

(e) other disease transmission pathways, such as droplets, fomites, and direct/indirect contact including the case in which outdoor airborne particles travel indoors, deposit on indoor surfaces, and pose an on-going contact or resuspension hazard.

We note that special, at-risk, populations, such as (a) children $<5$ years of age, (b) the elderly, or (c) immune compromised persons, may have higher infection disease risks relative to the general population, e.g., the examples of influenza risks or Aspergillus infections in immune compromised people.

After appropriate scientific peer review and validation, applications of this research may help enhance airborne disease outbreak management and chronically occurring airborne exposure management. Potential future research areas are briefly highlighted here, although we note that such work should be conducted with due consideration of (a) the potential impact on, or interaction with, other disease transmission pathways ${ }^{28}$ and (b) other factors, such as food,

${ }^{27}$ We note that the effects of known variations in the building stock, population demographic distributions, and daily population mobility patterns could be assessed prior to the outbreak event and used to in real time to provide higher fidelity quantitative results [30], [31].

${ }^{28}$ Many viruses and microorganisms are opportunistic and so may have multiple, simultaneous disease transmission pathways. 
medRxiv preprint doi: https://doi.org/10.1101/2020.04.23.20076273; this version posted April 28, 2020. The copyright holder for this preprint (which was not certified by peer review) is the author/funder, who has granted medRxiv a license to display the preprint in perpetuity. It is made available under a CC-BY-NC-ND 4.0 International license .

M Dillon and C Dillon

Particle Model for Airborne Disease Transmission

water, medical needs, resource limitations, communication capabilities, expected population compliance, and impending hazards (e.g. fire).

The theory developed here could inform future updates to remediation clearance and biosafety criteria, i.e., how clean is clean enough. As one example, the interim B. anthracis clearance strategy suggests a best-practice clearance goal of no detectable viable spores on any environmental sample [100]. This goal was selected, in part, because the dose (exposure) response (infectivity or disease) relationship for $\mathrm{B}$. anthracis is not sufficiently understood to adequately assess disease risk. The theory presented in this paper, coupled with estimates of how much surface contamination could become airborne, could bound the downwind risk - even in the absence of any data on a dose-response relationship.

Suspectable populations could be protected when high-risk environmental conditions are forecasted [101]-[103]. This response paradigm is in common use for other airborne hazards where evacuation ${ }^{29}$ and shelter (see next paragraph) are routinely used protective actions [31].

Sheltering has the potential to reduce airborne disease spread, both within a single building as well as further downwind. Sheltering actions may include changes to population locations (e.g., shelter in place) as well as changes to building stock and operations (e.g., weatherization programs to reduce indoor/outdoor air change rates; improved particulate filtration). The use of mass ("cleaner-air") shelters, such as those currently used to reduce population level outdoor wildfire smoke (air quality) exposures, should be carefully considered in infectious disease settings as some diseases can rapidly spread when many people are in close quarters.

${ }^{29}$ The airborne infection probability is predicted to be directly proportional to population density and so reducing the number of people at risk in high density regions, such as through zoning changes or preventative evacuation, could reduce the overall disease spread rate. 
medRxiv preprint doi: https://doi.org/10.1101/2020.04.23.20076273; this version posted April 28, 2020. The copyright holder for this preprint (which was not certified by peer review) is the author/funder, who has granted medRxiv a license to display the preprint in perpetuity. It is made available under a CC-BY-NC-ND 4.0 International license .

M Dillon and

C Dillon
Particle Model for Airborne Disease Transmission

\section{Acknowledgements}

807 The authors are grateful to their family for their support and enduring patience. The authors 808 also thank Ron Baskett and John Nasstrom of the Lawrence Livermore National Laboratory for 809 their considerable assistance in developing the Supplemental Material B: Key Atmospheric 810 Transport and Dispersion Modeling Concepts section. Furthermore, the authors acknowledge 811 the assistance of Brooke Buddemeier, Steve Homann, Brenda Pobanz, Ellen Raber, Antoun 812 Tarabay, and Ken Turteltaub of the Lawrence Livermore National Laboratory; Richard Sextro of 813 Lawrence Berkeley National Laboratory; David Brown of Argonne National Laboratory; Dev Jani 814 of the US Department of Homeland Security, Countering Weapons of Mass Destruction Office; 815 Frederick Miller of the National Institute of Health; William Rhodes of Mele Associates, Inc.; 816 Benjamin Arnold of the University of California, San Francisco; Joseph Chang of the RAND 817 Corporation; Michael Mastrangelo of the University of Texas Medical Branch; and Mark Nicas 818 of the University of California, Berkeley during the development of this manuscript. Financial 819 support was provided by the US Department of Homeland Security for related early efforts and 820 the Lawrence Livermore National Laboratory for facilitating the review of this material. Finally, 821 the authors would like to thank Freepik for the icons, designed by Freepik from Flaticon 822 (www.flaticon.com), used, in part, in the development of Figures 1 and D1.

823 This document was prepared as an account of work sponsored by an agency of the United 824 States government. Neither the United States government nor Lawrence Livermore National 825 Security, LLC, nor any of their employees makes any warranty, expressed or implied, or assumes 826 any legal liability or responsibility for the accuracy, completeness, or usefulness of any 827 information, apparatus, product, or process disclosed, or represents that its use would not 828 infringe privately owned rights. Reference herein to any specific commercial product, process, 829 or service by trade name, trademark, manufacturer, or otherwise does not necessarily 830 constitute or imply its endorsement, recommendation, or favoring by the United States 831 government or Lawrence Livermore National Security, LLC. The views and opinions of authors 832 expressed herein do not necessarily state or reflect those of the United States government or 833 Lawrence Livermore National Security, LLC, and shall not be used for advertising or product 834 endorsement purposes.

835 Lawrence Livermore National Laboratory is operated by Lawrence Livermore National Security, 836 LLC, for the U.S. Department of Energy, National Nuclear Security Administration under 837 Contract DE-AC52-07NA27344. 
medRxiv preprint doi: https://doi.org/10.1101/2020.04.23.20076273; this version posted April 28, 2020. The copyright holder for this preprint (which was not certified by peer review) is the author/funder, who has granted medRxiv a license to display the preprint in perpetuity. It is made available under a CC-BY-NC-ND 4.0 International license .

M Dillon and

C Dillon
Particle Model for Airborne Disease Transmission

\section{Attestations}

\section{Ethics statement}

842

843

No humans or animals were used this in work

\section{Data accessibility}

No primary data were used in this analysis. The referenced supplemental materials have been provided.

\section{Competing interests}

The authors have no competing interests for the material provided in this manuscript beyond (a) being and/or previously employed at our respective organizations and (b) receiving funding from the acknowledged sources.

\section{Author's contributions}

Michael Dillon (MBD) was responsible for the study concept and design, theory development, modeling, and data analysis.

Charles Dillon (CFD) was responsible for the epidemiologic content (including identification of previously reported outbreak data) and, jointly with MBD, developed the Supplemental Material A: Airborne Disease Transmission Literature Review Discussion and Supplemental Material H: U.S. Coxiella burnetti Infection and Disease Estimates sections.

Ron Baskett (RB) and MBD developed the Supplemental Material B: Key Atmospheric Transport and Dispersion Modeling Concepts (i.e., RB was a co-author on this section). John Nasstrom provided significant feedback and suggestions.

MBD and CFD both participated in literature searches, manuscript drafting, and revision through its many versions.

All authors give approval for release.

\section{Funding statement}

MBD was supported, in part, by the US Department of Homeland Security for early efforts.

876 CFD was self-supported. 
medRxiv preprint doi: https://doi.org/10.1101/2020.04.23.20076273; this version posted April 28, 2020. The copyright holder for this preprint (which was not certified by peer review) is the author/funder, who has granted medRxiv a license to display the preprint in perpetuity. It is made available under a CC-BY-NC-ND 4.0 International license .

M Dillon and

C Dillon
Particle Model for Airborne Disease Transmission

\section{References}

878 [1] R. L. Riley et al., "Aerial dissemination of pulmonary tuberculosis. A two-year study of contagion in a tuberculosis ward. 1959," Am. J. Epidemiol., vol. 142, no. 1, pp. 3-14, Jul. 1995.

881

882

883

884

885

886

887

888

889

890

891

892

893

894

895

896

897

898

899

900

901

902

903

904

905

906

907

908

909

910

[2] A. D. Langmuir, "Airborne Infection: How Important for Public Health?: I. A Historical Review," Am. J. Public Health Nations Health, vol. 54, no. 10, pp. 1666-1668, Oct. 1964, doi: 10.2105/AJPH.54.10.1666.

[3] W. F. Wells, Airborne Contagion and Air Hygiene: An Ecological Study of Droplet Infections. Cambridge, Massachusetts: Harvard University Press, 1955.

[4] C. Troeger et al., "Estimates of the global, regional, and national morbidity, mortality, and aetiologies of lower respiratory infections in 195 countries, 1990-2016: a systematic analysis for the Global Burden of Disease Study 2016," Lancet Infect. Dis., vol. 18, no. 11, pp. 1191-1210, Nov. 2018, doi: 10.1016/S1473-3099(18)30310-4.

[5] "The top 10 causes of death." https://www.who.int/news-room/fact-sheets/detail/thetop-10-causes-of-death (accessed Jan. 23, 2020).

[6] B. Killingley and J. Nguyen-Van-Tam, "Routes of influenza transmission," Influenza Other Respir. Viruses, vol. 7, pp. 42-51, Sep. 2013, doi: 10.1111/irv.12080.

[7] J. S. Kutter, M. I. Spronken, P. L. Fraaij, R. A. Fouchier, and S. Herfst, "Transmission routes of respiratory viruses among humans," Curr. Opin. Virol., vol. 28, pp. 142-151, Feb. 2018, doi: 10.1016/j.coviro.2018.01.001.

[8] J. P. G. Van Leuken, A. N. Swart, A. H. Havelaar, A. Van Pul, W. Van der Hoek, and D. Heederik, "Atmospheric dispersion modelling of bioaerosols that are pathogenic to humans and livestock - A review to inform risk assessment studies," Microb. Risk Anal., vol. 1, pp. 19-39, Jan. 2016, doi: 10.1016/j.mran.2015.07.002.

[9] R. E. Britter, "Atmospheric dispersion of dense gases," Annu. Rev. Fluid Mech., vol. 21, no. 1, pp. 317-344, 1989.

[10] US Environmental Protection Agency, Office of Air Quality Planning and Standards, "Quality Assurance Handbook for Air Pollution Measurement Systems Volume IV Meteorological Measurements, Version 2.0 (Final)," US Environmental Protection Agency, Research Triangle Park, NC, EPA-454-B-08-002, Mar. 2008.

[11] US National Weather Service, "Automated Surface Observing System (ASOS) User's Guide," US National Oceanic and Atmospheric Administration, US Department of Defense, US Federal Aviation Administration, and US Navy, Silver Spring, MD, Mar. 1998. [Online]. Available: https://www.weather.gov/media/asos/aum-toc.pdf. 
medRxiv preprint doi: https://doi.org/10.1101/2020.04.23.20076273; this version posted April 28, 2020. The copyright holder for this preprint (which was not certified by peer review) is the author/funder, who has granted medRxiv a license to display the preprint in perpetuity. It is made available under a CC-BY-NC-ND 4.0 International license .

M Dillon and

C Dillon

Particle Model for Airborne Disease Transmission

911

912

913

914

915

916

917

918

919

920

921

922

923

924

925

926

927

928

929

930

931

932

933

934

935

936

937

938

939

940

941

942

943

944

945

946

947

[12] US Department of Energy, "Environmental Radiological Effluent Monitoring and Environmental Surveillance," US Department of Energy, Washington DC, DOE Handbook, DOE-HDBK--2015 1216. [Online]. Available: https://www.id.energy.gov/ESER/DOC/DOEHDBK-1216-2015v2.pdf.

[13] World Meteorological Organization, Guide to meteorological instruments and methods of observation. Geneva, Switzerland: World Meteorological Organization, 2008.

[14] US Nuclear Regulatory Commission, "Regulatory Guide 1.23 - Meteorological Monitoring Programs for Nuclear Power Plants (Revision 1)," US Nuclear Regulatory Commission, Office of Nuclear Regulatory Research, Washington DC, Mar. 2007. [Online]. Available: https://www.nrc.gov/docs/ML0703/ML070350028.pdf.

[15] R. J. Brooke, M. E. Kretzschmar, N. T. Mutters, and P. F. Teunis, "Human dose response relation for airborne exposure to Coxiella burnetii," BMC Infect. Dis., vol. 13, no. 1, p. 488, 2013, doi: 10.1186/1471-2334-13-488.

[16] D. J. A. Toth et al., "Quantitative Models of the Dose-Response and Time Course of Inhalational Anthrax in Humans," PLoS Pathog., vol. 9, no. 8, p. e1003555, Aug. 2013, doi: 10.1371/journal.ppat.1003555.

[17] R. Hardy, K. Schilling, J. Fromm, X. Dai, and M. Cook, "Technical Background Document: Microbial Risk Assessment and Fate and Transport Modeling of Aerosolized Microorganisms at Wastewater Land Application Facilities in Idaho," Idaho Department of Environmental Quality, Feb. 2006. [Online]. Available: https://www.deq.idaho.gov/media/529643-microbial_risk_assessment.pdf.

[18] V. Nilsen and J. Wyller, "QMRA for Drinking Water: 1. Revisiting the Mathematical Structure of Single-Hit Dose-Response Models: QMRA: Structure of Single-Hit DoseResponse Models," Risk Anal., vol. 36, no. 1, pp. 145-162, Jan. 2016, doi: 10.1111/risa.12389.

[19] C. N. Haas, "Conditional Dose-Response Relationships for Microorganisms: Development and Application," Risk Anal., vol. 22, no. 3, pp. 455-463, Jun. 2002, doi: 10.1111/02724332.00035.

[20] P. F. M. Teunis et al., "Norwalk virus: How infectious is it?," J. Med. Virol., vol. 80, no. 8, pp. 1468-1476, Aug. 2008, doi: 10.1002/jmv.21237.

[21] N. Van Abel, M. E. Schoen, J. C. Kissel, and J. S. Meschke, "Comparison of Risk Predicted by Multiple Norovirus Dose-Response Models and Implications for Quantitative Microbial Risk Assessment: Comparison of Risk Predicted by Multiple Norovirus Dose-Response Models," Risk Anal., Jun. 2016, doi: 10.1111/risa.12616.

[22] N. E. Klepeis et al., "The National Human Activity Pattern Survey (NHAPS): a resource for assessing exposure to environmental pollutants," J. Expo. Anal. Environ. Epidemiol., vol. 11, no. 3, pp. 231-252, Jun. 2001, doi: 10.1038/sj.jea.7500165. 
medRxiv preprint doi: https://doi.org/10.1101/2020.04.23.20076273; this version posted April 28, 2020. The copyright holder for this preprint (which was not certified by peer review) is the author/funder, who has granted medRxiv a license to display the preprint in perpetuity. It is made available under a CC-BY-NC-ND 4.0 International license .

M Dillon and

C Dillon

Particle Model for Airborne Disease Transmission

948

949

950

951

952

953

954

955

956

957

958

959

960

961

962

963

964

965

966

967

968

969

970

971

972

973

974

975

976

977

978

979

980

981

982

983

984

[23] K. Teschke, Y. Chow, K. Bartlett, A. Ross, and C. van Netten, "Spatial and temporal distribution of airborne Bacillus thuringiensis var. kurstaki during an aerial spray program for gypsy moth eradication," Environ. Health Perspect., vol. 109, no. 1, pp. 47-54, 2001.

[24] B. G. Shelton, K. H. Kirkland, W. D. Flanders, and G. K. Morris, "Profiles of Airborne Fungi in Buildings and Outdoor Environments in the United States," Appl. Environ. Microbiol., vol. 68, no. 4, pp. 1743-1753, Apr. 2002, doi: 10.1128/AEM.68.4.1743-1753.2002.

[25] R.-P. Vonberg and P. Gastmeier, "Nosocomial aspergillosis in outbreak settings," J. Hosp. Infect., vol. 63, no. 3, pp. 246-254, Jul. 2006, doi: 10.1016/j.jhin.2006.02.014.

[26] J. R. Lentino, M. A. Rosenkranz, J. A. Michaels, V. P. Kurup, H. D. Rose, and M. W. Rytel, "Nosocomial aspergillosis: a retrospective review of airborne disease secondary to road construction and contaminated air conditioners," Am. J. Epidemiol., vol. 116, no. 3, pp. 430-437, Sep. 1982.

[27] J. P. Luby, P. M. Southern, C. E. Haley, K. L. Vahle, R. S. Munford, and R. W. Haley, "Recurrent exposure to Histoplasma capsulatum in modern air-conditioned buildings," Clin. Infect. Dis. Off. Publ. Infect. Dis. Soc. Am., vol. 41, no. 2, pp. 170-176, Jul. 2005, doi: 10.1086/430907.

[28] S. Chamany et al., "A large histoplasmosis outbreak among high school students in Indiana, 2001," Pediatr. Infect. Dis. J., vol. 23, no. 10, pp. 909-914, Oct. 2004.

[29] K. Benedict and R. K. Mody, "Epidemiology of Histoplasmosis Outbreaks, United States, 1938-2013," Emerg. Infect. Dis., vol. 22, no. 3, Mar. 2016, doi: 10.3201/eid2203.151117.

[30] M. B. Dillon, R. G. Sextro, and W. W. Delp, "Regional Shelter Analysis - Inhalation Exposure Application (Particles)," Lawrence Livermore National Laboratory, Livermore, CA, LLNL-TR786237, Aug. 2019.

[31] M. B. Dillon and C. F. Dillon, "Regional Shelter Analysis - Inhalation Exposure Methodology," Lawrence Livermore National Laboratory, Livermore, CA, LLNL-TR-786042, Aug. 2019.

[32] Z. T. Ai and A. K. Melikov, "Airborne spread of expiratory droplet nuclei between the occupants of indoor environments: A review," Indoor Air, vol. 28, no. 4, pp. 500-524, Jul. 2018, doi: 10.1111/ina.12465.

[33] M. Nicas, W. W. Nazaroff, and A. Hubbard, "Toward Understanding the Risk of Secondary Airborne Infection: Emission of Respirable Pathogens," J. Occup. Environ. Hyg., vol. 2, no. 3, pp. 143-154, Mar. 2005, doi: 10.1080/15459620590918466.

[34] W. W. Nazaroff, "Indoor bioaerosol dynamics," Indoor Air, vol. 26, no. 1, pp. 61-78, Feb. 2016, doi: 10.1111/ina.12174.

[35] D. Rim and A. Novoselac, "Transient Simulation of Airflow and Pollutant Dispersion Under Mixing Flow and Buoyancy Driven Flow Regimes in Residential Buildings," ASHRAE Trans., vol. 114, Part 2, pp. 130-142, 2008. 
medRxiv preprint doi: https://doi.org/10.1101/2020.04.23.20076273; this version posted April 28, 2020. The copyright holder for this preprint (which was not certified by peer review) is the author/funder, who has granted medRxiv a license to display the preprint in perpetuity. It is made available under a CC-BY-NC-ND 4.0 International license .

M Dillon and

C Dillon

Particle Model for Airborne Disease Transmission

985

986

987

988

989

990

991

992

993

994

995

996

997

998

999

1000

1001

1002

1003

1004

1005

1006

1007

1008

1009

1010

1011

1012

1013

1014

1015

1016

1017

1018

1019

1020

[36] W. W. Nazaroff, "Indoor particle dynamics," Indoor Air, vol. 14, no. s7, pp. 175-183, Aug. 2004, doi: 10.1111/j.1600-0668.2004.00286.x.

[37] A. Gilsdorf, C. Kroh, S. Grimm, E. Jensen, C. Wagner-Wiening, and K. Alpers, "Large Q fever outbreak due to sheep farming near residential areas, Germany, 2005," Epidemiol. Infect., vol. 136, no. 08, Aug. 2008, doi: 10.1017/S0950268807009533.

[38] A. Petroff and L. Zhang, "Development and validation of a size-resolved particle dry deposition scheme for application in aerosol transport models," Geosci. Model Dev., vol. 3, no. 2, pp. 753-769, Dec. 2010, doi: 10.5194/gmd-3-753-2010.

[39] W. C. Hinds, Aerosol technology: properties, behavior, and measurement of airborne particles, 2. ed. New York: Wiley, 1999.

[40] B. Schimmer et al., "The use of a geographic information system to identify a dairy goat farm as the most likely source of an urban Q-fever outbreak," BMC Infect. Dis., vol. 10, no. 1, p. 69, Dec. 2010, doi: 10.1186/1471-2334-10-69.

[41] J. P. van Leuken et al., "Improved correlation of human Q fever incidence to modelled C. burnetii concentrations by means of an atmospheric dispersion model," Int. J. Health Geogr., vol. 14, no. 1, p. 14, Dec. 2015, doi: 10.1186/s12942-015-0003-y.

[42] J. I. Hawker et al., "A large outbreak of $Q$ fever in the West Midlands: windborne spread into a metropolitan area?," Commun. Dis. Public Health PHLS, vol. 1, no. 3, pp. 180-187, Sep. 1998.

[43] K. Nygard et al., "An Outbreak of Legionnaires Disease Caused by Long-Distance Spread from an Industrial Air Scrubber in Sarpsborg, Norway," Clin. Infect. Dis., vol. 46, no. 1, pp. 61-69, Jan. 2008, doi: 10.1086/524016.

[44] T. M. Nhu Nguyen et al., "A Community-Wide Outbreak of Legionnaires Disease Linked to Industrial Cooling Towers-How Far Can Contaminated Aerosols Spread?," J. Infect. Dis., vol. 193, no. 1, pp. 102-111, Jan. 2006, doi: 10.1086/498575.

[45] E. Schneider, "A Coccidioidomycosis Outbreak Following the Northridge, Calif, Earthquake," JAMA J. Am. Med. Assoc., vol. 277, no. 11, p. 904, Mar. 1997, doi: 10.1001/jama.1997.03540350054033.

[46] R. W. Jibson, "A Public Health Issue Related to Collateral Seismic Hazards: The Valley Fever Outbreak Triggered by the 1994 Northridge, California Earthquake," Surv. Geophys., vol. 23, pp. 511-528, 2002.

[47] G. J. Boender et al., "Risk Maps for the Spread of Highly Pathogenic Avian Influenza in Poultry," PLoS Comput. Biol., vol. 3, no. 4, p. e71, 2007, doi: 10.1371/journal.pcbi.0030071.

[48] P. J. Bonney et al., "Spatial transmission of H5N2 highly pathogenic avian influenza between Minnesota poultry premises during the 2015 outbreak," PLOS ONE, vol. 13, no. 9, p. e0204262, Sep. 2018, doi: 10.1371/journal.pone.0204262. 
medRxiv preprint doi: https://doi.org/10.1101/2020.04.23.20076273; this version posted April 28, 2020. The copyright holder for this preprint (which was not certified by peer review) is the author/funder, who has granted medRxiv a license to display the preprint in perpetuity. It is made available under a CC-BY-NC-ND 4.0 International license .

M Dillon and

C Dillon

Particle Model for Airborne Disease Transmission

1021

1022

1023

1024

1025

1026

1027

1028

1029

1030

1031

1032

1033

1034

1035

1036

1037

1038

1039

1040

1041

1042

1043

1044

1045

1046

1047

1048

1049

1050

1051

1052

1053

1054

1055

1056

1057

[49] I. Dorigatti, P. Mulatti, R. Rosà, A. Pugliese, and L. Busani, "Modelling the spatial spread of H7N1 avian influenza virus among poultry farms in Italy," Epidemics, vol. 2, no. 1, pp. 2935, Mar. 2010, doi: 10.1016/j.epidem.2010.01.002.

[50] Y. Hayama, T. Yamamoto, S. Kobayashi, N. Muroga, and T. Tsutsui, "Mathematical model of the 2010 foot-and-mouth disease epidemic in Japan and evaluation of control measures," Prev. Vet. Med., vol. 112, no. 3-4, pp. 183-193, Nov. 2013, doi: 10.1016/j.prevetmed.2013.08.010.

[51] I. Chis Ster and N. M. Ferguson, "Transmission Parameters of the 2001 Foot and Mouth Epidemic in Great Britain," PLOS ONE, vol. 2, no. 6, p. e502, Jun. 2007, doi: 10.1371/journal.pone.0000502.

[52] J. A. Backer, T. J. Hagenaars, H. J. W. van Roermund, and M. C. M. de Jong, "Modelling the effectiveness and risks of vaccination strategies to control classical swine fever epidemics," J. R. Soc. Interface, vol. 6, no. 39, pp. 849-861, Oct. 2009, doi: 10.1098/rsif.2008.0408.

[53] M. B. Dillon, "Skin as a potential source of infectious foot and mouth disease aerosols," Proc. R. Soc. B Biol. Sci., vol. 278, no. 1713, pp. 1761-1769, Jun. 2011, doi: 10.1098/rspb.2010.2430.

[54] J. K. M. Brown, "Aerial Dispersal of Pathogens on the Global and Continental Scales and Its Impact on Plant Disease," Science, vol. 297, no. 5581, pp. 537-541, Jul. 2002, doi: 10.1126/science.1072678.

[55] D. J. Smith et al., "Intercontinental Dispersal of Bacteria and Archaea by Transpacific Winds," Appl. Environ. Microbiol., vol. 79, no. 4, pp. 1134-1139, Feb. 2013, doi: 10.1128/AEM.03029-12.

[56] D. J. Smith et al., "Free Tropospheric Transport of Microorganisms from Asia to North America," Microb. Ecol., vol. 64, no. 4, pp. 973-985, Nov. 2012, doi: 10.1007/s00248-0120088-9.

[57] M. Meyer et al., "Quantifying airborne dispersal routes of pathogens over continents to safeguard global wheat supply," Nat. Plants, vol. 3, no. 10, pp. 780-786, Oct. 2017, doi: 10.1038/s41477-017-0017-5.

[58] A. I. Donaldson and S. Alexandersen, "Predicting the spread of foot and mouth disease by airborne virus," Rev. Sci. Tech. Int. Off. Epizoot., vol. 21, no. 3, pp. 569-575, Dec. 2002.

[59] N. J. Clark and R. J. Soares Magalhães, "Airborne geographical dispersal of $Q$ fever from livestock holdings to human communities: a systematic review and critical appraisal of evidence," BMC Infect. Dis., vol. 18, no. 1, p. 218, Dec. 2018, doi: 10.1186/s12879-0183135-4.

[60] "Q Fever | Summary | NNDSS." https://wwwn.cdc.gov/nndss/conditions/q-fever/ (accessed Feb. 11, 2020). 
medRxiv preprint doi: https://doi.org/10.1101/2020.04.23.20076273; this version posted April 28, 2020. The copyright holder for this preprint (which was not certified by peer review) is the author/funder, who has granted medRxiv a license to display the preprint in perpetuity. It is made available under a CC-BY-NC-ND 4.0 International license .

M Dillon and

C Dillon

Particle Model for Airborne Disease Transmission

1058

1059

1060

1061

1062

1063

1064

1065

1066

1067

1068

1069

1070

1071

1072

1073

1074

1075

1076

1077

1078

1079

1080

1081

1082

1083

1084

1085

1086

1087

1088

1089

1090

1091

1092

1093

[61] A. Anderson et al., "Diagnosis and management of Q fever--United States, 2013: recommendations from CDC and the Q Fever Working Group [see also Errata in MMWR Recomm Rep 2013 62(35):730]," MMWR Recomm. Rep. Morb. Mortal. Wkly. Rep. Recomm. Rep. Cent. Dis. Control, vol. 62, no. RR-03, pp. 1-30, Mar. 2013.

[62] A. D. Anderson et al., "Seroprevalence of Q Fever in the United States, 2003-2004," Am. J. Trop. Med. Hyg., vol. 81, no. 4, pp. 691-694, Oct. 2009, doi: 10.4269/ajtmh.2009.09-0168.

[63] T. O. Berge and E. H. Lennette, "World distribution of $Q$ fever: human, animal and arthropod infection," Am. J. Hyg., vol. 57, no. 2, pp. 125-143, Mar. 1953.

[64] R. S. Hopkins et al., "Summary of Notifiable Diseases --- United States, 2003," Morb. Mortal. Wkly. Rep., vol. 52, no. 54, pp. 1-85, Apr. 2005.

[65] R. A. Jajosky et al., "Summary of Notifiable Diseases --- United States, 2004," Morb. Mortal. Wkly. Rep., vol. 53, no. 53, pp. 1-79, Jun. 2006.

[66] "Epidemiology and Statistics | Q Fever | CDC," Sep. 16, 2019. https://www.cdc.gov/qfever/stats/index.html (accessed Feb. 06, 2020).

[67] K. Cassell, P. Gacek, T. Rabatsky-Ehr, S. Petit, M. Cartter, and D. M. Weinberger, "Estimating the True Burden of Legionnaires' Disease," Am. J. Epidemiol., vol. 188, no. 9, pp. 1686-1694, Sep. 2019, doi: 10.1093/aje/kwz142.

[68] T. A. Rasmussen et al., "Use of population based background rates of disease to assess vaccine safety in childhood and mass immunisation in Denmark: nationwide population based cohort study," BMJ, vol. 345, no. sep17 1, pp. e5823-e5823, Sep. 2012, doi: 10.1136/bmj.e5823.

[69] V. H. Hackert et al., "Q Fever: Evidence of a Massive Yet Undetected Cross-Border Outbreak, With Ongoing Risk of Extra Mortality, in a Dutch-German Border Region," Transbound. Emerg. Dis., p. tbed.13505, Feb. 2020, doi: 10.1111/tbed.13505.

[70] J. Qian, D. Hospodsky, N. Yamamoto, W. W. Nazaroff, and J. Peccia, "Size-resolved emission rates of airborne bacteria and fungi in an occupied classroom: Size-resolved bioaerosol emission rates," Indoor Air, vol. 22, no. 4, pp. 339-351, Aug. 2012, doi: 10.1111/j.1600-0668.2012.00769.x.

[71] D. Hospodsky et al., "Human Occupancy as a Source of Indoor Airborne Bacteria," PLoS ONE, vol. 7, no. 4, p. e34867, Apr. 2012, doi: 10.1371/journal.pone.0034867.

[72] M. Ludlow et al., "Infection of lymphoid tissues in the macaque upper respiratory tract contributes to the emergence of transmissible measles virus," J. Gen. Virol., vol. 94, no. Pt_9, pp. 1933-1944, Sep. 2013, doi: 10.1099/vir.0.054650-0.

[73] J. Yan et al., "Infectious virus in exhaled breath of symptomatic seasonal influenza cases from a college community," Proc. Natl. Acad. Sci., vol. 115, no. 5, pp. 1081-1086, Jan. 2018, doi: 10.1073/pnas.1716561115. 
medRxiv preprint doi: https://doi.org/10.1101/2020.04.23.20076273; this version posted April 28, 2020. The copyright holder for this preprint (which was not certified by peer review) is the author/funder, who has granted medRxiv a license to display the preprint in perpetuity. It is made available under a CC-BY-NC-ND 4.0 International license .

M Dillon and

C Dillon

Particle Model for Airborne Disease Transmission

1094

1095

1096

1097

1098

1099

1100

1101

1102

1103

1104

1105

1106

1107

1108

1109

1110

1111

1112

1113

1114

1115

1116

1117

1118

1119

1120

1121

1122

1123

1124

1125

1126

1127

1128

1129

1130

1131

[74] W. G. Lindsley et al., "Viable influenza A virus in airborne particles expelled during coughs versus exhalations," Influenza Other Respir. Viruses, vol. 10, no. 5, pp. 404-413, Sep. 2016, doi: 10.1111/irv.12390.

[75] Z. Y. Han, W. G. Weng, and Q. Y. Huang, "Characterizations of particle size distribution of the droplets exhaled by sneeze," J. R. Soc. Interface, vol. 10, no. 88, p. 20130560, Nov. 2013, doi: 10.1098/rsif.2013.0560.

[76] J. P. Duguid, "The size and the duration of air-carriage of respiratory droplets and dropletnuclei," Epidemiol. Infect., vol. 44, no. 6, pp. 471-479, Sep. 1946, doi: 10.1017/S0022172400019288.

[77] J. Lee et al., "Quantity, Size Distribution, and Characteristics of Cough-generated Aerosol Produced by Patients with an Upper Respiratory Tract Infection," Aerosol Air Qual. Res., vol. 19, no. 4, pp. 840-853, 2019, doi: 10.4209/aaqr.2018.01.0031.

[78] W. Yang and L. C. Marr, "Dynamics of Airborne Influenza A Viruses Indoors and Dependence on Humidity," PLOS ONE, vol. 6, no. 6, p. e21481, Jun. 2011, doi: 10.1371/journal.pone.0021481.

[79] R. M. Jones, "Critical Review and Uncertainty Analysis of Factors Influencing Influenza Transmission: Factors Influencing Influenza Transmission," Risk Anal., vol. 31, no. 8, pp. 1226-1242, Aug. 2011, doi: 10.1111/j.1539-6924.2011.01598.x.

[80] S. Asadi, A. S. Wexler, C. D. Cappa, S. Barreda, N. M. Bouvier, and W. D. Ristenpart, "Aerosol emission and superemission during human speech increase with voice loudness," Sci. Rep., vol. 9, no. 1, p. 2348, Dec. 2019, doi: 10.1038/s41598-019-38808-z.

[81] W. C. Noble, "Dispersal of skin microorganisms*," Br. J. Dermatol., vol. 93, no. 4, pp. 477485, Oct. 1975, doi: 10.1111/j.1365-2133.1975.tb06527.x.

[82] D. A. Edwards et al., "Inhaling to mitigate exhaled bioaerosols," Proc. Natl. Acad. Sci., vol. 101, no. 50, pp. 17383-17388, Dec. 2004, doi: 10.1073/pnas.0408159101.

[83] R. J. Brooke, N. T. Mutters, O. Péter, M. E. E. Kretzschmar, and P. F. M. Teunis, "Exposure to low doses of Coxiella burnetii caused high illness attack rates: Insights from combining human challenge and outbreak data," Epidemics, vol. 11, pp. 1-6, Jun. 2015, doi: 10.1016/j.epidem.2014.12.004.

[84] T. E. P. Kimkes and M. Heinemann, "How bacteria recognise and respond to surface contact," FEMS Microbiol. Rev., vol. 44, no. 1, pp. 106-122, Jan. 2020, doi: 10.1093/femsre/fuz029.

[85] M. T. Silva, "Classical labeling of bacterial pathogens according to their lifestyle in the host: inconsistencies and alternatives," Front. Microbiol., vol. 3, p. 71, 2012, doi: 10.3389/fmicb.2012.00071.

[86] R. P. Clark and M. L. de Calcina-Goff, "Some aspects of the airborne transmission of infection," J. R. Soc. Interface, vol. 6, no. Suppl_6, pp. S767-S782, Dec. 2009, doi: 10.1098/rsif.2009.0236.focus. 
medRxiv preprint doi: https://doi.org/10.1101/2020.04.23.20076273; this version posted April 28, 2020. The copyright holder for this preprint (which was not certified by peer review) is the author/funder, who has granted medRxiv a license to display the preprint in perpetuity. It is made available under a CC-BY-NC-ND 4.0 International license .

M Dillon and

C Dillon

Particle Model for Airborne Disease Transmission

1132

1133

1134

1135

1136

1137

1138

1139

1140

1141

1142

1143

1144

1145

1146

1147

1148

1149

1150

1151

1152

1153

1154

1155

1156

1157

1158

1159

1160

1161

1162

1163

1164

1165

1166

1167

1168

[87] T. Šantl-Temkiv et al., "Bioaerosol field measurements: Challenges and perspectives in outdoor studies," Aerosol Sci. Technol., vol. 54, no. 5, pp. 520-546, May 2020, doi: 10.1080/02786826.2019.1676395.

[88] B. Lighthart, B. T. Shaffer, B. Marthi, and L. M. Ganio, "Artificial wind-gust liberation of microbial bioaerosols previously deposited on plants," Aerobiologia, vol. 9, no. 2-3, pp. 189-196, Dec. 1993, doi: 10.1007/BF02066261.

[89] S. A. Isard, S. H. Gage, P. Comtois, and J. M. Russo, "Principles of the Atmospheric Pathway for Invasive Species Applied to Soybean Rust," BioScience, vol. 55, no. 10, p. 851, 2005, doi: 10.1641/0006-3568(2005)055[0851:POTAPF]2.0.CO;2.

[90] S. A. Isard and S. H. Gage, Flow of life in the atmosphere: an airscape approach to understanding invasive organisms. East Lansing: Michigan State University Press, 2001.

[91] A. Rieux et al., "Long-Distance Wind-Dispersal of Spores in a Fungal Plant Pathogen: Estimation of Anisotropic Dispersal Kernels from an Extensive Field Experiment," PLoS ONE, vol. 9, no. 8, p. e103225, Aug. 2014, doi: 10.1371/journal.pone.0103225.

[92] S. A. Isard, J. M. Russo, and A. Ariatti, "The Integrated Aerobiology Modeling System applied to the spread of soybean rust into the Ohio River valley during September 2006," Aerobiologia, vol. 23, no. 4, pp. 271-282, Dec. 2007, doi: 10.1007/s10453-007-9073-z.

[93] P. Skelsey, G. J. T. Kessel, A. A. M. Holtslag, A. F. Moene, and W. van der Werf, "Regional spore dispersal as a factor in disease risk warnings for potato late blight: A proof of concept," Agric. For. Meteorol., vol. 149, no. 3-4, pp. 419-430, Mar. 2009, doi: 10.1016/j.agrformet.2008.09.005.

[94] M. Meyer, L. Burgin, M. C. Hort, D. P. Hodson, and C. A. Gilligan, "Large-Scale Atmospheric Dispersal Simulations Identify Likely Airborne Incursion Routes of Wheat Stem Rust Into Ethiopia," Phytopathology, p. PHYTO-01-17-003, Aug. 2017, doi: 10.1094/PHYTO-01-170035-FI.

[95] B. A. Walther and P. W. Ewald, "Pathogen survival in the external environment and the evolution of virulence," Biol. Rev., vol. 79, no. 4, pp. 849-869, Nov. 2004, doi: $10.1017 / \mathrm{S} 1464793104006475$.

[96] W. D. Griffiths and G. A. L. DeCosemo, "The assessment of bioaerosols: A critical review," J. Aerosol Sci., vol. 25, no. 8, pp. 1425-1458, Dec. 1994, doi: 10.1016/00218502(94)90218-6.

[97] J. W. Tang, "The effect of environmental parameters on the survival of airborne infectious agents," J. R. Soc. Interface, vol. 6, no. Suppl_6, pp. S737-S746, Dec. 2009, doi: 10.1098/rsif.2009.0227.focus.

[98] R. Sinclair, S. A. Boone, D. Greenberg, P. Keim, and C. P. Gerba, "Persistence of Category A Select Agents in the Environment," Appl. Environ. Microbiol., vol. 74, no. 3, pp. 555-563, Feb. 2008, doi: 10.1128/AEM.02167-07. 
medRxiv preprint doi: https://doi.org/10.1101/2020.04.23.20076273; this version posted April 28, 2020. The copyright holder for this preprint (which was not certified by peer review) is the author/funder, who has granted medRxiv a license to display the preprint in perpetuity. It is made available under a CC-BY-NC-ND 4.0 International license .

M Dillon and

C Dillon

Particle Model for Airborne Disease Transmission

1169

1170

1171

1172

1173

1174

1175

1176

1177

1178

1179

1180

1181

1182

1183

1184

1185

1186

1187

1188

1189

1190

1191

1192

1193

1194

1195

1196

1197

1198

1199

1200

1201

1202

1203

1204

[99] C. D. Lytle and J.-L. Sagripanti, "Predicted Inactivation of Viruses of Relevance to Biodefense by Solar Radiation," J. Virol., vol. 79, no. 22, pp. 14244-14252, Nov. 2005, doi: 10.1128/JVI.79.22.14244-14252.2005.

[100] US Environmental Protection Agency and Centers for Disease Control and Prevention, "Interim Clearance Strategy for Environments Contaminated with Bacillus anthracis," Washington DC, Jul. 2012. [Online]. Available: https://www.epa.gov/emergencyresponse/epacdc-interim-clearance-strategy-environments-contaminated-anthrax.

[101] D. Villanueva and K. Schepanski, "Investigation of atmospheric conditions fostering the spreading of legionnaires' disease in outbreaks related to cooling towers," Int. J. Biometeorol., vol. 63, no. 10, pp. 1347-1356, Oct. 2019, doi: 10.1007/s00484-019-017519.

[102] A. D. Hagerman et al., "Temporal and geographic distribution of weather conditions favorable to airborne spread of foot-and-mouth disease in the coterminous United States," Prev. Vet. Med., vol. 161, pp. 41-49, Dec. 2018, doi: 10.1016/j.prevetmed.2018.10.016.

[103] A. Russo, C. M. Gouveia, P. M. M. Soares, R. M. Cardoso, M. T. Mendes, and R. M. Trigo, "The unprecedented 2014 Legionnaires' disease outbreak in Portugal: atmospheric driving mechanisms," Int. J. Biometeorol., vol. 62, no. 7, pp. 1167-1179, Jul. 2018, doi: 10.1007/s00484-018-1520-8.

[104] S. M. Burrows, W. Elbert, M. G. Lawrence, and U. Pöschl, "Bacteria in the global atmosphere - Part 1: Review and synthesis of literature data for different ecosystems," Atmospheric Chem. Phys., vol. 9, no. 23, pp. 9263-9280, Dec. 2009, doi: 10.5194/acp-99263-2009.

[105] S. M. Burrows et al., "Bacteria in the global atmosphere - Part 2: Modeling of emissions and transport between different ecosystems," Atmospheric Chem. Phys., vol. 9, no. 23, pp. 9281-9297, Dec. 2009, doi: 10.5194/acp-9-9281-2009.

[106] V. R. Després et al., "Primary biological aerosol particles in the atmosphere: a review," Tellus B, vol. 64, no. 0, Feb. 2012, doi: 10.3402/tellusb.v64i0.15598.

[107] R. M. Bowers, A. P. Sullivan, E. K. Costello, J. L. Collett, R. Knight, and N. Fierer, "Sources of Bacteria in Outdoor Air across Cities in the Midwestern United States," Appl. Environ. Microbiol., vol. 77, no. 18, pp. 6350-6356, Sep. 2011, doi: 10.1128/AEM.05498-11.

[108] P. H. Gregory, Microbiology of the Atmosphere, 2nd ed. Aylesbury: Leonard Hill Books, 1973.

[109] A. M. Jones and R. M. Harrison, "The effects of meteorological factors on atmospheric bioaerosol concentrations-a review," Sci. Total Environ., vol. 326, no. 1-3, pp. 151-180, Jun. 2004, doi: 10.1016/j.scitotenv.2003.11.021. 
medRxiv preprint doi: https://doi.org/10.1101/2020.04.23.20076273; this version posted April 28, 2020. The copyright holder for this preprint (which was not certified by peer review) is the author/funder, who has granted medRxiv a license to display the preprint in perpetuity. It is made available under a CC-BY-NC-ND 4.0 International license .

M Dillon and

C Dillon

Particle Model for Airborne Disease Transmission

1205

1206

1207

1208

1209

1210

1211

1212

1213

1214

1215

1216

1217

1218

1219

1220

1221

1222

1223

1224

1225

1226

1227

1228

1229

1230

1231

1232

1233

1234

1235

1236

1237

1238

1239

1240

1241

1242

[110] Pan-American Aerobiology Association, M. Muilenberg, and H. Burge, Eds., Aerobiology: proceedings of the Pan-American Aerobiology Association. Boca Raton: Lewis Publishers, 1996.

[111] H. Salem, S. A. Katz, and Royal Society of Chemistry (Great Britain), Eds., Aerobiology: the toxicology of airborne pathogens and toxins. Cambridge: Royal Society of Chemistry, 2016.

[112] N. I. Stilianakis and Y. Drossinos, "Dynamics of infectious disease transmission by inhalable respiratory droplets," J. R. Soc. Interface, vol. 7, no. 50, pp. 1355-1366, Sep. 2010, doi: 10.1098/rsif.2010.0026.

[113] J. W. Tang, P. Wilson, N. Shetty, and C. J. Noakes, "Aerosol-Transmitted Infections-a New Consideration for Public Health and Infection Control Teams," Curr. Treat. Options Infect. Dis., vol. 7, no. 3, pp. 176-201, Sep. 2015, doi: 10.1007/s40506-015-0057-1.

[114] U.S. Centers for Disease Control and Prevention, "Meningococcal Disease," in The Pink Book: Course Textbook - Epidemiology and Prevention of Vaccine-Preventable Diseases, 13th ed., J. Hamborsky, A. Kroger, and S. Wolfe, Eds. Washington DC: Public Health Foundation, 2015.

[115] J. M. McLaughlin, F. L. Khan, E. A. Thoburn, R. E. Isturiz, and D. L. Swerdlow, "Rates of hospitalization for community-acquired pneumonia among US adults: A systematic review," Vaccine, vol. 38, no. 4, pp. 741-751, Jan. 2020, doi: 10.1016/j.vaccine.2019.10.101.

[116] Y. Li et al., "Role of ventilation in airborne transmission of infectious agents in the built environment - a multidisciplinary systematic review," Indoor Air, vol. 17, no. 1, pp. 2-18, Feb. 2007, doi: 10.1111/j.1600-0668.2006.00445.x.

[117] I. Eames, J. W. Tang, Y. Li, and P. Wilson, "Airborne transmission of disease in hospitals," J. R. Soc. Interface, vol. 6, no. Suppl_6, pp. S697-S702, Dec. 2009, doi: 10.1098/rsif.2009.0407.focus.

[118] W. Kowalski, Hospital Airborne Infection Control. Boca Raton: CRC Press, 2011.

[119] J. Alzona, B. L. Cohen, H. Rudolph, H. N. Jow, and J. O. Frohliger, "Indoor-outdoor relationships for airborne particulate matter of outdoor origin," Atmospheric Environ. 1967, vol. 13, no. 1, pp. 55-60, Jan. 1979, doi: 10.1016/0004-6981(79)90244-0.

[120] A. G. Arruda et al., "Aerosol Detection and Transmission of Porcine Reproductive and Respiratory Syndrome Virus (PRRSV): What Is the Evidence, and What Are the Knowledge Gaps?," Viruses, vol. 11, no. 8, p. 712, Aug. 2019, doi: 10.3390/v11080712.

[121] B. W. Mitchell and D. J. King, "Effect of negative air ionization on airborne transmission of Newcastle disease virus," Avian Dis., vol. 38, no. 4, pp. 725-732, Dec. 1994.

[122] H. Hakim et al., "Aerosol Disinfection Capacity of Slightly Acidic Hypochlorous Acid Water Towards Newcastle Disease Virus in the Air: An In Vivo Experiment," Avian Dis., vol. 59, no. 4, pp. 486-491, Dec. 2015, doi: 10.1637/11107-042115-Reg.1. 
medRxiv preprint doi: https://doi.org/10.1101/2020.04.23.20076273; this version posted April 28, 2020. The copyright holder for this preprint (which was not certified by peer review) is the author/funder, who has granted medRxiv a license to display the preprint in perpetuity. It is made available under a CC-BY-NC-ND 4.0 International license .

M Dillon and

C Dillon

Particle Model for Airborne Disease Transmission

1243

1244

1245

1246

1247

1248

1249

1250

1251

1252

1253

1254

1255

1256

1257

1258

1259

1260

1261

1262

1263

1264

1265

1266

1267

1268

1269

1270

1271

1272

1273

1274

1275

1276

1277

1278

1279

[123] S. Dee, S. Otake, and J. Deen, "Use of a production region model to assess the efficacy of various air filtration systems for preventing airborne transmission of porcine reproductive and respiratory syndrome virus and Mycoplasma hyopneumoniae: Results from a 2-year study," Virus Res., vol. 154, no. 1-2, pp. 177-184, Dec. 2010, doi: 10.1016/j.virusres.2010.07.022.

[124] D. D. Ferguson, T. C. Smith, K. J. Donham, and S. J. Hoff, "The Efficiency of Biofilters at Mitigating Airborne MRSA from a Swine Nursery," J. Agric. Saf. Health, vol. 21, no. 4, pp. 217-227, Oct. 2015, doi: 10.13031/jash.21.10716.

[125] P. J. Hitchcock et al., "Improving performance of HVAC systems to reduce exposure to aerosolized infectious agents in buildings; recommendations to reduce risks posed by biological attacks," Biosecurity Bioterrorism Biodefense Strategy Pract. Sci., vol. 4, no. 1, pp. 41-54, 2006, doi: 10.1089/bsp.2006.4.41.

[126] P. V. Nielsen, "Control of airborne infectious diseases in ventilated spaces," J. R. Soc. Interface, vol. 6, no. suppl_6, Dec. 2009, doi: 10.1098/rsif.2009.0228.focus.

[127] F. Memarzadeh, R. N. Olmsted, and J. M. Bartley, "Applications of ultraviolet germicidal irradiation disinfection in health care facilities: Effective adjunct, but not stand-alone technology," Am. J. Infect. Control, vol. 38, no. 5, pp. S13-S24, Jun. 2010, doi: 10.1016/j.ajic.2010.04.208.

[128] D. J. Alexander, "Newcastle disease and other avian paramyxoviruses," Rev. Sci. Tech. Int. Off. Epizoot., vol. 19, no. 2, pp. 443-462, Aug. 2000.

[129] D. J. Alexander, E. W. Aldous, and C. M. Fuller, "The long view: a selective review of 40 years of Newcastle disease research," Avian Pathol., vol. 41, no. 4, pp. 329-335, Aug. 2012, doi: 10.1080/03079457.2012.697991.

[130] D. E. Swayne, "Avian influenza vaccines and therapies for poultry," Comp. Immunol. Microbiol. Infect. Dis., vol. 32, no. 4, pp. 351-363, Jul. 2009, doi: 10.1016/j.cimid.2008.01.006.

[131] M. Hugh-Jones, W. H. Allan, F. A. Dark, and G. J. Harper, "The evidence for the airborne spread of Newcastle disease," J. Hyg. (Lond.), vol. 71, no. 02, pp. 325-339, Jun. 1973, doi: $10.1017 /$ S0022172400022786.

[132] J. Gloster, "Analysis of two outbreaks of Newcastle disease," Agric. Meteorol., vol. 28, no. 2, pp. 177-189, Feb. 1983, doi: 10.1016/0002-1571(83)90006-7.

[133] P. Vittoz and R. Engler, "Seed dispersal distances: a typology based on dispersal modes and plant traits," Bot. Helvetica, vol. 117, no. 2, pp. 109-124, Dec. 2007, doi: 10.1007/s00035-007-0797-8.

[134] S. J. Wright et al., "Understanding strategies for seed dispersal by wind under contrasting atmospheric conditions," Proc. Natl. Acad. Sci., vol. 105, no. 49, pp. 1908419089, Dec. 2008, doi: 10.1073/pnas.0802697105. 
medRxiv preprint doi: https://doi.org/10.1101/2020.04.23.20076273; this version posted April 28, 2020. The copyright holder for this preprint (which was not certified by peer review) is the author/funder, who has granted medRxiv a license to display the preprint in perpetuity. It is made available under a CC-BY-NC-ND 4.0 International license .

M Dillon and

C Dillon

Particle Model for Airborne Disease Transmission

1280

1281

1282

1283

1284

1285

1286

1287

1288

1289

1290

1291

1292

1293

1294

1295

1296

1297

1298

1299

1300

1301

1302

1303

1304

1305

1306

1307

1308

1309

1310

1311

1312

1313

1314

1315

[135] M. B. Soons, R. Nathan, and G. G. Katul, "Human Effects on Long-Distance Wind Dispersal and Colonization by Grassland Plants," Ecology, vol. 85, no. 11, pp. 3069-3079, Nov. 2004, doi: 10.1890/03-0398.

[136] P. M. Severns, K. E. Sackett, D. H. Farber, and C. C. Mundt, "Consequences of LongDistance Dispersal for Epidemic Spread: Patterns, Scaling, and Mitigation," Plant Dis., vol. 103, no. 2, pp. 177-191, Feb. 2019, doi: 10.1094/PDIS-03-18-0505-FE.

[137] C. M. Brown et al., "A community outbreak of Legionnaires' disease linked to hospital cooling towers: an epidemiological method to calculate dose of exposure," Int. J. Epidemiol., vol. 28, no. 2, pp. 353-359, Apr. 1999, doi: 10.1093/ije/28.2.353.

[138] J. Castilla et al., "A large Legionnaires' disease outbreak in Pamplona, Spain: early detection, rapid control and no case fatality," Epidemiol. Infect., vol. 136, no. 06, pp. 823832, Jun. 2008, doi: 10.1017/S0950268807009077.

[139] M. Sabria et al., "A community outbreak of Legionnaires' disease: evidence of a cooling tower as the source," Clin. Microbiol. Infect., vol. 12, no. 7, pp. 642-647, Jul. 2006, doi: 10.1111/j.1469-0691.2006.01447.x.

[140] C. R. Phares et al., "Legionnaires' disease among residents of a long-term care facility: The sentinel event in a community outbreak," Am. J. Infect. Control, vol. 35, no. 5, pp. 319-323, Jun. 2007, doi: 10.1016/j.ajic.2006.09.014.

[141] A. García-Fulgueiras et al., "Legionnaires' Disease Outbreak in Murcia, Spain," Emerg. Infect. Dis. , vol. 9, no. 8, pp. 915-921, Aug. 2003, doi: 10.3201/eid0908.030337.

[142] L. E. Garrison et al., "Vital Signs: Deficiencies in Environmental Control Identified in Outbreaks of Legionnaires' Disease - North America, 2000-2014," MMWR Morb. Mortal. Wkly. Rep., vol. 65, no. 22, pp. 576-584, Jun. 2016, doi: 10.15585/mmwr.mm6522e1.

[143] D. Weiss et al., "A Large Community Outbreak of Legionnaires' Disease Associated With a Cooling Tower in New York City, 2015," Public Health Rep., vol. 132, no. 2, pp. 241-250, Mar. 2017, doi: 10.1177/0033354916689620.

[144] R. Fitzhenry et al., "Legionnaires' Disease Outbreaks and Cooling Towers, New York City, New York, USA," Emerg. Infect. Dis., vol. 23, no. 11, Nov. 2017, doi:

10.3201/eid2311.161584.

[145] A. T. Chamberlain, J. D. Lehnert, and R. L. Berkelman, "The 2015 New York City Legionnaires' Disease Outbreak: A Case Study on a History-Making Outbreak," J. Public Health Manag. Pract., vol. 23, no. 4, pp. 410-416, 2017, doi: 10.1097/PHH.0000000000000558.

[146] M.-P. Brenier-Pinchart et al., "Influence of internal and outdoor factors on filamentous fungal flora in hematology wards," Am. J. Infect. Control, vol. 37, no. 8, pp. 631-637, Oct. 2009, doi: 10.1016/j.ajic.2009.03.013. 
medRxiv preprint doi: https://doi.org/10.1101/2020.04.23.20076273; this version posted April 28, 2020. The copyright holder for this preprint (which was not certified by peer review) is the author/funder, who has granted medRxiv a license to display the preprint in perpetuity. It is made available under a CC-BY-NC-ND 4.0 International license .

M Dillon and

C Dillon

Particle Model for Airborne Disease Transmission

1316

1317

1318

1319

1320

1321

1322

1323

1324

1325

1326

1327

1328

1329

1330

1331

1332

1333

1334

1335

1336

1337

1338

1339

1340

1341

1342

1343

1344

1345

1346

1347

1348

1349

1350

1351

1352

[147] C. C. Chang et al., "Consensus guidelines for implementation of quality processes to prevent invasive fungal disease and enhanced surveillance measures during hospital building works, 2014: Quality processes in prevention of IFD," Intern. Med. J., vol. 44, no. 12b, pp. 1389-1397, Dec. 2014, doi: 10.1111/imj.12601.

[148] J. E. Blair, Y.-H. H. Chang, Y. Ruiz, S. Duffy, B. E. Heinrich, and D. F. Lake, "Distance from Construction Site and Risk for Coccidioidomycosis, Arizona, USA," Emerg. Infect. Dis., vol. 20, no. 9, pp. 1464-1471, Sep. 2014, doi: 10.3201/eid2009.131588.

[149] R. S. Dungan, "Estimation of Infectious Risks in Residential Populations Exposed to Airborne Pathogens During Center Pivot Irrigation of Dairy Wastewaters," Environ. Sci. Technol., vol. 48, no. 9, pp. 5033-5042, May 2014, doi: 10.1021/es405693v.

[150] R. S. Dungan, "BOARD-INVITED REVIEW: Fate and transport of bioaerosols associated with livestock operations and manures," J. Anim. Sci., vol. 88, no. 11, pp. 3693-3706, Nov. 2010, doi: 10.2527/jas.2010-3094.

[151] N. Wery, "Bioaerosols from composting facilities - a review," Front. Cell. Infect. Microbiol., vol. 4, Apr. 2014, doi: 10.3389/fcimb.2014.00042.

[152] E. D. Berry et al., "Effect of Proximity to a Cattle Feedlot on Escherichia coli 0157:H7 Contamination of Leafy Greens and Evaluation of the Potential for Airborne Transmission," Appl. Environ. Microbiol., vol. 81, no. 3, pp. 1101-1110, Feb. 2015, doi: 10.1128/AEM.02998-14.

[153] P. Douglas et al., "Use of dispersion modelling for Environmental Impact Assessment of biological air pollution from composting: Progress, problems and prospects," Waste Manag., vol. 70, pp. 22-29, Dec. 2017, doi: 10.1016/j.wasman.2017.08.023.

[154] P. Douglas et al., "Predicting Aspergillus fumigatus exposure from composting facilities using a dispersion model: A conditional calibration and validation," Int. J. Hyg. Environ. Health, vol. 220, no. 1, pp. 17-28, Jan. 2017, doi: 10.1016/j.ijheh.2016.09.017.

[155] Y. Li, H. Zhang, X. Qiu, Y. Zhang, and H. Wang, “Dispersion and Risk Assessment of Bacterial Aerosols Emitted from Rotating-Brush Aerator during Summer in a Wastewater Treatment Plant of Xi'an, China," Aerosol Air Qual. Res., vol. 13, no. 6, pp. 1807-1814, 2013, doi: 10.4209/aaqr.2012.09.0245.

[156] M. L. Cain, B. G. Milligan, and A. E. Strand, “Long-distance seed dispersal in plant populations," Am. J. Bot., vol. 87, no. 9, pp. 1217-1227, Sep. 2000.

[157] R. Nathan, “Long-Distance Dispersal of Plants," Science, vol. 313, no. 5788, pp. 786-788, Aug. 2006, doi: 10.1126/science.1124975.

[158] R. Nathan et al., "Mechanistic models of seed dispersal by wind," Theor. Ecol., vol. 4, no. 2, pp. 113-132, May 2011, doi: 10.1007/s12080-011-0115-3.

[159] D. E. Aylor, "Spread of Plant Disease on a Continental Scale: Role of Aerial Dispersal of Pathogens," Ecology, vol. 84, no. 8, pp. 1989-1997, Aug. 2003, doi: 10.1890/01-0619. 
medRxiv preprint doi: https://doi.org/10.1101/2020.04.23.20076273; this version posted April 28, 2020. The copyright holder for this preprint (which was not certified by peer review) is the author/funder, who has granted medRxiv a license to display the preprint in perpetuity. It is made available under a CC-BY-NC-ND 4.0 International license .

M Dillon and

C Dillon

Particle Model for Airborne Disease Transmission

1353

1354

1355

1356

1357

1358

1359

1360

1361

1362

1363

1364

1365

1366

1367

1368

1369

1370

1371

1372

1373

1374

1375

1376

1377

1378

1379

1380

1381

1382

1383

1384

1385

1386

1387

1388

[160] J. Gloster et al., "Airborne spread of foot-and-mouth disease - Model intercomparison," Vet. J., vol. 183, no. 3, pp. 278-286, Mar. 2010, doi: 10.1016/j.tvjl.2008.11.011.

[161] J. Gloster, A. Freshwater, R. F. Sellers, and S. Alexandersen, "Re-assessing the likelihood of airborne spread of foot-and-mouth disease at the start of the 1967-1968 UK foot-andmouth disease epidemic," Epidemiol. Infect., vol. 133, no. 05, p. 767, Apr. 2005, doi: $10.1017 /$ S0950268805004073.

[162] J. Gloster, L. Burgin, A. Jones, and R. Sanson, "Atmospheric dispersion models and their use in the assessment of disease transmission," Rev. Sci. Tech. Int. Off. Epizoot., vol. 30, no. 2, pp. 457-465, Aug. 2011.

[163] H. P. Spijkerboer et al., "Ability of the Gaussian plume model to predict and describe spore dispersal over a potato crop," Ecol. Model., vol. 155, no. 1, pp. 1-18, Sep. 2002, doi: 10.1016/S0304-3800(01)00475-6.

[164] M. C. Fisher et al., "Emerging fungal threats to animal, plant and ecosystem health," Nature, vol. 484, no. 7393, pp. 186-194, Apr. 2012, doi: 10.1038/nature10947.

[165] D. E. Aylor, G. S. Taylor, and G. S. Raynor, "Long-range transport of tobacco blue mold spores," Agric. Meteorol., vol. 27, no. 3-4, pp. 217-232, Dec. 1982, doi: 10.1016/00021571(82)90007-3.

[166] M. Blanco-Meneses, I. Carbone, and J. B. Ristaino, "Population structure and migration of the Tobacco Blue Mold Pathogen, Peronospora tabacina, into North America and Europe," Mol. Ecol., vol. 27, no. 3, pp. 737-751, Feb. 2018, doi: 10.1111/mec.14453.

[167] V. R. Brown and S. N. Bevins, "A review of virulent Newcastle disease viruses in the United States and the role of wild birds in viral persistence and spread," Vet. Res., vol. 48, no. 1 , p. 68, Dec. 2017, doi: 10.1186/s13567-017-0475-9.

[168] J. Davis, M. G. Garner, and I. J. East, "Analysis of Local Spread of Equine Influenza in the Park Ridge Region of Queensland," Transbound. Emerg. Dis., vol. 56, no. 1-2, pp. 31-38, Mar. 2009, doi: 10.1111/j.1865-1682.2008.01060.x.

[169] A. Ssematimba, T. J. Hagenaars, and M. C. M. de Jong, "Modelling the Wind-Borne Spread of Highly Pathogenic Avian Influenza Virus between Farms," PLoS ONE, vol. 7, no. 2, p. e31114, Feb. 2012, doi: 10.1371/journal.pone.0031114.

[170] R. J. F. Ypma et al., "Genetic Data Provide Evidence for Wind-Mediated Transmission of Highly Pathogenic Avian Influenza," J. Infect. Dis., vol. 207, no. 5, pp. 730-735, Mar. 2013, doi: $10.1093 /$ infdis/jis757.

[171] J. Gloster, "Risk of airborne spread of foot-and-mouth disease from the continent to England," Vet. Rec., vol. 111, no. 13, pp. 290-295, Sep. 1982.

[172] J. Gloster, R. F. Sellers, and A. I. Donaldson, "Long distance transport of foot-and-mouth disease virus over the sea," Vet. Rec., vol. 110, no. 3, pp. 47-52, Jan. 1982. 
medRxiv preprint doi: https://doi.org/10.1101/2020.04.23.20076273; this version posted April 28, 2020. The copyright holder for this preprint (which was not certified by peer review) is the author/funder, who has granted medRxiv a license to display the preprint in perpetuity. It is made available under a CC-BY-NC-ND 4.0 International license .

M Dillon and

C Dillon

Particle Model for Airborne Disease Transmission

1389

1390

1391

1392

1393

1394

1395

1396

1397

1398

1399

1400

1401

1402

1403

1404

1405

1406

1407

1408

1409

1410

1411

1412

1413

1414

1415

1416

1417

1418

1419

1420

1421

1422

1423

1424

[173] J. Gloster, R. M. Blackall, R. F. Sellers, and A. I. Donaldson, "Forecasting the airborne spread of foot-and-mouth disease," Vet. Rec., vol. 108, no. 17, pp. 370-374, Apr. 1981.

[174] L. S. Christensen, "Analysis of the epidemiological dynamics during the 1982-1983 epidemic of foot-and-mouth disease in Denmark based on molecular high-resolution strain identification," J. Gen. Virol., vol. 86, no. 9, pp. 2577-2584, Sep. 2005, doi: 10.1099/vir.0.80878-0.

[175] T. Mikkelsen et al., "Investigation of airborne foot-and-mouth disease virus transmission during low-wind conditions in the early phase of the UK 2001 epidemic," Atmospheric Chem. Phys., vol. 3, no. 6, pp. 2101-2110, Nov. 2003, doi: 10.5194/acp-3-2101-2003.

[176] J. H. Sorensen, D. K. J. Mackay, C. O. Jensen, and A. I. Donaldson, "An integrated model to predict the atmospheric spread of foot-and-mouth disease virus," Epidemiol. Infect., vol. 124, no. 3, pp. 577-590, 2000.

[177] H. Tissot-Dupont, M.-A. Amadei, M. Nezri, and D. Raoult, "Wind in November, Q Fever in December," Emerg. Infect. Dis., vol. 10, no. 7, pp. 1264-1269, Jul. 2004, doi: 10.3201/eid1007.030724.

[178] H. Tissot-Dupont, S. Torres, M. Nezri, and D. Raoult, "Hyperendemic focus of Q fever related to sheep and wind," Am. J. Epidemiol., vol. 150, no. 1, pp. 67-74, Jul. 1999.

[179] G. Dupuis, J. Petite, O. Péter, and M. Vouilloz, "An Important Outbreak of Human Q Fever in a Swiss Alpine Valley," Int. J. Epidemiol., vol. 16, no. 2, pp. 282-287, 1987, doi: 10.1093/ije/16.2.282.

[180] V. H. Hackert et al., "Q Fever: Single-Point Source Outbreak With High Attack Rates and Massive Numbers of Undetected Infections Across an Entire Region," Clin. Infect. Dis., vol. 55, no. 12, pp. 1591-1599, Dec. 2012, doi: 10.1093/cid/cis734.

[181] P. M. Schneeberger, C. Wintenberger, W. van der Hoek, and J. P. Stahl, "Q fever in the Netherlands - 2007-2010: What we learned from the largest outbreak ever," Médecine Mal. Infect., vol. 44, no. 8, pp. 339-353, Aug. 2014, doi: 10.1016/j.medmal.2014.02.006.

[182] W. van der Hoek et al., "Q fever in the Netherlands: an update on the epidemiology and control measures," Euro Surveill. Bull. Eur. Sur Mal. Transm. Eur. Commun. Dis. Bull., vol. 15, no. 12, Mar. 2010.

[183] A. Parr, E. A. Whitney, and R. L. Berkelman, "Legionellosis on the Rise: A Review of Guidelines for Prevention in the United States," J. Public Health Manag. Pract., vol. 21, no. 5, pp. E17-E26, 2015, doi: 10.1097/PHH.0000000000000123.

[184] P. Ulleryd et al., "Legionnaires' disease from a cooling tower in a community outbreak in Lidköping, Sweden- epidemiological, environmental and microbiological investigation supported by meteorological modelling," BMC Infect. Dis., vol. 12, no. 1, p. 313, 2012, doi: 10.1186/1471-2334-12-313. 
medRxiv preprint doi: https://doi.org/10.1101/2020.04.23.20076273; this version posted April 28, 2020. The copyright holder for this preprint (which was not certified by peer review) is the author/funder, who has granted medRxiv a license to display the preprint in perpetuity. It is made available under a CC-BY-NC-ND 4.0 International license .

M Dillon and

C Dillon

Particle Model for Airborne Disease Transmission

1425

1426

1427

1428

1429

1430

1431

1432

1433

1434

1435

1436

1437

1438

1439

1440

1441

1442

1443

1444

1445

1446

1447

1448

1449

1450

1451

1452

1453

1454

1455

1456

1457

1458

1459

1460

[185] E. Wedege et al., "Seroepidemiological Study after a Long-Distance Industrial Outbreak of Legionnaires' Disease," Clin. Vaccine Immunol., vol. 16, no. 4, pp. 528-534, Apr. 2009, doi: 10.1128/CVI.00458-08.

[186] C. Nguyen et al., "Recent Advances in Our Understanding of the Environmental, Epidemiological, Immunological, and Clinical Dimensions of Coccidioidomycosis," Clin. Microbiol. Rev., vol. 26, no. 3, pp. 505-525, Jul. 2013, doi: 10.1128/CMR.00005-13.

[187] D. J. D’Alessio, R. H. Heeren, S. L. Hendricks, P. Ogilvie, and M. L. Furcolow, “A starling roost as the source of urban epidemic histoplasmosis in an area of low incidence," Am. Rev. Respir. Dis., vol. 92, no. 5, pp. 725-731, Nov. 1965, doi: 10.1164/arrd.1965.92.5.725.

[188] F. E. Tosh, I. L. Doto, D. J. D'Alessio, A. A. Medeiros, S. L. Hendricks, and T. D. Chin, "The second of two epidemics of histoplasmosis resulting from work on the same starling roost," Am. Rev. Respir. Dis., vol. 94, no. 3, pp. 406-413, Sep. 1966, doi: 10.1164/arrd.1966.94.3.406.

[189] T. F. Sellers, "An Epidemic of Erythema Multiforme and Erythema Nodosum Caused by Histoplasmosis," Ann. Intern. Med., vol. 62, no. 6, pp. 1244-1262, Jun. 1965, doi: 10.7326/0003-4819-62-6-1244.

[190] W. F. Schlech et al., "Recurrent urban histoplasmosis, Indianapolis, Indiana, 1980-1981," Am. J. Epidemiol., vol. 118, no. 3, pp. 301-312, Sep. 1983.

[191] D. J. Drutz, "Urban Coccidioidomycosis and Histoplasmosis: Sacramento and Indianapolis," N. Engl. J. Med., vol. 301, no. 7, pp. 381-382, Aug. 1979, doi: 10.1056/NEJM197908163010711.

[192] L. J. Wheat, "A Large Urban Outbreak of Histoplasmosis: Clinical Features," Ann. Intern. Med., vol. 94, no. 3, pp. 331-337, Mar. 1981, doi: 10.7326/0003-4819-94-3-331.

[193] A. Lauer et al., "Combining Forces - The Use of Landsat TM Satellite Imagery, Soil Parameter Information, and Multiplex PCR to Detect Coccidioides immitis Growth Sites in Kern County, California," PLoS ONE, vol. 9, no. 11, p. e111921, Nov. 2014, doi: 10.1371/journal.pone.0111921.

[194] W. J. Harris and P. D. Roffers, "Assessing Erosion Potential and Coccidioides immitis Probability Using Existing Geologic and Soils Data," in Digital Mapping Techniques '10Workshop Proceedings" U.S. Geological Survey Open-File Report 2012-1171, Sacramento, CA, 2010, [Online]. Available: http://pubs.usgs.gov/of/2012/1171/.

[195] G. Thompson, J. Brown, K. Benedict, and B. Park, "Coccidioidomycosis: epidemiology," Clin. Epidemiol., p. 185, Jun. 2013, doi: 10.2147/CLEP.S34434.

[196] G. Sondermeyer, L. Lee, D. Gilliss, F. Tabnak, and D. Vugia, “Coccidioidomycosisassociated Hospitalizations, California, USA, 2000-2011," Emerg. Infect. Dis., vol. 19, no. 10, Oct. 2013, doi: 10.3201/eid1910.130427. 
medRxiv preprint doi: https://doi.org/10.1101/2020.04.23.20076273; this version posted April 28, 2020. The copyright holder for this preprint (which was not certified by peer review) is the author/funder, who has granted medRxiv a license to display the preprint in perpetuity. It is made available under a CC-BY-NC-ND 4.0 International license .

M Dillon and

C Dillon

Particle Model for Airborne Disease Transmission

1461

1462

1463

1464

1465

1466

1467

1468

1469

1470

1471

1472

1473

1474

1475

1476

1477

1478

1479

1480

1481

1482

1483

1484

1485

1486

1487

1488

1489

1490

1491

1492

1493

1494

1495

1496

1497

1498

[197] D. Q. Tong, J. X. L. Wang, T. E. Gill, H. Lei, and B. Wang, "Intensified dust storm activity and Valley fever infection in the southwestern United States: Dust and Valley Fever Intensification," Geophys. Res. Lett., vol. 44, no. 9, pp. 4304-4312, May 2017, doi: 10.1002/2017GL073524.

[198] K. Benedict and B. J. Park, "Invasive Fungal Infections after Natural Disasters," Emerg. Infect. Dis., vol. 20, no. 3, pp. 349-355, Mar. 2014, doi: 10.3201/eid2003.131230.

[199] R. W. Jibson, E. L. Harp, E. Schneider, R. A. Hajjeh, and R. A. Spiegel, "An outbreak of coccidioidomycosis (valley fever) caused by landslides triggered by the 1994 Northridge, California, earthquake," Geol. Soc. Rev. Eng. Geol., vol. 12, pp. 53-61, 1998.

[200] S. E. Thompson and G. G. Katul, "Implications of nonrandom seed abscission and global stilling for migration of wind-dispersed plant species," Glob. Change Biol., vol. 19, no. 6, pp. 1720-1735, Jun. 2013, doi: 10.1111/gcb.12173.

[201] Y. Mazar, E. Cytryn, Y. Erel, and Y. Rudich, "Effect of Dust Storms on the Atmospheric Microbiome in the Eastern Mediterranean," Environ. Sci. Technol., vol. 50, no. 8, pp. 41944202, Apr. 2016, doi: 10.1021/acs.est.5b06348.

[202] H. Behzad, K. Mineta, and T. Gojobori, "Global Ramifications of Dust and Sandstorm Microbiota," Genome Biol. Evol., vol. 10, no. 8, pp. 1970-1987, Aug. 2018, doi: 10.1093/gbe/evy134.

[203] T. Weil et al., "Legal immigrants: invasion of alien microbial communities during winter occurring desert dust storms," Microbiome, vol. 5, no. 1, p. 32, Dec. 2017, doi: 10.1186/s40168-017-0249-7.

[204] H. Peter, P. Hörtnagl, I. Reche, and R. Sommaruga, "Bacterial diversity and composition during rain events with and without Saharan dust influence reaching a high mountain lake in the Alps," Environ. Microbiol. Rep., vol. 6, no. 6, pp. 618-624, Dec. 2014, doi: 10.1111/1758-2229.12175.

[205] C. A. Kellogg et al., "Characterization of Aerosolized Bacteria and Fungi From Desert Dust Events in Mali, West Africa," Aerobiologia, vol. 20, no. 2, pp. 99-110, Jun. 2004, doi: 10.1023/B:AERO.0000032947.88335.bb.

[206] D. W. Griffin, "Atmospheric Movement of Microorganisms in Clouds of Desert Dust and Implications for Human Health," Clin. Microbiol. Rev., vol. 20, no. 3, pp. 459-477, Jul. 2007, doi: 10.1128/CMR.00039-06.

[207] P. N. Polymenakou, "Atmosphere: A Source of Pathogenic or Beneficial Microbes?," Atmosphere, vol. 3, no. 4, pp. 87-102, Jan. 2012, doi: 10.3390/atmos3010087.

[208] D. Pappagianis and H. Einstein, "Tempest from Tehachapi takes toll or Coccidioides conveyed aloft and afar," West. J. Med., vol. 129, no. 6, pp. 527-530, Dec. 1978.

[209] J. E. Hermansen, U. Torp, and L. P. Prahm, "Studies of Transport of Live Spores of Cereal Mildew and Rust Fungi across the North Sea," Grana, vol. 17, no. 1, pp. 41-46, Apr. 1978, doi: 10.1080/00173137809428851. 
medRxiv preprint doi: https://doi.org/10.1101/2020.04.23.20076273; this version posted April 28, 2020. The copyright holder for this preprint (which was not certified by peer review) is the author/funder, who has granted medRxiv a license to display the preprint in perpetuity. It is made available under a CC-BY-NC-ND 4.0 International license .

M Dillon and

C Dillon

Particle Model for Airborne Disease Transmission

1499

1500

1501

1502

1503

1504

1505

1506

1507

1508

1509

1510

1511

1512

1513

1514

1515

1516

1517

1518

1519

1520

1521

1522

1523

1524

1525

1526

1527

1528

1529

1530

1531

1532

1533

[210] C. C. Mundt, L. D. Wallace, T. W. Allen, C. A. Hollier, R. C. Kemerait, and E. J. Sikora, "Initial epidemic area is strongly associated with the yearly extent of soybean rust spread in North America," Biol. Invasions, vol. 15, no. 7, pp. 1431-1438, Jul. 2013, doi: 10.1007/s10530-012-0381-z.

[211] N. M. Flynn et al., "An Unusual Outbreak of Windborne Coccidioidomycosis," N. Engl. J. Med., vol. 301, no. 7, pp. 358-361, Aug. 1979, doi: 10.1056/NEJM197908163010705.

[212] "desertdust.jpeg (JPEG Image, $890 \times 690$ pixels)." https://geochange.er.usgs.gov/sw/impacts/geology/dust/desertdust.jpeg (accessed Jan. 27, 2020).

[213] P. L. Williams, D. L. Sable, P. Mendez, and L. T. Smyth, "Symptomatic Coccidioidomycosis following a Severe Natural Dust Storm," Chest, vol. 76, no. 5, pp. 566-570, Nov. 1979, doi: 10.1378/chest.76.5.566.

[214] W. A. Sprigg et al., "Regional dust storm modeling for health services: The case of valley fever," Aeolian Res., vol. 14, pp. 53-73, Sep. 2014, doi: 10.1016/j.aeolia.2014.03.001.

[215] A. De Visscher, Air dispersion modeling: foundations and applications. Hoboken, New Jersey: John Wiley \& Sons, Inc, 2014.

[216] S. R. Hanna, G. A. Briggs, and R. P. Hosker, "Handbook of Atmospheric Diffusion," US Department of Energy, Springfield, VA, DOE/TIC-11223, 1982.

[217] Tracking and Predicting the Atmospheric Dispersion of Hazardous Material Releases: Implications for Homeland Security. Washington, D.C.: National Academies Press, 2003.

[218] D. Randerson, "Atmospheric science and power production," DOE/TIC-27601, 6503687, Jul. 1984. doi: 10.2172/6503687.

[219] S. P. Arya, Air pollution meteorology and dispersion. New York: Oxford University Press, 1999.

[220] D. B. Turner, "Workbook of Atmospheric Dispersion Estimates," US Environmental Protection Agency, Office of Air Programs, Research Triangle Park, NC, AP-26, 1970.

[221] M. Z. Jacobson, Fundamentals of atmospheric modeling, 2nd ed. Cambridge, UK ; New York: Cambridge University Press, 2005.

[222] R. B. Stull, An Introduction to Boundary Layer Meteorology. Dordrecht: Springer Netherlands, 1988.

[223] D. H. Slade (Ed.), "Meteorology and Atomic Energy," Air Resources Laboratories for the US Atomic Energy Commission, Jul. 1968.

[224] S. K. Shah and E. Bou-Zeid, "Direct numerical simulations of turbulent Ekman layers with increasing static stability: modifications to the bulk structure and second-order statistics," J. Fluid Mech., vol. 760, pp. 494-539, Dec. 2014, doi: 10.1017/jfm.2014.597. 
medRxiv preprint doi: https://doi.org/10.1101/2020.04.23.20076273; this version posted April 28, 2020. The copyright holder for this preprint (which was not certified by peer review) is the author/funder, who has granted medRxiv a license to display the preprint in perpetuity. It is made available under a CC-BY-NC-ND 4.0 International license .

M Dillon and

C Dillon

Particle Model for Airborne Disease Transmission

1534

1535

1536

1537

1538

1539

1540

1541

1542

1543

1544

1545

1546

1547

1548

1549

1550

1551

1552

1553

1554

1555

1556

1557

1558

1559

1560

1561

1562

1563

1564

1565

1566

1567

1568

1569

1570

[225] S. M. I. Gohari and S. Sarkar, "Stratified Ekman layers evolving under a finite-time stabilizing buoyancy flux," J. Fluid Mech., vol. 840, pp. 266-290, Apr. 2018, doi: 10.1017/jfm.2018.58.

[226] J. C. Chang and S. R. Hanna, "Air quality model performance evaluation," Meteorol. Atmospheric Phys., vol. 87, no. 1-3, Sep. 2004, doi: 10.1007/s00703-003-0070-7.

[227] P. Zannetti, Ed., Air quality modeling: theories, methodologies, computational techniques, and available databases and software, vol. IV-Advances and Updates. United States of America: EnviroComp ; Air \& Waste Management Association, 2010.

[228] G. Sugiyama et al., "Atmospheric Dispersion Modeling: Challenges of the Fukushima Daiichi Response," Health Phys., vol. 102, no. 5, pp. 493-508, May 2012, doi: 10.1097/HP.0b013e31824c7bc9.

[229] J. S. Nasstrom, G. Sugiyama, R. L. Baskett, S. C. Larsen, and M. M. Bradley, "The National Atmospheric Release Advisory Center modelling and decision-support system for radiological and nuclear emergency preparedness and response," Int. J. Emerg. Manag., vol. 4, no. 3, p. 524, 2007, doi: 10.1504/IJEM.2007.014301.

[230] J. C. Weil, "Evaluation of the NARAC Modeling System Final Report to the Lawrence Livermore National Laboratory," Lawrence Livermore National Laboratory, Livermore, CA, UCRL-AR-217329, Nov. 2005.

[231] K. T. Foster, G. Sugiyama, J. S. Nasstrom, J. M. L. Jr., S. T. Chan, and B. M. Bowen, "The use of an operational model evaluation system for model intercomparison," Int. J. Environ. Pollut., vol. 14, no. 1/2/3/4/5/6, p. 77, 2000, doi: 10.1504/IJEP.2000.000528.

[232] S. Warner, J. F. Heagy, N. Platt, and M. B. Dillon, "Transport and Dispersion Model Predictions of Elevated Source Tracer Experiments in the Copenhagen Area: Comparisons of Hazard Prediction and Assessment Capability (HPAC) and National Atmospheric Release Advisory Center (NARAC) Emergency Response Model Predictions," Institute of Defense Analysis, Alexandra, VA, Technical Report D-3276, Jul. 2006.

[233] J. S. Nasstrom and J. C. Pace, "Evaluation of the effect of meteorological data resolution on Lagrangian particle dispersion simulations using the ETEX experiment," Atmos. Environ., vol. 32, no. 24, pp. 4187-4194, Dec. 1998, doi: 10.1016/S1352-2310(98)00180-0.

[234] S. G. Perry et al., "AERMOD: A Dispersion Model for Industrial Source Applications. Part II: Model Performance against 17 Field Study Databases," J. Appl. Meteorol., vol. 44, no. 5, pp. 694-708, May 2005, doi: 10.1175/JAM2228.1.

[235] US Environmental Protection Agency, "Exposure Factors Handbook 2011 Edition (Final)," US Environmental Protection Agency, Washington DC, EPA/600/R-09/052F.

[236] E. C. Riley, G. Murphy, and R. L. Riley, “Airborne spread of measles in a suburban elementary school," Am. J. Epidemiol., vol. 107, no. 5, pp. 421-432, May 1978, doi: 10.1093/oxfordjournals.aje.a112560. 
medRxiv preprint doi: https://doi.org/10.1101/2020.04.23.20076273; this version posted April 28, 2020. The copyright holder for this preprint (which was not certified by peer review) is the author/funder, who has granted medRxiv a license to display the preprint in perpetuity. It is made available under a CC-BY-NC-ND 4.0 International license .

M Dillon and

C Dillon

Particle Model for Airborne Disease Transmission

1571

1572

1573

1574

1575

1576

1577

1578

1579

1580

1581

1582

1583

1584

1585

1586

1587

1588

1589

1590

1591

1592

1593

1594

1595

1596

1597

1598

1599

1600

1601

1602

1603

1604

1605

1606

[237] G. N. Sze To and C. Y. H. Chao, "Review and comparison between the Wells-Riley and dose-response approaches to risk assessment of infectious respiratory diseases," Indoor Air, vol. 20, no. 1, pp. 2-16, Feb. 2010, doi: 10.1111/j.1600-0668.2009.00621.x.

[238] C. B. Keil, "A Tiered Approach to Deterministic Models for Indoor Air Exposures," Appl. Occup. Environ. Hyg., vol. 15, no. 1, pp. 145-151, Jan. 2000, doi: 10.1080/104732200301962.

[239] T. L. Thatcher, M. M. Lunden, K. L. Revzan, R. G. Sextro, and N. J. Brown, “A Concentration Rebound Method for Measuring Particle Penetration and Deposition in the Indoor Environment," Aerosol Sci. Technol., vol. 37, no. 11, pp. 847-864, Nov. 2003, doi: 10.1080/02786820300940.

[240] F. H. Shair and K. L. Heitner, "Theoretical model for relating indoor pollutant concentrations to those outside," Environ. Sci. Technol., vol. 8, no. 5, pp. 444-451, May 1974, doi: 10.1021/es60090a006.

[241] S. R. Hayes, "Use of an Indoor Air Quality Model (IAQM) to Estimate Indoor Ozone Levels," J. Air Waste Manag. Assoc., vol. 41, no. 2, pp. 161-170, Feb. 1991, doi: 10.1080/10473289.1991.10466833.

[242] J. M. Leone, J. S. Nasstrom, D. M. Maddix, D. J. Larson, G. Sugiyama, and D. L. Ermak, "Lagrangian Operational Dispersion Integrator (LODI) User's Guide v1.0," Lawrence Livermore National Laboratory, Livermore, CA, UCRL-AM-212798, 2001.

[243] G. Sugiyama and S. T. Chan, "A new meteorological data assimilation model for realtime emergency response," presented at the Tenth Joint Conference on the Applications of Air Pollution Meteorology, Phoenix, AZ, Jan. 1998, pp. 285-289.

[244] "Residential Energy Consumption Survey (RECS) - Data - U.S. Energy Information Administration (EIA)." https://www.eia.gov/consumption/residential/data/2015/ (accessed Jan. 19, 2020).

[245] M. Georgiev et al., " $Q$ fever in humans and farm animals in four European countries, 1982 to 2010," Euro Surveill. Bull. Eur. Sur Mal. Transm. Eur. Commun. Dis. Bull., vol. 18, no. 8, Feb. 2013.

[246] National Association of State Public Health Veterinarians and National Assembly of State Animal Health Officials, "Prevention and Control of Coxiella burnetii Infection among Humans and Animals: Guidance for a Coordinated Public Health and Animal Health Response," 2013. Accessed: Mar. 01, 2020. [Online]. Available: http://nasphv.org/Documents/Q_Fever_2013.pdf.

[247] T. J. O'Neill, J. M. Sargeant, and Z. Poljak, "The Effectiveness of Coxiella burnetii Vaccines in Occupationally Exposed Populations: A Systematic Review and Meta-Analysis," Zoonoses Public Health, vol. 61, no. 2, pp. 81-96, Mar. 2014, doi: 10.1111/zph.12054. 
medRxiv preprint doi: https://doi.org/10.1101/2020.04.23.20076273; this version posted April 28, 2020. The copyright holder for this preprint (which was not certified by peer review) is the author/funder, who has granted medRxiv a license to display the preprint in perpetuity. It is made available under a CC-BY-NC-ND 4.0 International license .

M Dillon and

C Dillon

Particle Model for Airborne Disease Transmission

1607

1608

1609

1610

1611

1612

1613

1614

1615

1616

1617

1618

1619

1620

1621

1622

1623

1624

1625

1626

1627

1628

1629

1630

1631

1632

1633

1634

1635

1636

1637

1638

1639

1640

1641

1642

1643

[248] P. M. Reeves, S. R. Paul, A. E. Sluder, T. A. Brauns, and M. C. Poznansky, "Q-vaxcelerate: A distributed development approach for a new Coxiella burnetii vaccine," Hum. Vaccines Immunother., vol. 13, no. 12, pp. 2977-2981, Dec. 2017, doi:

10.1080/21645515.2017.1371377.

[249] C. Eldin et al., "From Q Fever to Coxiella burnetii Infection: a Paradigm Change," Clin. Microbiol. Rev., vol. 30, no. 1, pp. 115-190, Jan. 2017, doi: 10.1128/CMR.00045-16.

[250] J. H. McQuiston and J. E. Childs, "Q fever in humans and animals in the United States," Vector Borne Zoonotic Dis. Larchmt. N, vol. 2, no. 3, pp. 179-191, 2002, doi: $10.1089 / 15303660260613747$.

[251] G. J. Kersh et al., "Presence of Coxiella burnetii DNA in the Environment of the United States, 2006 to 2008," Appl. Environ. Microbiol., vol. 76, no. 13, pp. 4469-4475, Jul. 2010, doi: 10.1128/AEM.00042-10.

[252] S. R. Porter, G. Czaplicki, J. Mainil, R. Guattéo, and C. Saegerman, "Q Fever: Current State of Knowledge and Perspectives of Research of a Neglected Zoonosis," Int. J. Microbiol., vol. 2011, pp. 1-22, 2011, doi: 10.1155/2011/248418.

[253] N. R. Parker, J. H. Barralet, and A. M. Bell, "Q fever," The Lancet, vol. 367, no. 9511, pp. 679-688, Feb. 2006, doi: 10.1016/S0140-6736(06)68266-4.

[254] S. Bacci, S. Villumsen, P. Valentiner-Branth, B. Smith, K. A. Krogfelt, and K. Mølbak, "Epidemiology and clinical features of human infection with Coxiella burnetii in Denmark during 2006-07," Zoonoses Public Health, vol. 59, no. 1, pp. 61-68, Feb. 2012, doi: 10.1111/j.1863-2378.2011.01419.x.

[255] H. K. Miller et al., "Trends in Q fever serologic testing by immunofluorescence from four large reference laboratories in the United States, 2012-2016," Sci. Rep., vol. 8, no. 1, p. 16670, Dec. 2018, doi: 10.1038/s41598-018-34702-2.

[256] H. W. Kaufman, Z. Chen, J. Radcliff, H. J. Batterman, and J. Leake, "Q fever: an underreported reportable communicable disease," Epidemiol. Infect., vol. 146, no. 10, pp. 12401244, Jul. 2018, doi: 10.1017/S0950268818001395.

[257] "NHANES 2003-2004: Coxiella Burnetii (Q Fever) Antibodies - Serum (Surplus) Data Documentation, Codebook, and Frequencies." https://wwwn.cdc.gov/Nchs/Nhanes/20032004/SSQFEV_C.htm (accessed Feb. 06, 2020).

[258] M. G. Walsh, "Assessing Q fever in a representative sample from the United States population: identification of a potential occupational hazard," Epidemiol. Infect., vol. 140, no. 1, pp. 42-46, Jan. 2012, doi: 10.1017/S0950268811000227.

[259] F. S. Dahlgren, D. L. Haberling, and J. H. McQuiston, “Q Fever is Underestimated in the United States: A Comparison of Fatal Q Fever Cases from Two National Reporting Systems," Am. J. Trop. Med. Hyg., vol. 92, no. 2, pp. 244-246, Feb. 2015, doi: 10.4269/ajtmh.14-0502. 
medRxiv preprint doi: https://doi.org/10.1101/2020.04.23.20076273; this version posted April 28, 2020. The copyright holder for this preprint (which was not certified by peer review) is the author/funder, who has granted medRxiv a license to display the preprint in perpetuity. It is made available under a CC-BY-NC-ND 4.0 International license .

M Dillon and

Particle Model for

C Dillon Airborne Disease Transmission

1644 [260] B. Schimmer et al., "Low seroprevalence of Q fever in The Netherlands prior to a series 1645 of large outbreaks," Epidemiol. Infect., vol. 140, no. 1, pp. 27-35, Jan. 2012, doi:

1647 10.1017/S0950268811000136.

1649

[261] H. F. Gidding et al., "Q fever seroprevalence in Australia suggests one in twenty people have been exposed," Epidemiol. Infect., vol. 148, p. e18, 2020, doi:

1650 $10.1017 /$ S0950268820000084. 
medRxiv preprint doi: https://doi.org/10.1101/2020.04.23.20076273; this version posted April 28, 2020. The copyright holder for this preprint (which was not certified by peer review) is the author/funder, who has granted medRxiv a license to display the preprint in perpetuity. It is made available under a CC-BY-NC-ND 4.0 International license .

M Dillon and

C Dillon
Particle Model for Airborne Disease Transmission

\section{Supplemental Material A: Airborne Disease Transmission Literature Review}

Air is not a sterile medium, as initially demonstrated in the early $19^{\text {th }}$ century experiments of Louis Pasteur. Bacteria and fungi are ubiquitous in the atmosphere and reach concentrations of about $10^{4}$ and $10^{3}$ cells $\mathrm{m}^{-3}$ in air, respectively [104]-[107]. These facts are well understood and elucidated in the field of Aerobiology which has documented the life cycles, including transport and dispersion, of naturally occurring airborne viruses, microorganisms, and bioaerosols [108][111]. However, there appears to be much confusion on the potential for airborne disease transmission, particularly at longer spatial scales due likely in part to the dispersed nature of this literature.

To provide the reader context for the main manuscript, this section briefly presents a set of well-documented airborne disease transmission examples on spatial scales ranging from a meter to thousands of kilometers. The specific cases discussed here are from the human disease as well as veterinary and agricultural biosafety ${ }^{30}$ literatures and have multiple studies showing airborne disease transmission. This synopsis is not intended to be comprehensive and we do not cite all relevant literature. We note that [8] is a useful literature review of atmospheric dispersion modeling for infectious diseases, with a focus on human and veterinary studies.

\section{Near Range $(<5 \mathrm{~m})$}

Near distance airborne disease spread $(\leq 5 \mathrm{~m})$ is common and occurs when infected individuals generate large quantities of infectious droplet (and droplet nuclei) particles when coughing or sneezing [33], [112]. Tuberculosis and the Measles virus (Rubeola) have long been known to transmit over this distance [1], [2]. Bordatella pertussis (Whooping Cough), Varicella Zoster virus (Chickenpox), Mumps virus, Rubella virus (German Measles) and Neisseria meningitides (bacterial meningitis) are additional examples [113], [114]. This near range airborne disease spread is known to contribute to the overall disease burden as lower respiratory infections and Tuberculosis are the $4^{\text {th }}$ and $10^{\text {th }}$ leading causes of death world-wide [5]. Finally, two percent of US adults (6.5 million) are hospitalized each year for treatment of community acquired pneumonias caused in part by the near-range airborne transmission of common bacteria and viruses including Influenza [115]. ${ }^{31}$

\footnotetext{
${ }^{30}$ airborne microbial threats to animal livestock or resulting from agricultural activities

${ }^{31}$ The airborne disease transmission pathway can contribute to overall disease transmission, even when other - droplet (> $5 \mu \mathrm{m}$ AD particles) and contact - pathways are important, e.g., [6], [7].
} 
medRxiv preprint doi: https://doi.org/10.1101/2020.04.23.20076273; this version posted April 28, 2020. The copyright holder for this preprint (which was not certified by peer review) is the author/funder, who has granted medRxiv a license to display the preprint in perpetuity. It is made available under a CC-BY-NC-ND 4.0 International license .

M Dillon and

C Dillon
Particle Model for Airborne Disease Transmission

\section{Short Range (5 $\mathrm{m}$ to $50 \mathrm{~m}$ )}

1683 Airborne disease spread is also known to occur over short distances ( $5 \mathrm{~m}$ to $50 \mathrm{~m}$ ) [34]. The spread of human pathogens within buildings has been particularly well documented in hospital environments [97], [116]-[118]. Furthermore, outdoor airborne particles are known to infiltrate indoors and cause disease in building occupants. ${ }^{32}$ Building air filtration systems and other measures are in active use to reduce the incidence of airborne animal diseases, e.g., Newcastle Disease virus, and porcine reproductive and respiratory syndrome (PRRS virus) [120]-[123]. Research also indicates that air filtration is beneficial to control MRSA in veterinary settings [124]. Furthermore, high-risk patient areas in hospitals are designed with physical and ventilation barriers to minimize infections in immune compromised patients. Hospital design features include, but are not limited to, permanently sealed hospital room windows and HEPA air filtration [116], [125], [126]. Ultraviolet germicidal irradiation is also routinely used to reduce airborne disease risk in hospital and other facilities, especially for Tuberculosis control [127].

The Newcastle Disease (ND) virus, an avian paramyxovirus, is one well-known example of an airborne disease that can transmit over short distances. ND virus is a commercially important pathogen in poultry production and virulent strains can be devastating, with flock mortality approaching $100 \%$ [128], [129]. ND virus has multiple routes of transmission, including airborne. ND vaccines have been a mainstay of ND control, but a number of pandemics have occurred and the disease remains endemic in many countries [129]. With regards to the plausibility of airborne transmission, we note some ND live virus vaccines are delivered via fine aerosolized powders [130]. Furthermore, experimental field studies have documented shortrange $(60 \mathrm{~m})$ airborne dispersion based on positive viral cultures of air samples [131], [132]. Recent experimental work has reconfirmed an airborne transmission route for ND virus [129]. Furthermore, outfitting buildings with negative air ionization and dilute viricidal chlorine aerosols may be useful in attenuating airborne disease transmission [121], [122].

In plant biology and biosafety studies, short-range $(<50 \mathrm{~m})$ airborne particle and pathogen transmissions are thought to be the most frequent scenarios. For example, initial median windborne (anemochorous) plant seed dispersals are typically short $(<10 \mathrm{~m})$ but the $95 \%$ th percentile for airborne seed dispersion occurs over longer distances and varies significantly by

1713 Tritici) and the wind-dispersed banana plant fungus Mycosphaerella fijiensis) [91], [136], single-

\footnotetext{
32 The physics of outdoor-origin particles penetrating buildings and exposing indoor individuals has been studied, e.g., [30] and is demonstrated by (a) indoor measurements of outdoor-origin $\mathrm{PM}_{2.5}$ particles [34], [119] and (b) airborne Bacillus thuringiensis bacteria infiltration into buildings [23].
} 
medRxiv preprint doi: https://doi.org/10.1101/2020.04.23.20076273; this version posted April 28, 2020. The copyright holder for this preprint (which was not certified by peer review) is the author/funder, who has granted medRxiv a license to display the preprint in perpetuity. It is made available under a CC-BY-NC-ND 4.0 International license .

M Dillon and C Dillon Particle Model for Airborne Disease Transmission field experimental studies are used to model initial local plot/field-level airborne pathogen dispersal and clearly demonstrate short-range airborne infection transmissions. These studies

1716 have been also used to develop source (emission) estimates for larger scale long-distance 1717 disease spread and propagated epidemics.

\section{Medium Range (50 $\mathrm{m}$ to $500 \mathrm{~m}$ )}

1720 Medium range airborne dispersions of infectious pathogens are well-documented in the plant 1721 biosafety, veterinary and human disease Epidemiology literature. These papers include both 1722 observational and experimental field studies coupled with physics-based airborne transport and 1723 dispersion modeling. Human data for downwind infections are primarily from epidemiology 1724 studies of unexpected disease outbreaks, supported by toxicology, clinical studies and 1725 environmental studies using background disease rate data.

1726 Epidemiologic disease outbreak studies provide human data for medium range ( $\leq 500 \mathrm{~m}$ ) 1727 airborne transmission of disease. Well-documented examples include ongoing community-level 1728 outbreaks of Legionnaire's Disease (Legionella pneumophilia) from building cooling towers 1729 [137]-[145]; Q Fever (Coxiella burnetii) transmission from livestock farms to their surrounding 1730 communities [37]; as well as Histoplasmosis (Histoplasma capsulatum) and Aspergillosis 1731 fumigatus and flavus dispersions from construction work or sites where contaminated soil is 1732 disturbed [25]-[29], [146].

1733 On this spatial scale, best-practices and regulatory standards aim to reduce the risk of airborne 1734 transport of infectious particles. Guidelines exist to control occupational and environmental construction-associated dust during building renovations. In endemic regions these guidelines are codified into law to reduce infections [147], [148]. Furthermore, there is a long standing, yet

1737 still evolving, literature that supports existing regulatory standards aimed at protecting workers 1738 and nearby communities from airborne pathogen dispersal from environmental sites such as composting facilities, sewage processing and waste-water aerosols, agricultural gray water aerosols, livestock feed yards and land applications of manure [17], [149]-[155]. As one example, a protective ring of up to $250 \mathrm{~m}$ is commonly specified under the assumption that existing air monitors detect little to no airborne material beyond that point [152], [153]. 
medRxiv preprint doi: https://doi.org/10.1101/2020.04.23.20076273; this version posted April 28, 2020. The copyright holder for this preprint (which was not certified by peer review) is the author/funder, who has granted medRxiv a license to display the preprint in perpetuity. It is made available under a CC-BY-NC-ND 4.0 International license .

M Dillon and

C Dillon
Particle Model for Airborne Disease Transmission

\section{Long Range (500 m to $500 \mathrm{~km})$}

1746 Long range airborne infectious pathogen transmission is also well-documented in plant biology, the plant and veterinary biosafety literature, as well as in human disease outbreak

1748 epidemiology studies. Long-distance atmospheric transmission mechanisms, termed LDD in this literature, have been shown to play a crucial ecological role in plant species invasion, migration and survival as well as plant pathogen dispersal [54], [57], [156]-[159]. This field is well advanced in its understanding of the connection between airborne pathogen transport and 1752 dispersion and disease epidemics [58], [160]-[163].

1753 Biosafety experimental field studies also clearly demonstrate kilometer-range dispersion of 1754 plant pathogens. For example, fungal plant pathogens are currently an increasing threat to 1755 world food security [164]. A wind-dispersed banana plant fungus (Mycosphaerella fijiensis) field experiment documented $1 \mathrm{~km}$ airborne dispersal in one generation [91]. Studies such as these and others, e.g., [90], together with the above cited plant biology and biosafety literature, demonstrate that the infection probability first decreases quickly with distance which is followed by regimen of kilometer-range LDD events (termed a long "dispersion tail").

1760 In the United States, long-distance airborne spread of economically significant plant disease across the landscape is an ongoing concern. Predictable seasonal airborne pathogen incursion pathways across the continent are well-identified and routinely monitored to protect crop 1763 yields. These continental-scale incursions typically proceed in a stepwise series of shorter (long1764 distance) airborne dispersions. Chief examples are the seasonal airborne south to north US dispersion incursion pathways across the Midwest Great Plains for wheat stem rust (Puccinia graminis f. sp. tritici); the pandemic spread of tobacco blue mold spores (Peronospora tabacina)

1767 across the Eastern US; and the seasonal US airborne invasion of soybean rust (Phakopsora 1768 pachyrhizi Sydow) [89], [93], [159], [165], [166].

1769 In the Veterinary literature there are many examples of probable kilometer-range airborne infection transmission. For example, Newcastle Disease virus, Equine Influenza (A/H3N8), Highly Pathogenic Avian Influenza A(H7N7) are important ongoing diseases and each has evidence for long-range airborne virus transmission [132], [167]-[170]. The best described long distance airborne transmitted disease in animals is Foot and Mouth Disease virus, an economically significant disease of veterinary livestock. Long-distance FMDV aerosols are suspected to have contributed to a number of costly, regional-scale disease outbreaks in Europe, including

1776 airborne transmission from continental Europe to the United Kingdom [171], [172]. This disease 1777 has motivated the significant development and testing of scientific models for long distance 1778 infectious aerosol dispersions with the aim of limiting epidemic spread [58], [160]-[162], [173]1779 [176]. 
medRxiv preprint doi: https://doi.org/10.1101/2020.04.23.20076273; this version posted April 28, 2020. The copyright holder for this preprint (which was not certified by peer review) is the author/funder, who has granted medRxiv a license to display the preprint in perpetuity. It is made available under a CC-BY-NC-ND 4.0 International license .

M Dillon and

C Dillon

Particle Model for Airborne Disease Transmission

1780

1781

1782

1783

1784

1785

1786

1787

1788

1789

1790

1791

1792

1793

1794

1795

1796

1797

1798

1799

1800

1801

1802

1803

1804

1805

1806

1807

1808

1809

1810

1811

1812

1813

1814

1815

In the human epidemiology literature, many well documented examples exist for airborne disease transmissions over distances greater than 1 kilometer downwind. Coxiella burnetii, an endemic disease of ruminants and livestock, is also the cause of $Q$ Fever in humans [59]. Longdistance airborne transmission disease outbreaks from animal farms to human populations have occurred in many European countries [42], [83], [177]-[179]. Notably the recent regionalscale Q Fever epidemic in 2007-2010 in the Netherlands was caused by infectious aerosols emitted from small animal farms [40], [41], [180]-[182]. The epidemic resulted in 4,000 clinical cases and 2,700 hospitalizations [180]. A more recent 2018 follow up of this outbreak showed that among the 519 chronic Q Fever cases identified, 86 patients had died [69]. Legionella pneumophilia dispersions from building cooling towers are also an ongoing source of kilometerrange community Legionnaire's Disease outbreaks despite the introduction of preventive legal regulations for cooling equipment maintenance [142], [183]. Significant airborne Legionnaire's disease outbreaks have been reported in many countries including the US, France, Norway, Sweden, and Spain [43], [44], [137]-[141], [143]-[145], [184], [185].

The fungal pathogens Histoplasma capsulatum and Coccidioides immitis and posadasii cause significant human disease due to inhalation (Histoplasmosis and Coccidioidomycosis [or Valley Fever], respectively). Both are endemic in the US: Histoplasmosis in the Eastern and Midwestern states, Coccidioidomycosis in the American West and Southwest [29], [186]. Based on observational epidemiologic studies, three city-wide airborne outbreaks of Histoplasmosis have occurred, two at a community level [187]-[189] and the third being a series of 3 large outbreaks that occurred in urban Indianapolis, IN [190]-[192].

Coccidioidomycosis occurs after inhalation of fungal spores which are widely distributed in southwestern US soils [193], [194]. Forty percent of exposed persons will have clinical symptoms, ranging from an influenza-like illness to disseminated disease and chronic meningitis. Symptomatic disseminated disease requires aggressive treatment and has increased rates of hospitalization and mortality [195], [196]. Desert dust cloud dispersions containing Coccidioides spores are an important ongoing cause of disease in endemic areas [197]. In addition long-distance airborne dust cloud Coccidioides dispersal events triggered by natural disasters have caused significant regional Coccidioidomycosis outbreaks in the US state of California [198]. Kilometer-scale airborne transmission occurred in the Los Angeles area following the 1994 Northridge earthquake, where strong aftershocks generated landslides on the slopes of the Santa Susana Mountains creating large, contaminated dust clouds [45], [46], [199]. These clouds were blown by ambient winds into the urban Simi Valley and Ventura County areas - causing a Coccidioidomycosis outbreak (203 total cases; 55 hospitalizations; 3 fatalities). 
medRxiv preprint doi: https://doi.org/10.1101/2020.04.23.20076273; this version posted April 28, 2020. The copyright holder for this preprint (which was not certified by peer review) is the author/funder, who has granted medRxiv a license to display the preprint in perpetuity. It is made available under a CC-BY-NC-ND 4.0 International license .

M Dillon and

C Dillon
Particle Model for Airborne Disease Transmission

\section{Continental and Global Range (> $500 \mathrm{~km}$ )}

1817 Continental-scale airborne dispersion events, especially plant seed dispersions, have been well 1818 studied and influence the spread of invasive species, metapopulation dynamics, and plant 1819 diversity [134], [156], [157], [200]. Continental-scale transport of common environmental 1820 bacteria species, either on normal atmospheric air currents or in association with dust cloud dispersions, has also been well-demonstrated [55], [105], [201], [202]. As one example,

1822 bacterial communities from the Saharan desert are known to travel airborne to high European

1823 Alpine lakes [203], [204]. Pathogenic bacteria have also been observed in the ambient 1824 atmosphere, including plant, animal, and human pathogens [205]-[207]. Furthermore, airborne 1825 transmission of Neisseria meningitidis, a major cause of Meningitis world-wide, is currently 1826 under investigation in the endemic Sahel region of North Africa as outbreaks occur most often 1827 in dry months with frequent dust storms [202], [206].

1828 Airborne continental-scale disease spread often proceeds as a series of sequential long range airborne transmission events over the landscape (saltatory transmission). However, individual continental-scale airborne disease transmission events, i.e., a single airborne plume transporting pathogens more than $500 \mathrm{~km}$, are also documented in the literature [54], [89], [208], [209]. Most but not all of the existing examples are from agricultural biosafety studies where these events are termed "single-step" LDD pathogen invasions [54]. These types of events are thought to be rare and often associated with extreme weather events or natural disasters [89], [198]. However, routinely occurring, "single-step" LDD events could be more frequent, although the possibility has not been systematically investigated. For example, a sentinel study LDD of airborne pathogenic plant fungi (Erysiplic graminis, f.sp. hordei [barley mildew] and Erysiplic graminis, f.sp tritici [wheat mildew]) demonstrated transmission over a distance of $650 \mathrm{~km}$ across the North Sea from Great Britain to Scandinavia [209]. Samples were obtained using disease-free receptor plant populations compared to unexposed control plants and a multi-year series of samples were obtained in the highest expected transmission regions.

A major weather-related "single-step" LDD event was the 2,000 km airborne dispersion of Asian soybean rust (Phakopsora pachyrhizi) across the Caribbean from northwestern South America to the US during Hurricane Ivan [89]. This 2004 event marked the invasion of Asian soybean rust into the North American continent. The event was anticipated as the spread of Asian soybean rust from Brazil northward in South America was being monitored and Brazil had lost a significant fraction of its soybean production to this pathogen. Among other measures (and prior to the event itself), predictive atmospheric dispersion modeling for potential transport to the US during tropical cyclone seasons were conducted and the US Department of Agriculture deployed disease forecasting systems and field-tested a detailed response plan for use in the event the soybean rust was identified [89]. Soybean rust was detected infesting soybean fields 
medRxiv preprint doi: https://doi.org/10.1101/2020.04.23.20076273; this version posted April 28, 2020. The copyright holder for this preprint (which was not certified by peer review) is the author/funder, who has granted medRxiv a license to display the preprint in perpetuity. It is made available under a CC-BY-NC-ND 4.0 International license .

M Dillon and C Dillon
Particle Model for Airborne Disease Transmission
1852

in Louisiana (as predicted) within two weeks after Hurricane Ivan had passed. Subsequently Asian soybean rust has remained endemic in many southern states, especially in the initial epidemic outbreak area [210].

A clear human-disease example of single-plume continental-scale airborne disease transmission is the $600 \mathrm{~km}$ dispersion of Coccidioides immitis spores in California which resulted in widespread Coccidioidomycosis outbreaks [211]. In this 1977 event, a $160 \mathrm{~km} \mathrm{~h}^{-1}$ windstorm scoured $15 \mathrm{~cm}$ of Coccidioides immitis contaminated topsoil from Kern County, located in the southernmost basin of California's great central San Joaquin Valley, carrying a resulting dust cloud to an altitude of 1,500 meters (Image, reference [212]). The dust was transported northward and dispersed over a 87,000 $\mathrm{km}^{2}$ area [191], [208], [211], [213] - burying freeways and shutting down interstate transportation. There were 3 immediate storm-related fatalities and 3 firefighters died in a forest fire spread by the strong winds. Sacramento, a low endemicity area $500 \mathrm{~km}$ to the north, experienced a large Coccidioidomycosis outbreak (115 cases and 6 fatalities reported vs. a background incidence of 0 to 6 cases per year). Overall fifteen California counties northward in the dust cloud dispersion area reported a ten-fold increase in Coccidioidomycosis cases and 9 counties reported lesser increases [211]. This 1977 Coccidioides intimus dispersion, with a total of more than 379 new cases, serves as a historical benchmark for the potential magnitude of Coccidioidomycosis cases from a significant dust storm [208]. Integrated Coccidioidomycosis case surveillance and dust storm forecasting are currently standard in US endemic areas [214]. 
medRxiv preprint doi: https://doi.org/10.1101/2020.04.23.20076273; this version posted April 28, 2020. The copyright holder for this preprint (which was not certified by peer review) is the author/funder, who has granted medRxiv a license to display the preprint in perpetuity. It is made available under a CC-BY-NC-ND 4.0 International license .

M Dillon and

C Dillon
Particle Model for Airborne Disease Transmission

\section{4}

1875

1876

\section{Supplemental Material B: Key Atmospheric Transport and Dispersion Modeling Concepts}

Atmospheric physics, as well as atmospheric transport and dispersion models of airborne hazards, are well-established and extensive fields. This supplemental material aims to briefly introduce the reader to key concepts needed for this report. We note that while the theory developed in this study is applicable at a wide range of spatial and temporal scales, the epidemiological datasets that are compared to theoretical predictions relate to exposures that occur near the earth's surface (in the atmospheric boundary layer), from $0.05 \mathrm{~km}$ to a few tens of $\mathrm{km}$ downwind of an airborne release, and less than a few hours from the time of initial release. The interested reader is referred to [215]-[222] for further details of atmospheric air flow physics, dispersion, and modeling including those present at other spatial and temporal scales.

\section{Mean Air Flow in the Atmosphere}

The mean (time-averaged) air flows are driven by a spatial gradient in atmospheric pressure. When the horizontal surface pressure gradient between two locations is a few millibar over a hundred kilometers (tenths of $\mathrm{mb} \mathrm{km}^{-1}$ ), as occurs near the center of a high-pressure weather system; the atmosphere is relatively calm and horizontal surface mean wind speeds are light, typically less than $2 \mathrm{~m} \mathrm{~s}^{-1}$. Larger surface pressure gradients, several to tens of $\mathrm{mb} \mathrm{km}^{-1}$, result in moderate surface winds ( 3 to $7 \mathrm{~m} \mathrm{~s}^{-1}$ ) which are sufficient to stir leaves and twigs. Finally, larger pressure gradients, which can occur during storms, produce strong winds $\left(>8 \mathrm{~m} \mathrm{~s}^{-1}\right)$. The spatial and temporal distribution of wind, i.e., the "wind field," may be quite complex as local topography can steer the direction of local winds. For example, winds can be channeled along river and mountain valleys and within urban streets or be blocked by hills or mountains. 
medRxiv preprint doi: https://doi.org/10.1101/2020.04.23.20076273; this version posted April 28, 2020. The copyright holder for this preprint (which was not certified by peer review) is the author/funder, who has granted medRxiv a license to display the preprint in perpetuity. It is made available under a CC-BY-NC-ND 4.0 International license .

M Dillon and C Dillon
Particle Model for Airborne Disease Transmission

\section{Atmospheric Turbulence}

1901 In addition to the regional (mean) air flow described in the previous paragraph, smaller scale 1902 motions (turbulent eddies) are typically present in the atmosphere. These turbulent motions 1903 are due to two major causes. Mechanically generated turbulent motions are generated by drag 1904 resulting from the wind moving over and around physical objects on the earth's surface. The 1905 largest mechanically generated eddy size is proportional to the height above ground and 1906 obstacle size. Buoyancy generated turbulent motions are generated, for example, when the 1907 solar heating of the earth's surface causes warmer (buoyant) air to rise and be replaced by 1908 colder air. Buoyancy forces can also decrease turbulent motions, for example, when the surface 1909 is cooler than the air. The size of the largest buoyancy generated eddies depends on the 1910 atmospheric conditions and can be up to approximately 4,000 m.

1911 Once generated, atmospheric eddies interact with each other and the earth's surface. These 1912 interactions result in the original eddies breaking into smaller eddies. The original eddy's 1913 (turbulent kinetic) energy is transferred to the smaller eddies. This process continues, 1914 generating successively smaller eddies until the millimeter size eddies dissipate into heat. This 1915 breakdown process results in a well-characterized spectrum of eddy sizes for a given set of 1916 atmospheric and surface conditions. One important consequence is that turbulent motions in 1917 the atmosphere are correlated over shorter distances (and times) and become uncorrelated at 1918 larger distances (and times). Commonly, turbulent motions are correlated on a few minutes 1919 timescale.

For many common atmospheric conditions, atmospheric eddies are at least an order of magnitude smaller (spatially and temporally) than the scales of motion present in the regional 1922 (mean) air flow. This separation provides a natural division of air motions that transport (mean winds) and dilute (turbulent eddies) contaminated air [222]. This separation results in a gap in the atmospheric energy spectra associated with timescales on the order of an hour. 
medRxiv preprint doi: https://doi.org/10.1101/2020.04.23.20076273; this version posted April 28, 2020. The copyright holder for this preprint (which was not certified by peer review) is the author/funder, who has granted medRxiv a license to display the preprint in perpetuity. It is made available under a CC-BY-NC-ND 4.0 International license .

M Dillon and C Dillon
Particle Model for Airborne Disease Transmission

1927 If a small amount of airborne material is added to a mass of air (called an air parcel), its presence will not significantly affect the regional wind, eddies, or other atmospheric properties. ${ }^{33}$ Thus the transport and dilution of these contaminated air parcels can be determined from atmospheric (meteorological) and surface considerations alone and does not depend on properties of the contaminant. Furthermore, the airborne exposure to such dilute materials can be mathematically represented as the sum of the exposure to many simpler releases at specific locations and short time periods (superposition principle). Consequently, insights (and model results) derived for the transport and dilution of single particles released from a single location and time directly contribute to the characterization of more complex 1936 cases.

1937 During transport by ambient winds, dispersion occurs when the turbulent eddies, described in the prior subsection, mix surrounding air with the contaminated air parcel which reduces the contamination concentration in the original air parcel and increases the contamination in neighboring air parcels. Figure B1 shows photographs of this process using point-source smoke aerosol released at a constant rate into a constant airflow. The upper two panels are instantaneous snapshots which clearly demonstrate high moment-to-moment (stochastic) variations in plume concentrations that result from the effect of turbulent eddies. The bottom panel shows a time-lapse photograph of a smoke plume taken over several minutes. This panel shows two important turbulent dispersion regimes: First, near the release, the time-average plume crosswind spread ("width") depends linearly on distance (and time) from the release because the turbulent motions dispersing the plume are correlated with each other. Second, and farther downwind, the plume spread becomes proportional to the square root of distance (time) from the release because the turbulent motions that disperse the contamination are no longer correlated with the motions present at the time of pollutant release to the atmosphere.

1951 The plume crosswind spread increases with increasing averaging time since larger turbulent 1952 motions affect the plume spread at larger averaging times, see Figure B2. In some cases, the 1953 growth rate of the plume width can dramatically slow after the plume outgrows the size of 1954 typical mechanically or buoyancy generated eddies. However, other processes can result in the 1955 plume width continuing to grow, for example, due to differential advection - where different 1956 parts of the plume are blown in different directions and at different speeds by variations in the

${ }^{33}$ The number of particles required to change the behavior of the atmospheric depends on the (a) atmospheric volume of interest, (b) particle size and density, (c) release duration, and (d) ambient wind speed [9]. For context, assuming a light wind $\left(1 \mathrm{~m} \mathrm{~s}^{-1}\right)$ and monodisperse particles as dense as water $\left(1000 \mathrm{~kg} \mathrm{~m}^{-3}\right)$; a $1 \mathrm{~m}^{3}$ release volume can contain at least $10^{16} 0.1 \mu \mathrm{m}$ diameter particles, $10^{13}$ $1 \mu \mathrm{m}$ diameter particles, or $10^{10} 10 \mu \mathrm{m}$ diameter particles without violating this assumption. 
medRxiv preprint doi: https://doi.org/10.1101/2020.04.23.20076273; this version posted April 28, 2020. The copyright holder for this preprint (which was not certified by peer review) is the author/funder, who has granted medRxiv a license to display the preprint in perpetuity. It is made available under a CC-BY-NC-ND 4.0 International license.

M Dillon and

C Dillon

Particle Model for

Airborne Disease Transmission

mean wind. Differential advection can occur under several conditions including, but not limited to, (a) variation of the mean wind with height, (b) regional scale, horizontal, mean wind variability, and (b) variation of the mean wind with time, e.g., diurnal wind cycles. Differential advection effects are not shown in Figures B1 and B2. We note that in the absence of additional loss mechanisms (such as radioactive decay or deposition to the earth's surface), an airborne plume will continue to transport (and dilute) far downwind-indeed plumes of airborne material have been observed on global scales.

Figure B1. Laboratory photographs of plume dispersion (air flows from left to right). The top two frames are show a snapshot of an individual plume at two different times which highlight the effects of the individual eddies. The bottom frame shows a time averaged concentration over several minutes and more clearly highlight the changes in the growth rate of the plume width with time and downwind distance. (Adapted from image provided by Snyder, EPA)

\section{Wind Direction}
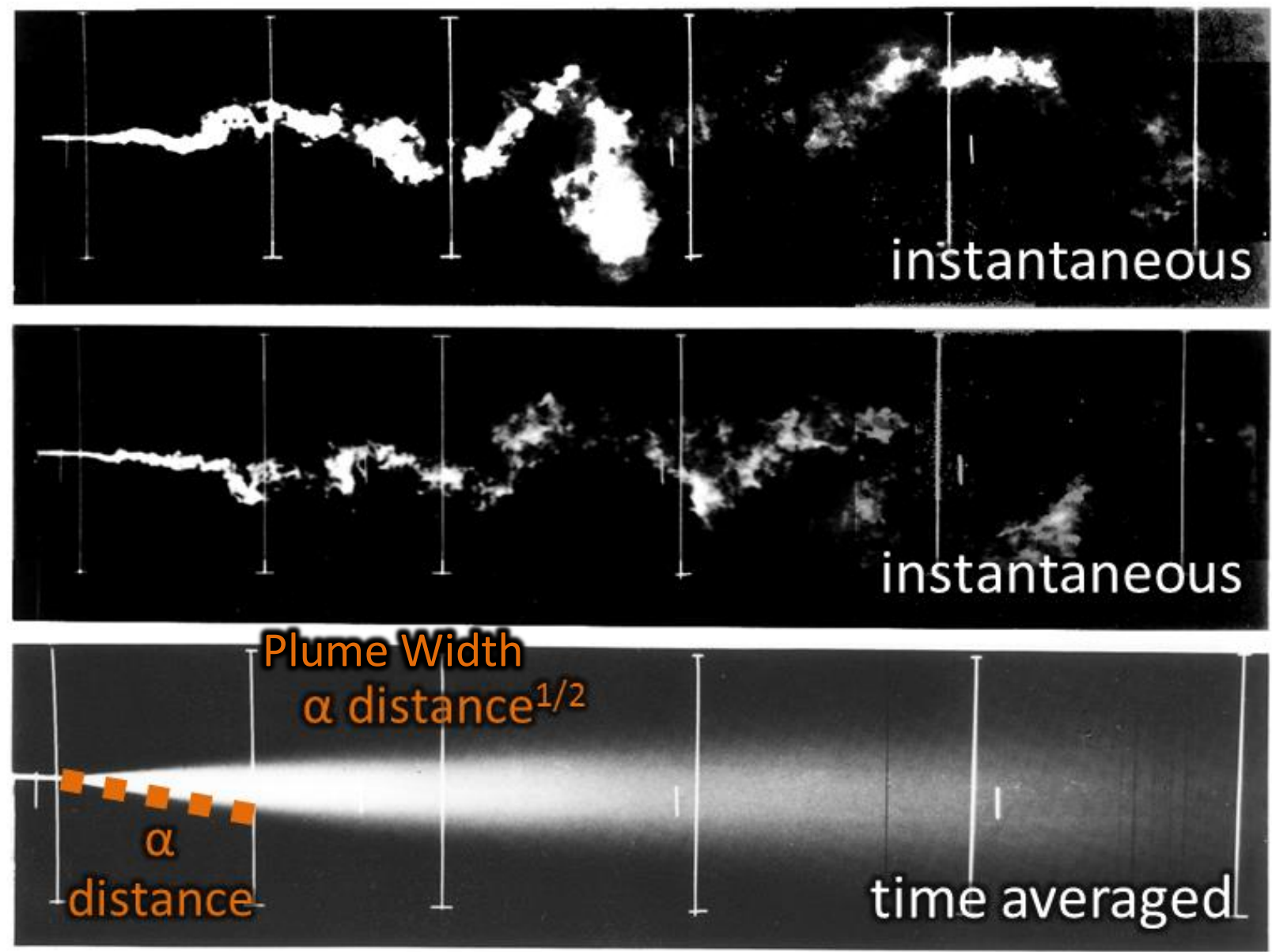
medRxiv preprint doi: https://doi.org/10.1101/2020.04.23.20076273; this version posted April 28, 2020. The copyright holder for this preprint (which was not certified by peer review) is the author/funder, who has granted medRxiv a license to display the preprint in perpetuity. It is made available under a CC-BY-NC-ND 4.0 International license .

M Dillon and C Dillon Particle Model for Airborne Disease Transmission

1972

1973

1974

1975

1976

1977

1978

1979

1980

1981

1982

1983

1984

1985

1986

1987

1988

1989

1990

1991

1992

1993

1994

1995

1996

Figure B2. Illustration of the increase in plume width with averaging time taken from Slade [223]. The left panel shows the nominal plume outline for one of three exemplar averaging time (wind blows along the $x$-axis). The right panel shows the crosswind ( $y$ axis) relative plume concentration at a single, nominal downwind point for the three averaging times considered.

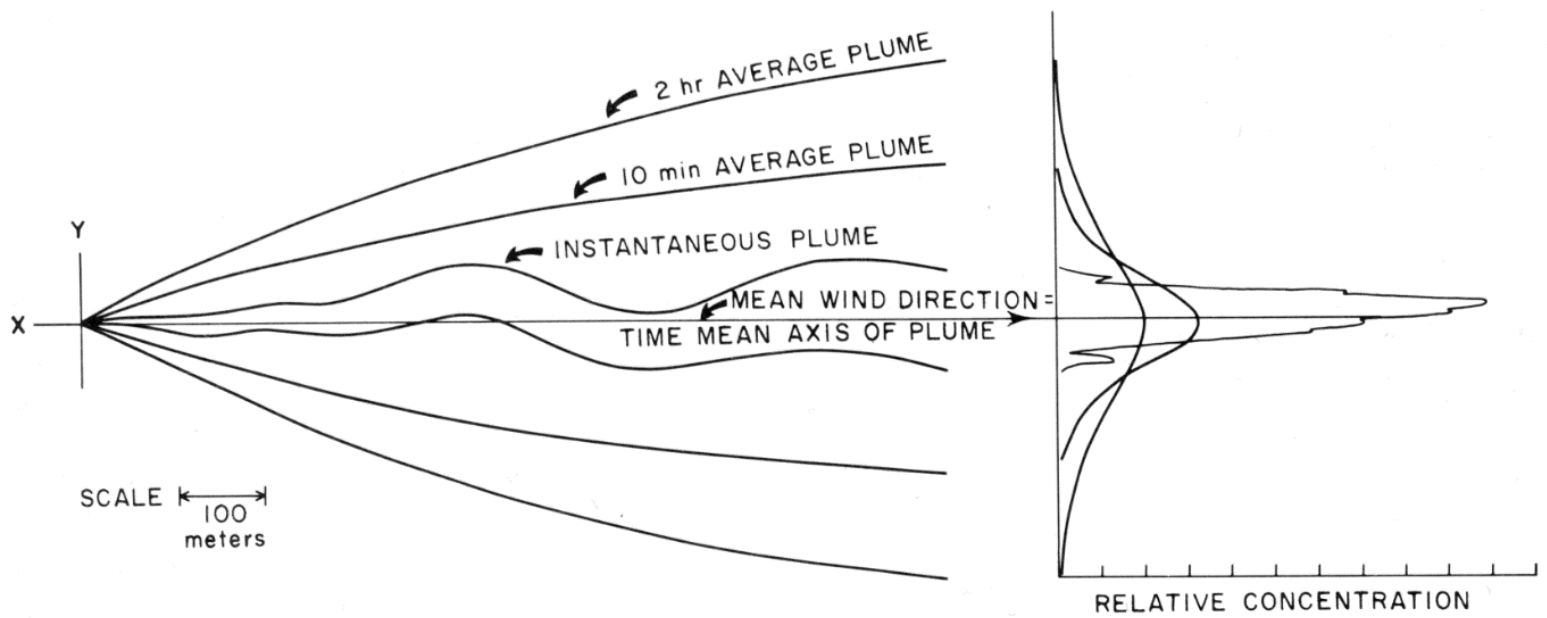

\section{Atmospheric Dispersion Models}

Atmospheric transport and dispersion models simulate the previously discussed physical processes of mean wind transport and turbulent diffusion. Direct Numerical Simulation modeling, which explicitly considers all physical processes, can simulate all relevant air motions and contaminant concentrations, e.g., [224], [225]. However, due to their high computational burden and extensive, and often unavailable, input data requirements, these models are not practical outside a research environment. As such, all practical dispersion models resolve only a portion of the atmospheric motions and physical processes while the effects of the unresolved processes are parameterized, often using statistical descriptions of turbulent motions and fits to empirical data. As a consequence, these model results are inherently statistical in nature and, depending on the model type, predict (a) the ensemble-average (expected value) result (vast majority of models), (b) the distribution of results (concentration fluctuation models), or (c) a single realization from a distribution of possible flows (Computational Fluid Dynamics models using Large Eddy Simulation). Due to their ubiquity and relevance to the theory developed in this paper, we focus here on the ensemble average models. By analogy, the actual plume at any given time is one of the top two panels in Figure B1 while the ensemble average dispersion model is predicting the time-averaged bottom panel (in steady state conditions). 
medRxiv preprint doi: https://doi.org/10.1101/2020.04.23.20076273; this version posted April 28, 2020. The copyright holder for this preprint (which was not certified by peer review) is the author/funder, who has granted medRxiv a license to display the preprint in perpetuity. It is made available under a CC-BY-NC-ND 4.0 International license .

M Dillon and

C Dillon

Particle Model for Airborne Disease Transmission

1998

1999

2000

2001

2002

2003

2004

2005

2006

2007

2008

2009

2010

2011

2012

2013

2014

2015

2016

2017

2018

2019

2020

2021

2022

2023

2024

2025

2026

2027

2028

2029

2030

There are several common types of ensemble average models, including the classic Gaussian plume model, in which downwind concentrations are calculated analytically; Gaussian puff models, in which one or more expanding "puffs" of contaminant are transported downwind; and Lagrangian particle models, in which downwind concentrations are inferred from the Monte Carlo simulations of the trajectories of computational marker particles. ${ }^{34}$ These model types differ in their ability to resolve key spatial and temporal features as well as to describe complex scenarios. The more detailed model types typically have enhanced computational and input data requirements relative to the simpler models. All of these models will produce nearly identical results for basic scenarios and simpler flows (e.g., constant wind speed and direction) in which in the simpler models are valid (and have been validated against experimental data). Gaussian plume models are analytic solutions to transport and diffusion equations for simple conditions are often used as part of the verification process for the more complex numerical models. We note that the scenarios used in this study are closely related to a set of classic, straightforward scenarios and so the modeling results presented in this report are expected to be very similar to those that would be produced by different models.

Atmospheric transport and dispersion models are generally considered to be accurate when they can reproduce individual measurements paired in time and space to within a factor of ten (or better) for a variety of different terrains, downwind distances, and environmental conditions [226], [227]. For example, one modeling system (which is used in this study) is the LLNL ADAPT/LODI diagnostic wind field and Lagrangian particle models [228], [229]. The LLNL ADAPT/LODI models have been validated against a wide range of source terms, environmental conditions, and downwind distances $(0.05$ to $1,500 \mathrm{~km}$ ) [230]-[233]. About $50 \%$ of the modelmeasurement comparisons are (a) within a factor of 2 to 5 for simpler releases (source terms) and environmental conditions and (b) within a factor of 10 for more complex conditions. Most of these validation studies use gas tracers; however one experiment used particulate matter.

When model and measurement data are compared in a way that reduces the importance of stochastic variability, model accuracy can markedly improve. One case is the Quartile-Quartile (Q-Q) plot which is used, in part, to validate operational transport and dispersion models, e.g., [230], [234]. This plot compares distributions of measured and modeled concentration data and does not have the requirement that the model/measurement data is paired in time or space. As one example, when comparing model predictions and measurements from a single tracer study that took place in Copenhagen, $38 \%$ of the point to point comparisons are within a factor of 2 but the Q-Q plot demonstrates much better agreement, see Figure B3 [230]. Another useful

\footnotetext{
${ }^{34}$ These computational marker particles are a large sample from the possible particles emitted and are used in estimating downwind concentrations along the prescribed contaminant emission amount. These particles do NOT directly represent individual physical aerosols.
} 
medRxiv preprint doi: https://doi.org/10.1101/2020.04.23.20076273; this version posted April 28, 2020. The copyright holder for this preprint (which was not certified by peer review) is the author/funder, who has granted medRxiv a license to display the preprint in perpetuity. It is made available under a CC-BY-NC-ND 4.0 International license .

M Dillon and Particle Model for C Dillon Airborne Disease Transmission

metric is integration within respect to time and/or space. For the Copenhagen study, all the model predictions agreed within a factor of 2 of the observed concentrations when integrated along arcs equidistant from the release site (crosswind integrated air concentrations), see Figure B4.

2035

Figure B3. Observed versus predicted ground-level concentrations in the Copenhagen experiment: a) point-by-point comparison, and b) quantile-quantile comparison; only nonzero concentrations included. Dashed line corresponds to geometric mean (0.78) of LODI predicted concentration ( $\left.C_{L O D I}\right)$ to Observed Concentrations $\left(C_{o b s}\right)$. Image adapted from [230].
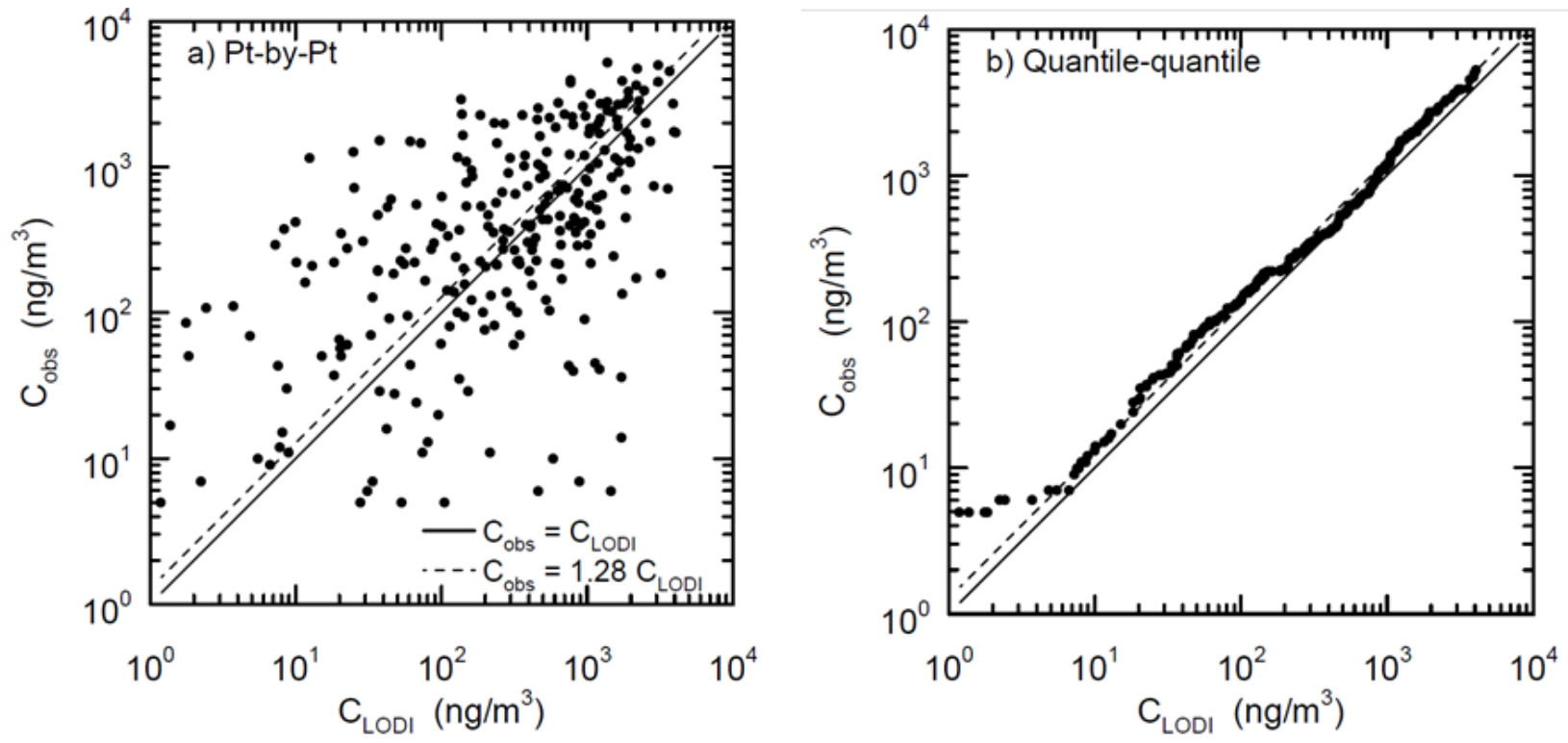

2041

Figure B4. Comparison between observed ( $\left.\mathrm{C}^{\mathrm{y}}{ }_{\mathrm{obs}}\right)$ and predicted $\left(\mathrm{C}^{\mathrm{y}}{ }_{\text {LODI }}\right)$ crosswind-integrated concentration at the surface for all Copenhagen experiments except day 7; dotted lines correspond to factor of 2 over- and under-prediction. Image adapted from [230].

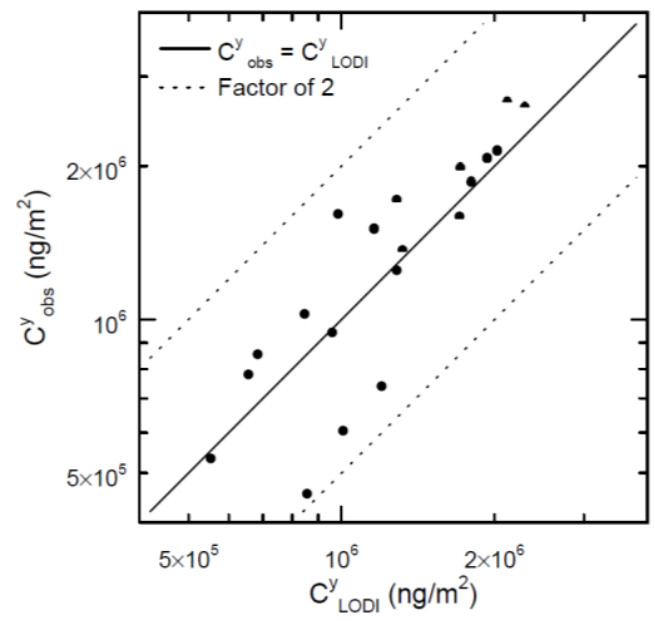


medRxiv preprint doi: https://doi.org/10.1101/2020.04.23.20076273; this version posted April 28, 2020. The copyright holder for this preprint (which was not certified by peer review) is the author/funder, who has granted medRxiv a license to display the preprint in perpetuity. It is made available under a CC-BY-NC-ND 4.0 International license .

M Dillon and C Dillon
Particle Model for Airborne Disease Transmission

\section{Supplemental Material C: General Theory}

2046 In this supplemental material, we derive key theoretical concepts that are implemented in the 2047 main paper. Theoretically, the total number of infections can be calculated by individually 2048 considering every exposed person. However, this approach can be challenging to implement 2049 due to computational considerations, including the need to acquire high resolution input data, 2050 and such approaches potentially obscure useful interpretations. Therefore to facilitate the use 2051 of Equations 1, 2, and $\mathbf{3}$ presented in the main paper, we derive here a series of self-consistent 2052 equations for exposure and infection probability applicable to individuals (indicated by the 2053 index $p$ ), (sub)groups of individuals with the same exposure but varying response to exposure 2054 (index $s$ ), groups of individuals with varying exposures and response to a given exposure (index $2055 \mathrm{~g}$ ), and geographic regions containing a group of people (index $r$ ). 
medRxiv preprint doi: https://doi.org/10.1101/2020.04.23.20076273; this version posted April 28, 2020. The copyright holder for this preprint (which was not certified by peer review) is the author/funder, who has granted medRxiv a license to display the preprint in perpetuity.

It is made available under a CC-BY-NC-ND 4.0 International license .

M Dillon and

C Dillon
Particle Model for Airborne Disease Transmission

\section{Section Variables Definitions}

2058

2059

$r=\mathrm{a}$ specific geographic region

2060

$r_{r e f}=$ a geographic region used as a reference in a relative incidence analysis

2061

$r_{\text {source }}=$ geographic region where infectious airborne particles are emitted

2062

$2063 p=$ an individual person that could be infected (i.e., a susceptible individual)

$2064 T P=$ total number of exposed, susceptible individuals (people)

$2065 s=$ a specific (sub)group of individuals with the same exposure but varying response to that 2066 exposure

$2067 T S=$ total number individuals in (sub)group $s$

$2068 g=$ a specific group of individuals with varying exposures and responses to a given exposure

$2069 T S G=$ total number of subgroups in group $g$

2070

2071 particle type $=$ specifies particle size and infectivity as a function of time and environmental 2072 properties

$2073 b=$ a specific particle type

$2074 T B=$ total number of particle types

2075

2076

[Adjustment Factor $](g, b)=$ scaling factor for group $g$ that accounts for the deviation of $b$ -

2077

2078 type particle exposure and response from that of the reference exposure and response (no units)

2079

[Adjustment Factor] $(r, b)=$ scaling factor for region $r$ that accounts for the deviation of $b$ -

2080 type particle exposure and response from that of the reference exposure and response (no units) 
medRxiv preprint doi: https://doi.org/10.1101/2020.04.23.20076273; this version posted April 28, 2020. The copyright holder for this preprint (which was not certified by peer review) is the author/funder, who has granted medRxiv a license to display the preprint in perpetuity. It is made available under a CC-BY-NC-ND 4.0 International license .

M Dillon and

C Dillon
Particle Model for Airborne Disease Transmission

$[$ Area $](r)=$ area of region $r\left(\mathrm{~m}^{2}\right)$

2084

2085

[Effective Source Term] $\left(r, r_{\text {source }}, b\right)=$ mathematical construct used to scale infection probability from one region to another for $b$-type particles. $\left(\mathrm{m}^{3} \mathrm{~s}^{-1}\right.$ people $\left.\mathrm{e}^{-1}\right)$

[Exposure $](p)=$ number and type of infectious airborne particles in the breathing volume (respiratory second volume) $)^{35}$ of individual $p$ (particles $\mathrm{s} \mathrm{m}^{-3}$ )

[Exposure $](p, b)=$ the number of $b$-type infectious airborne particles in the breathing volume (respiratory second volume) of individual $p$ (particles $\mathrm{s} \mathrm{m}^{-3}$ )

[Exposure $](s, b)=$ number of $b$-type infectious airborne particles in each individual's breathing volume (respiratory second volume) for individuals in (sub)group s (particles s

2095 $\left.m^{-3}\right)$

$[\text { Exposure }]_{\text {ref }}(g, b)=$ reference number of $b$-type airborne particles in the breathing volume (respiratory second volume) of an individual in group $g$ (particles $\mathrm{s} \mathrm{m}^{-3}$ )

$[\text { Exposure }]_{r e f}(r, b)=$ reference number of $b$-type airborne particles in the breathing volume (respiratory second volume) of an individual in region $r$ (particles $\mathrm{s} \mathrm{m}^{-3}$ )

[Exposure Adjustment Factor] $(g, s, b)=$ scaling factor that for group $g$, subgroup $s$ accounts

[Exposure Adjustment Factor] $(r, s, b)=$ scaling factor that for region $r$, subgroup $s$ accounts for the deviation $b$-type particle exposure from the reference exposure (no units)

Health Effect Model $(p,[$ Exposure $](p))=$ mathematical model describing the probability 2106 that an individual $p$ will be infected given the individual's specific exposure (no units)

\footnotetext{
${ }^{35}$ Respiratory minute volume is a traditional unit in pulmonary medicine - this study uses respiratory second volume.
} 
medRxiv preprint doi: https://doi.org/10.1101/2020.04.23.20076273; this version posted April 28, 2020. The copyright holder for this preprint (which was not certified by peer review) is the author/funder, who has granted medRxiv a license to display the preprint in perpetuity. It is made available under a CC-BY-NC-ND 4.0 International license .

M Dillon and

C Dillon
Particle Model for Airborne Disease Transmission

$2108[$ Infection Probability $](p)=$ probability that an individual $p$ becomes infected (no units)

2109 [Infection Probability] $(s)=$ mean probability that a random individual in (sub)group $s$ 2110 becomes infected. All individuals in (sub)group $s$ have the same exposure. (no units)

2111 [Infection Probability] $(g)=$ mean probability that a random individual in group $g$ becomes 2112 infected (no units)

2113 [Infection Probability] $(r)=$ mean probability that a random individual in region $r$ becomes 2114 infected (no units)

[Infection Probability] $(r, b)=$ mean probability that a random individual in region $r$ becomes infected by a $b$-type particle (no units)

[Infections $]=$ total number of people infected (people)

[Infections $](r, b)=$ total number of people infected by $b$-type particles in region $r$ (people)

[Infectious People $]\left(r_{\text {source }}\right)=$ total number of people capable of emitting infectious particles in source region $r_{\text {source }}$ (people)

[Metric of Interest Probability] $(p)=$ probability that an individual $p$ exhibits the metric of interest (no units) and the passage of the airborne infectious plume assuming a single particle was released from source region $r_{\text {source }}\left(\mathrm{s} \mathrm{m}^{-1}\right)$ 
medRxiv preprint doi: https://doi.org/10.1101/2020.04.23.20076273; this version posted April 28, 2020. The copyright holder for this preprint (which was not certified by peer review) is the author/funder, who has granted medRxiv a license to display the preprint in perpetuity. It is made available under a CC-BY-NC-ND 4.0 International license .

M Dillon and

C Dillon

Particle Model for Airborne Disease Transmission

[Population Density $](r)=$ population density in region $r\left(\right.$ people $\mathrm{m}^{-2}$ )

[Population Probability $](g, s)=$ probability that an individual in group $g$ is in subgroup $s$ (no units)

[Relative Infection Probability] $(r, b)=$ ratio of the region $r$ infection probability to reference region infection probability due to exposure to $b$-type particles (no units)

[Release Probability $](b)=$ probability that a particle released into the environment is a $b$ type particle (dimensionless)

[Response Adjustment Factor] $(g, s, b)=$ scaling factor that for group $g$, subgroup $s$ accounts for the deviation of $b$-type particle response from the reference response (no units)

[Single Particle Infection Probability] $(p, b)=$ the probability that individual $p$ will become infected after being exposed to a single $b$-type particle. This term includes the probability that particle(s) will be inhaled and deposit in the respiratory system. $\left(\mathrm{m}^{3} \mathrm{~s}^{-1}\right.$ particle $\left.{ }^{-1}\right)$ individual in (sub)group $s$ will become infected after being exposed to a single $b$-type particle. This term includes the probability that particle(s) will be inhaled and deposit in the respiratory system. $\left(\mathrm{m}^{3} \mathrm{~s}^{-1}\right.$ particle $\left.{ }^{-1}\right)$

[Single Particle Infection Probability $]_{\text {ref }}(g, b)=$ reference probability that an individual in group $g$ will become infected after being exposed to a single $b$-type particle. This term includes the probability that particle(s) will be inhaled and deposit in the respiratory system. $\left(\mathrm{m}^{3} \mathrm{~s}^{-1}\right.$ particle $\left.{ }^{-1}\right)$

[Single Particle Infection Probability $]_{r e f}(r, b)=$ reference probability that an individual in region $r$ will become infected after being exposed to a single $b$-type particle. This term includes the probability that particle(s) will be inhaled and deposit in the respiratory system. $\left(\mathrm{m}^{3} \mathrm{~s}^{-1}\right.$ particle $\left.{ }^{-1}\right)$ 
medRxiv preprint doi: https://doi.org/10.1101/2020.04.23.20076273; this version posted April 28, 2020. The copyright holder for this preprint (which was not certified by peer review) is the author/funder, who has granted medRxiv a license to display the preprint in perpetuity. It is made available under a CC-BY-NC-ND 4.0 International license.

M Dillon and

Particle Model for

C Dillon Airborne Disease Transmission

[Single Particle Metric of Interest Probability] $(p, b)=$ the probability that individual $p$ will exhibit the metric of interest after being exposed to a single $b$-type particle. This term includes the probability that particle(s) will be inhaled and deposit in the respiratory system. $\left(\mathrm{m}^{3} \mathrm{~s}^{-1}\right.$ particle $\left.{ }^{-1}\right)$

[Source Adjustment Factor] $\left(r_{\text {source }}, b\right)=$ scaling factor that accounts for the deviation of $b$ type particles emitted from the $r_{\text {source }}$ region from that of a reference source region (no units)

[Subgroup Adjustment Factor] $(g, s, b)=$ scaling factor that accounts for the deviation of group $g$, subgroup $s, b$-type particle exposure and response from that of the reference (particles) 
medRxiv preprint doi: https://doi.org/10.1101/2020.04.23.20076273; this version posted April 28, 2020. The copyright holder for this preprint (which was not certified by peer review) is the author/funder, who has granted medRxiv a license to display the preprint in perpetuity. It is made available under a CC-BY-NC-ND 4.0 International license.

M Dillon and

Particle Model for

C Dillon Airborne Disease Transmission

Conceptual Model

2180 The general environmentally-mediated infection process can be mathematically represented by 2181 Equations C1 and C2.

$$
[\text { Infections }]=\sum_{p=1}^{T P}[\text { Infection Probability }](p)
$$

\section{Rare Exposures}

2189 If there are TB different types of particles AND any individual inhales either one or no particles, 2190 then the probability of an individual $p$ becoming infected is shown in Equation C3. ${ }^{36}$

$$
\text { [Infection Probability }](p)
$$

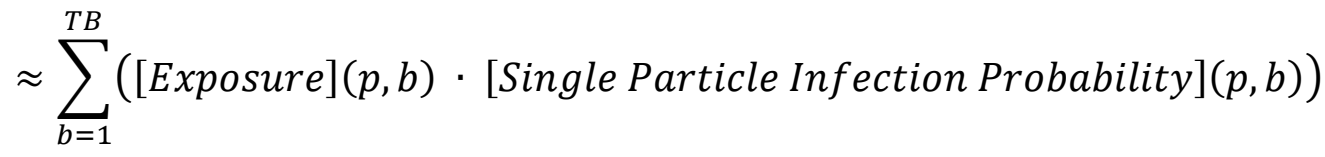

\footnotetext{
${ }^{36}$ For context, an airborne exposure of $10^{4}$ particles $\mathrm{s} \mathrm{m}^{-3}$ would result in a typical individual inhaling a single particle (assuming a breathing rate of $10^{-4} \mathrm{~m}^{3} \mathrm{~s}^{-1}$ [235]).
} 
medRxiv preprint doi: https://doi.org/10.1101/2020.04.23.20076273; this version posted April 28, 2020. The copyright holder for this preprint (which was not certified by peer review) is the author/funder, who has granted medRxiv a license to display the preprint in perpetuity. It is made available under a CC-BY-NC-ND 4.0 International license.

M Dillon and

Particle Model for

C Dillon Airborne Disease Transmission

Subgroups

2197 Consider a (sub)group s comprised of TS individuals with same exposure, but varying response 2198 to that exposure, ${ }^{37}$ then Equations C4 and C5 provides the mean infection probability for 2199 (sub)group s.

${ }^{37}$ One example is a group of people in a room where the air is well mixed. 
medRxiv preprint doi: https://doi.org/10.1101/2020.04.23.20076273; this version posted April 28, 2020. The copyright holder for this preprint (which was not certified by peer review) is the author/funder, who has granted medRxiv a license to display the preprint in perpetuity. It is made available under a CC-BY-NC-ND 4.0 International license.

M Dillon and

Particle Model for

C Dillon Airborne Disease Transmission

Groups

2211 When exposures within a group of people are not constant, ${ }^{38}$ each subgroup can be considered 2212 a separate, constant exposure group and the overall group's (mean) infection probability is

2213 equal to the population weighted average of the individual subgroup infection probabilities, see

2214 Equation C6.

2215

(Equation C6)

2216

$[$ Infection Probability $](g)=\sum_{s=1}^{T S G}\left(\begin{array}{c}{[\text { Population Probability }](g, s)} \\ \cdot[\text { Infection Probability }](s)\end{array}\right)$

2217

$\approx \sum_{b=1}^{T B} \sum_{s=1}^{T S G}\left(\begin{array}{c}{[\text { Population Probability }](g, s)} \\ \cdot[\text { Single Particle Infection Probability }](s, b) \\ \cdot[\text { Exposure }](s, b)\end{array}\right)$

2218

2219

${ }^{38}$ One example is a neighborhood where people are in different buildings that provide varying degrees of protection from an outdoor plume of airborne, infectious particles. 
medRxiv preprint doi: https://doi.org/10.1101/2020.04.23.20076273; this version posted April 28, 2020. The copyright holder for this preprint (which was not certified by peer review) is the author/funder, who has granted medRxiv a license to display the preprint in perpetuity. It is made available under a CC-BY-NC-ND 4.0 International license .

M Dillon and C Dillon Particle Model for Airborne Disease Transmission

2220 We assume that the individual exposures and health effects can be defined as a ratio to a 2221 reference exposure and response, respectively. While these ratios can take any value and vary 2222 by individual, the individual-specific value cannot change. With these assumptions, Equation C6 2223 can be re-written as Equation C7 to C11.

$$
[\text { Infection Probability }](g)=\sum_{b=1}^{T B}\left(\begin{array}{c}
{[\text { Single Particle Infection Probability }]_{\text {ref }}(g, b)} \\
\cdot[\text { Exposure }]_{r e f}(g, b) \\
\cdot[\text { Adjustment Factor }](g, b)
\end{array}\right)
$$

$$
=\frac{[\text { Single Particle Infection Probability }](s, b)}{[\text { Single Particle Infection Probability }]_{\text {ref }}(g, b)}
$$


medRxiv preprint doi: https://doi.org/10.1101/2020.04.23.20076273; this version posted April 28, 2020. The copyright holder for this preprint (which was not certified by peer review) is the author/funder, who has granted medRxiv a license to display the preprint in perpetuity. It is made available under a CC-BY-NC-ND 4.0 International license .

M Dillon and C Dillon

Particle Model for Airborne Disease Transmission

\section{Absolute Infection Probability for Geographic Regions}

2239

2240

2241

2242

Geographic regions, e.g., zip codes and census tracts, are often used when reporting epidemiological data and defining outbreak response zones, e.g., quarantine and/or vaccination. For this case, we define region $r$ as a type of group and Equation $\mathbf{C 7}$ can be rewritten as Equation C12 where the reference exposure is defined by Equation C13.

(Equation C12)

$$
\text { [Infection Probability](r) }
$$
$\approx$ [Total Particles Released]

$$
\times \frac{\sum_{b=1}^{T B}\left(\begin{array}{c}
{[\text { Release Probability }](b)} \\
{[\text { Single Particle Infection Probability }]_{r e f}(r, b)} \\
\cdot[\text { Adjustment Factor }](r, b) \\
{[\text { Normalized TSIAC }](r, b)}
\end{array}\right)}{[\text { Area }](r)}
$$

(Equation C13)

$$
\begin{aligned}
& {[\text { Exposure }]_{\text {ref }}(r, b)} \\
& =\frac{[\text { Total Particles Released }] \cdot[\text { Release Probability }](b) \cdot[\text { Normalized TSIAC }](r, b)}{[\text { Area }](r)}
\end{aligned}
$$

When considering outdoor plumes of infectious particles, we adapt the Regional Shelter Analysis (RSA) methodology to assign each location (subgroup s) a "protection factor" which is defined as the ratio of the outdoor to indoor exposures. As shown in [30], [31]; building protection factors depend only on the building operating conditions, environmental parameters, and the particle type. Thus, for a given particle type, the assigned protection factors are identical to the inverse of the [Exposure Adjustment Factor] $(r, s, b)$ where $[\text { Exposure }]_{r e f}(r, b)$ is the outdoor time-integrated air concentration of $b$-type particles during the passage of the airborne infectious plume over region $r$. 
medRxiv preprint doi: https://doi.org/10.1101/2020.04.23.20076273; this version posted April 28, 2020. The copyright holder for this preprint (which was not certified by peer review) is the author/funder, who has granted medRxiv a license to display the preprint in perpetuity. It is made available under a CC-BY-NC-ND 4.0 International license .

M Dillon and C Dillon

Particle Model for Airborne Disease Transmission

\section{Relative Infection Probability for Geographic Regions}

2261 Given a plume of airborne infectious particles from a single source, then Equation C12 implies

2262 Equation C14 when a single particle type dominates the exposures. Equation C14 does not

2263 depend on the release or the infectivity of individual particles. When the two regions are similar

2264 (e.g., both $r$ and $r_{\text {ref }}$ are residential areas with similar demographics) the adjustment factor ratio 2265 is unity. We demonstrate the utility of Equation C14 in the 4. Results and 5. Discussion sections.

$$
\begin{aligned}
& \text { [Relative Infection Probability }](r, b)=\frac{[\text { Infection Probability }](r, b)}{[\text { Infection Probability }]\left(r_{r e f}, b\right)} \\
& =\left(\frac{[\text { Normalized TSIAC }](r, b)}{[\text { Normalized TSIAC }]\left(r_{r e f}, b\right)}\right) \cdot\left(\frac{[\text { Area }]\left(r_{r e f}\right)}{[\text { Area }](r)}\right) \\
& \cdot\left(\frac{[\text { Adjustment Factor }](r, b)}{[\text { Adjustment Factor }]\left(r_{r e f}, b\right)}\right)
\end{aligned}
$$

\section{Extrapolating Regional Infection Probabilities}

2273

When a clear case of region-to-region airborne disease transmission has been identified and a

2274 single particle type dominates the exposures, Equation C16, derived from Equations C15(a-b), estimates an effective source term for each infectious person in the source region. 
medRxiv preprint doi: https://doi.org/10.1101/2020.04.23.20076273; this version posted April 28, 2020. The copyright holder for this preprint (which was not certified by peer review) is the author/funder, who has granted medRxiv a license to display the preprint in perpetuity. It is made available under a CC-BY-NC-ND 4.0 International license .

M Dillon and C Dillon
Particle Model for Airborne Disease Transmission

$$
\approx \frac{[\text { Infections }]\left(r_{\text {ref }}, b\right)}{[\text { Normalized TSIAC }]\left(r_{\text {ref }}, r_{\text {source } 1}, b\right) \cdot[\text { Population Density }]\left(r_{\text {ref }}\right)}
$$

[Effective Source Term $]\left(r_{\text {ref }}, r_{\text {source } 1}, b\right)$

$$
\equiv \frac{\left(\begin{array}{c}
{[\text { Total Particles Released }] \cdot[\text { Release Probability }](b)} \\
\cdot[\text { Single Particle Infection Probability }]_{\text {ref }}\left(r_{\text {ref }}, b\right) \\
\cdot[\text { Adjustment Factor }]\left(r_{\text {ref }}, b\right)
\end{array}\right)}{[\text { Infectious People }]\left(r_{\text {source } 1}\right)}
$$

Given the effective source term (Equation C16), the infection rates in other regions and times can then be estimated with Equation C17a. Alternately, Equation C17b can be used without the need to calculate the intermediate "effective source" quantity. The new term, the source adjustment factor, is introduced which adjusts for the number of airborne infectious particles emitted, e.g., a reduction in cough-emitted infectious particles due to use of respiratory masks. As with Equation C14, the reference and source regions disease adjustment factor may also be similar, i.e., their ratio may be unity, if buildings and demographics are similar in both source and target regions. 
medRxiv preprint doi: https://doi.org/10.1101/2020.04.23.20076273; this version posted April 28, 2020. The copyright holder for this preprint (which was not certified by peer review) is the author/funder, who has granted medRxiv a license to display the preprint in perpetuity. It is made available under a CC-BY-NC-ND 4.0 International license .

M Dillon and

C Dillon
Particle Model for Airborne Disease Transmission

$$
=\frac{\left(\begin{array}{c}
{[\text { Effective Source Term }]\left(r_{\text {ref }}, r_{\text {source } 1}, b\right)} \\
\cdot[\text { Normalized TSIAC }]\left(r, r_{\text {source } 2}, b\right) \\
\cdot[\text { Infectious People }]\left(r_{\text {source } 2}\right)
\end{array}\right)}{[\text { Area }](r)}
$$

2308 
medRxiv preprint doi: https://doi.org/10.1101/2020.04.23.20076273; this version posted April 28, 2020. The copyright holder for this preprint (which was not certified by peer review) is the author/funder, who has granted medRxiv a license to display the preprint in perpetuity. It is made available under a CC-BY-NC-ND 4.0 International license .

M Dillon and C Dillon
Particle Model for Airborne Disease Transmission

\section{Relationship to Disease and Other Metrics}

2317 The Supplemental Material equations presented up to this point focus on infection probability. 2318 However, not all infections result in disease. In addition, other metrics, such as probability of 2319 needing medical resources, may also be of interest. When the probability of the metric of 2320 interest, e.g., disease, can be linearly related to exposure, see Equation C18, then it is 2321 straightforward to adapt the prior equations for the metric of interest by replacing 2322 [Infection Probabilty] $(p)$ with [Metric of Interest Probability] $(p)$. We note than while 2323 [Single Particle Metric of Interest Probability] $(p, b)$ can take any value and vary by 2324 individual and/or particle type, the value for a specific individual and particle type cannot 2325 change. We note that the adjustment factors can vary by metric.

2326 The relative incidence of multiple metrics of interest, such as infection and disease are the same, 2327 since Equation C14 is unchanged by this substitution.

$$
=\sum_{b=1}^{T B}\left(\begin{array}{c}
{[\text { Exposure }](p, b)} \\
{[\text { Single Particle Probability for Metric of Interest }](p, b)}
\end{array}\right)
$$


medRxiv preprint doi: https://doi.org/10.1101/2020.04.23.20076273; this version posted April 28, 2020. The copyright holder for this preprint (which was not certified by peer review) is the author/funder, who has granted medRxiv a license to display the preprint in perpetuity. It is made available under a CC-BY-NC-ND 4.0 International license .

M Dillon and

Particle Model for

C Dillon Airborne Disease Transmission

\section{Supplemental Material D: Indoor Particle Dynamics}

2333 This supplemental material derives equations to estimate three related, but distinct building properties: (1) the degree to which indoor individuals are exposed to outdoor-origin airborne particulates, (2) the degree to which indoor individuals are exposed to indoor-origin airborne particulates, and (3) the faction of indoor-origin particulates that exit the building and enter the outdoor atmosphere. The first section, building protection, is adapted (with minor edits) from a prior publication [30] which also provides detailed discussion on the relevant indoor particle dynamics and representative estimates for both (a) parameter values (which are also used in the other sections) and (b) protection estimates for US buildings and Census Tracts. The other two subsections, which extend the building protection material, are new.

2342 While we do not discuss prior approaches in detail in this report, we note the Wells-Riley model

2343 which estimated the indoor infection risk to susceptible populations who share the same

2344 building as potentially infectious individuals. The Wells-Riley model also provided quantitative 2345 guidance on the indoor loss rates and ventilation rates required to reduce disease spread [3], 2346 [236]. Later extensions of this model have addressed many of its original limitations. However, 2347 all versions retain the concept of a "quantum of infection" whose definition combines many key 2348 physical properties, including the probability of infection when there is exposure to infectious 2349 particles [237]. 
medRxiv preprint doi: https://doi.org/10.1101/2020.04.23.20076273; this version posted April 28, 2020. The copyright holder for this preprint (which was not certified by peer review) is the author/funder, who has granted medRxiv a license to display the preprint in perpetuity. It is made available under a CC-BY-NC-ND 4.0 International license .

M Dillon and

C Dillon
Particle Model for Airborne Disease Transmission

\section{Section Variables Definitions}

$2353 \lambda_{\text {dep }}($ particle size $)=$ the particle size dependent indoor deposition loss rate $\left(\mathrm{h}^{-1}\right)$

$2354 \lambda_{\text {decay }}=$ the "generic" first-order airborne decay (loss) rate $\left(\mathrm{h}^{-1}\right)$

$2355 \lambda_{\text {in }}=$ the rate at which outdoor airborne particles enters the building - typically via infiltration 2356 or ventilation. Includes losses that occur during transport from outdoor to indoor $\left(\mathrm{h}^{-1}\right)$

$2357 \lambda_{\text {inf }}=$ the air infiltration rate at which air enters a building, i.e., the air change rate $\left(\mathrm{h}^{-1}\right)$

$2358 \lambda_{\text {internal }}=$ the rate at which indoor airborne particles are lost within the building - typically by 2359 deposition to surfaces or by filtration $\left(\mathrm{h}^{-1}\right)$

$2360 \lambda_{\text {out }}=$ the rate at which indoor airborne particles exit the building - typically via exfiltration or $2361 \quad$ ventilation $\left(\mathrm{h}^{-1}\right)$

$2362 \lambda_{T}=$ the total building ventilation rate $=$ sum of the infiltration and mechanical ventilation rates $2363 \quad\left(h^{-1}\right)$

[Building Exit Fraction] = fraction of indoor airborne material that exits the building and enters the outdoor atmosphere. (no units)

2367 [Building Floor Area] $=$ floor area of the building $\left(\mathrm{m}^{2}\right)$

2368 [Building Protection Factor] = ratio of the outdoor to indoor exposure. Similar to sunscreen 2369 and personal protective respirator rating systems, higher protection factor values indicate $2370 \quad$ lower exposures and thus increased protection. (protection factor)

2371 [Building Volume] = volume of the building $\left(\mathrm{m}^{3}\right)$

$2372[\text { Normalized TSIAC }]_{\text {indoor }}=$ indoor time and space integrated air concentration assuming a 2373 unit amount of material is released $\left(\mathrm{s} \mathrm{m}^{-1}\right)$

2374 [Room Height $]=$ height of building occupied space $(\mathrm{m})$

2375 [Total Particles Released] = total number of particles released into the indoor air (particles) 
medRxiv preprint doi: https://doi.org/10.1101/2020.04.23.20076273; this version posted April 28, 2020. The copyright holder for this preprint

(which was not certified by peer review) is the author/funder, who has granted medRxiv a license to display the preprint in perpetuity.

It is made available under a CC-BY-NC-ND 4.0 International license .

M Dillon and

C Dillon

Particle Model for

Airborne Disease Transmission

$2377 C_{\text {Indoor }}(t)=$ the indoor particle air concentration at time $\left.\mathrm{tg} \mathrm{m}^{-3}\right)$

$2378 C_{\text {Outdoor }}(t)=$ the outdoor particle air concentration at time $\mathrm{t}\left(\mathrm{g} \mathrm{m}^{-3}\right)$

$2379 L_{\text {inf }}($ particle size $)=$ the particle size dependent efficiency by which particles can penetrate 2380 the building shell (dimensionless)

$2381 L_{\text {out }}$ (particle size $)=$ the particle size dependent efficiency by which particles in indoor air exit 2382 the building through cracks and other penetrations in the building shell (dimensionless)

$2383 F_{\text {filter }}($ particle size $)=$ the particle size dependent filtration efficiency (dimensionless)

$2384 F_{o a}=$ the fraction of outdoor air passing through the HVAC supply fan (dimensionless)

$2385 F_{r, f a n}=$ the fraction of time the forced air furnace recirculation fan is on, i.e., the fan's duty

$2386 \quad$ cycle (dimensionless)

$2387 r_{f a n}=$ the rate at which a building volume of air recirculates through the furnace systems when 2388 the fan is on $\left(\mathrm{h}^{-1}\right)$

$2389 v_{f a n}=$ the rate at which a ventilation or HVAC supply fan delivers air to the building when the 2390 fan is on and combines the outside and recirculation air rates (building volume $\mathrm{h}^{-1}$ )

$2391 \quad t=$ time $(\mathrm{h})$

$2392 \tau=$ an integration variable $(\mathrm{h})$ 
medRxiv preprint doi: https://doi.org/10.1101/2020.04.23.20076273; this version posted April 28, 2020. The copyright holder for this preprint (which was not certified by peer review) is the author/funder, who has granted medRxiv a license to display the preprint in perpetuity. It is made available under a CC-BY-NC-ND 4.0 International license .

M Dillon and C Dillon

Particle Model for Airborne Disease Transmission

2395 Indoor individuals can be exposed to particles of outdoor origin when these contaminants enter 2396 buildings through mechanical ventilation, e.g., heating, ventilation and air conditioning (HVAC) systems, natural ventilation (e.g., open windows), and/or infiltration (e.g., exterior wall cracks).

2398 Particles may also be transported into buildings via deposition on outdoor surfaces or fomites 2399 that are subsequently tracked indoors by individuals, or otherwise transported, into the 2400 building and then resuspended into the indoor air. These transport pathways are illustrated in the top panel of Figure D1. Once indoors, airborne particles can be removed from the indoor air 2402 through (a) air leaving the building through mechanical or natural ventilation and exfiltration;

2403 (b) active filtration within ventilation systems (if present); (c) deposition on indoor surfaces 2404 (some particles may resuspend); and (d) other processes, including radioactive decay, chemical 2405 reactions, stand-alone indoor air filtration systems, and the loss of infectivity of airborne 2406 infectious agents, among others. The latter three loss terms are illustrated in the bottom panel 2407 of Figure D1.

2408 Modeling indoor contaminant concentrations requires choosing among a variety of models with 2409 increasing complexity, ranging from simple single-compartment models to multizone models to 2410 highly detailed computational fluid dynamics models. While increasingly detailed and complex 2411 models may reduce modeling conservatism and uncertainty, the number and fidelity of the 2412 input parameters also increases (see [238] for a general discussion). Detailed parameters are 2413 not generally available for many buildings of interest therefore we make two key modeling 2414 assumptions: (a) that indoor volumes can be represented as a single compartment, which can 2415 be used to describe the time evolution of indoor contaminant concentrations, and (b) that 2416 concentrations within that single compartment are spatially uniform [36], [119], [239], [240]. ${ }^{39}$

${ }^{39}$ We note that the contaminants of concern here are from the outdoors which, due to the air change mechanisms, can result in a relatively uniform indoor spatial contaminant distribution. For example in modeling indoor concentrations of outdoor ozone, Hayes [241] demonstrated that the indoor/outdoor ozone concentration ratio was insensitive to the degree of indoor mixing in both single- and multicompartment models for residences and office buildings. For context, the mixing time constants for both buoyant and mechanical flow conditions in laboratory studies of room mixing are short, $10 \mathrm{~min}$ to $<1 \mathrm{~h}$, compared to the exposure times of interest [35], [36]. 
medRxiv preprint doi: https://doi.org/10.1101/2020.04.23.20076273; this version posted April 28, 2020. The copyright holder for this preprint (which was not certified by peer review) is the author/funder, who has granted medRxiv a license to display the preprint in perpetuity.

It is made available under a CC-BY-NC-ND 4.0 International license .

M Dillon and

C Dillon
Particle Model for

Airborne Disease Transmission

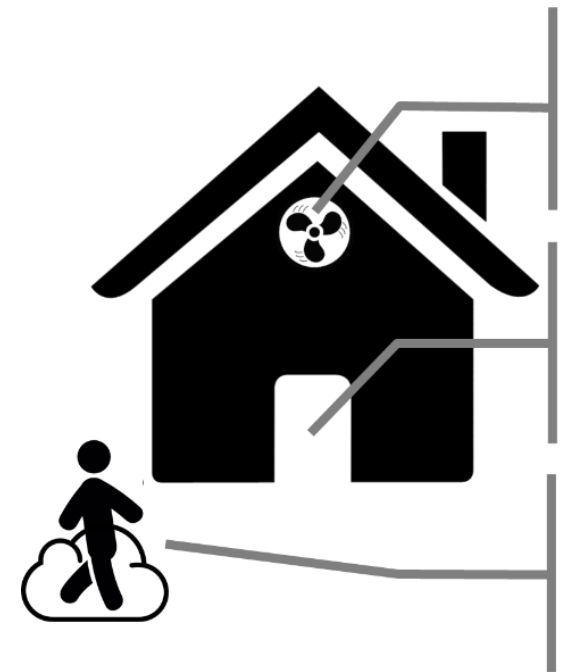

Mechanical air exchange includes HVAC systems and ventilation (exhaust) fans

Natural air exchange includes infiltration and exfiltration through windows, doors, and walls

Fomite transport includes people, animals, and objects

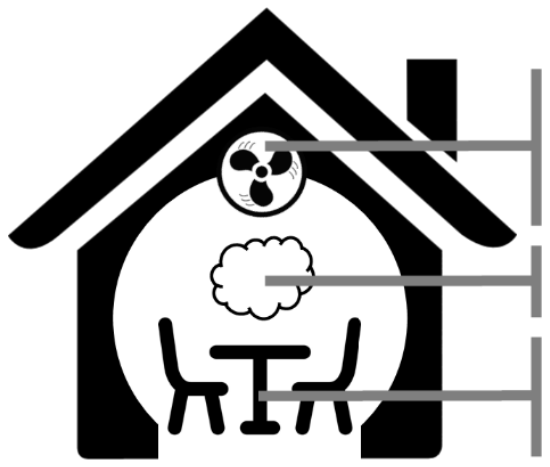

Losses within the heating and cooling system Other losses Deposition to indoor surfaces

Figure D1. Illustrations of (top) mechanisms by which airborne material and fomites can travel between the outdoor and indoor environments and (bottom) indoor loss mechanisms. These assumptions are codified in the single box model (Equation D1a) which can be used to describe the time evolution of indoor air concentrations after outdoor contaminants have entered a given building. This study includes the additional, commonly used assumption that the transport and loss terms, i.e., the $\lambda$ parameters, are independent of both time and air concentration on the timescales of interest. Equation D1a thus reduces to Equation D1b. Derivations provided in the methodology report [31] demonstrate that Equation D2 provides the building protection factor (the ratio of outdoor to indoor exposure). ${ }^{40}$

${ }^{40}$ These equations assume that $(a)$ initial $(t=0)$ indoor air concentrations are zero and $(b)$ material removed from the indoor air is not reintroduced at a later time (e.g., resuspension of deposited particles). 
medRxiv preprint doi: https://doi.org/10.1101/2020.04.23.20076273; this version posted April 28, 2020. The copyright holder for this preprint (which was not certified by peer review) is the author/funder, who has granted medRxiv a license to display the preprint in perpetuity. It is made available under a CC-BY-NC-ND 4.0 International license .

M Dillon and C Dillon
Particle Model for Airborne Disease Transmission

$$
\frac{d C_{\text {Indoor }}}{d t}=\lambda_{\text {in }} \cdot C_{\text {outdoor }}(t)-\left(\lambda_{\text {out }}+\lambda_{\text {internal }}\right) \cdot C_{\text {Indoor }}(t)
$$

$$
C_{\text {Indoor }}(t)=\lambda_{\text {in }} \cdot \int_{0}^{t} C_{\text {Outdoor }}(\tau) \cdot e^{-\left(\lambda_{\text {out }}+\lambda_{\text {internal }}\right)(t-\tau)} d \tau
$$

$$
[\text { Building Protection Factor }]=\frac{\int C_{\text {Outdoor }}(t) d t}{\int C_{\text {Indoor }}(t) d t}=\frac{\left(\lambda_{\text {out }}+\lambda_{\text {internal }}\right)}{\lambda_{\text {in }}}
$$

We adapt Equation D2 to develop two generalized building PF equations to cover the range of building types typically found in the US. The equation terms are grouped to correspond to the $\lambda_{\text {in }}, \lambda_{\text {out }}$, and $\lambda_{\text {internal }}$ terms in Equation D2. Each PF equation is based on one of two common combinations of (a) the three airflow mechanisms described above and (b) the relevant indoor loss mechanisms. In addition to any filtration that might be present, and already incorporated

2443 into the airflow terms, we consider two additional indoor loss mechanisms: (1) deposition of

2444 airborne particles to indoor surfaces, $\lambda_{d e p}$, and (2) a generic first-order airborne loss

2445 mechanism, $\lambda_{\text {decay }}$, which can be used to represent radioactive decay (radiological hazards) or 2446 airborne loss of infectivity (biological hazards). Several parameters are particle size dependent.

2447 For readability, these dependencies are not shown in the equations themselves, but are noted 2448 in the variable list definitions above. See [30] for a detailed discussion of parameters and their common values. 
medRxiv preprint doi: https://doi.org/10.1101/2020.04.23.20076273; this version posted April 28, 2020. The copyright holder for this preprint (which was not certified by peer review) is the author/funder, who has granted medRxiv a license to display the preprint in perpetuity. It is made available under a CC-BY-NC-ND 4.0 International license .

M Dillon and C Dillon

Particle Model for Airborne Disease Transmission

2451 Equation D3 specifies the protection factor for buildings with filtered recirculation. In the US, 2452 these are typically residences. Outdoor airborne material enters the building only through the 2453 infiltration pathway. The forced air furnace recirculation air filter, if present, removes indoor 2454 airborne particles.

$$
[\text { Building Protection Factor }]=\frac{\lambda_{\text {inf }}+\left(F_{\text {filter }} \cdot F_{r, \text { fan }} \cdot r_{\text {fan }}+\lambda_{\text {dep }}+\lambda_{\text {decay }}\right)}{\left(\lambda_{\text {inf }} \cdot L_{\text {inf }}\right)}
$$

Equation D4 specifies the protection factor for buildings with an active HVAC system. In the US, these are typically commercial buildings. Outdoor airborne material enters the building through either infiltration or the HVAC system outdoor air intake. The HVAC system air filter removes airborne particles from both the entering and recirculating air. This equation implicitly assumes

2462 that the HVAC system is always moving building air although not necessarily heating or cooling 2463 it, i.e., the fan duty cycle is $100 \%$.

$$
[\text { Building Protection Factor }]=\frac{\lambda_{T}+\left(F_{\text {filter }} \cdot v_{f a n} \cdot\left(1-F_{o a}\right)+\lambda_{\text {dep }}+\lambda_{\text {decay }}\right)}{\left(\lambda_{\text {inf }} \cdot L_{\text {inf }}+v_{f a n} \cdot F_{o a} \cdot\left(1-F_{\text {filter }}\right)\right)}
$$


medRxiv preprint doi: https://doi.org/10.1101/2020.04.23.20076273; this version posted April 28, 2020. The copyright holder for this preprint (which was not certified by peer review) is the author/funder, who has granted medRxiv a license to display the preprint in perpetuity. It is made available under a CC-BY-NC-ND 4.0 International license.

M Dillon and

C Dillon
Particle Model for

Airborne Disease Transmission

2469 With the additional assumptions that outdoor concentrations are zero and all indoor emissions 2470 occur at a single time $(t=0)$, Equation D1a simplifies to Equations D5(a-b). When a unit

2471 amount of material is released at $t=0$, Equation D5 reduces to Equation D6.

$$
\frac{d C_{\text {Indoor }}(t)}{d t}=-\left(\lambda_{\text {out }}+\lambda_{\text {internal }}\right) \cdot C_{\text {Indoor }}(t)
$$

$$
[\text { Normalized TSIAC }]_{\text {indoor }}=[\text { Building Floor Area }] \cdot \int_{0}^{\infty} C_{\text {Indoor }}(t) d t
$$$$
=[\text { Building Floor Area }] \times\left(\frac{1}{[\text { Building Volume }]}\right) \times\left(\lambda_{\text {out }}+\lambda_{\text {internal }}\right)^{-1}
$$

$$
=\frac{1}{[\text { Room Height }] \cdot\left(\lambda_{\text {out }}+\lambda_{\text {internal }}\right)}
$$


medRxiv preprint doi: https://doi.org/10.1101/2020.04.23.20076273; this version posted April 28, 2020. The copyright holder for this preprint (which was not certified by peer review) is the author/funder, who has granted medRxiv a license to display the preprint in perpetuity. It is made available under a CC-BY-NC-ND 4.0 International license.

M Dillon and

Particle Model for

C Dillon

Airborne Disease Transmission

2482 We now adapt the general building protection equations to estimate the

2483 [Normalized TSIAC $]_{\text {indoor }}$. The equation terms are grouped to correspond to the $\lambda_{\text {out }}$ and

$2484 \lambda_{\text {internal }}$ terms in Equation D6.

2485

2486 Equation D7 specifies [Normalized TSIAC] $]_{\text {indoor }}$ for buildings with filtered recirculation (US

2487 residences).

(Equation D7)

2489

$[\text { Normalized TSIAC }]_{\text {indoor }}$

2490

$=\frac{1}{[\text { Room Height }] \cdot\left(\lambda_{\text {inf }}+\left(F_{\text {filter }} \cdot F_{r, f a n} \cdot r_{\text {fan }}+\lambda_{\text {dep }}+\lambda_{\text {decay }}\right)\right)}$

2491

2492

2493 Equation D8 specifies [Normalized TSIAC $]_{\text {indoor }}$ for buildings with an active HVAC system (US commercial buildings).

$[\text { Normalized TSIAC }]_{\text {indoor }}$

$$
=\frac{1}{[\text { Room Height }] \cdot\left(\lambda_{T}+\left(F_{\text {filter }} \cdot v_{\text {fan }} \cdot\left(1-F_{\text {oa }}\right)+\lambda_{\text {dep }}+\lambda_{\text {decay }}\right)\right)}
$$


medRxiv preprint doi: https://doi.org/10.1101/2020.04.23.20076273; this version posted April 28, 2020. The copyright holder for this preprint (which was not certified by peer review) is the author/funder, who has granted medRxiv a license to display the preprint in perpetuity. It is made available under a CC-BY-NC-ND 4.0 International license .

M Dillon and

C Dillon
Particle Model for

Airborne Disease Transmission

\section{Fraction of Indoor Airborne Particles Released to the Outdoors}

2500

2501

2502

2503

2504

2505

2506

2507

2508

2509

2510

2511

2512

2513

2514

2515

2516

2517

2518

2519

2520

2521

2522

2523

2524

Equation D9 shows the fraction of indoor airborne material that exits the building and enters the outdoor atmosphere. This equation is based on (a) the (normalized) indoor concentration, (b) the rate at which indoor air (and airborne material) leaves the building, and (c) particulate losses that occur while airborne particles are suspended in indoor air exiting the building.

(Equation D9)

$$
\begin{aligned}
& {[\text { Building Exit Fraction }]=\frac{\int_{0}^{\infty}\left(C_{\text {Indoor }}(t) \cdot[\text { Building Volume }]\right) \cdot\left(\lambda_{\text {out }} \cdot L_{\text {out }}\right) d t}{[\text { Total Particles Released }]}} \\
& =[\text { Normalized TSIAC }]_{\text {indoor }} \cdot[\text { Room Height }] \cdot \lambda_{\text {out }} \cdot L_{\text {out }} \\
& =\frac{\lambda_{\text {out }} \cdot L_{\text {out }}}{\left(\lambda_{\text {out }}+\lambda_{\text {internal }}\right)}
\end{aligned}
$$

For buildings with filtered recirculation (US residences), outdoor air enters the building only through the infiltration pathway and so $\lambda_{\text {out }}=\lambda_{\text {inf }}$ and Equation D10 shows the fraction of material released indoors that exits the building. The entrance and exit airflow paths may differ. For examples, outdoor air could enter the building through wall cracks while some of the indoor air could exit the building through exhaust fans. Thus, entrance and exit loss fractions, $L_{i n}$ and $L_{\text {out }}$, respectively, can in theory differ. However at a practical level, there is little data on which to estimate the $L_{\text {out }}$ term. In addition, small, e.g., $1 \mu \mathrm{m}$ aerodynamic diameter, particle losses are minimal. Therefore we assume $L_{\text {out }}=L_{\text {inf }}$ and the [Exit Fraction] is equal to the inverse of the building protection factor as derived in [30]. For context, 35\%, on average, of the airborne, $1 \mu \mathrm{m}$ aerodynamic diameter, stable (do not lose infectivity in the air) particles released in US single family homes are expected to exit the building (and be released to the outdoor atmosphere) [30].

(Equation D10)

$$
\begin{gathered}
\text { [Building Exit Fraction }]=\frac{\lambda_{\text {inf }} \cdot L_{\text {inf }}}{\lambda_{\text {inf }}+\left(F_{\text {filter }} \cdot F_{r, f a n} \cdot r_{\text {fan }}+\lambda_{\text {dep }}+\lambda_{\text {decay }}\right)} \\
=\frac{1}{[\text { Building Protection Factor }]} \cdot\left(\frac{L_{\text {out }}}{L_{\text {inf }}}\right)
\end{gathered}
$$


medRxiv preprint doi: https://doi.org/10.1101/2020.04.23.20076273; this version posted April 28, 2020. The copyright holder for this preprint (which was not certified by peer review) is the author/funder, who has granted medRxiv a license to display the preprint in perpetuity. It is made available under a CC-BY-NC-ND 4.0 International license.

M Dillon and

Particle Model for

C Dillon Airborne Disease Transmission

2525 For buildings with an active HVAC system (US commercial buildings), indoor airborne material 2526 exits the building through either infiltration or through mechanical means, e.g., the HVAC 2527 system exhaust. Again we note that the entrance and exit airflow paths may differ, but as a 2528 practical matter assume (a) that they are the same $\left(\lambda_{\text {out }}=\lambda_{\text {inf }} ; L_{\text {out }}=L_{\text {inf }}\right)$ and (b) no 2529 particles are lost while the indoor air is exiting through the exhaust system. Equation D11, 2530 which shows the fraction of material released indoors that exits the building, is not the same as 2531 the building protection factor derived in [30].

$[$ Building Exit Fraction $]=\frac{\left(\lambda_{\text {inf }} \cdot L_{\text {inf }}+v_{\text {fan }} \cdot F_{\text {oa }}\right)}{\lambda_{T}+\left(F_{\text {filter }} \cdot v_{\text {fan }} \cdot\left(1-F_{o a}\right)+\lambda_{\text {dep }}+\lambda_{\text {decay }}\right)}$ 
medRxiv preprint doi: https://doi.org/10.1101/2020.04.23.20076273; this version posted April 28, 2020. The copyright holder for this preprint (which was not certified by peer review) is the author/funder, who has granted medRxiv a license to display the preprint in perpetuity. It is made available under a CC-BY-NC-ND 4.0 International license .

M Dillon and

C Dillon
Particle Model for

Airborne Disease Transmission
2536

2537

2538

2539

2540

2541

2542

2543

2544

2545

2546

2547

2548

2549

2550

2551

2552

2553

2554

2555

2556

2557

2558

2559

2560

2561

2562

2563

\section{Supplemental Material E: Outdoor Normalized Time and Space Integrated Air Concentrations}

Outdoor normalized time and space integrated air concentration (Normalized TSIAC) values are a key component in our estimation of the single particle atmospheric transmission rates discussed in the main text. In this Supplemental Material, we describe how these values were calculated. For context, we also provide absolute and relative infection probabilities for a wider range of input parameter values than discussed in the main text.

We use the Lawrence Livermore National Laboratory Atmospheric Data Assimilation and Parameterization Techniques (ADAPT) and Lagrangian Operational Dispersion Integrator (LODI) meteorological and atmospheric dispersion models to calculate outdoor normalized time and space integrated air concentrations [242], [243]. The LODI/ADAPT model accuracy and validation are discussed in Supplemental Material B: Key Atmospheric Transport and Dispersion Modeling Concepts, Atmospheric Dispersion Models section.

We consider a suite of atmospheric conditions, Table E1, which were chosen to span a reasonably wide, but not comprehensive, range of common atmospheric conditions. The atmospheric conditions were held constant during the plume passage. Following this table, we provide the methodology and specific modeling assumptions used.

Tables E2(a-b) to E5(a-b) provide the predicted outdoor Normalized TSIAC as a function of distance from an emission source, atmospheric conditions, and airborne loss rate. The Normalized TSIAC values are specified for both discs and circle arcs at distances ranging from 50 $\mathrm{m}$ to $20 \mathrm{~km}$. Each table corresponds to one airborne (infectivity) loss rate $\left(0,0.1,1\right.$, or $10 \mathrm{~h}^{-1}$ loss rates were modeled). Each table column corresponds to 1 of 7 commonly encountered wind speeds and atmospheric stabilities as specified in Table E1.

For context, Figures E1 to E4 provide downwind, upper bound estimates for two cases: (a) the average per-person, single particle, absolute infection probability and (b) the corresponding urban area infections. Figures E5 to E8 provide relative infection probabilities relative to $1 \mathrm{~km}$ disc or arc values. Each figure corresponds to a single airborne (infectivity) loss rate. 
medRxiv preprint doi: https://doi.org/10.1101/2020.04.23.20076273; this version posted April 28, 2020. The copyright holder for this preprint (which was not certified by peer review) is the author/funder, who has granted medRxiv a license to display the preprint in perpetuity. It is made available under a CC-BY-NC-ND 4.0 International license.

M Dillon and Particle Model for

C Dillon Airborne Disease Transmission

2564 Table E1. Summary of modeled atmospheric conditions

\begin{tabular}{|c|c|c|c|}
\hline $\begin{array}{l}\text { Qualitative } \\
\text { Description }\end{array}$ & $\begin{array}{c}\text { Stability Class } \\
\text { (MO Length in } \mathrm{m} \text { ) }\end{array}$ & $\begin{array}{l}\text { Wind Speed at } 10 \mathrm{~m} \\
\text { above ground level } \\
\text { in } \mathrm{m} \mathrm{s}^{-1}\end{array}$ & $\begin{array}{c}\text { Boundary Layer } \\
\text { Height in } \mathrm{m}\end{array}$ \\
\hline $\begin{array}{l}\text { Clear, cold night with } \\
\text { light winds }\end{array}$ & $\begin{array}{c}F \\
(25)\end{array}$ & 1.0 & 300 \\
\hline $\begin{array}{c}\text { Clear night } \\
\text { with gentle breeze }\end{array}$ & $\begin{array}{c}E \\
(50)\end{array}$ & 4.5 & 500 \\
\hline $\begin{array}{c}\text { Overcast } \\
\text { with light winds }\end{array}$ & $\begin{array}{c}C \\
(-50)\end{array}$ & 1.0 & 1,000 \\
\hline $\begin{array}{c}\text { Overcast } \\
\text { with gentle breeze }\end{array}$ & $\begin{array}{c}D \\
(\infty)\end{array}$ & 4.5 & 800 \\
\hline $\begin{array}{c}\text { Overcast } \\
\text { with strong breeze }\end{array}$ & $\begin{array}{c}D \\
(\infty)\end{array}$ & 10 & 800 \\
\hline $\begin{array}{c}\text { Clear day } \\
\text { with gentle breeze }\end{array}$ & $\begin{array}{c}B \\
(-25)\end{array}$ & 4.5 & 1,200 \\
\hline $\begin{array}{l}\text { Clear, hot day } \\
\text { with light winds }\end{array}$ & $\begin{array}{c}A \\
(-10)\end{array}$ & 1.0 & 1,500 \\
\hline
\end{tabular}


medRxiv preprint doi: https://doi.org/10.1101/2020.04.23.20076273; this version posted April 28, 2020. The copyright holder for this preprint (which was not certified by peer review) is the author/funder, who has granted medRxiv a license to display the preprint in perpetuity. It is made available under a CC-BY-NC-ND 4.0 International license .

M Dillon and

C Dillon
Particle Model for Airborne Disease Transmission

We modeled the downwind impacts assuming:

- The release quantity is one (effective) particle.

- All particles have $1 \mu \mathrm{m}$ aerodynamic diameter.

2569

- The released particle has a constant probability of being emitted from a point within a $1 \mathrm{hr}$ period.

- Gravitational settling is the only deposition mechanism considered. The inclusion of other deposition mechanisms including (but not limited to) Brownian diffusion, rainout, impaction, and interception would all serve to reduce the modeled air concentrations and so our neglect of these mechanisms is consistent with the intent of providing an upper bound on the number of downwind infections.

- 4 different $1^{\text {st }}$ order airborne loss rates (in addition to gravitational settling) are considered: $0,0.1,1$, and $10 \mathrm{~h}^{-1}$. These airborne loss rates are used to characterize the effects of airborne loss of particle infectivity.

- Resuspension (the re-emission of deposited material back into the atmosphere) is neglected.

- Flat terrain with a surface roughness of $0.1 \mathrm{~m}$ corresponding to a suburban setting. In forested and downtown regions, the earth's surface is typically rougher resulting in lower surface air concentrations during stable and neutral atmospheric conditions.

- The modeled wind blew from the west $\left(270^{\circ}\right)$ to the east with no vertical or horizontal variation in wind direction (modeled wind speeds increase with height above ground). 
medRxiv preprint doi: https://doi.org/10.1101/2020.04.23.20076273; this version posted April 28, 2020. The copyright holder for this preprint (which was not certified by peer review) is the author/funder, who has granted medRxiv a license to display the preprint in perpetuity. It is made available under a CC-BY-NC-ND 4.0 International license .

M Dillon and C Dillon Particle Model for Airborne Disease Transmission

Downwind concentrations were predicted using 2 modeling grids. The first had a $30 \mathrm{~km}$ horizontal extent and $100 \mathrm{~m}$ horizontal resolution grid cells. The second had a $1.5 \mathrm{~km}$ horizontal

2592 extent and $6 \mathrm{~m}$ horizontal resolution grid cells

2593 For each case, LODI was run with 1,000,000 marker particles ${ }^{41}$ to calculate the (ensemble) 2594 average surface (lowest $20 \mathrm{~m}$ ) normalized air concentrations integrated over the entire plume 2595 passage (i.e., until no marker particles remain in the modeling domain) for each model grid cell. 2596 For each atmospheric condition, the following procedure was used to calculate the normalized 2597 space and time integrated air concentration provided in Tables E2(a-b) to E5(a-b).

First, we developed an interpolation function for each modeling grid using the MATLAB griddedInterpolant function configured to return either the value at the nearest sample grid point to the requested location (if the requested location is within the sample grid) or zero (if the requested location is outside the sample grid). of radial distances by numerically integrating previously developed interpolation functions (using the MATLAB integral and integral2 functions, as appropriate) for (a) a disk and (b) circle arc, both centered on the release. For the $1.5 \mathrm{~km}$ extent grid, the distances considered were $50 \mathrm{~m}$ to $1,100 \mathrm{~m}$ at $50 \mathrm{~m}$ increments. For the $30 \mathrm{~km}$ extent grid, the distances considered were $2,000 \mathrm{~m}$ to $20,000 \mathrm{~m}$ at $1,000 \mathrm{~m}$ increments.

Third, we developed a second, linear interpolation function using the griddedlnterpolant function from the distances considered and the normalized time integrated air concentrations calculated in step 2. This function was used for remainder of the analysis.

\footnotetext{
${ }^{41}$ These computational marker particles are a large sample from the possible particles emitted and are used in estimating downwind concentrations along the prescribed contaminant emission amount. These particles do NOT directly represent individual physical aerosols.
} 
medRxiv preprint doi: https://doi.org/10.1101/2020.04.23.20076273; this version posted April 28, 2020. The copyright holder for this preprint (which was not certified by peer review) is the author/funder, who has granted medRxiv a license to display the preprint in perpetuity. It is made available under a CC-BY-NC-ND 4.0 International license .

M Dillon and Particle Model for C Dillon Airborne Disease Transmission

2613 Table E2a. Normalized Time and Space Integrated Particle Air Concentration for a Disc with 2614 the specified distance from the release assuming no airborne loss rate $\left(\lambda_{\text {decay }}=0 \mathrm{~h}^{-1}\right)$.

\begin{tabular}{|c|c|c|c|c|c|c|c|}
\hline $\begin{array}{c}\begin{array}{c}\text { Distance } \\
\text { Downwind }\end{array} \\
(\mathrm{m})\end{array}$ & $\begin{array}{l}\text { Clear, cold } \\
\text { night with } \\
\text { light winds } \\
\left(\mathrm{s} \mathrm{m}^{-1}\right)\end{array}$ & $\begin{array}{c}\text { Clear night } \\
\text { with } \\
\text { gentle } \\
\text { breeze } \\
\left(\mathrm{s} \mathrm{m}^{-1}\right)\end{array}$ & $\begin{array}{c}\text { Overcast } \\
\text { with light } \\
\text { winds } \\
\left(\mathrm{s} \mathrm{m}^{-1}\right)\end{array}$ & $\begin{array}{l}\text { Overcast } \\
\text { with } \\
\text { gentle } \\
\text { winds } \\
\left(\mathrm{s} \mathrm{m}^{-1}\right) \\
\end{array}$ & $\begin{array}{l}\text { Overcast } \\
\text { with } \\
\text { strong } \\
\text { winds } \\
\left(\mathrm{s} \mathrm{m}^{-1}\right) \\
\end{array}$ & $\begin{array}{c}\text { Clear day } \\
\text { with } \\
\text { gentle } \\
\text { winds } \\
\left(\mathrm{s} \mathrm{m}^{-1}\right) \\
\end{array}$ & $\begin{array}{l}\text { Clear, hot } \\
\text { day with } \\
\text { light winds } \\
\left(\mathrm{s} \mathrm{m}^{-1}\right)\end{array}$ \\
\hline 50 & $2.2 \mathrm{E}+01$ & $4.4 \mathrm{E}+00$ & $1.1 \mathrm{E}+01$ & $3.4 \mathrm{E}+00$ & $1.5 \mathrm{E}+00$ & $2.1 \mathrm{E}+00$ & $7.1 \mathrm{E}+00$ \\
\hline 100 & $4.0 \mathrm{E}+01$ & $8.0 E+00$ & $1.6 \mathrm{E}+01$ & $5.6 \mathrm{E}+00$ & $2.5 \mathrm{E}+00$ & $3.0 \mathrm{E}+00$ & $9.5 \mathrm{E}+00$ \\
\hline 150 & $5.6 \mathrm{E}+01$ & $1.1 E+01$ & $1.9 \mathrm{E}+01$ & $7.2 \mathrm{E}+00$ & $3.3 E+00$ & $3.6 \mathrm{E}+00$ & $1.1 \mathrm{E}+01$ \\
\hline 200 & $7.0 \mathrm{E}+01$ & $1.3 E+01$ & $2.2 \mathrm{E}+01$ & $8.4 \mathrm{E}+00$ & $3.8 \mathrm{E}+00$ & $3.9 \mathrm{E}+00$ & $1.2 \mathrm{E}+01$ \\
\hline 250 & $8.3 E+01$ & $1.5 \mathrm{E}+01$ & $2.4 \mathrm{E}+01$ & $9.4 \mathrm{E}+00$ & $4.3 E+00$ & $4.2 E+00$ & $1.3 \mathrm{E}+01$ \\
\hline 300 & $9.4 \mathrm{E}+01$ & $1.7 E+01$ & $2.5 \mathrm{E}+01$ & $1.0 \mathrm{E}+01$ & $4.6 \mathrm{E}+00$ & $4.5 \mathrm{E}+00$ & $1.3 E+01$ \\
\hline 350 & $1.0 \mathrm{E}+02$ & $1.9 E+01$ & $2.6 \mathrm{E}+01$ & $1.1 \mathrm{E}+01$ & $5.0 \mathrm{E}+00$ & $4.6 \mathrm{E}+00$ & $1.4 \mathrm{E}+01$ \\
\hline 400 & $1.1 \mathrm{E}+02$ & $2.0 \mathrm{E}+01$ & $2.8 \mathrm{E}+01$ & $1.2 \mathrm{E}+01$ & $5.3 E+00$ & $4.8 \mathrm{E}+00$ & $1.4 \mathrm{E}+01$ \\
\hline 450 & $1.2 \mathrm{E}+02$ & $2.2 \mathrm{E}+01$ & $2.9 \mathrm{E}+01$ & $1.2 \mathrm{E}+01$ & $5.5 E+00$ & $5.0 \mathrm{E}+00$ & $1.4 \mathrm{E}+01$ \\
\hline 500 & $1.3 \mathrm{E}+02$ & $2.3 \mathrm{E}+01$ & $2.9 \mathrm{E}+01$ & $1.3 \mathrm{E}+01$ & $5.8 \mathrm{E}+00$ & $5.1 \mathrm{E}+00$ & $1.5 \mathrm{E}+01$ \\
\hline 550 & $1.4 \mathrm{E}+02$ & $2.4 \mathrm{E}+01$ & $3.0 E+01$ & $1.3 E+01$ & $6.0 E+00$ & $5.2 \mathrm{E}+00$ & $1.5 E+01$ \\
\hline 600 & $1.4 \mathrm{E}+02$ & $2.5 E+01$ & $3.1 E+01$ & $1.4 \mathrm{E}+01$ & $6.2 \mathrm{E}+00$ & $5.3 \mathrm{E}+00$ & $1.5 \mathrm{E}+01$ \\
\hline 650 & $1.5 \mathrm{E}+02$ & $2.6 \mathrm{E}+01$ & $3.1 E+01$ & $1.4 \mathrm{E}+01$ & $6.4 \mathrm{E}+00$ & $5.4 \mathrm{E}+00$ & $1.5 \mathrm{E}+01$ \\
\hline 700 & $1.5 \mathrm{E}+02$ & $2.7 E+01$ & $3.2 \mathrm{E}+01$ & $1.4 \mathrm{E}+01$ & $6.5 E+00$ & $5.5 \mathrm{E}+00$ & $1.6 \mathrm{E}+01$ \\
\hline 750 & $1.6 \mathrm{E}+02$ & $2.8 \mathrm{E}+01$ & $3.2 \mathrm{E}+01$ & $1.5 E+01$ & $6.7 \mathrm{E}+00$ & $5.5 \mathrm{E}+00$ & $1.6 \mathrm{E}+01$ \\
\hline 800 & $1.6 \mathrm{E}+02$ & $2.9 E+01$ & $3.3 E+01$ & $1.5 \mathrm{E}+01$ & $6.8 \mathrm{E}+00$ & $5.6 \mathrm{E}+00$ & $1.6 \mathrm{E}+01$ \\
\hline 850 & $1.7 \mathrm{E}+02$ & $2.9 E+01$ & $3.3 \mathrm{E}+01$ & $1.5 \mathrm{E}+01$ & $7.0 \mathrm{E}+00$ & $5.7 \mathrm{E}+00$ & $1.6 \mathrm{E}+01$ \\
\hline 900 & $1.7 \mathrm{E}+02$ & $3.0 E+01$ & $3.4 \mathrm{E}+01$ & $1.6 \mathrm{E}+01$ & $7.1 \mathrm{E}+00$ & $5.7 \mathrm{E}+00$ & $1.6 \mathrm{E}+01$ \\
\hline 950 & $1.8 \mathrm{E}+02$ & $3.1 \mathrm{E}+01$ & $3.4 \mathrm{E}+01$ & $1.6 \mathrm{E}+01$ & $7.2 \mathrm{E}+00$ & $5.8 \mathrm{E}+00$ & $1.6 \mathrm{E}+01$ \\
\hline 1,000 & $1.8 \mathrm{E}+02$ & $3.1 E+01$ & $3.4 \mathrm{E}+01$ & $1.6 \mathrm{E}+01$ & $7.4 \mathrm{E}+00$ & $5.8 \mathrm{E}+00$ & $1.6 \mathrm{E}+01$ \\
\hline 1,050 & $1.8 \mathrm{E}+02$ & $3.2 \mathrm{E}+01$ & $3.5 \mathrm{E}+01$ & $1.6 \mathrm{E}+01$ & $7.5 \mathrm{E}+00$ & $5.9 \mathrm{E}+00$ & 1.7E+01 \\
\hline 1,100 & $1.9 E+02$ & $3.3 E+01$ & $3.5 E+01$ & $1.7 \mathrm{E}+01$ & $7.6 \mathrm{E}+00$ & $5.9 \mathrm{E}+00$ & $1.7 \mathrm{E}+01$ \\
\hline 2,000 & $2.3 E+02$ & $3.8 \mathrm{E}+01$ & $3.6 \mathrm{E}+01$ & $1.8 \mathrm{E}+01$ & $8.1 \mathrm{E}+00$ & $6.7 \mathrm{E}+00$ & $1.9 E+01$ \\
\hline 3,000 & $2.6 \mathrm{E}+02$ & $4.2 E+01$ & $3.8 \mathrm{E}+01$ & $1.9 \mathrm{E}+01$ & 8.7E+00 & $7.1 \mathrm{E}+00$ & $1.9 E+01$ \\
\hline 4,000 & $2.8 \mathrm{E}+02$ & $4.6 \mathrm{E}+01$ & $4.0 \mathrm{E}+01$ & $2.0 \mathrm{E}+01$ & $9.2 \mathrm{E}+00$ & $7.3 \mathrm{E}+00$ & $2.0 \mathrm{E}+01$ \\
\hline 5,000 & $3.0 \mathrm{E}+02$ & $4.8 \mathrm{E}+01$ & $4.1 \mathrm{E}+01$ & $2.1 E+01$ & $9.6 \mathrm{E}+00$ & $7.5 \mathrm{E}+00$ & $2.1 \mathrm{E}+01$ \\
\hline 6,000 & $3.1 E+02$ & $5.1 E+01$ & $4.2 E+01$ & $2.2 \mathrm{E}+01$ & $9.9 \mathrm{E}+00$ & 7.7E+00 & $2.1 E+01$ \\
\hline 7,000 & $3.1 E+02$ & $5.3 \mathrm{E}+01$ & $4.3 \mathrm{E}+01$ & $2.2 \mathrm{E}+01$ & $1.0 \mathrm{E}+01$ & $7.9 \mathrm{E}+00$ & $2.2 \mathrm{E}+01$ \\
\hline 8,000 & $3.2 E+02$ & $5.5 E+01$ & $4.4 \mathrm{E}+01$ & $2.3 E+01$ & $1.0 \mathrm{E}+01$ & $8.0 \mathrm{E}+00$ & $2.2 \mathrm{E}+01$ \\
\hline 9,000 & $3.3 E+02$ & $5.7 E+01$ & $4.5 \mathrm{E}+01$ & $2.3 E+01$ & $1.1 \mathrm{E}+01$ & $8.2 \mathrm{E}+00$ & $2.2 \mathrm{E}+01$ \\
\hline 10,000 & $3.3 E+02$ & $5.8 \mathrm{E}+01$ & $4.5 E+01$ & $2.4 \mathrm{E}+01$ & $1.1 \mathrm{E}+01$ & $8.3 E+00$ & $2.3 E+01$ \\
\hline 11,000 & $3.4 \mathrm{E}+02$ & $6.0 \mathrm{E}+01$ & $4.6 \mathrm{E}+01$ & $2.4 \mathrm{E}+01$ & $1.1 \mathrm{E}+01$ & $8.4 \mathrm{E}+00$ & $2.3 E+01$ \\
\hline 12,000 & $3.4 \mathrm{E}+02$ & $6.1 E+01$ & $4.7 E+01$ & $2.4 \mathrm{E}+01$ & $1.1 \mathrm{E}+01$ & $8.5 \mathrm{E}+00$ & $2.4 \mathrm{E}+01$ \\
\hline 13,000 & $3.5 E+02$ & $6.2 \mathrm{E}+01$ & $4.7 \mathrm{E}+01$ & $2.5 E+01$ & $1.2 \mathrm{E}+01$ & 8.7E+00 & $2.4 \mathrm{E}+01$ \\
\hline 14,000 & $3.5 E+02$ & $6.4 \mathrm{E}+01$ & $4.8 \mathrm{E}+01$ & $2.5 E+01$ & $1.2 \mathrm{E}+01$ & $8.8 \mathrm{E}+00$ & $2.4 \mathrm{E}+01$ \\
\hline 15,000 & $3.5 E+02$ & $6.5 \mathrm{E}+01$ & $4.9 E+01$ & $2.6 \mathrm{E}+01$ & $1.2 \mathrm{E}+01$ & $8.9 E+00$ & $2.5 \mathrm{E}+01$ \\
\hline 16,000 & $3.5 \mathrm{E}+02$ & $6.6 \mathrm{E}+01$ & $4.9 \mathrm{E}+01$ & $2.6 \mathrm{E}+01$ & $1.2 \mathrm{E}+01$ & $9.0 \mathrm{E}+00$ & $2.5 \mathrm{E}+01$ \\
\hline 17,000 & $3.6 \mathrm{E}+02$ & $6.7 E+01$ & $5.0 \mathrm{E}+01$ & $2.6 \mathrm{E}+01$ & $1.2 \mathrm{E}+01$ & $9.1 \mathrm{E}+00$ & $2.5 \mathrm{E}+01$ \\
\hline 18,000 & $3.6 \mathrm{E}+02$ & $6.8 \mathrm{E}+01$ & $5.0 \mathrm{E}+01$ & $2.6 \mathrm{E}+01$ & $1.2 \mathrm{E}+01$ & $9.2 \mathrm{E}+00$ & $2.6 \mathrm{E}+01$ \\
\hline 19,000 & $3.6 \mathrm{E}+02$ & $6.9 E+01$ & $5.1 E+01$ & $2.7 \mathrm{E}+01$ & $1.3 E+01$ & $9.3 \mathrm{E}+00$ & $2.6 \mathrm{E}+01$ \\
\hline 20,000 & $3.6 \mathrm{E}+02$ & $7.0 \mathrm{E}+01$ & $5.1 \mathrm{E}+01$ & $2.7 \mathrm{E}+01$ & $1.3 \mathrm{E}+01$ & $9.4 \mathrm{E}+00$ & $2.7 E+01$ \\
\hline
\end{tabular}


medRxiv preprint doi: https://doi.org/10.1101/2020.04.23.20076273; this version posted April 28, 2020. The copyright holder for this preprint (which was not certified by peer review) is the author/funder, who has granted medRxiv a license to display the preprint in perpetuity. It is made available under a CC-BY-NC-ND 4.0 International license .

M Dillon and Particle Model for C Dillon Airborne Disease Transmission

2616 Table E2b. Normalized Time and Space Integrated Particle Air Concentration for a Circle Arc at 2617 the specified distance from the release assuming no airborne loss rate $\left(\lambda_{\text {decay }}=0 \mathrm{~h}^{-1}\right)$.

\begin{tabular}{|c|c|c|c|c|c|c|c|}
\hline $\begin{array}{c}\text { Distance } \\
\text { Downwind } \\
\text { (m) }\end{array}$ & $\begin{array}{c}\text { Clear, cold } \\
\text { night with } \\
\text { light winds } \\
\left(\mathrm{s} \mathrm{m}^{-2}\right)\end{array}$ & $\begin{array}{c}\text { Clear night } \\
\text { with } \\
\text { gentle } \\
\text { breeze } \\
\left(\mathrm{s} \mathrm{m}^{-2}\right)\end{array}$ & $\begin{array}{c}\text { Overcast } \\
\text { with light } \\
\text { winds } \\
\left(s^{-2}\right)\end{array}$ & $\begin{array}{c}\text { Overcast } \\
\text { with } \\
\text { gentle } \\
\text { winds } \\
\left(\mathrm{s} \mathrm{m}^{-2}\right)\end{array}$ & $\begin{array}{l}\text { Overcast } \\
\text { with } \\
\text { strong } \\
\text { winds } \\
\left(\mathrm{s} \mathrm{m}^{-2}\right)\end{array}$ & $\begin{array}{c}\text { Clear day } \\
\text { with } \\
\text { gentle } \\
\text { winds } \\
\left(\mathrm{s} \mathrm{m}^{-2}\right)\end{array}$ & $\begin{array}{c}\text { Clear, hot } \\
\text { day with } \\
\text { light winds } \\
\left(\mathrm{s} \mathrm{m}^{-2}\right)\end{array}$ \\
\hline 50 & $4.0 \mathrm{E}-01$ & $8.0 \mathrm{E}-02$ & $1.4 \mathrm{E}-01$ & $5.4 \mathrm{E}-02$ & $2.4 \mathrm{E}-02$ & $2.4 \mathrm{E}-02$ & $6.9 \mathrm{E}-02$ \\
\hline 100 & $3.4 \mathrm{E}-01$ & $6.4 \mathrm{E}-02$ & $8.1 \mathrm{E}-02$ & $3.6 \mathrm{E}-02$ & $1.6 \mathrm{E}-02$ & 1.3E-02 & $3.5 \mathrm{E}-02$ \\
\hline 150 & $3.0 \mathrm{E}-01$ & $5.3 \mathrm{E}-02$ & $5.6 \mathrm{E}-02$ & $2.8 \mathrm{E}-02$ & $1.2 \mathrm{E}-02$ & 8.9E-03 & $2.3 \mathrm{E}-02$ \\
\hline 200 & 2.6E-01 & $4.5 \mathrm{E}-02$ & $4.2 \mathrm{E}-02$ & $2.2 \mathrm{E}-02$ & $9.9 \mathrm{E}-03$ & $6.5 \mathrm{E}-03$ & $1.6 \mathrm{E}-02$ \\
\hline 250 & $2.3 \mathrm{E}-01$ & $3.9 \mathrm{E}-02$ & $3.4 \mathrm{E}-02$ & $1.8 \mathrm{E}-02$ & 8.3E-03 & $5.1 \mathrm{E}-03$ & $1.3 \mathrm{E}-02$ \\
\hline 300 & $2.1 \mathrm{E}-01$ & $3.4 \mathrm{E}-02$ & $2.8 \mathrm{E}-02$ & $1.6 \mathrm{E}-02$ & 7.1E-03 & $4.2 \mathrm{E}-03$ & $1.0 \mathrm{E}-02$ \\
\hline 350 & $1.9 \mathrm{E}-01$ & $3.1 \mathrm{E}-02$ & $2.3 \mathrm{E}-02$ & $1.4 \mathrm{E}-02$ & $6.2 \mathrm{E}-03$ & $3.5 \mathrm{E}-03$ & 8.5E-03 \\
\hline 400 & 1.7E-01 & $2.8 \mathrm{E}-02$ & $2.0 \mathrm{E}-02$ & $1.2 \mathrm{E}-02$ & $5.5 \mathrm{E}-03$ & 3.1E-03 & $7.2 \mathrm{E}-03$ \\
\hline 450 & $1.6 \mathrm{E}-01$ & $2.5 \mathrm{E}-02$ & $1.8 \mathrm{E}-02$ & $1.1 \mathrm{E}-02$ & $5.0 \mathrm{E}-03$ & 2.7E-03 & $6.2 \mathrm{E}-03$ \\
\hline 500 & $1.5 \mathrm{E}-01$ & $2.3 \mathrm{E}-02$ & $1.6 \mathrm{E}-02$ & $9.8 \mathrm{E}-03$ & $4.5 \mathrm{E}-03$ & $2.3 \mathrm{E}-03$ & 5.5E-03 \\
\hline 550 & $1.4 \mathrm{E}-01$ & $2.2 \mathrm{E}-02$ & $1.4 \mathrm{E}-02$ & $9.0 \mathrm{E}-03$ & $4.1 \mathrm{E}-03$ & $2.1 \mathrm{E}-03$ & 4.9E-03 \\
\hline 600 & $1.3 \mathrm{E}-01$ & $2.0 \mathrm{E}-02$ & $1.3 \mathrm{E}-02$ & $8.3 \mathrm{E}-03$ & $3.8 \mathrm{E}-03$ & $1.9 \mathrm{E}-03$ & 4.4E-03 \\
\hline 650 & $1.2 \mathrm{E}-01$ & $1.9 \mathrm{E}-02$ & $1.2 \mathrm{E}-02$ & 7.7E-03 & $3.5 \mathrm{E}-03$ & 1.7E-03 & 3.9E-03 \\
\hline 700 & $1.1 \mathrm{E}-01$ & $1.8 \mathrm{E}-02$ & $1.1 \mathrm{E}-02$ & 7.3E-03 & $3.3 \mathrm{E}-03$ & 1.6E-03 & 3.6E-03 \\
\hline 750 & $1.0 \mathrm{E}-01$ & 1.7E-02 & $9.8 \mathrm{E}-03$ & $6.8 \mathrm{E}-03$ & $3.1 \mathrm{E}-03$ & $1.4 \mathrm{E}-03$ & 3.3E-03 \\
\hline 800 & $9.6 \mathrm{E}-02$ & $1.6 \mathrm{E}-02$ & $9.0 \mathrm{E}-03$ & $6.4 \mathrm{E}-03$ & $2.9 \mathrm{E}-03$ & $1.3 \mathrm{E}-03$ & $3.1 \mathrm{E}-03$ \\
\hline 850 & $9.0 \mathrm{E}-02$ & $1.5 \mathrm{E}-02$ & $8.3 \mathrm{E}-03$ & $6.0 \mathrm{E}-03$ & $2.8 \mathrm{E}-03$ & $1.3 \mathrm{E}-03$ & 2.9E-03 \\
\hline 900 & $8.4 \mathrm{E}-02$ & $1.4 \mathrm{E}-02$ & 7.7E-03 & $5.8 \mathrm{E}-03$ & $2.6 \mathrm{E}-03$ & $1.2 \mathrm{E}-03$ & 2.7E-03 \\
\hline 950 & $7.8 \mathrm{E}-02$ & $1.4 \mathrm{E}-02$ & $7.2 \mathrm{E}-03$ & $5.5 \mathrm{E}-03$ & $2.5 \mathrm{E}-03$ & $1.1 \mathrm{E}-03$ & $2.5 \mathrm{E}-03$ \\
\hline 1,000 & $7.2 \mathrm{E}-02$ & $1.3 \mathrm{E}-02$ & 6.7E-03 & $5.2 \mathrm{E}-03$ & $2.4 \mathrm{E}-03$ & $1.0 \mathrm{E}-03$ & $2.3 \mathrm{E}-03$ \\
\hline 1,050 & $6.7 \mathrm{E}-02$ & $1.2 \mathrm{E}-02$ & $6.1 \mathrm{E}-03$ & 4.9E-03 & $2.3 \mathrm{E}-03$ & 9.7E-04 & $2.2 \mathrm{E}-03$ \\
\hline 1,100 & $5.9 \mathrm{E}-02$ & $1.2 \mathrm{E}-02$ & $5.5 \mathrm{E}-03$ & 4.7E-03 & $2.2 \mathrm{E}-03$ & $9.0 \mathrm{E}-04$ & $2.0 \mathrm{E}-03$ \\
\hline 2,000 & $3.8 \mathrm{E}-02$ & $5.5 \mathrm{E}-03$ & $2.6 \mathrm{E}-03$ & 1.7E-03 & 7.7E-04 & 4.5E-04 & 1.1E-03 \\
\hline 3,000 & $2.3 \mathrm{E}-02$ & $4.0 \mathrm{E}-03$ & 1.7E-03 & $1.2 \mathrm{E}-03$ & $5.3 \mathrm{E}-04$ & 2.9E-04 & 7.3E-04 \\
\hline 4,000 & $1.6 \mathrm{E}-02$ & $3.1 \mathrm{E}-03$ & $1.3 \mathrm{E}-03$ & 8.9E-04 & $4.2 \mathrm{E}-04$ & 2.3E-04 & 5.9E-04 \\
\hline 5,000 & $1.2 \mathrm{E}-02$ & $2.6 \mathrm{E}-03$ & $1.1 \mathrm{E}-03$ & $7.4 \mathrm{E}-04$ & $3.6 \mathrm{E}-04$ & $1.9 \mathrm{E}-04$ & $5.2 \mathrm{E}-04$ \\
\hline 6,000 & $9.5 \mathrm{E}-03$ & $2.3 \mathrm{E}-03$ & $9.6 \mathrm{E}-04$ & $6.4 \mathrm{E}-04$ & $3.2 \mathrm{E}-04$ & 1.7E-04 & 4.6E-04 \\
\hline 7,000 & $7.8 \mathrm{E}-03$ & $2.0 \mathrm{E}-03$ & $8.6 \mathrm{E}-04$ & $5.6 \mathrm{E}-04$ & $2.8 \mathrm{E}-04$ & $1.5 \mathrm{E}-04$ & 4.4E-04 \\
\hline 8,000 & $6.6 \mathrm{E}-03$ & $1.8 \mathrm{E}-03$ & $8.1 \mathrm{E}-04$ & $5.1 \mathrm{E}-04$ & $2.6 \mathrm{E}-04$ & $1.4 \mathrm{E}-04$ & 4.3E-04 \\
\hline 9,000 & 5.7E-03 & 1.7E-03 & 7.6E-04 & 4.7E-04 & $2.4 \mathrm{E}-04$ & $1.3 \mathrm{E}-04$ & 4.0E-04 \\
\hline 10,000 & $4.9 \mathrm{E}-03$ & $1.5 \mathrm{E}-03$ & $7.0 \mathrm{E}-04$ & $4.3 \mathrm{E}-04$ & $2.3 \mathrm{E}-04$ & $1.3 \mathrm{E}-04$ & $3.8 \mathrm{E}-04$ \\
\hline 11,000 & $4.4 \mathrm{E}-03$ & $1.4 \mathrm{E}-03$ & $6.9 \mathrm{E}-04$ & $4.1 \mathrm{E}-04$ & $2.2 \mathrm{E}-04$ & $1.3 \mathrm{E}-04$ & 3.7E-04 \\
\hline 12,000 & 3.9E-03 & $1.4 \mathrm{E}-03$ & 6.7E-04 & $3.9 \mathrm{E}-04$ & $2.1 \mathrm{E}-04$ & $1.2 \mathrm{E}-04$ & 3.7E-04 \\
\hline 13,000 & $3.6 \mathrm{E}-03$ & $1.3 \mathrm{E}-03$ & $6.3 \mathrm{E}-04$ & $3.7 \mathrm{E}-04$ & 2.0E-04 & $1.2 \mathrm{E}-04$ & 3.7E-04 \\
\hline 14,000 & $3.2 \mathrm{E}-03$ & $1.2 \mathrm{E}-03$ & $6.1 \mathrm{E}-04$ & $3.5 \mathrm{E}-04$ & $1.9 \mathrm{E}-04$ & $1.1 \mathrm{E}-04$ & $3.6 \mathrm{E}-04$ \\
\hline 15,000 & $3.0 \mathrm{E}-03$ & $1.2 \mathrm{E}-03$ & $5.9 \mathrm{E}-04$ & $3.3 \mathrm{E}-04$ & $1.8 \mathrm{E}-04$ & 1.1E-04 & $3.6 \mathrm{E}-04$ \\
\hline 16,000 & 2.7E-03 & $1.1 \mathrm{E}-03$ & 5.7E-04 & $3.2 \mathrm{E}-04$ & 1.7E-04 & $1.1 \mathrm{E}-04$ & 3.6E-04 \\
\hline 17,000 & $2.5 \mathrm{E}-03$ & $1.1 \mathrm{E}-03$ & $5.9 \mathrm{E}-04$ & $3.1 \mathrm{E}-04$ & 1.7E-04 & $1.1 \mathrm{E}-04$ & $3.6 \mathrm{E}-04$ \\
\hline 18,000 & $2.4 \mathrm{E}-03$ & $1.1 \mathrm{E}-03$ & 5.7E-04 & $2.9 \mathrm{E}-04$ & 1.7E-04 & 1.0E-04 & $3.5 \mathrm{E}-04$ \\
\hline 19,000 & $2.2 \mathrm{E}-03$ & $1.0 \mathrm{E}-03$ & $5.4 \mathrm{E}-04$ & $2.8 \mathrm{E}-04$ & $1.6 \mathrm{E}-04$ & $1.1 \mathrm{E}-04$ & $3.5 \mathrm{E}-04$ \\
\hline 20,000 & $2.1 \mathrm{E}-03$ & $9.9 \mathrm{E}-04$ & $5.2 \mathrm{E}-04$ & $2.8 \mathrm{E}-04$ & $1.6 \mathrm{E}-04$ & 1.0E-04 & $3.6 \mathrm{E}-04$ \\
\hline
\end{tabular}


medRxiv preprint doi: https://doi.org/10.1101/2020.04.23.20076273; this version posted April 28, 2020. The copyright holder for this preprint (which was not certified by peer review) is the author/funder, who has granted medRxiv a license to display the preprint in perpetuity. It is made available under a CC-BY-NC-ND 4.0 International license .

M Dillon and Particle Model for C Dillon Airborne Disease Transmission

2619 Table E3a. Normalized Time and Space Integrated Particle Air Concentration for a Disc with 2620 the specified distance from the release assuming airborne loss rate $\left(\lambda_{\text {decay }}=0.1 \mathrm{~h}^{-1}\right)$.

\begin{tabular}{|c|c|c|c|c|c|c|c|}
\hline $\begin{array}{c}\begin{array}{c}\text { Distance } \\
\text { Downwind }\end{array} \\
\text { (m) }\end{array}$ & $\begin{array}{c}\text { Clear, cold } \\
\text { night with } \\
\text { light winds } \\
\left(\mathrm{s} \mathrm{m}^{-1}\right)\end{array}$ & $\begin{array}{c}\text { Clear night } \\
\text { with } \\
\text { gentle } \\
\text { breeze } \\
\left(\mathrm{s} \mathrm{m}^{-1}\right)\end{array}$ & $\begin{array}{c}\text { Overcast } \\
\text { with light } \\
\text { winds } \\
\left(\mathrm{s} \mathrm{m}^{-1}\right)\end{array}$ & $\begin{array}{c}\text { Overcast } \\
\text { with } \\
\text { gentle } \\
\text { winds } \\
\left(\mathrm{s} \mathrm{m}^{-1}\right)\end{array}$ & $\begin{array}{c}\text { Overcast } \\
\text { with } \\
\text { strong } \\
\text { winds } \\
\left(\mathbf{s ~ m}^{-1}\right)\end{array}$ & $\begin{array}{c}\text { Clear day } \\
\text { with } \\
\text { gentle } \\
\text { winds } \\
\left(\mathrm{s} \mathrm{m}^{-1}\right)\end{array}$ & $\begin{array}{c}\text { Clear, hot } \\
\text { day with } \\
\text { light winds } \\
\left(\mathrm{s} \mathrm{m}^{-1}\right)\end{array}$ \\
\hline 50 & $2.2 \mathrm{E}+01$ & $4.4 \mathrm{E}+00$ & $1.1 \mathrm{E}+01$ & $3.4 \mathrm{E}+00$ & $1.5 \mathrm{E}+00$ & $2.1 \mathrm{E}+00$ & $7.1 \mathrm{E}+00$ \\
\hline 100 & $4.0 \mathrm{E}+01$ & $8.0 \mathrm{E}+00$ & $1.6 \mathrm{E}+01$ & $5.6 \mathrm{E}+00$ & $2.5 \mathrm{E}+00$ & $3.0 \mathrm{E}+00$ & $9.5 \mathrm{E}+00$ \\
\hline 150 & $5.6 \mathrm{E}+01$ & $1.1 \mathrm{E}+01$ & $1.9 \mathrm{E}+01$ & $7.2 \mathrm{E}+00$ & $3.3 \mathrm{E}+00$ & $3.6 \mathrm{E}+00$ & $1.1 \mathrm{E}+01$ \\
\hline 200 & $7.0 \mathrm{E}+01$ & $1.3 \mathrm{E}+01$ & $2.2 \mathrm{E}+01$ & $8.4 \mathrm{E}+00$ & $3.8 \mathrm{E}+00$ & $3.9 \mathrm{E}+00$ & $1.2 \mathrm{E}+01$ \\
\hline 250 & $8.2 \mathrm{E}+01$ & $1.5 \mathrm{E}+01$ & $2.4 \mathrm{E}+01$ & $9.4 \mathrm{E}+00$ & $4.3 \mathrm{E}+00$ & $4.2 \mathrm{E}+00$ & $1.3 \mathrm{E}+01$ \\
\hline 300 & $9.3 \mathrm{E}+01$ & 1.7E+01 & $2.5 \mathrm{E}+01$ & $1.0 \mathrm{E}+01$ & $4.6 \mathrm{E}+00$ & $4.5 E+00$ & $1.3 \mathrm{E}+01$ \\
\hline 350 & $1.0 \mathrm{E}+02$ & $1.9 \mathrm{E}+01$ & $2.6 \mathrm{E}+01$ & $1.1 \mathrm{E}+01$ & $5.0 \mathrm{E}+00$ & $4.6 \mathrm{E}+00$ & $1.4 \mathrm{E}+01$ \\
\hline 400 & $1.1 \mathrm{E}+02$ & $2.0 \mathrm{E}+01$ & $2.7 \mathrm{E}+01$ & $1.2 \mathrm{E}+01$ & $5.3 E+00$ & $4.8 \mathrm{E}+00$ & $1.4 \mathrm{E}+01$ \\
\hline 450 & $1.2 \mathrm{E}+02$ & $2.2 \mathrm{E}+01$ & $2.8 \mathrm{E}+01$ & $1.2 \mathrm{E}+01$ & $5.5 \mathrm{E}+00$ & $5.0 \mathrm{E}+00$ & $1.4 \mathrm{E}+01$ \\
\hline 500 & $1.3 \mathrm{E}+02$ & $2.3 \mathrm{E}+01$ & $2.9 \mathrm{E}+01$ & $1.3 \mathrm{E}+01$ & $5.8 \mathrm{E}+00$ & $5.1 \mathrm{E}+00$ & $1.5 \mathrm{E}+01$ \\
\hline 550 & $1.3 \mathrm{E}+02$ & $2.4 \mathrm{E}+01$ & $3.0 \mathrm{E}+01$ & $1.3 \mathrm{E}+01$ & $6.0 \mathrm{E}+00$ & $5.2 \mathrm{E}+00$ & $1.5 \mathrm{E}+01$ \\
\hline 600 & $1.4 \mathrm{E}+02$ & $2.5 \mathrm{E}+01$ & $3.1 \mathrm{E}+01$ & $1.4 \mathrm{E}+01$ & $6.2 \mathrm{E}+00$ & $5.3 E+00$ & $1.5 \mathrm{E}+01$ \\
\hline 650 & $1.5 \mathrm{E}+02$ & $2.6 \mathrm{E}+01$ & $3.1 \mathrm{E}+01$ & $1.4 \mathrm{E}+01$ & $6.3 E+00$ & $5.4 \mathrm{E}+00$ & $1.5 \mathrm{E}+01$ \\
\hline 700 & $1.5 \mathrm{E}+02$ & $2.7 \mathrm{E}+01$ & $3.2 \mathrm{E}+01$ & $1.4 \mathrm{E}+01$ & $6.5 E+00$ & $5.5 E+00$ & $1.5 \mathrm{E}+01$ \\
\hline 750 & $1.6 \mathrm{E}+02$ & $2.8 \mathrm{E}+01$ & $3.2 \mathrm{E}+01$ & $1.5 \mathrm{E}+01$ & $6.7 \mathrm{E}+00$ & $5.5 \mathrm{E}+00$ & $1.6 \mathrm{E}+01$ \\
\hline 800 & $1.6 \mathrm{E}+02$ & $2.8 \mathrm{E}+01$ & $3.3 \mathrm{E}+01$ & $1.5 \mathrm{E}+01$ & $6.8 \mathrm{E}+00$ & $5.6 \mathrm{E}+00$ & $1.6 \mathrm{E}+01$ \\
\hline 850 & $1.7 \mathrm{E}+02$ & $2.9 \mathrm{E}+01$ & $3.3 \mathrm{E}+01$ & $1.5 \mathrm{E}+01$ & $7.0 \mathrm{E}+00$ & $5.7 \mathrm{E}+00$ & $1.6 \mathrm{E}+01$ \\
\hline 900 & $1.7 \mathrm{E}+02$ & $3.0 \mathrm{E}+01$ & $3.3 \mathrm{E}+01$ & $1.6 \mathrm{E}+01$ & $7.1 \mathrm{E}+00$ & $5.7 \mathrm{E}+00$ & $1.6 \mathrm{E}+01$ \\
\hline 950 & 1.7E+02 & $3.1 \mathrm{E}+01$ & $3.4 \mathrm{E}+01$ & $1.6 \mathrm{E}+01$ & $7.2 \mathrm{E}+00$ & $5.8 \mathrm{E}+00$ & $1.6 \mathrm{E}+01$ \\
\hline 1,000 & $1.8 \mathrm{E}+02$ & $3.1 \mathrm{E}+01$ & $3.4 \mathrm{E}+01$ & $1.6 \mathrm{E}+01$ & $7.4 \mathrm{E}+00$ & $5.8 \mathrm{E}+00$ & $1.6 \mathrm{E}+01$ \\
\hline 1,050 & $1.8 \mathrm{E}+02$ & $3.2 \mathrm{E}+01$ & $3.5 \mathrm{E}+01$ & $1.6 \mathrm{E}+01$ & $7.5 \mathrm{E}+00$ & $5.9 \mathrm{E}+00$ & $1.6 \mathrm{E}+01$ \\
\hline 1,100 & $1.8 \mathrm{E}+02$ & $3.2 \mathrm{E}+01$ & $3.5 \mathrm{E}+01$ & $1.7 \mathrm{E}+01$ & $7.6 \mathrm{E}+00$ & $5.9 \mathrm{E}+00$ & $1.7 \mathrm{E}+01$ \\
\hline 2,000 & $2.3 \mathrm{E}+02$ & $3.7 \mathrm{E}+01$ & $3.6 \mathrm{E}+01$ & $1.8 \mathrm{E}+01$ & $8.1 E+00$ & $6.7 E+00$ & $1.8 \mathrm{E}+01$ \\
\hline 3,000 & $2.5 \mathrm{E}+02$ & $4.2 \mathrm{E}+01$ & $3.8 \mathrm{E}+01$ & $1.9 \mathrm{E}+01$ & $8.7 E+00$ & $7.1 \mathrm{E}+00$ & $1.9 \mathrm{E}+01$ \\
\hline 4,000 & $2.7 \mathrm{E}+02$ & $4.5 \mathrm{E}+01$ & $3.9 \mathrm{E}+01$ & $2.0 \mathrm{E}+01$ & $9.1 \mathrm{E}+00$ & $7.3 \mathrm{E}+00$ & $2.0 \mathrm{E}+01$ \\
\hline 5,000 & $2.8 \mathrm{E}+02$ & $4.8 \mathrm{E}+01$ & $4.0 \mathrm{E}+01$ & $2.1 \mathrm{E}+01$ & $9.5 \mathrm{E}+00$ & $7.5 \mathrm{E}+00$ & $2.0 \mathrm{E}+01$ \\
\hline 6,000 & $2.9 \mathrm{E}+02$ & $5.0 \mathrm{E}+01$ & $4.1 \mathrm{E}+01$ & $2.1 \mathrm{E}+01$ & $9.9 \mathrm{E}+00$ & $7.7 E+00$ & $2.1 \mathrm{E}+01$ \\
\hline 7,000 & $3.0 \mathrm{E}+02$ & $5.2 \mathrm{E}+01$ & $4.2 \mathrm{E}+01$ & $2.2 \mathrm{E}+01$ & $1.0 \mathrm{E}+01$ & $7.8 \mathrm{E}+00$ & $2.1 \mathrm{E}+01$ \\
\hline 8,000 & $3.0 \mathrm{E}+02$ & $5.4 \mathrm{E}+01$ & $4.3 \mathrm{E}+01$ & $2.2 \mathrm{E}+01$ & $1.0 \mathrm{E}+01$ & $8.0 \mathrm{E}+00$ & $2.2 \mathrm{E}+01$ \\
\hline 9,000 & $3.1 \mathrm{E}+02$ & $5.6 \mathrm{E}+01$ & $4.3 \mathrm{E}+01$ & $2.3 \mathrm{E}+01$ & $1.1 \mathrm{E}+01$ & $8.1 \mathrm{E}+00$ & $2.2 \mathrm{E}+01$ \\
\hline 10,000 & $3.1 \mathrm{E}+02$ & $5.7 \mathrm{E}+01$ & $4.4 \mathrm{E}+01$ & $2.3 \mathrm{E}+01$ & $1.1 \mathrm{E}+01$ & $8.2 \mathrm{E}+00$ & $2.2 \mathrm{E}+01$ \\
\hline 11,000 & $3.1 \mathrm{E}+02$ & $5.9 \mathrm{E}+01$ & $4.4 \mathrm{E}+01$ & $2.4 \mathrm{E}+01$ & $1.1 \mathrm{E}+01$ & $8.4 \mathrm{E}+00$ & $2.3 \mathrm{E}+01$ \\
\hline 12,000 & $3.2 \mathrm{E}+02$ & $6.0 \mathrm{E}+01$ & $4.5 E+01$ & $2.4 \mathrm{E}+01$ & $1.1 \mathrm{E}+01$ & $8.5 E+00$ & $2.3 \mathrm{E}+01$ \\
\hline 13,000 & $3.2 \mathrm{E}+02$ & $6.1 \mathrm{E}+01$ & $4.5 \mathrm{E}+01$ & $2.4 \mathrm{E}+01$ & $1.1 \mathrm{E}+01$ & $8.6 \mathrm{E}+00$ & $2.3 \mathrm{E}+01$ \\
\hline 14,000 & $3.2 \mathrm{E}+02$ & $6.2 \mathrm{E}+01$ & $4.6 \mathrm{E}+01$ & $2.5 \mathrm{E}+01$ & $1.2 \mathrm{E}+01$ & $8.7 E+00$ & $2.3 E+01$ \\
\hline 15,000 & $3.2 \mathrm{E}+02$ & $6.4 \mathrm{E}+01$ & $4.6 \mathrm{E}+01$ & $2.5 \mathrm{E}+01$ & $1.2 \mathrm{E}+01$ & $8.8 \mathrm{E}+00$ & $2.4 \mathrm{E}+01$ \\
\hline 16,000 & $3.3 \mathrm{E}+02$ & $6.5 \mathrm{E}+01$ & $4.7 \mathrm{E}+01$ & $2.5 \mathrm{E}+01$ & $1.2 \mathrm{E}+01$ & $8.9 \mathrm{E}+00$ & $2.4 \mathrm{E}+01$ \\
\hline 17,000 & $3.3 \mathrm{E}+02$ & $6.6 \mathrm{E}+01$ & 4.7E+01 & $2.6 \mathrm{E}+01$ & $1.2 \mathrm{E}+01$ & $9.0 \mathrm{E}+00$ & $2.4 \mathrm{E}+01$ \\
\hline 18,000 & $3.3 \mathrm{E}+02$ & $6.7 \mathrm{E}+01$ & $4.8 \mathrm{E}+01$ & $2.6 \mathrm{E}+01$ & $1.2 \mathrm{E}+01$ & $9.1 \mathrm{E}+00$ & $2.4 \mathrm{E}+01$ \\
\hline 19,000 & $3.3 \mathrm{E}+02$ & $6.8 \mathrm{E}+01$ & $4.8 \mathrm{E}+01$ & $2.6 \mathrm{E}+01$ & $1.3 \mathrm{E}+01$ & $9.2 \mathrm{E}+00$ & $2.5 \mathrm{E}+01$ \\
\hline 20,000 & $3.3 E+02$ & $6.8 \mathrm{E}+01$ & $4.8 \mathrm{E}+01$ & 2.7E+01 & $1.3 \mathrm{E}+01$ & $9.3 \mathrm{E}+00$ & $2.5 \mathrm{E}+01$ \\
\hline
\end{tabular}


medRxiv preprint doi: https://doi.org/10.1101/2020.04.23.20076273; this version posted April 28, 2020. The copyright holder for this preprint (which was not certified by peer review) is the author/funder, who has granted medRxiv a license to display the preprint in perpetuity. It is made available under a CC-BY-NC-ND 4.0 International license .

M Dillon and Particle Model for C Dillon Airborne Disease Transmission

2622 Table E3b. Normalized Time and Space Integrated Particle Air Concentration for a Circle Arc at 2623 the specified distance from the release assuming airborne loss rate $\left(\lambda_{\text {decay }}=0.1 \mathrm{~h}^{-1}\right)$.

\begin{tabular}{|c|c|c|c|c|c|c|c|}
\hline $\begin{array}{c}\text { Distance } \\
\text { Downwind } \\
\text { (m) }\end{array}$ & $\begin{array}{c}\text { Clear, cold } \\
\text { night with } \\
\text { light winds } \\
\left(\mathrm{s} \mathrm{m}^{-2}\right)\end{array}$ & $\begin{array}{c}\text { Clear night } \\
\text { with } \\
\text { gentle } \\
\text { breeze } \\
\left(\mathrm{s} \mathrm{m}^{-2}\right)\end{array}$ & $\begin{array}{c}\text { Overcast } \\
\text { with light } \\
\text { winds } \\
\left(s^{-2}\right)\end{array}$ & $\begin{array}{c}\text { Overcast } \\
\text { with } \\
\text { gentle } \\
\text { winds } \\
\left(\mathrm{s} \mathrm{m}^{-2}\right)\end{array}$ & $\begin{array}{l}\text { Overcast } \\
\text { with } \\
\text { strong } \\
\text { winds } \\
\left(\mathrm{s} \mathrm{m}^{-2}\right)\end{array}$ & $\begin{array}{c}\text { Clear day } \\
\text { with } \\
\text { gentle } \\
\text { winds } \\
\left(\mathrm{s} \mathrm{m}^{-2}\right)\end{array}$ & $\begin{array}{c}\text { Clear, hot } \\
\text { day with } \\
\text { light winds } \\
\left(\mathrm{s} \mathrm{m}^{-2}\right)\end{array}$ \\
\hline 50 & $4.0 \mathrm{E}-01$ & $8.0 \mathrm{E}-02$ & $1.3 \mathrm{E}-01$ & $5.4 \mathrm{E}-02$ & $2.4 \mathrm{E}-02$ & $2.4 \mathrm{E}-02$ & $6.9 \mathrm{E}-02$ \\
\hline 100 & $3.4 \mathrm{E}-01$ & $6.4 \mathrm{E}-02$ & $8.0 \mathrm{E}-02$ & $3.6 \mathrm{E}-02$ & $1.6 \mathrm{E}-02$ & 1.3E-02 & $3.5 \mathrm{E}-02$ \\
\hline 150 & $3.0 \mathrm{E}-01$ & $5.3 \mathrm{E}-02$ & $5.6 \mathrm{E}-02$ & $2.8 \mathrm{E}-02$ & $1.2 \mathrm{E}-02$ & 8.9E-03 & $2.3 \mathrm{E}-02$ \\
\hline 200 & 2.6E-01 & 4.4E-02 & $4.2 \mathrm{E}-02$ & $2.2 \mathrm{E}-02$ & $9.9 \mathrm{E}-03$ & $6.5 \mathrm{E}-03$ & $1.6 \mathrm{E}-02$ \\
\hline 250 & $2.3 \mathrm{E}-01$ & $3.9 \mathrm{E}-02$ & $3.3 \mathrm{E}-02$ & $1.8 \mathrm{E}-02$ & $8.2 \mathrm{E}-03$ & $5.1 \mathrm{E}-03$ & $1.3 \mathrm{E}-02$ \\
\hline 300 & 2.1E-01 & $3.4 \mathrm{E}-02$ & $2.8 \mathrm{E}-02$ & 1.6E-02 & 7.1E-03 & $4.2 \mathrm{E}-03$ & 1.0E-02 \\
\hline 350 & $1.9 \mathrm{E}-01$ & $3.1 \mathrm{E}-02$ & $2.3 \mathrm{E}-02$ & $1.4 \mathrm{E}-02$ & $6.2 \mathrm{E}-03$ & $3.5 \mathrm{E}-03$ & 8.4E-03 \\
\hline 400 & 1.7E-01 & $2.8 \mathrm{E}-02$ & $2.0 \mathrm{E}-02$ & $1.2 \mathrm{E}-02$ & $5.5 \mathrm{E}-03$ & 3.1E-03 & 7.1E-03 \\
\hline 450 & $1.5 \mathrm{E}-01$ & $2.5 \mathrm{E}-02$ & 1.7E-02 & $1.1 \mathrm{E}-02$ & $4.9 \mathrm{E}-03$ & 2.7E-03 & 6.1E-03 \\
\hline 500 & $1.4 \mathrm{E}-01$ & $2.3 \mathrm{E}-02$ & $1.5 \mathrm{E}-02$ & $9.8 \mathrm{E}-03$ & $4.5 \mathrm{E}-03$ & $2.3 \mathrm{E}-03$ & $5.4 \mathrm{E}-03$ \\
\hline 550 & $1.3 \mathrm{E}-01$ & $2.1 \mathrm{E}-02$ & $1.4 \mathrm{E}-02$ & $9.0 \mathrm{E}-03$ & $4.1 \mathrm{E}-03$ & $2.1 \mathrm{E}-03$ & $4.8 \mathrm{E}-03$ \\
\hline 600 & $1.2 \mathrm{E}-01$ & $2.0 \mathrm{E}-02$ & $1.3 \mathrm{E}-02$ & $8.3 \mathrm{E}-03$ & $3.8 \mathrm{E}-03$ & $1.9 \mathrm{E}-03$ & 4.3E-03 \\
\hline 650 & $1.1 \mathrm{E}-01$ & $1.9 \mathrm{E}-02$ & $1.1 \mathrm{E}-02$ & 7.7E-03 & $3.5 \mathrm{E}-03$ & 1.7E-03 & $3.8 \mathrm{E}-03$ \\
\hline 700 & $1.1 \mathrm{E}-01$ & 1.7E-02 & $1.0 \mathrm{E}-02$ & $7.2 \mathrm{E}-03$ & $3.3 \mathrm{E}-03$ & 1.6E-03 & 3.5E-03 \\
\hline 750 & $1.0 \mathrm{E}-01$ & 1.7E-02 & $9.6 \mathrm{E}-03$ & 6.7E-03 & $3.1 \mathrm{E}-03$ & $1.4 \mathrm{E}-03$ & 3.3E-03 \\
\hline 800 & $9.3 \mathrm{E}-02$ & $1.6 \mathrm{E}-02$ & $8.8 \mathrm{E}-03$ & $6.3 \mathrm{E}-03$ & $2.9 \mathrm{E}-03$ & $1.3 \mathrm{E}-03$ & 3.0E-03 \\
\hline 850 & $8.6 \mathrm{E}-02$ & $1.5 \mathrm{E}-02$ & $8.1 \mathrm{E}-03$ & $6.0 \mathrm{E}-03$ & $2.8 \mathrm{E}-03$ & $1.2 \mathrm{E}-03$ & $2.8 \mathrm{E}-03$ \\
\hline 900 & $8.0 \mathrm{E}-02$ & $1.4 \mathrm{E}-02$ & $7.5 \mathrm{E}-03$ & 5.7E-03 & $2.6 \mathrm{E}-03$ & $1.2 \mathrm{E}-03$ & $2.6 \mathrm{E}-03$ \\
\hline 950 & $7.5 \mathrm{E}-02$ & $1.3 \mathrm{E}-02$ & 7.0E-03 & $5.4 \mathrm{E}-03$ & $2.5 \mathrm{E}-03$ & $1.1 \mathrm{E}-03$ & $2.4 \mathrm{E}-03$ \\
\hline 1,000 & $6.9 \mathrm{E}-02$ & $1.3 \mathrm{E}-02$ & $6.5 \mathrm{E}-03$ & $5.1 \mathrm{E}-03$ & $2.4 \mathrm{E}-03$ & $1.0 \mathrm{E}-03$ & $2.3 \mathrm{E}-03$ \\
\hline 1,050 & $6.3 \mathrm{E}-02$ & $1.2 \mathrm{E}-02$ & $6.0 \mathrm{E}-03$ & $4.9 \mathrm{E}-03$ & $2.3 \mathrm{E}-03$ & 9.7E-04 & $2.1 \mathrm{E}-03$ \\
\hline 1,100 & $5.6 \mathrm{E}-02$ & $1.2 \mathrm{E}-02$ & $5.3 \mathrm{E}-03$ & 4.6E-03 & $2.1 \mathrm{E}-03$ & 8.9E-04 & $1.9 \mathrm{E}-03$ \\
\hline 2,000 & $3.5 \mathrm{E}-02$ & $5.4 \mathrm{E}-03$ & $2.4 \mathrm{E}-03$ & $1.6 \mathrm{E}-03$ & 7.6E-04 & 4.4E-04 & 1.0E-03 \\
\hline 3,000 & $2.1 \mathrm{E}-02$ & $3.9 \mathrm{E}-03$ & $1.6 \mathrm{E}-03$ & 1.1E-03 & $5.3 \mathrm{E}-04$ & 2.9E-04 & $6.8 \mathrm{E}-04$ \\
\hline 4,000 & $1.4 \mathrm{E}-02$ & $3.1 \mathrm{E}-03$ & $1.2 \mathrm{E}-03$ & 8.7E-04 & $4.2 \mathrm{E}-04$ & $2.2 \mathrm{E}-04$ & 5.3E-04 \\
\hline 5,000 & $1.0 \mathrm{E}-02$ & $2.5 \mathrm{E}-03$ & $9.6 \mathrm{E}-04$ & $7.2 \mathrm{E}-04$ & $3.5 \mathrm{E}-04$ & $1.9 \mathrm{E}-04$ & 4.6E-04 \\
\hline 6,000 & $7.8 \mathrm{E}-03$ & $2.2 \mathrm{E}-03$ & $8.3 \mathrm{E}-04$ & $6.2 \mathrm{E}-04$ & $3.1 \mathrm{E}-04$ & $1.6 \mathrm{E}-04$ & 4.0E-04 \\
\hline 7,000 & $6.2 \mathrm{E}-03$ & $1.9 \mathrm{E}-03$ & 7.3E-04 & $5.4 \mathrm{E}-04$ & $2.8 \mathrm{E}-04$ & $1.5 \mathrm{E}-04$ & 3.7E-04 \\
\hline 8,000 & $5.2 \mathrm{E}-03$ & 1.7E-03 & 6.7E-04 & $4.8 \mathrm{E}-04$ & $2.6 \mathrm{E}-04$ & $1.3 \mathrm{E}-04$ & 3.6E-04 \\
\hline 9,000 & 4.3E-03 & $1.6 \mathrm{E}-03$ & $6.2 \mathrm{E}-04$ & $4.5 \mathrm{E}-04$ & $2.4 \mathrm{E}-04$ & $1.3 \mathrm{E}-04$ & 3.3E-04 \\
\hline 10,000 & 3.7E-03 & $1.5 \mathrm{E}-03$ & $5.6 \mathrm{E}-04$ & 4.1E-04 & $2.2 \mathrm{E}-04$ & $1.2 \mathrm{E}-04$ & 3.0E-04 \\
\hline 11,000 & $3.2 \mathrm{E}-03$ & $1.4 \mathrm{E}-03$ & $5.4 \mathrm{E}-04$ & $3.8 \mathrm{E}-04$ & $2.1 \mathrm{E}-04$ & $1.2 \mathrm{E}-04$ & 2.9E-04 \\
\hline 12,000 & $2.8 \mathrm{E}-03$ & $1.3 \mathrm{E}-03$ & $5.1 \mathrm{E}-04$ & 3.7E-04 & $2.0 \mathrm{E}-04$ & 1.1E-04 & $2.8 \mathrm{E}-04$ \\
\hline 13,000 & $2.5 \mathrm{E}-03$ & $1.2 \mathrm{E}-03$ & 4.7E-04 & $3.5 \mathrm{E}-04$ & $1.9 \mathrm{E}-04$ & 1.1E-04 & $2.8 \mathrm{E}-04$ \\
\hline 14,000 & $2.2 \mathrm{E}-03$ & $1.1 \mathrm{E}-03$ & 4.4E-04 & $3.3 \mathrm{E}-04$ & $1.9 \mathrm{E}-04$ & $1.1 \mathrm{E}-04$ & $2.6 \mathrm{E}-04$ \\
\hline 15,000 & 2.0E-03 & $1.1 \mathrm{E}-03$ & $4.2 \mathrm{E}-04$ & $3.1 \mathrm{E}-04$ & $1.8 \mathrm{E}-04$ & 1.0E-04 & $2.5 \mathrm{E}-04$ \\
\hline 16,000 & $1.8 \mathrm{E}-03$ & $1.0 \mathrm{E}-03$ & $4.0 \mathrm{E}-04$ & $2.9 \mathrm{E}-04$ & 1.7E-04 & $9.9 \mathrm{E}-05$ & $2.5 \mathrm{E}-04$ \\
\hline 17,000 & $1.7 \mathrm{E}-03$ & $1.0 \mathrm{E}-03$ & 4.0E-04 & $2.8 \mathrm{E}-04$ & 1.7E-04 & 1.0E-04 & $2.4 \mathrm{E}-04$ \\
\hline 18,000 & $1.5 \mathrm{E}-03$ & $9.6 \mathrm{E}-04$ & $3.8 \mathrm{E}-04$ & 2.7E-04 & $1.6 \mathrm{E}-04$ & $9.4 \mathrm{E}-05$ & $2.3 \mathrm{E}-04$ \\
\hline 19,000 & $1.4 \mathrm{E}-03$ & $9.2 \mathrm{E}-04$ & $3.5 \mathrm{E}-04$ & $2.5 \mathrm{E}-04$ & $1.6 \mathrm{E}-04$ & $9.9 \mathrm{E}-05$ & $2.3 \mathrm{E}-04$ \\
\hline 20,000 & $1.3 \mathrm{E}-03$ & $8.9 \mathrm{E}-04$ & $3.3 \mathrm{E}-04$ & $2.5 \mathrm{E}-04$ & $1.5 \mathrm{E}-04$ & $9.4 \mathrm{E}-05$ & $2.3 \mathrm{E}-04$ \\
\hline
\end{tabular}


medRxiv preprint doi: https://doi.org/10.1101/2020.04.23.20076273; this version posted April 28, 2020. The copyright holder for this preprint (which was not certified by peer review) is the author/funder, who has granted medRxiv a license to display the preprint in perpetuity. It is made available under a CC-BY-NC-ND 4.0 International license .

M Dillon and Particle Model for C Dillon Airborne Disease Transmission

2625 Table E4a. Normalized Time and Space Integrated Particle Air Concentration for a Disc with 2626 the specified distance from the release assuming airborne loss rate $\left(\lambda_{\text {decay }}=1 \mathrm{~h}^{-1}\right)$.

\begin{tabular}{|c|c|c|c|c|c|c|c|}
\hline $\begin{array}{c}\begin{array}{c}\text { Distance } \\
\text { Downwind }\end{array} \\
(\mathrm{m})\end{array}$ & $\begin{array}{c}\text { Clear, cold } \\
\text { night with } \\
\text { light winds } \\
\left(\mathrm{s} \mathrm{m}^{-1}\right)\end{array}$ & $\begin{array}{c}\text { Clear night } \\
\text { with } \\
\text { gentle } \\
\text { breeze } \\
\left(\mathrm{s} \mathrm{m}^{-1}\right)\end{array}$ & $\begin{array}{c}\text { Overcast } \\
\text { with light } \\
\text { winds } \\
\left(s^{-1}\right)\end{array}$ & $\begin{array}{l}\text { Overcast } \\
\text { with } \\
\text { gentle } \\
\text { winds } \\
\left(\mathbf{s ~ m}^{-1}\right) \\
\end{array}$ & $\begin{array}{l}\text { Overcast } \\
\text { with } \\
\text { strong } \\
\text { winds } \\
\left(\mathrm{s} \mathrm{m}^{-1}\right) \\
\end{array}$ & $\begin{array}{l}\text { Clear day } \\
\text { with } \\
\text { gentle } \\
\text { winds } \\
\left(\mathbf{s ~ m}^{-1}\right) \\
\end{array}$ & $\begin{array}{c}\text { Clear, hot } \\
\text { day with } \\
\text { light winds } \\
\left(\mathrm{s} \mathrm{m}^{-1}\right)\end{array}$ \\
\hline 50 & $2.1 \mathrm{E}+01$ & $4.4 \mathrm{E}+00$ & $1.1 \mathrm{E}+01$ & $3.4 \mathrm{E}+00$ & $1.5 \mathrm{E}+00$ & $2.1 \mathrm{E}+00$ & $7.0 \mathrm{E}+00$ \\
\hline 100 & $3.9 \mathrm{E}+01$ & $7.9 \mathrm{E}+00$ & $1.6 \mathrm{E}+01$ & $5.6 \mathrm{E}+00$ & $2.5 \mathrm{E}+00$ & $3.0 \mathrm{E}+00$ & $9.4 \mathrm{E}+00$ \\
\hline 150 & $5.3 \mathrm{E}+01$ & $1.1 \mathrm{E}+01$ & $1.9 \mathrm{E}+01$ & $7.2 \mathrm{E}+00$ & $3.2 \mathrm{E}+00$ & $3.5 \mathrm{E}+00$ & $1.1 \mathrm{E}+01$ \\
\hline 200 & $6.6 \mathrm{E}+01$ & $1.3 \mathrm{E}+01$ & $2.1 \mathrm{E}+01$ & $8.4 \mathrm{E}+00$ & $3.8 \mathrm{E}+00$ & $3.9 \mathrm{E}+00$ & $1.2 \mathrm{E}+01$ \\
\hline 250 & $7.6 \mathrm{E}+01$ & $1.5 \mathrm{E}+01$ & $2.3 \mathrm{E}+01$ & $9.3 \mathrm{E}+00$ & $4.2 \mathrm{E}+00$ & $4.2 \mathrm{E}+00$ & $1.2 \mathrm{E}+01$ \\
\hline 300 & $8.6 \mathrm{E}+01$ & 1.7E+01 & $2.4 \mathrm{E}+01$ & $1.0 \mathrm{E}+01$ & $4.6 \mathrm{E}+00$ & $4.4 \mathrm{E}+00$ & $1.3 \mathrm{E}+01$ \\
\hline 350 & $9.4 \mathrm{E}+01$ & $1.9 \mathrm{E}+01$ & $2.5 \mathrm{E}+01$ & $1.1 \mathrm{E}+01$ & $4.9 \mathrm{E}+00$ & $4.6 \mathrm{E}+00$ & $1.3 \mathrm{E}+01$ \\
\hline 400 & $1.0 \mathrm{E}+02$ & $2.0 \mathrm{E}+01$ & $2.6 \mathrm{E}+01$ & $1.1 \mathrm{E}+01$ & $5.2 \mathrm{E}+00$ & $4.8 \mathrm{E}+00$ & $1.4 \mathrm{E}+01$ \\
\hline 450 & $1.1 \mathrm{E}+02$ & $2.1 \mathrm{E}+01$ & 2.7E+01 & $1.2 \mathrm{E}+01$ & $5.5 \mathrm{E}+00$ & $4.9 \mathrm{E}+00$ & $1.4 \mathrm{E}+01$ \\
\hline 500 & $1.1 \mathrm{E}+02$ & $2.2 \mathrm{E}+01$ & $2.8 \mathrm{E}+01$ & $1.3 \mathrm{E}+01$ & $5.7 \mathrm{E}+00$ & $5.0 \mathrm{E}+00$ & $1.4 \mathrm{E}+01$ \\
\hline 550 & $1.2 \mathrm{E}+02$ & $2.3 \mathrm{E}+01$ & $2.9 \mathrm{E}+01$ & $1.3 \mathrm{E}+01$ & $5.9 \mathrm{E}+00$ & $5.1 \mathrm{E}+00$ & $1.4 \mathrm{E}+01$ \\
\hline 600 & $1.2 \mathrm{E}+02$ & $2.4 \mathrm{E}+01$ & $2.9 E+01$ & $1.3 \mathrm{E}+01$ & $6.1 \mathrm{E}+00$ & $5.2 \mathrm{E}+00$ & $1.5 \mathrm{E}+01$ \\
\hline 650 & $1.3 \mathrm{E}+02$ & $2.5 \mathrm{E}+01$ & $3.0 \mathrm{E}+01$ & $1.4 \mathrm{E}+01$ & $6.3 \mathrm{E}+00$ & $5.3 \mathrm{E}+00$ & $1.5 \mathrm{E}+01$ \\
\hline 700 & $1.3 \mathrm{E}+02$ & $2.6 \mathrm{E}+01$ & $3.0 \mathrm{E}+01$ & $1.4 \mathrm{E}+01$ & $6.5 \mathrm{E}+00$ & $5.4 \mathrm{E}+00$ & $1.5 \mathrm{E}+01$ \\
\hline 750 & $1.4 \mathrm{E}+02$ & 2.7E+01 & $3.1 \mathrm{E}+01$ & $1.4 \mathrm{E}+01$ & $6.6 \mathrm{E}+00$ & $5.5 \mathrm{E}+00$ & $1.5 \mathrm{E}+01$ \\
\hline 800 & $1.4 \mathrm{E}+02$ & $2.8 \mathrm{E}+01$ & $3.1 \mathrm{E}+01$ & $1.5 \mathrm{E}+01$ & $6.8 \mathrm{E}+00$ & $5.5 \mathrm{E}+00$ & $1.5 \mathrm{E}+01$ \\
\hline 850 & $1.4 \mathrm{E}+02$ & $2.8 \mathrm{E}+01$ & $3.1 \mathrm{E}+01$ & $1.5 \mathrm{E}+01$ & $6.9 \mathrm{E}+00$ & $5.6 \mathrm{E}+00$ & $1.5 \mathrm{E}+01$ \\
\hline 900 & $1.5 \mathrm{E}+02$ & $2.9 \mathrm{E}+01$ & $3.2 \mathrm{E}+01$ & $1.5 \mathrm{E}+01$ & $7.0 \mathrm{E}+00$ & $5.7 E+00$ & $1.5 \mathrm{E}+01$ \\
\hline 950 & $1.5 \mathrm{E}+02$ & $3.0 \mathrm{E}+01$ & $3.2 \mathrm{E}+01$ & $1.6 \mathrm{E}+01$ & $7.2 \mathrm{E}+00$ & $5.7 E+00$ & $1.6 \mathrm{E}+01$ \\
\hline 1,000 & $1.5 \mathrm{E}+02$ & $3.0 \mathrm{E}+01$ & $3.2 \mathrm{E}+01$ & $1.6 \mathrm{E}+01$ & $7.3 \mathrm{E}+00$ & $5.8 \mathrm{E}+00$ & $1.6 \mathrm{E}+01$ \\
\hline 1,050 & $1.5 \mathrm{E}+02$ & $3.1 \mathrm{E}+01$ & $3.2 \mathrm{E}+01$ & $1.6 \mathrm{E}+01$ & $7.4 \mathrm{E}+00$ & $5.8 \mathrm{E}+00$ & $1.6 \mathrm{E}+01$ \\
\hline 1,100 & $1.5 \mathrm{E}+02$ & $3.1 \mathrm{E}+01$ & $3.3 \mathrm{E}+01$ & $1.6 \mathrm{E}+01$ & $7.5 \mathrm{E}+00$ & $5.9 \mathrm{E}+00$ & $1.6 \mathrm{E}+01$ \\
\hline 2,000 & $1.8 \mathrm{E}+02$ & $3.6 \mathrm{E}+01$ & $3.3 E+01$ & 1.7E+01 & $7.9 \mathrm{E}+00$ & $6.6 \mathrm{E}+00$ & $1.7 \mathrm{E}+01$ \\
\hline 3,000 & $1.9 \mathrm{E}+02$ & $3.9 \mathrm{E}+01$ & $3.4 \mathrm{E}+01$ & $1.8 \mathrm{E}+01$ & $8.5 E+00$ & $6.9 \mathrm{E}+00$ & $1.8 \mathrm{E}+01$ \\
\hline 4,000 & $1.9 \mathrm{E}+02$ & $4.2 \mathrm{E}+01$ & $3.5 \mathrm{E}+01$ & $1.9 \mathrm{E}+01$ & $8.9 E+00$ & $7.1 \mathrm{E}+00$ & $1.8 \mathrm{E}+01$ \\
\hline 5,000 & $2.0 \mathrm{E}+02$ & $4.4 \mathrm{E}+01$ & $3.5 \mathrm{E}+01$ & $2.0 \mathrm{E}+01$ & $9.3 \mathrm{E}+00$ & $7.3 \mathrm{E}+00$ & $1.8 \mathrm{E}+01$ \\
\hline 6,000 & $2.0 \mathrm{E}+02$ & $4.6 \mathrm{E}+01$ & $3.5 \mathrm{E}+01$ & $2.0 \mathrm{E}+01$ & $9.6 \mathrm{E}+00$ & $7.4 \mathrm{E}+00$ & $1.8 \mathrm{E}+01$ \\
\hline 7,000 & $2.0 \mathrm{E}+02$ & 4.7E+01 & $3.6 \mathrm{E}+01$ & $2.1 \mathrm{E}+01$ & $9.8 \mathrm{E}+00$ & $7.5 \mathrm{E}+00$ & $1.8 \mathrm{E}+01$ \\
\hline 8,000 & $2.0 \mathrm{E}+02$ & $4.8 \mathrm{E}+01$ & $3.6 \mathrm{E}+01$ & $2.1 \mathrm{E}+01$ & $1.0 \mathrm{E}+01$ & $7.6 \mathrm{E}+00$ & $1.9 \mathrm{E}+01$ \\
\hline 9,000 & $2.0 \mathrm{E}+02$ & $4.9 \mathrm{E}+01$ & $3.6 \mathrm{E}+01$ & $2.1 \mathrm{E}+01$ & $1.0 \mathrm{E}+01$ & 7.7E+00 & $1.9 \mathrm{E}+01$ \\
\hline 10,000 & $2.0 \mathrm{E}+02$ & $5.0 \mathrm{E}+01$ & $3.6 \mathrm{E}+01$ & $2.1 \mathrm{E}+01$ & $1.0 \mathrm{E}+01$ & $7.8 \mathrm{E}+00$ & $1.9 \mathrm{E}+01$ \\
\hline 11,000 & $2.0 \mathrm{E}+02$ & $5.1 \mathrm{E}+01$ & $3.6 \mathrm{E}+01$ & $2.2 \mathrm{E}+01$ & $1.1 \mathrm{E}+01$ & $7.8 \mathrm{E}+00$ & $1.9 \mathrm{E}+01$ \\
\hline 12,000 & $2.0 \mathrm{E}+02$ & $5.2 \mathrm{E}+01$ & $3.6 \mathrm{E}+01$ & $2.2 \mathrm{E}+01$ & $1.1 \mathrm{E}+01$ & $7.9 \mathrm{E}+00$ & $1.9 \mathrm{E}+01$ \\
\hline 13,000 & $2.0 \mathrm{E}+02$ & $5.2 \mathrm{E}+01$ & $3.6 \mathrm{E}+01$ & $2.2 \mathrm{E}+01$ & $1.1 \mathrm{E}+01$ & $8.0 \mathrm{E}+00$ & $1.9 \mathrm{E}+01$ \\
\hline 14,000 & $2.0 \mathrm{E}+02$ & $5.3 \mathrm{E}+01$ & $3.6 \mathrm{E}+01$ & $2.2 \mathrm{E}+01$ & $1.1 \mathrm{E}+01$ & $8.0 \mathrm{E}+00$ & $1.9 \mathrm{E}+01$ \\
\hline 15,000 & $2.0 \mathrm{E}+02$ & $5.4 \mathrm{E}+01$ & $3.6 \mathrm{E}+01$ & $2.2 \mathrm{E}+01$ & $1.1 \mathrm{E}+01$ & $8.1 \mathrm{E}+00$ & $1.9 \mathrm{E}+01$ \\
\hline 16,000 & $2.0 \mathrm{E}+02$ & $5.4 \mathrm{E}+01$ & $3.6 \mathrm{E}+01$ & $2.3 \mathrm{E}+01$ & $1.1 \mathrm{E}+01$ & $8.1 \mathrm{E}+00$ & $1.9 \mathrm{E}+01$ \\
\hline 17,000 & $2.0 \mathrm{E}+02$ & $5.5 \mathrm{E}+01$ & $3.6 \mathrm{E}+01$ & $2.3 \mathrm{E}+01$ & $1.1 \mathrm{E}+01$ & $8.2 \mathrm{E}+00$ & $1.9 \mathrm{E}+01$ \\
\hline 18,000 & $2.0 \mathrm{E}+02$ & $5.5 \mathrm{E}+01$ & $3.6 \mathrm{E}+01$ & $2.3 \mathrm{E}+01$ & $1.2 \mathrm{E}+01$ & $8.2 \mathrm{E}+00$ & $1.9 \mathrm{E}+01$ \\
\hline 19,000 & $2.0 \mathrm{E}+02$ & $5.5 \mathrm{E}+01$ & $3.6 \mathrm{E}+01$ & $2.3 E+01$ & $1.2 \mathrm{E}+01$ & $8.3 E+00$ & $1.9 \mathrm{E}+01$ \\
\hline 20,000 & $2.0 \mathrm{E}+02$ & $5.6 \mathrm{E}+01$ & $3.6 \mathrm{E}+01$ & $2.3 \mathrm{E}+01$ & $1.2 \mathrm{E}+01$ & $8.3 E+00$ & $1.9 \mathrm{E}+01$ \\
\hline
\end{tabular}


medRxiv preprint doi: https://doi.org/10.1101/2020.04.23.20076273; this version posted April 28, 2020. The copyright holder for this preprint (which was not certified by peer review) is the author/funder, who has granted medRxiv a license to display the preprint in perpetuity. It is made available under a CC-BY-NC-ND 4.0 International license .

M Dillon and Particle Model for C Dillon Airborne Disease Transmission

2628 Table E4b. Normalized Time and Space Integrated Particle Air Concentration for a Circle Arc at 2629 the specified distance from the release assuming airborne loss rate $\left(\lambda_{\text {decay }}=1 \mathrm{~h}^{-1}\right)$.

\begin{tabular}{|c|c|c|c|c|c|c|c|}
\hline $\begin{array}{c}\begin{array}{c}\text { Distance } \\
\text { Downwind }\end{array} \\
(\mathrm{m})\end{array}$ & $\begin{array}{c}\text { Clear, cold } \\
\text { night with } \\
\text { light winds } \\
\left(\mathrm{s} \mathrm{m}^{-2}\right)\end{array}$ & $\begin{array}{c}\text { Clear night } \\
\text { with } \\
\text { gentle } \\
\text { breeze } \\
\left(\mathrm{s} \mathrm{m}^{-2}\right)\end{array}$ & $\begin{array}{c}\text { Overcast } \\
\text { with light } \\
\text { winds } \\
\left(s^{-2}\right)\end{array}$ & $\begin{array}{c}\text { Overcast } \\
\text { with } \\
\text { gentle } \\
\text { winds } \\
\left(\mathrm{s} \mathrm{m}^{-2}\right) \\
\end{array}$ & $\begin{array}{l}\text { Overcast } \\
\text { with } \\
\text { strong } \\
\text { winds } \\
\left(s^{-2}\right) \\
\end{array}$ & $\begin{array}{l}\text { Clear day } \\
\text { with } \\
\text { gentle } \\
\text { winds } \\
\left(\mathbf{s ~ m}^{-2}\right) \\
\end{array}$ & $\begin{array}{c}\text { Clear, hot } \\
\text { day with } \\
\text { light winds } \\
\left(\mathrm{s} \mathrm{m}^{-2}\right)\end{array}$ \\
\hline 50 & $3.8 \mathrm{E}-01$ & $8.0 \mathrm{E}-02$ & $1.3 \mathrm{E}-01$ & $5.4 \mathrm{E}-02$ & $2.4 \mathrm{E}-02$ & $2.4 \mathrm{E}-02$ & $6.8 \mathrm{E}-02$ \\
\hline 100 & $3.2 \mathrm{E}-01$ & $6.3 \mathrm{E}-02$ & $7.8 \mathrm{E}-02$ & $3.6 \mathrm{E}-02$ & $1.6 \mathrm{E}-02$ & $1.3 \mathrm{E}-02$ & $3.4 \mathrm{E}-02$ \\
\hline 150 & 2.7E-01 & $5.2 \mathrm{E}-02$ & $5.3 \mathrm{E}-02$ & 2.7E-02 & $1.2 \mathrm{E}-02$ & $8.8 \mathrm{E}-03$ & $2.2 \mathrm{E}-02$ \\
\hline 200 & $2.3 \mathrm{E}-01$ & 4.3E-02 & $3.9 \mathrm{E}-02$ & $2.1 \mathrm{E}-02$ & $9.8 \mathrm{E}-03$ & $6.4 \mathrm{E}-03$ & $1.5 \mathrm{E}-02$ \\
\hline 250 & 2.0E-01 & $3.8 \mathrm{E}-02$ & $3.1 \mathrm{E}-02$ & $1.8 \mathrm{E}-02$ & 8.2E-03 & $5.0 \mathrm{E}-03$ & $1.2 \mathrm{E}-02$ \\
\hline 300 & $1.8 \mathrm{E}-01$ & $3.3 \mathrm{E}-02$ & $2.5 \mathrm{E}-02$ & $1.5 \mathrm{E}-02$ & 7.0E-03 & $4.1 \mathrm{E}-03$ & $9.4 \mathrm{E}-03$ \\
\hline 350 & $1.6 \mathrm{E}-01$ & $2.9 \mathrm{E}-02$ & $2.1 \mathrm{E}-02$ & $1.3 \mathrm{E}-02$ & $6.1 \mathrm{E}-03$ & $3.4 \mathrm{E}-03$ & 7.6E-03 \\
\hline 400 & $1.4 \mathrm{E}-01$ & 2.7E-02 & $1.8 \mathrm{E}-02$ & $1.2 \mathrm{E}-02$ & $5.4 \mathrm{E}-03$ & $3.0 \mathrm{E}-03$ & $6.4 \mathrm{E}-03$ \\
\hline 450 & $1.2 \mathrm{E}-01$ & 2.4E-02 & $1.5 \mathrm{E}-02$ & $1.0 \mathrm{E}-02$ & $4.9 \mathrm{E}-03$ & 2.6E-03 & 5.5E-03 \\
\hline 500 & $1.1 \mathrm{E}-01$ & $2.2 \mathrm{E}-02$ & $1.3 \mathrm{E}-02$ & $9.4 \mathrm{E}-03$ & $4.4 \mathrm{E}-03$ & $2.3 \mathrm{E}-03$ & $4.8 \mathrm{E}-03$ \\
\hline 550 & $1.0 \mathrm{E}-01$ & $2.0 \mathrm{E}-02$ & $1.2 \mathrm{E}-02$ & $8.6 \mathrm{E}-03$ & $4.0 \mathrm{E}-03$ & $2.0 \mathrm{E}-03$ & $4.2 \mathrm{E}-03$ \\
\hline 600 & $9.3 \mathrm{E}-02$ & $1.9 \mathrm{E}-02$ & $1.1 \mathrm{E}-02$ & 7.9E-03 & 3.7E-03 & $1.8 \mathrm{E}-03$ & 3.7E-03 \\
\hline 650 & $8.5 \mathrm{E}-02$ & $1.8 \mathrm{E}-02$ & $9.5 \mathrm{E}-03$ & 7.3E-03 & $3.5 \mathrm{E}-03$ & $1.7 \mathrm{E}-03$ & 3.3E-03 \\
\hline 700 & $7.8 \mathrm{E}-02$ & $1.6 \mathrm{E}-02$ & $8.6 \mathrm{E}-03$ & $6.9 \mathrm{E}-03$ & $3.2 \mathrm{E}-03$ & $1.5 \mathrm{E}-03$ & 3.0E-03 \\
\hline 750 & $7.2 \mathrm{E}-02$ & $1.5 \mathrm{E}-02$ & $7.8 \mathrm{E}-03$ & $6.4 \mathrm{E}-03$ & $3.0 \mathrm{E}-03$ & $1.4 \mathrm{E}-03$ & 2.7E-03 \\
\hline 800 & $6.5 \mathrm{E}-02$ & $1.4 \mathrm{E}-02$ & 7.1E-03 & $6.0 \mathrm{E}-03$ & $2.9 \mathrm{E}-03$ & $1.3 \mathrm{E}-03$ & $2.5 \mathrm{E}-03$ \\
\hline 850 & $6.0 \mathrm{E}-02$ & $1.4 \mathrm{E}-02$ & $6.5 \mathrm{E}-03$ & $5.6 \mathrm{E}-03$ & 2.7E-03 & $1.2 \mathrm{E}-03$ & $2.3 \mathrm{E}-03$ \\
\hline 900 & $5.5 \mathrm{E}-02$ & $1.3 \mathrm{E}-02$ & $6.0 \mathrm{E}-03$ & $5.4 \mathrm{E}-03$ & $2.6 \mathrm{E}-03$ & $1.1 \mathrm{E}-03$ & 2.1E-03 \\
\hline 950 & $5.0 \mathrm{E}-02$ & $1.2 \mathrm{E}-02$ & $5.5 \mathrm{E}-03$ & 5.1E-03 & $2.4 \mathrm{E}-03$ & $1.0 \mathrm{E}-03$ & $2.0 \mathrm{E}-03$ \\
\hline 1,000 & 4.6E-02 & $1.2 \mathrm{E}-02$ & $5.0 \mathrm{E}-03$ & $4.8 \mathrm{E}-03$ & $2.3 \mathrm{E}-03$ & $9.7 \mathrm{E}-04$ & $1.8 \mathrm{E}-03$ \\
\hline 1,050 & 4.1E-02 & $1.1 \mathrm{E}-02$ & 4.6E-03 & 4.6E-03 & $2.2 \mathrm{E}-03$ & $9.1 \mathrm{E}-04$ & 1.7E-03 \\
\hline 1,100 & 3.6E-02 & $1.1 \mathrm{E}-02$ & $4.1 \mathrm{E}-03$ & 4.3E-03 & 2.1E-03 & $8.4 \mathrm{E}-04$ & $1.5 \mathrm{E}-03$ \\
\hline 2,000 & $1.7 \mathrm{E}-02$ & 4.7E-03 & $1.5 \mathrm{E}-03$ & $1.4 \mathrm{E}-03$ & $7.2 \mathrm{E}-04$ & 4.0E-04 & $6.4 \mathrm{E}-04$ \\
\hline 3,000 & $7.5 \mathrm{E}-03$ & $3.1 \mathrm{E}-03$ & $8.0 \mathrm{E}-04$ & $9.5 \mathrm{E}-04$ & $4.9 \mathrm{E}-04$ & $2.5 \mathrm{E}-04$ & 3.5E-04 \\
\hline 4,000 & $3.9 \mathrm{E}-03$ & 2.3E-03 & $4.9 \mathrm{E}-04$ & $6.9 \mathrm{E}-04$ & $3.8 \mathrm{E}-04$ & $1.8 \mathrm{E}-04$ & $2.2 \mathrm{E}-04$ \\
\hline 5,000 & 2.3E-03 & $1.9 \mathrm{E}-03$ & 3.3E-04 & $5.5 \mathrm{E}-04$ & $3.1 \mathrm{E}-04$ & $1.5 \mathrm{E}-04$ & 1.6E-04 \\
\hline 6,000 & $1.4 \mathrm{E}-03$ & $1.5 \mathrm{E}-03$ & $2.3 \mathrm{E}-04$ & $4.5 \mathrm{E}-04$ & 2.7E-04 & $1.2 \mathrm{E}-04$ & 1.1E-04 \\
\hline 7,000 & $9.3 \mathrm{E}-04$ & $1.3 \mathrm{E}-03$ & 1.7E-04 & $3.8 \mathrm{E}-04$ & $2.3 \mathrm{E}-04$ & $1.1 \mathrm{E}-04$ & 8.4E-05 \\
\hline 8,000 & $6.4 \mathrm{E}-04$ & $1.1 \mathrm{E}-03$ & $1.3 \mathrm{E}-04$ & $3.2 \mathrm{E}-04$ & 2.1E-04 & $9.1 \mathrm{E}-05$ & $6.6 \mathrm{E}-05$ \\
\hline 9,000 & $4.5 \mathrm{E}-04$ & $9.7 \mathrm{E}-04$ & $1.0 \mathrm{E}-04$ & $2.9 \mathrm{E}-04$ & $1.9 \mathrm{E}-04$ & $8.4 \mathrm{E}-05$ & 5.0E-05 \\
\hline 10,000 & $3.2 \mathrm{E}-04$ & $8.6 \mathrm{E}-04$ & 7.4E-05 & $2.5 \mathrm{E}-04$ & $1.8 \mathrm{E}-04$ & 7.7E-05 & 3.8E-05 \\
\hline 11,000 & 2.3E-04 & 7.7E-04 & $5.9 \mathrm{E}-05$ & $2.3 \mathrm{E}-04$ & 1.7E-04 & $7.2 \mathrm{E}-05$ & 2.9E-05 \\
\hline 12,000 & 1.7E-04 & $6.9 \mathrm{E}-04$ & 4.7E-05 & $2.1 \mathrm{E}-04$ & $1.6 \mathrm{E}-04$ & $6.5 \mathrm{E}-05$ & $2.3 \mathrm{E}-05$ \\
\hline 13,000 & $1.3 \mathrm{E}-04$ & $6.3 \mathrm{E}-04$ & 3.6E-05 & $1.9 \mathrm{E}-04$ & $1.5 \mathrm{E}-04$ & $6.0 \mathrm{E}-05$ & $1.9 \mathrm{E}-05$ \\
\hline 14,000 & 9.7E-05 & $5.8 \mathrm{E}-04$ & $2.8 \mathrm{E}-05$ & 1.7E-04 & $1.4 \mathrm{E}-04$ & $5.6 \mathrm{E}-05$ & $1.4 \mathrm{E}-05$ \\
\hline 15,000 & 7.4E-05 & $5.3 \mathrm{E}-04$ & 2.2E-05 & $1.5 \mathrm{E}-04$ & $1.3 \mathrm{E}-04$ & $5.1 \mathrm{E}-05$ & $1.1 \mathrm{E}-05$ \\
\hline 16,000 & 5.7E-05 & $4.8 \mathrm{E}-04$ & 1.7E-05 & $1.4 \mathrm{E}-04$ & $1.2 \mathrm{E}-04$ & $4.8 \mathrm{E}-05$ & $9.2 \mathrm{E}-06$ \\
\hline 17,000 & 4.4E-05 & $4.5 \mathrm{E}-04$ & $1.4 \mathrm{E}-05$ & $1.3 \mathrm{E}-04$ & $1.2 \mathrm{E}-04$ & 4.7E-05 & 7.3E-06 \\
\hline 18,000 & 3.4E-05 & $4.2 \mathrm{E}-04$ & $1.1 \mathrm{E}-05$ & $1.2 \mathrm{E}-04$ & 1.1E-04 & $4.2 \mathrm{E}-05$ & $5.8 \mathrm{E}-06$ \\
\hline 19,000 & 2.7E-05 & $3.8 \mathrm{E}-04$ & 8.7E-06 & 1.1E-04 & 1.1E-04 & $4.2 \mathrm{E}-05$ & 4.6E-06 \\
\hline 20,000 & $2.1 \mathrm{E}-05$ & $3.6 \mathrm{E}-04$ & $6.9 \mathrm{E}-06$ & $1.0 \mathrm{E}-04$ & $1.0 \mathrm{E}-04$ & $3.8 \mathrm{E}-05$ & $3.8 \mathrm{E}-06$ \\
\hline
\end{tabular}


medRxiv preprint doi: https://doi.org/10.1101/2020.04.23.20076273; this version posted April 28, 2020. The copyright holder for this preprint (which was not certified by peer review) is the author/funder, who has granted medRxiv a license to display the preprint in perpetuity. It is made available under a CC-BY-NC-ND 4.0 International license .

M Dillon and Particle Model for C Dillon Airborne Disease Transmission

2631 Table E5a. Normalized Time and Space Integrated Particle Air Concentration for a Disc with 2632 the specified distance from the release assuming airborne loss rate $\left(\lambda_{\text {decay }}=10 \mathrm{~h}^{-1}\right)$.

\begin{tabular}{|c|c|c|c|c|c|c|c|}
\hline $\begin{array}{c}\text { Distance } \\
\text { Downwind } \\
\text { (m) }\end{array}$ & $\begin{array}{c}\text { Clear, cold } \\
\text { night with } \\
\text { light winds } \\
\left(\mathrm{s} \mathrm{m}^{-1}\right)\end{array}$ & $\begin{array}{c}\text { Clear night } \\
\text { with } \\
\text { gentle } \\
\text { breeze } \\
\left(\mathrm{s} \mathrm{m}^{-1}\right)\end{array}$ & $\begin{array}{c}\text { Overcast } \\
\text { with light } \\
\text { winds } \\
\left(\mathbf{s ~ m}^{-1}\right)\end{array}$ & $\begin{array}{l}\text { Overcast } \\
\text { with } \\
\text { gentle } \\
\text { winds } \\
\left(\mathrm{s} \mathrm{m}^{-1}\right)\end{array}$ & $\begin{array}{l}\text { Overcast } \\
\text { with } \\
\text { strong } \\
\text { winds } \\
\left(\mathrm{s} \mathrm{m}^{-1}\right)\end{array}$ & $\begin{array}{l}\text { Clear day } \\
\text { with } \\
\text { gentle } \\
\text { winds } \\
\left(\mathrm{s} \mathrm{m}^{-1}\right)\end{array}$ & $\begin{array}{c}\text { Clear, hot } \\
\text { day with } \\
\text { light winds } \\
\left(\mathrm{s} \mathrm{m}^{-1}\right)\end{array}$ \\
\hline 50 & $1.7 \mathrm{E}+01$ & $4.3 \mathrm{E}+00$ & $9.7 \mathrm{E}+00$ & $3.3 \mathrm{E}+00$ & $1.5 \mathrm{E}+00$ & $2.1 \mathrm{E}+00$ & $6.5 \mathrm{E}+00$ \\
\hline 100 & $2.8 \mathrm{E}+01$ & $7.5 \mathrm{E}+00$ & $1.4 \mathrm{E}+01$ & $5.4 \mathrm{E}+00$ & $2.5 \mathrm{E}+00$ & $2.9 \mathrm{E}+00$ & $8.5 E+00$ \\
\hline 150 & $3.6 \mathrm{E}+01$ & $1.0 \mathrm{E}+01$ & $1.6 \mathrm{E}+01$ & $6.8 \mathrm{E}+00$ & $3.2 E+00$ & $3.4 \mathrm{E}+00$ & $9.4 \mathrm{E}+00$ \\
\hline 200 & $4.1 \mathrm{E}+01$ & $1.2 \mathrm{E}+01$ & $1.7 \mathrm{E}+01$ & $7.8 \mathrm{E}+00$ & $3.7 E+00$ & $3.7 E+00$ & $1.0 \mathrm{E}+01$ \\
\hline 250 & $4.4 \mathrm{E}+01$ & $1.4 \mathrm{E}+01$ & $1.8 \mathrm{E}+01$ & $8.6 \mathrm{E}+00$ & $4.1 \mathrm{E}+00$ & $4.0 \mathrm{E}+00$ & $1.0 \mathrm{E}+01$ \\
\hline 300 & 4.7E+01 & $1.5 \mathrm{E}+01$ & $1.8 \mathrm{E}+01$ & $9.2 \mathrm{E}+00$ & $4.4 \mathrm{E}+00$ & $4.2 \mathrm{E}+00$ & $1.1 \mathrm{E}+01$ \\
\hline 350 & $4.9 \mathrm{E}+01$ & $1.6 \mathrm{E}+01$ & $1.9 \mathrm{E}+01$ & $9.8 \mathrm{E}+00$ & $4.7 E+00$ & $4.3 \mathrm{E}+00$ & $1.1 \mathrm{E}+01$ \\
\hline 400 & $5.1 \mathrm{E}+01$ & 1.7E+01 & $1.9 \mathrm{E}+01$ & $1.0 \mathrm{E}+01$ & $5.0 \mathrm{E}+00$ & $4.4 \mathrm{E}+00$ & $1.1 \mathrm{E}+01$ \\
\hline 450 & $5.2 \mathrm{E}+01$ & $1.8 \mathrm{E}+01$ & $2.0 \mathrm{E}+01$ & $1.1 \mathrm{E}+01$ & $5.2 \mathrm{E}+00$ & $4.6 \mathrm{E}+00$ & $1.1 \mathrm{E}+01$ \\
\hline 500 & $5.3 \mathrm{E}+01$ & $1.8 \mathrm{E}+01$ & $2.0 \mathrm{E}+01$ & $1.1 \mathrm{E}+01$ & $5.4 \mathrm{E}+00$ & $4.6 \mathrm{E}+00$ & $1.1 \mathrm{E}+01$ \\
\hline 550 & $5.3 \mathrm{E}+01$ & $1.9 \mathrm{E}+01$ & $2.0 \mathrm{E}+01$ & $1.1 \mathrm{E}+01$ & $5.5 E+00$ & $4.7 E+00$ & $1.1 \mathrm{E}+01$ \\
\hline 600 & $5.4 \mathrm{E}+01$ & $2.0 \mathrm{E}+01$ & $2.0 \mathrm{E}+01$ & $1.2 \mathrm{E}+01$ & $5.7 E+00$ & $4.8 \mathrm{E}+00$ & $1.1 \mathrm{E}+01$ \\
\hline 650 & $5.4 \mathrm{E}+01$ & $2.0 \mathrm{E}+01$ & $2.0 \mathrm{E}+01$ & $1.2 \mathrm{E}+01$ & $5.8 \mathrm{E}+00$ & $4.8 \mathrm{E}+00$ & $1.1 \mathrm{E}+01$ \\
\hline 700 & $5.5 \mathrm{E}+01$ & $2.1 \mathrm{E}+01$ & $2.0 \mathrm{E}+01$ & $1.2 \mathrm{E}+01$ & $6.0 \mathrm{E}+00$ & $4.9 \mathrm{E}+00$ & $1.1 \mathrm{E}+01$ \\
\hline 750 & $5.5 \mathrm{E}+01$ & $2.1 \mathrm{E}+01$ & $2.0 \mathrm{E}+01$ & $1.2 \mathrm{E}+01$ & $6.1 \mathrm{E}+00$ & $4.9 \mathrm{E}+00$ & $1.1 \mathrm{E}+01$ \\
\hline 800 & $5.5 E+01$ & $2.1 \mathrm{E}+01$ & $2.0 \mathrm{E}+01$ & $1.2 \mathrm{E}+01$ & $6.2 \mathrm{E}+00$ & $5.0 \mathrm{E}+00$ & $1.1 \mathrm{E}+01$ \\
\hline 850 & $5.5 E+01$ & $2.2 \mathrm{E}+01$ & $2.0 \mathrm{E}+01$ & $1.3 \mathrm{E}+01$ & $6.3 E+00$ & $5.0 \mathrm{E}+00$ & $1.1 \mathrm{E}+01$ \\
\hline 900 & $5.5 \mathrm{E}+01$ & $2.2 \mathrm{E}+01$ & $2.0 \mathrm{E}+01$ & $1.3 \mathrm{E}+01$ & $6.4 \mathrm{E}+00$ & $5.1 \mathrm{E}+00$ & $1.1 \mathrm{E}+01$ \\
\hline 950 & $5.5 \mathrm{E}+01$ & $2.2 \mathrm{E}+01$ & $2.0 \mathrm{E}+01$ & $1.3 \mathrm{E}+01$ & $6.5 \mathrm{E}+00$ & $5.1 \mathrm{E}+00$ & $1.1 \mathrm{E}+01$ \\
\hline 1,000 & $5.5 \mathrm{E}+01$ & $2.3 \mathrm{E}+01$ & $2.0 \mathrm{E}+01$ & $1.3 \mathrm{E}+01$ & $6.6 \mathrm{E}+00$ & $5.1 \mathrm{E}+00$ & $1.1 \mathrm{E}+01$ \\
\hline 1,050 & $5.6 \mathrm{E}+01$ & $2.3 \mathrm{E}+01$ & $2.0 \mathrm{E}+01$ & $1.3 \mathrm{E}+01$ & $6.7 \mathrm{E}+00$ & $5.2 \mathrm{E}+00$ & $1.1 \mathrm{E}+01$ \\
\hline 1,100 & $5.6 \mathrm{E}+01$ & $2.3 \mathrm{E}+01$ & $2.1 \mathrm{E}+01$ & $1.3 \mathrm{E}+01$ & $6.8 \mathrm{E}+00$ & $5.2 \mathrm{E}+00$ & $1.1 \mathrm{E}+01$ \\
\hline 2,000 & $6.1 \mathrm{E}+01$ & $2.5 \mathrm{E}+01$ & $2.1 \mathrm{E}+01$ & $1.3 \mathrm{E}+01$ & $7.0 \mathrm{E}+00$ & $5.6 \mathrm{E}+00$ & $1.2 \mathrm{E}+01$ \\
\hline 3,000 & $6.1 \mathrm{E}+01$ & $2.5 \mathrm{E}+01$ & $2.1 \mathrm{E}+01$ & $1.4 \mathrm{E}+01$ & $7.3 E+00$ & $5.7 \mathrm{E}+00$ & $1.2 \mathrm{E}+01$ \\
\hline 4,000 & $6.1 \mathrm{E}+01$ & $2.6 \mathrm{E}+01$ & $2.1 \mathrm{E}+01$ & $1.4 \mathrm{E}+01$ & $7.4 \mathrm{E}+00$ & $5.7 \mathrm{E}+00$ & $1.2 \mathrm{E}+01$ \\
\hline 5,000 & $6.1 \mathrm{E}+01$ & $2.6 \mathrm{E}+01$ & $2.1 \mathrm{E}+01$ & $1.4 \mathrm{E}+01$ & $7.6 \mathrm{E}+00$ & $5.8 \mathrm{E}+00$ & $1.2 \mathrm{E}+01$ \\
\hline 6,000 & $6.1 \mathrm{E}+01$ & $2.6 \mathrm{E}+01$ & $2.1 \mathrm{E}+01$ & $1.4 \mathrm{E}+01$ & $7.6 \mathrm{E}+00$ & $5.8 \mathrm{E}+00$ & $1.2 \mathrm{E}+01$ \\
\hline 7,000 & $6.1 \mathrm{E}+01$ & $2.6 \mathrm{E}+01$ & $2.1 \mathrm{E}+01$ & $1.4 \mathrm{E}+01$ & 7.7E+00 & $5.8 \mathrm{E}+00$ & $1.2 \mathrm{E}+01$ \\
\hline 8,000 & $6.1 \mathrm{E}+01$ & $2.6 \mathrm{E}+01$ & $2.1 \mathrm{E}+01$ & $1.4 \mathrm{E}+01$ & 7.7E+00 & $5.8 \mathrm{E}+00$ & $1.2 \mathrm{E}+01$ \\
\hline 9,000 & $6.1 \mathrm{E}+01$ & $2.6 \mathrm{E}+01$ & $2.1 \mathrm{E}+01$ & $1.4 \mathrm{E}+01$ & $7.8 \mathrm{E}+00$ & $5.8 \mathrm{E}+00$ & $1.2 \mathrm{E}+01$ \\
\hline 10,000 & $6.1 \mathrm{E}+01$ & $2.6 \mathrm{E}+01$ & $2.1 \mathrm{E}+01$ & $1.4 \mathrm{E}+01$ & $7.8 \mathrm{E}+00$ & $5.8 \mathrm{E}+00$ & $1.2 \mathrm{E}+01$ \\
\hline 11,000 & $6.1 \mathrm{E}+01$ & $2.6 \mathrm{E}+01$ & $2.1 \mathrm{E}+01$ & $1.4 \mathrm{E}+01$ & $7.8 \mathrm{E}+00$ & $5.8 \mathrm{E}+00$ & $1.2 \mathrm{E}+01$ \\
\hline 12,000 & $6.1 \mathrm{E}+01$ & $2.6 \mathrm{E}+01$ & $2.1 \mathrm{E}+01$ & $1.4 \mathrm{E}+01$ & $7.8 \mathrm{E}+00$ & $5.8 \mathrm{E}+00$ & $1.2 \mathrm{E}+01$ \\
\hline 13,000 & $6.1 \mathrm{E}+01$ & $2.6 \mathrm{E}+01$ & $2.1 \mathrm{E}+01$ & $1.4 \mathrm{E}+01$ & $7.8 \mathrm{E}+00$ & $5.8 \mathrm{E}+00$ & $1.2 \mathrm{E}+01$ \\
\hline 14,000 & $6.1 \mathrm{E}+01$ & $2.6 \mathrm{E}+01$ & $2.1 \mathrm{E}+01$ & $1.4 \mathrm{E}+01$ & $7.8 \mathrm{E}+00$ & $5.8 \mathrm{E}+00$ & $1.2 \mathrm{E}+01$ \\
\hline 15,000 & $6.1 \mathrm{E}+01$ & $2.6 \mathrm{E}+01$ & $2.1 \mathrm{E}+01$ & $1.4 \mathrm{E}+01$ & $7.8 \mathrm{E}+00$ & $5.8 \mathrm{E}+00$ & $1.2 \mathrm{E}+01$ \\
\hline 16,000 & $6.1 \mathrm{E}+01$ & $2.6 \mathrm{E}+01$ & $2.1 \mathrm{E}+01$ & $1.4 \mathrm{E}+01$ & $7.8 \mathrm{E}+00$ & $5.8 \mathrm{E}+00$ & $1.2 \mathrm{E}+01$ \\
\hline 17,000 & $6.1 \mathrm{E}+01$ & $2.6 \mathrm{E}+01$ & $2.1 E+01$ & $1.4 \mathrm{E}+01$ & $7.9 \mathrm{E}+00$ & $5.8 \mathrm{E}+00$ & $1.2 \mathrm{E}+01$ \\
\hline 18,000 & $6.1 \mathrm{E}+01$ & $2.6 \mathrm{E}+01$ & $2.1 \mathrm{E}+01$ & $1.4 \mathrm{E}+01$ & $7.9 \mathrm{E}+00$ & $5.8 \mathrm{E}+00$ & $1.2 \mathrm{E}+01$ \\
\hline 19,000 & $6.1 \mathrm{E}+01$ & $2.6 \mathrm{E}+01$ & $2.1 \mathrm{E}+01$ & $1.4 \mathrm{E}+01$ & $7.9 \mathrm{E}+00$ & $5.8 \mathrm{E}+00$ & $1.2 \mathrm{E}+01$ \\
\hline 20,000 & $6.1 \mathrm{E}+01$ & $2.6 \mathrm{E}+01$ & $2.1 \mathrm{E}+01$ & $1.4 \mathrm{E}+01$ & $7.9 \mathrm{E}+00$ & $5.8 \mathrm{E}+00$ & $1.2 \mathrm{E}+01$ \\
\hline
\end{tabular}


medRxiv preprint doi: https://doi.org/10.1101/2020.04.23.20076273; this version posted April 28, 2020. The copyright holder for this preprint (which was not certified by peer review) is the author/funder, who has granted medRxiv a license to display the preprint in perpetuity. It is made available under a CC-BY-NC-ND 4.0 International license .

M Dillon and Particle Model for C Dillon Airborne Disease Transmission

2634 Table E5b. Normalized Time and Space Integrated Particle Air Concentration for a Circle Arc at 2635 the specified distance from the release assuming airborne loss rate $\left(\lambda_{\text {decay }}=10 \mathrm{~h}^{-1}\right)$.

\begin{tabular}{|c|c|c|c|c|c|c|c|}
\hline $\begin{array}{c}\begin{array}{c}\text { Distance } \\
\text { Downwind }\end{array} \\
(\mathrm{m})\end{array}$ & $\begin{array}{c}\text { Clear, cold } \\
\text { night with } \\
\text { light winds } \\
\left(\mathrm{s} \mathrm{m}^{-2}\right)\end{array}$ & $\begin{array}{c}\text { Clear night } \\
\text { with } \\
\text { gentle } \\
\text { breeze } \\
\left(\mathrm{s} \mathrm{m}^{-2}\right)\end{array}$ & $\begin{array}{c}\text { Overcast } \\
\text { with light } \\
\text { winds } \\
\left(s^{-2}\right)\end{array}$ & $\begin{array}{c}\text { Overcast } \\
\text { with } \\
\text { gentle } \\
\text { winds } \\
\left(\mathrm{s} \mathrm{m}^{-2}\right) \\
\end{array}$ & $\begin{array}{c}\text { Overcast } \\
\text { with } \\
\text { strong } \\
\text { winds } \\
\left(\mathbf{s ~ m}^{-2}\right) \\
\end{array}$ & $\begin{array}{c}\text { Clear day } \\
\text { with } \\
\text { gentle } \\
\text { winds } \\
\left(\mathrm{s} \mathrm{m}^{-2}\right) \\
\end{array}$ & $\begin{array}{c}\text { Clear, hot } \\
\text { day with } \\
\text { light winds } \\
\left(\mathrm{s} \mathrm{m}^{-2}\right)\end{array}$ \\
\hline 50 & 2.7E-01 & $7.5 \mathrm{E}-02$ & $1.1 \mathrm{E}-01$ & 5.1E-02 & $2.4 \mathrm{E}-02$ & $2.3 \mathrm{E}-02$ & 5.7E-02 \\
\hline 100 & $1.8 \mathrm{E}-01$ & $5.6 \mathrm{E}-02$ & $5.5 \mathrm{E}-02$ & $3.3 \mathrm{E}-02$ & $1.6 \mathrm{E}-02$ & $1.2 \mathrm{E}-02$ & $2.5 \mathrm{E}-02$ \\
\hline 150 & $1.2 \mathrm{E}-01$ & 4. $4 \mathrm{E}-02$ & 3.3E-02 & $2.4 \mathrm{E}-02$ & $1.2 \mathrm{E}-02$ & 7.9E-03 & $1.4 \mathrm{E}-02$ \\
\hline 200 & $8.6 \mathrm{E}-02$ & $3.5 \mathrm{E}-02$ & $2.1 \mathrm{E}-02$ & $1.8 \mathrm{E}-02$ & $9.0 \mathrm{E}-03$ & $5.6 \mathrm{E}-03$ & $9.0 \mathrm{E}-03$ \\
\hline 250 & $6.3 \mathrm{E}-02$ & $2.9 \mathrm{E}-02$ & $1.5 \mathrm{E}-02$ & $1.4 \mathrm{E}-02$ & 7.4E-03 & $4.2 \mathrm{E}-03$ & $6.2 \mathrm{E}-03$ \\
\hline 300 & 4.6E-02 & 2.4E-02 & $1.1 \mathrm{E}-02$ & $1.2 \mathrm{E}-02$ & $6.2 \mathrm{E}-03$ & $3.4 \mathrm{E}-03$ & 4.4E-03 \\
\hline 350 & $3.4 \mathrm{E}-02$ & 2.1E-02 & $7.9 \mathrm{E}-03$ & $9.8 \mathrm{E}-03$ & 5.3E-03 & $2.8 \mathrm{E}-03$ & $3.2 \mathrm{E}-03$ \\
\hline 400 & 2.6E-02 & $1.8 \mathrm{E}-02$ & $6.0 \mathrm{E}-03$ & $8.4 \mathrm{E}-03$ & 4.7E-03 & 2.3E-03 & 2.4E-03 \\
\hline 450 & 2.0E-02 & $1.6 \mathrm{E}-02$ & $4.6 \mathrm{E}-03$ & 7.3E-03 & 4.1E-03 & 2.0E-03 & 1.9E-03 \\
\hline 500 & $1.5 \mathrm{E}-02$ & $1.4 \mathrm{E}-02$ & $3.6 \mathrm{E}-03$ & $6.4 \mathrm{E}-03$ & 3.7E-03 & 1.7E-03 & $1.5 \mathrm{E}-03$ \\
\hline 550 & $1.2 \mathrm{E}-02$ & $1.2 \mathrm{E}-02$ & $2.9 \mathrm{E}-03$ & $5.6 \mathrm{E}-03$ & 3.3E-03 & $1.5 \mathrm{E}-03$ & $1.2 \mathrm{E}-03$ \\
\hline 600 & $9.3 \mathrm{E}-03$ & $1.1 \mathrm{E}-02$ & $2.3 \mathrm{E}-03$ & 5.0E-03 & 3.0E-03 & $1.3 \mathrm{E}-03$ & $9.4 \mathrm{E}-04$ \\
\hline 650 & 7.3E-03 & $9.6 \mathrm{E}-03$ & $1.9 \mathrm{E}-03$ & $4.5 \mathrm{E}-03$ & $2.8 \mathrm{E}-03$ & 1.1E-03 & 7.5E-04 \\
\hline 700 & $5.7 \mathrm{E}-03$ & $8.6 \mathrm{E}-03$ & $1.5 \mathrm{E}-03$ & 4.1E-03 & $2.5 \mathrm{E}-03$ & 1.0E-03 & 6.1E-04 \\
\hline 750 & 4.6E-03 & $7.8 \mathrm{E}-03$ & $1.3 \mathrm{E}-03$ & 3.7E-03 & $2.4 \mathrm{E}-03$ & $9.0 \mathrm{E}-04$ & 5.1E-04 \\
\hline 800 & 3.6E-03 & 7.0E-03 & $1.0 \mathrm{E}-03$ & $3.4 \mathrm{E}-03$ & $2.2 \mathrm{E}-03$ & 8.1E-04 & 4.3E-04 \\
\hline 850 & $2.9 \mathrm{E}-03$ & $6.5 \mathrm{E}-03$ & $8.6 \mathrm{E}-04$ & 3.1E-03 & 2.1E-03 & 7.4E-04 & 3.6E-04 \\
\hline 900 & 2.3E-03 & $5.9 \mathrm{E}-03$ & $7.2 \mathrm{E}-04$ & $2.8 \mathrm{E}-03$ & 1.9E-03 & 6.7E-04 & 3.0E-04 \\
\hline 950 & $1.8 \mathrm{E}-03$ & $5.4 \mathrm{E}-03$ & $6.0 \mathrm{E}-04$ & $2.6 \mathrm{E}-03$ & $1.8 \mathrm{E}-03$ & $6.0 \mathrm{E}-04$ & $2.5 \mathrm{E}-04$ \\
\hline 1,000 & $1.5 \mathrm{E}-03$ & $5.0 \mathrm{E}-03$ & $5.0 \mathrm{E}-04$ & $2.4 \mathrm{E}-03$ & 1.7E-03 & 5.6E-04 & 2.1E-04 \\
\hline 1,050 & $1.2 \mathrm{E}-03$ & 4.6E-03 & $4.2 \mathrm{E}-04$ & $2.2 \mathrm{E}-03$ & $1.6 \mathrm{E}-03$ & $5.2 \mathrm{E}-04$ & $1.8 \mathrm{E}-04$ \\
\hline 1,100 & $9.2 \mathrm{E}-04$ & $4.2 \mathrm{E}-03$ & $3.4 \mathrm{E}-04$ & $2.0 \mathrm{E}-03$ & $1.5 \mathrm{E}-03$ & 4.7E-04 & $1.5 \mathrm{E}-04$ \\
\hline 2,000 & 4.9E-05 & $1.1 \mathrm{E}-03$ & $2.3 \mathrm{E}-05$ & 4.1E-04 & 4.0E-04 & $1.4 \mathrm{E}-04$ & $1.2 \mathrm{E}-05$ \\
\hline 3,000 & 2.6E-06 & $4.1 \mathrm{E}-04$ & 2.1E-06 & 1.7E-04 & $2.2 \mathrm{E}-04$ & 5.5E-05 & 1.0E-06 \\
\hline 4,000 & 2.0E-07 & $1.9 \mathrm{E}-04$ & $2.5 \mathrm{E}-07$ & $7.6 \mathrm{E}-05$ & 1.4E-04 & $2.6 \mathrm{E}-05$ & 1.1E-07 \\
\hline 5,000 & 2.1E-08 & 9.7E-05 & 3.3E-08 & $3.9 \mathrm{E}-05$ & 9.3E-05 & $1.4 \mathrm{E}-05$ & $1.4 \mathrm{E}-08$ \\
\hline 6,000 & 2.2E-09 & $5.2 \mathrm{E}-05$ & 4.4E-09 & $2.1 \mathrm{E}-05$ & $6.6 \mathrm{E}-05$ & 7.4E-06 & 1.7E-09 \\
\hline 7,000 & $2.2 \mathrm{E}-10$ & $2.9 \mathrm{E}-05$ & $6.0 \mathrm{E}-10$ & 1.1E-05 & 4.7E-05 & $4.2 \mathrm{E}-06$ & $1.9 \mathrm{E}-10$ \\
\hline 8,000 & $1.3 \mathrm{E}-11$ & 1.7E-05 & $6.4 \mathrm{E}-11$ & $6.5 \mathrm{E}-06$ & $3.5 \mathrm{E}-05$ & $2.4 \mathrm{E}-06$ & 1.7E-11 \\
\hline 9,000 & 3.7E-13 & $1.0 \mathrm{E}-05$ & $3.2 \mathrm{E}-12$ & $3.8 \mathrm{E}-06$ & 2.7E-05 & $1.4 \mathrm{E}-06$ & $5.5 \mathrm{E}-13$ \\
\hline 10,000 & $0.0 \mathrm{E}+00$ & $6.3 \mathrm{E}-06$ & $9.3 \mathrm{E}-14$ & $2.2 \mathrm{E}-06$ & $2.0 \mathrm{E}-05$ & 8.5E-07 & $0.0 \mathrm{E}+00$ \\
\hline 11,000 & $0.0 \mathrm{E}+00$ & $3.9 \mathrm{E}-06$ & $0.0 \mathrm{E}+00$ & $1.3 \mathrm{E}-06$ & 1.6E-05 & $5.3 \mathrm{E}-07$ & $0.0 \mathrm{E}+00$ \\
\hline 12,000 & $0.0 \mathrm{E}+00$ & $2.5 \mathrm{E}-06$ & $0.0 \mathrm{E}+00$ & 8.1E-07 & $1.2 \mathrm{E}-05$ & 3.1E-07 & $0.0 \mathrm{E}+00$ \\
\hline 13,000 & $0.0 \mathrm{E}+00$ & $1.6 \mathrm{E}-06$ & $0.0 \mathrm{E}+00$ & 5.0E-07 & $9.6 \mathrm{E}-06$ & 1.9E-07 & $0.0 \mathrm{E}+00$ \\
\hline 14,000 & $0.0 E+00$ & $1.0 \mathrm{E}-06$ & $0.0 E+00$ & $3.0 \mathrm{E}-07$ & 7.6E-06 & 1.1E-07 & $0.0 \mathrm{E}+00$ \\
\hline 15,000 & $0.0 E+00$ & $6.8 \mathrm{E}-07$ & $0.0 \mathrm{E}+00$ & $1.8 \mathrm{E}-07$ & $5.8 \mathrm{E}-06$ & $6.8 \mathrm{E}-08$ & $0.0 \mathrm{E}+00$ \\
\hline 16,000 & $0.0 \mathrm{E}+00$ & 4.4E-07 & $0.0 \mathrm{E}+00$ & 1.1E-07 & 4.6E-06 & 4.3E-08 & $0.0 \mathrm{E}+00$ \\
\hline 17,000 & $0.0 \mathrm{E}+00$ & $3.0 \mathrm{E}-07$ & $0.0 \mathrm{E}+00$ & $6.9 \mathrm{E}-08$ & 3.7E-06 & 2.7E-08 & $0.0 \mathrm{E}+00$ \\
\hline 18,000 & $0.0 \mathrm{E}+00$ & $1.9 \mathrm{E}-07$ & $0.0 \mathrm{E}+00$ & $4.2 \mathrm{E}-08$ & $3.0 \mathrm{E}-06$ & $1.6 \mathrm{E}-08$ & $0.0 \mathrm{E}+00$ \\
\hline 19,000 & $0.0 \mathrm{E}+00$ & $1.3 \mathrm{E}-07$ & $0.0 \mathrm{E}+00$ & $2.6 \mathrm{E}-08$ & $2.3 \mathrm{E}-06$ & 1.0E-08 & $0.0 \mathrm{E}+00$ \\
\hline 20,000 & $0.0 \mathrm{E}+00$ & 8.7E-08 & $0.0 \mathrm{E}+00$ & $1.7 \mathrm{E}-08$ & 1.9E-06 & $6.2 \mathrm{E}-09$ & $0.0 \mathrm{E}+00$ \\
\hline
\end{tabular}


medRxiv preprint doi: https://doi.org/10.1101/2020.04.23.20076273; this version posted April 28, 2020. The copyright holder for this preprint (which was not certified by peer review) is the author/funder, who has granted medRxiv a license to display the preprint in perpetuity. It is made available under a CC-BY-NC-ND 4.0 International license .

M Dillon and C Dillon
Particle Model for Airborne Disease Transmission
2638

2639

2640

2641

2642

2643

Figure E1. Predicted absolute infection probabilities and infections by distance, wind speed and atmospheric stability for a single airborne particle with $0 \mathrm{~h}^{-1}$ airborne loss of infectivity. Legend indicates Pasquill-Gifford-Turner atmospheric stability class ( $A$ to $F$ ) and the $10 \mathrm{~m}$ agl wind speed. Individual person infection probability (top panels) is dimensionless. Urban area infections (bottom panels) assumes a uniform population density of 0.01 people $\mathrm{m}^{-2}$ and has dimensions of people (disc) or people $\mathrm{m}^{-1}(\operatorname{arc})$.

Figure E1a. Infection Probabilities and Urban Infections Within a Disc Centered on the Release
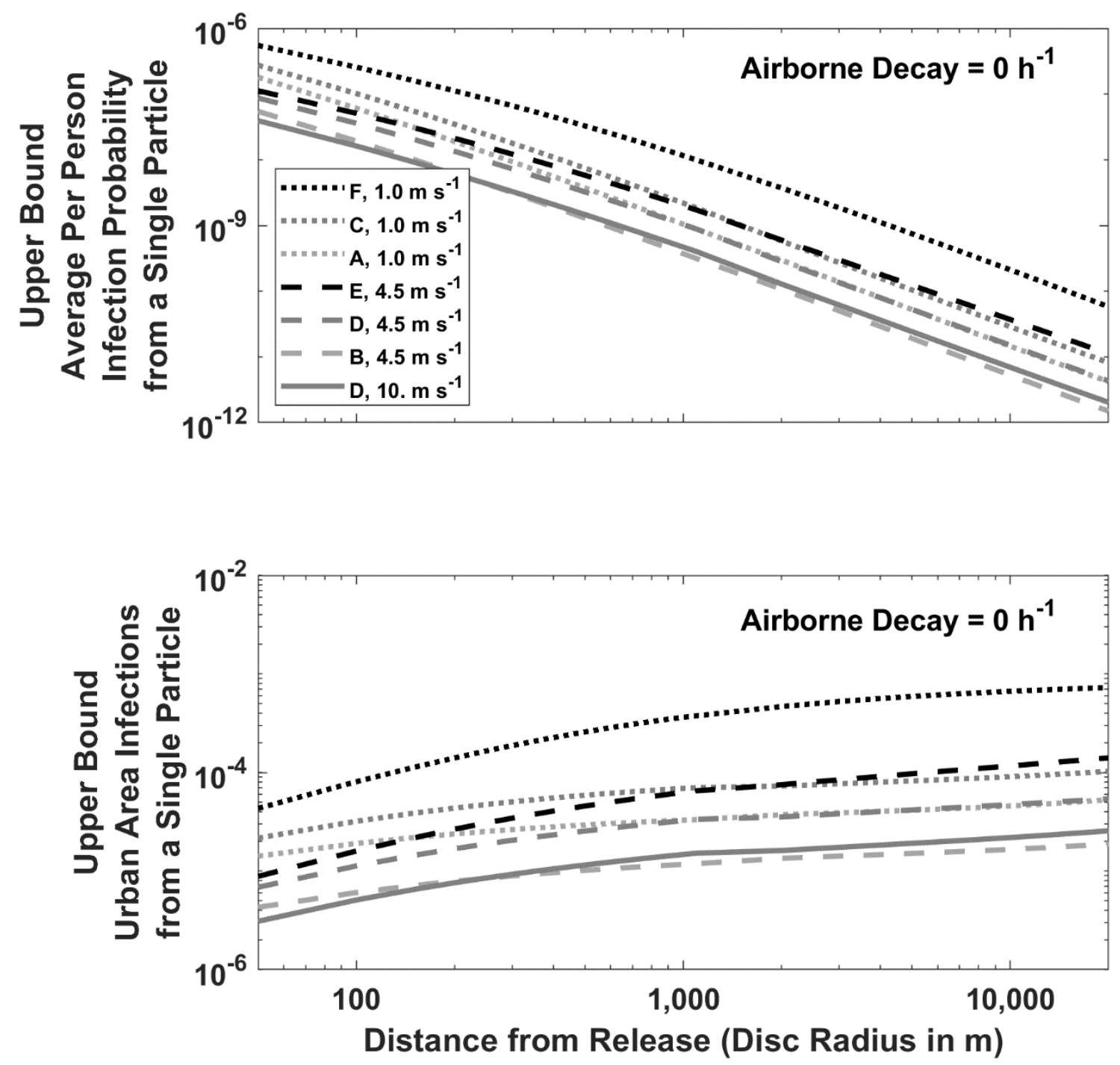
medRxiv preprint doi: https://doi.org/10.1101/2020.04.23.20076273; this version posted April 28, 2020. The copyright holder for this preprint (which was not certified by peer review) is the author/funder, who has granted medRxiv a license to display the preprint in perpetuity. It is made available under a CC-BY-NC-ND 4.0 International license .

M Dillon and Particle Model for C Dillon Airborne Disease Transmission

Figure E1b. Infection Probabilities and Urban Infections Along an Arc Centered on the Release Source
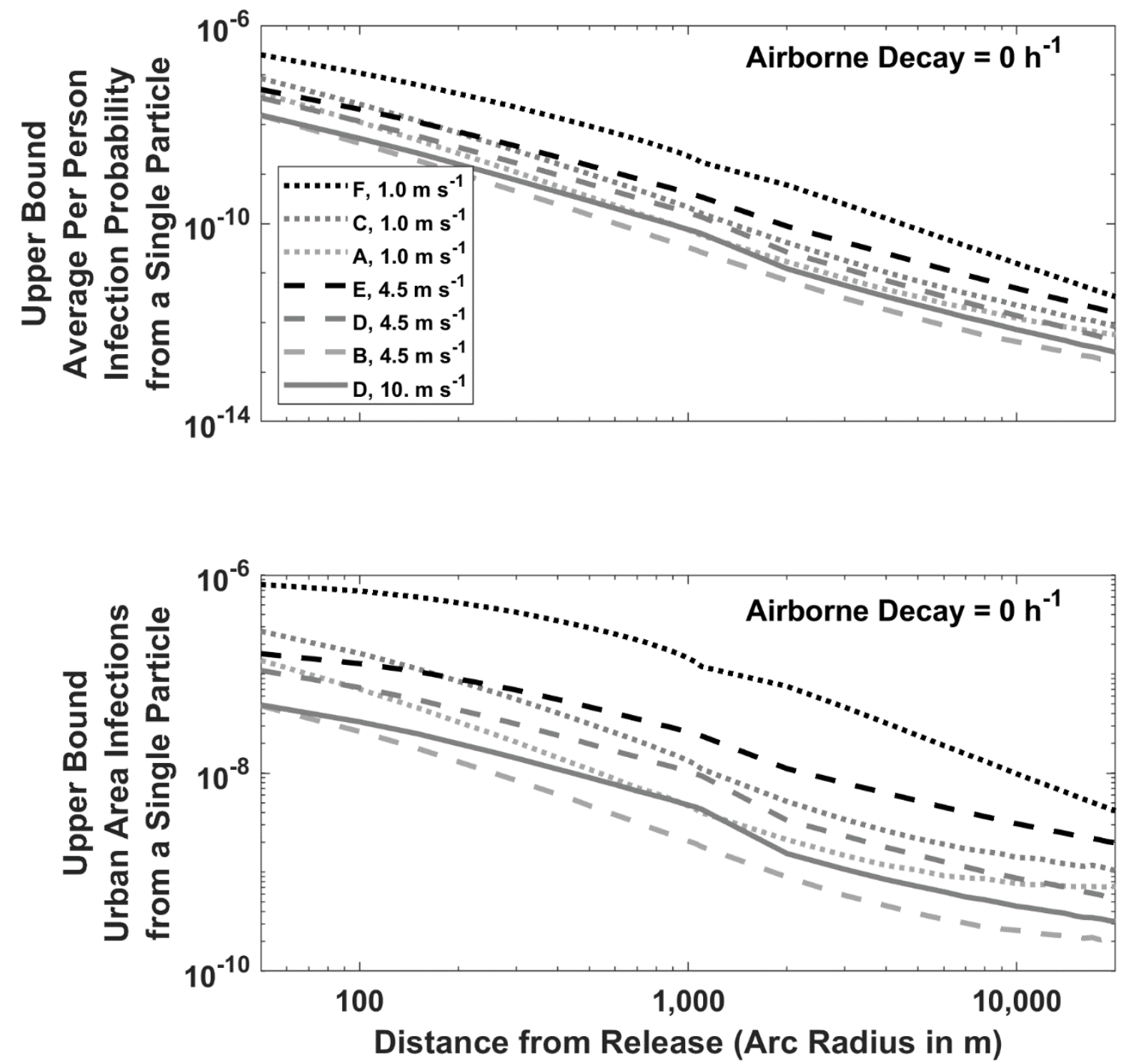
medRxiv preprint doi: https://doi.org/10.1101/2020.04.23.20076273; this version posted April 28, 2020. The copyright holder for this preprint (which was not certified by peer review) is the author/funder, who has granted medRxiv a license to display the preprint in perpetuity. It is made available under a CC-BY-NC-ND 4.0 International license .

M Dillon and C Dillon
Particle Model for Airborne Disease Transmission
2648

Figure E2. Predicted absolute infection probabilities and infections by distance, wind speed and atmospheric stability for a single airborne particle with $0.1 \mathrm{~h}^{-1}$ airborne loss of infectivity. Legend indicates Pasquill-Gifford-Turner atmospheric stability class ( $A$ to $F$ ) and the $10 \mathrm{~m}$ agl wind speed. Individual person infection probability (top panels) is dimensionless. Urban area infections (bottom panels) assumes a uniform population density of 0.01 people $\mathrm{m}^{-2}$ and has dimensions of people (disc) or people $\mathrm{m}^{-1}(\operatorname{arc})$.

Figure E2a. Infection Probabilities and Urban Infections Within a Disc Centered on the Release
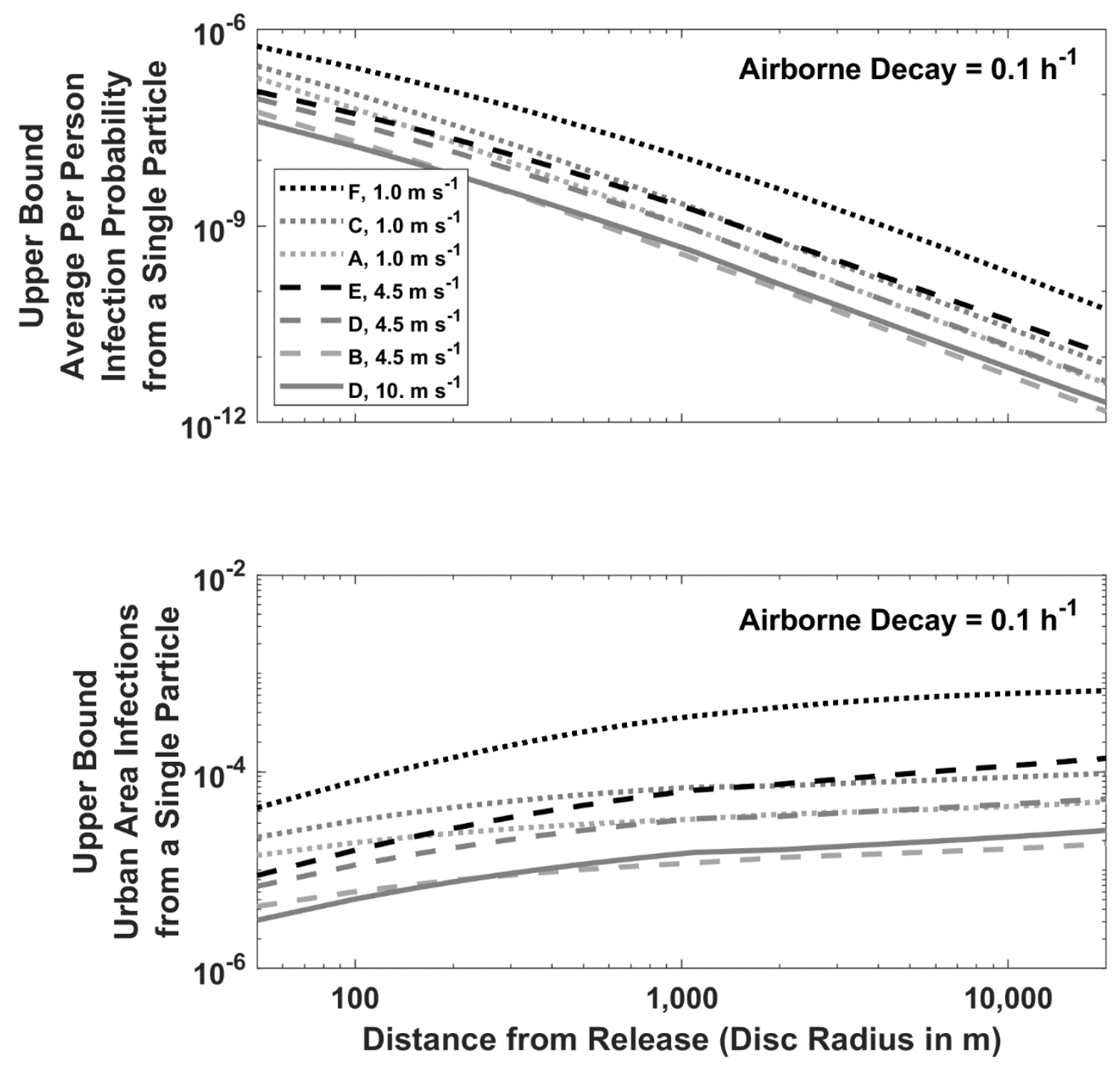
medRxiv preprint doi: https://doi.org/10.1101/2020.04.23.20076273; this version posted April 28, 2020. The copyright holder for this preprint (which was not certified by peer review) is the author/funder, who has granted medRxiv a license to display the preprint in perpetuity. It is made available under a CC-BY-NC-ND 4.0 International license .

M Dillon and Particle Model for C Dillon Airborne Disease Transmission

Figure E2b. Infection Probabilities and Urban Infections Along an Arc Centered on the Release Source
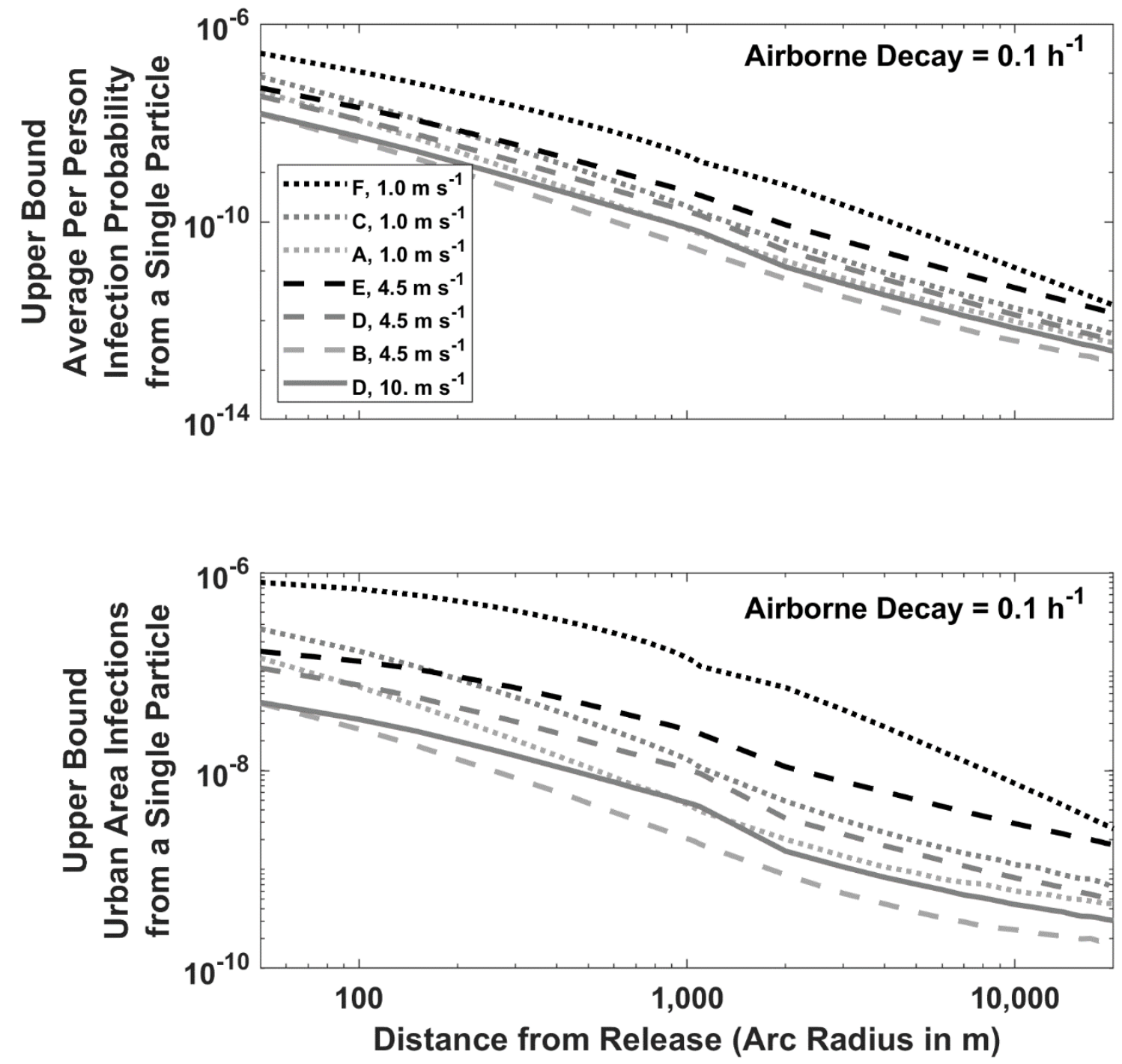
medRxiv preprint doi: https://doi.org/10.1101/2020.04.23.20076273; this version posted April 28, 2020. The copyright holder for this preprint (which was not certified by peer review) is the author/funder, who has granted medRxiv a license to display the preprint in perpetuity. It is made available under a CC-BY-NC-ND 4.0 International license .

M Dillon and C Dillon
Particle Model for Airborne Disease Transmission
2658

2659

2660

2661

2662

2663

Figure E3. Predicted absolute infection probabilities and infections by distance, wind speed and atmospheric stability for a single airborne particle with $1 \mathrm{~h}^{-1}$ airborne loss of infectivity. Legend indicates Pasquill-Gifford-Turner atmospheric stability class ( $A$ to $F$ ) and the $10 \mathrm{~m}$ agl wind speed. Individual person infection probability (top panels) is dimensionless. Urban area infections (bottom panels) assumes a uniform population density of 0.01 people $\mathrm{m}^{-2}$ and has dimensions of people (disc) or people $\mathrm{m}^{-1}(\operatorname{arc})$.

Figure E3a. Infection Probabilities and Urban Infections Within a Disc Centered on the Release
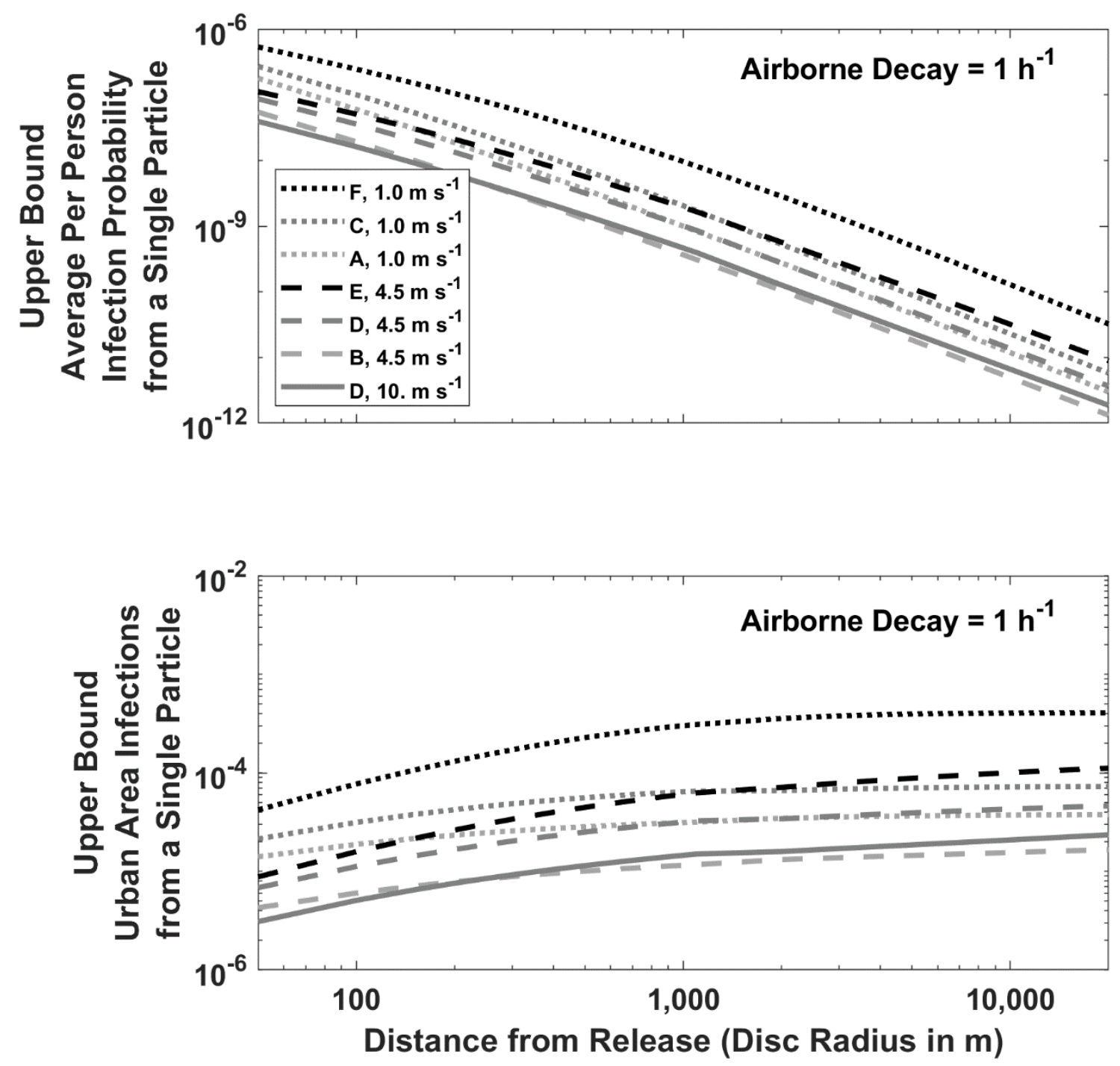
medRxiv preprint doi: https://doi.org/10.1101/2020.04.23.20076273; this version posted April 28, 2020. The copyright holder for this preprint (which was not certified by peer review) is the author/funder, who has granted medRxiv a license to display the preprint in perpetuity. It is made available under a CC-BY-NC-ND 4.0 International license .

M Dillon and Particle Model for C Dillon Airborne Disease Transmission

Figure E3b. Infection Probabilities and Urban Infections Along an Arc Centered on the Release Source
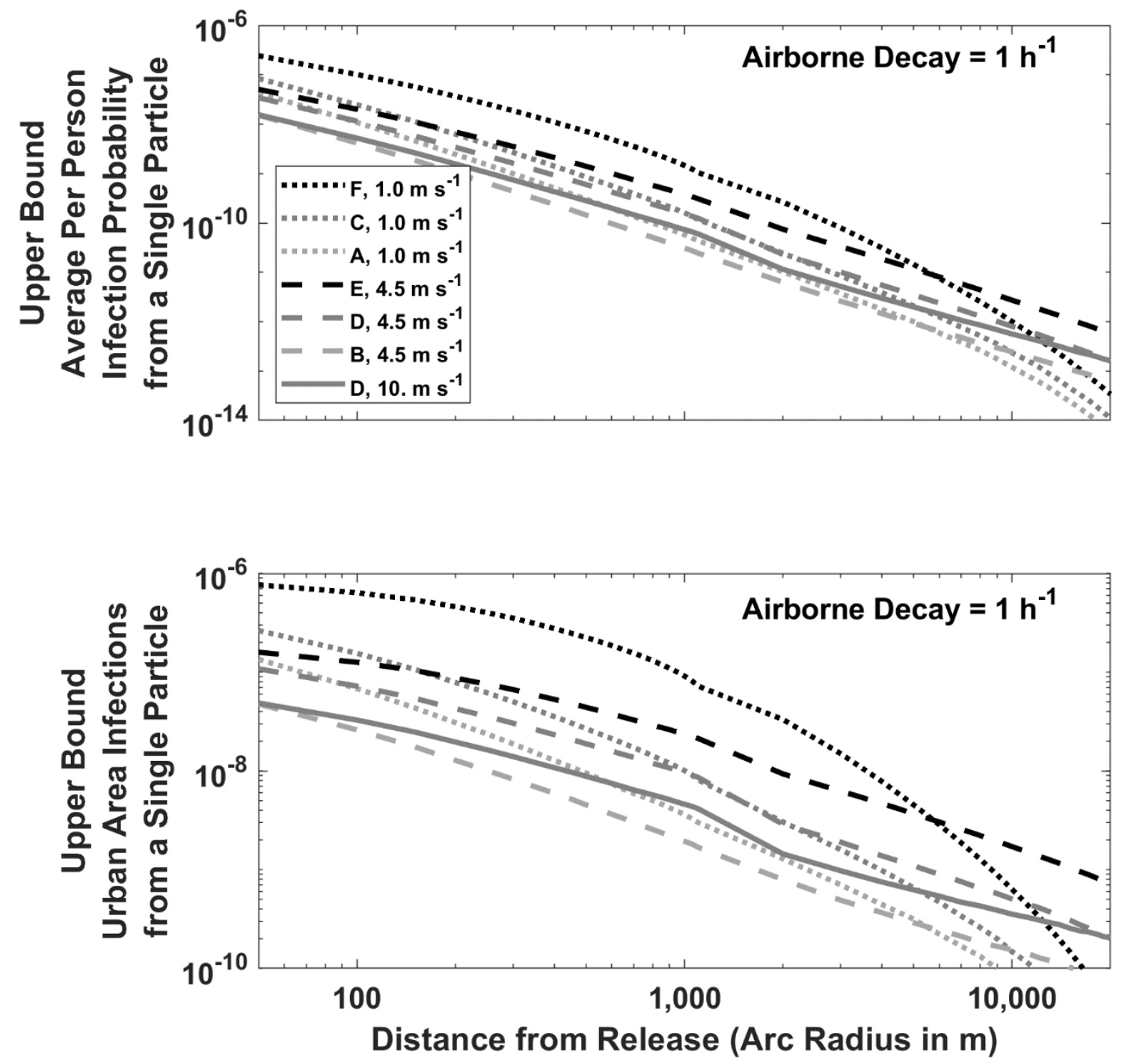
medRxiv preprint doi: https://doi.org/10.1101/2020.04.23.20076273; this version posted April 28, 2020. The copyright holder for this preprint (which was not certified by peer review) is the author/funder, who has granted medRxiv a license to display the preprint in perpetuity. It is made available under a CC-BY-NC-ND 4.0 International license .

M Dillon and C Dillon
Particle Model for Airborne Disease Transmission
2668

2669

2670

2671

2672

2673

Figure E4. Predicted absolute infection probabilities and infections by distance, wind speed and atmospheric stability for a single airborne particle with $10 \mathrm{~h}^{-1}$ airborne loss of infectivity. Legend indicates Pasquill-Gifford-Turner atmospheric stability class ( $A$ to $F$ ) and the $10 \mathrm{~m}$ agI wind speed. Individual person infection probability (top panels) is dimensionless. Urban area infections (bottom panels) a uniform population density of 0.01 people $\mathrm{m}^{-2}$ and has dimensions of people (disc) or people $\mathrm{m}^{-1}(\operatorname{arc})$.

Figure E4a. Infection Probabilities and Urban Infections Within a Disc Centered on the Release
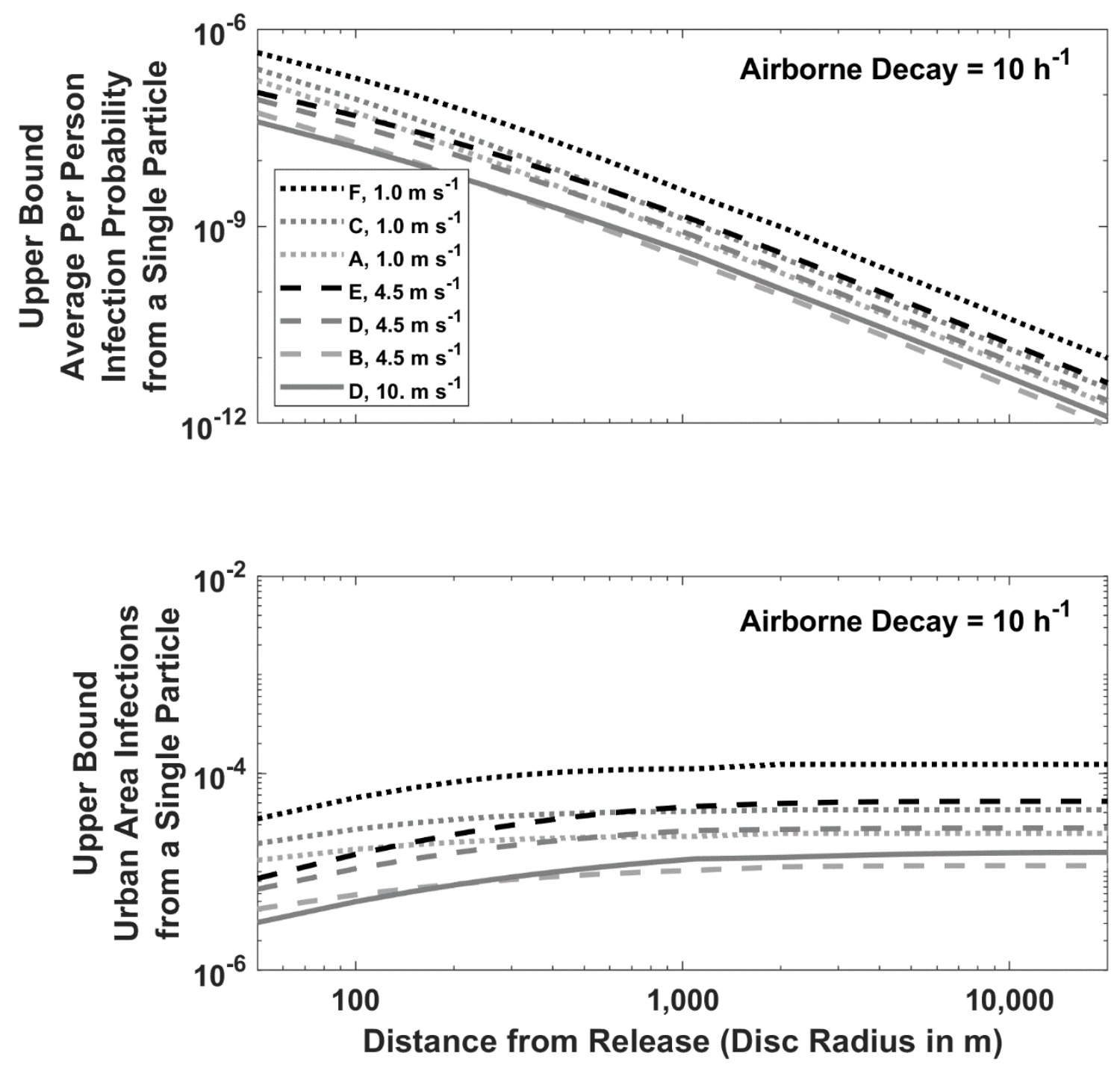
medRxiv preprint doi: https://doi.org/10.1101/2020.04.23.20076273; this version posted April 28, 2020. The copyright holder for this preprint (which was not certified by peer review) is the author/funder, who has granted medRxiv a license to display the preprint in perpetuity. It is made available under a CC-BY-NC-ND 4.0 International license .

M Dillon and Particle Model for C Dillon Airborne Disease Transmission

Figure E4b. Infection Probabilities and Urban Infections Along an Arc Centered on the Release Source
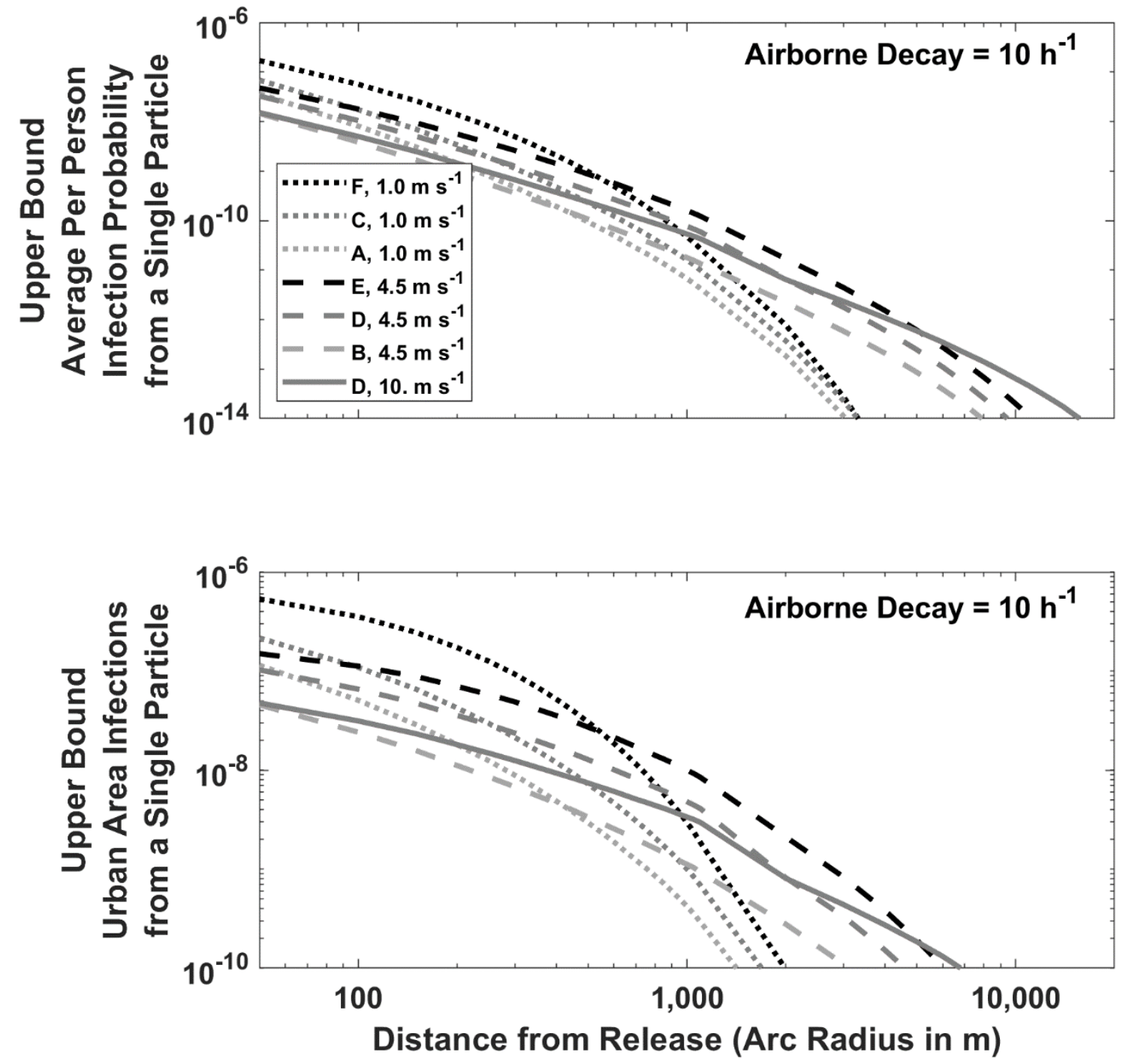
medRxiv preprint doi: https://doi.org/10.1101/2020.04.23.20076273; this version posted April 28, 2020. The copyright holder for this preprint (which was not certified by peer review) is the author/funder, who has granted medRxiv a license to display the preprint in perpetuity. It is made available under a CC-BY-NC-ND 4.0 International license .

M Dillon and

C Dillon
Particle Model for

Airborne Disease Transmission
2678

2679

2680

2681
Figure E5. Predicted relative infection probabilities by distance, wind speed and atmospheric stability for a single airborne particle with $\mathrm{O} \mathrm{h}^{-1}$ airborne loss of infectivity. Legend indicates Pasquill-Gifford-Turner atmospheric stability class ( $A$ to $F$ ) and the $10 \mathrm{~m}$ agl wind speed. Relative infection probability is dimensionless.

Figure E5. Relative Infection Probabilities as a Function of Distance from Release
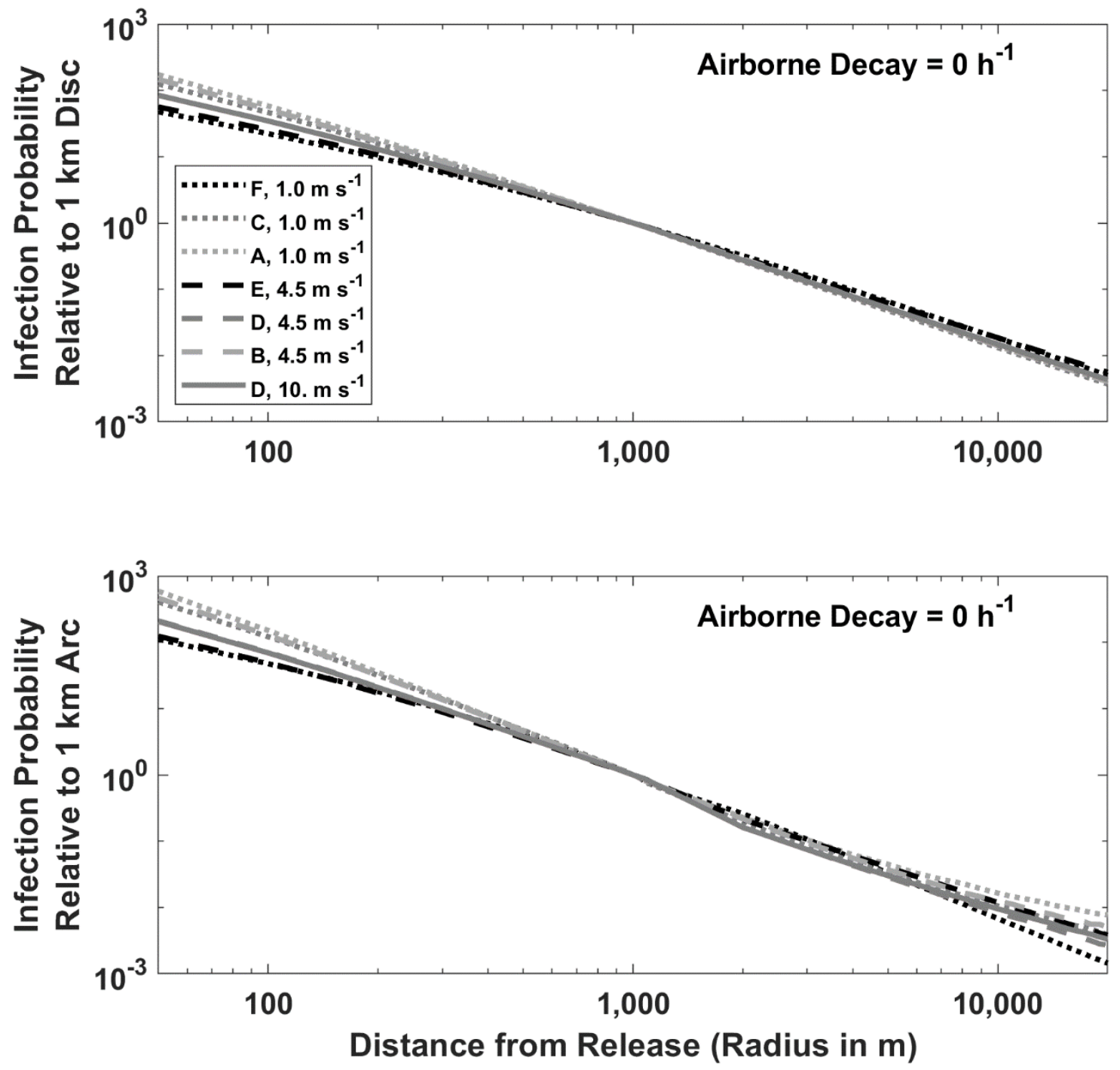
medRxiv preprint doi: https://doi.org/10.1101/2020.04.23.20076273; this version posted April 28, 2020. The copyright holder for this preprint (which was not certified by peer review) is the author/funder, who has granted medRxiv a license to display the preprint in perpetuity. It is made available under a CC-BY-NC-ND 4.0 International license .

M Dillon and

C Dillon
Particle Model for

Airborne Disease Transmission
2683

2684

2685

2686

Figure E6. Predicted relative infection probabilities by distance, wind speed and atmospheric stability for a single airborne particle with $0.1 \mathrm{~h}^{-1}$ airborne loss of infectivity. Legend indicates Pasquill-Gifford-Turner atmospheric stability class (A to F) and the $10 \mathrm{~m}$ agl wind speed.

Relative infection probability is dimensionless.

Figure E6. Relative Infection Probabilities as a Function of Distance from Release
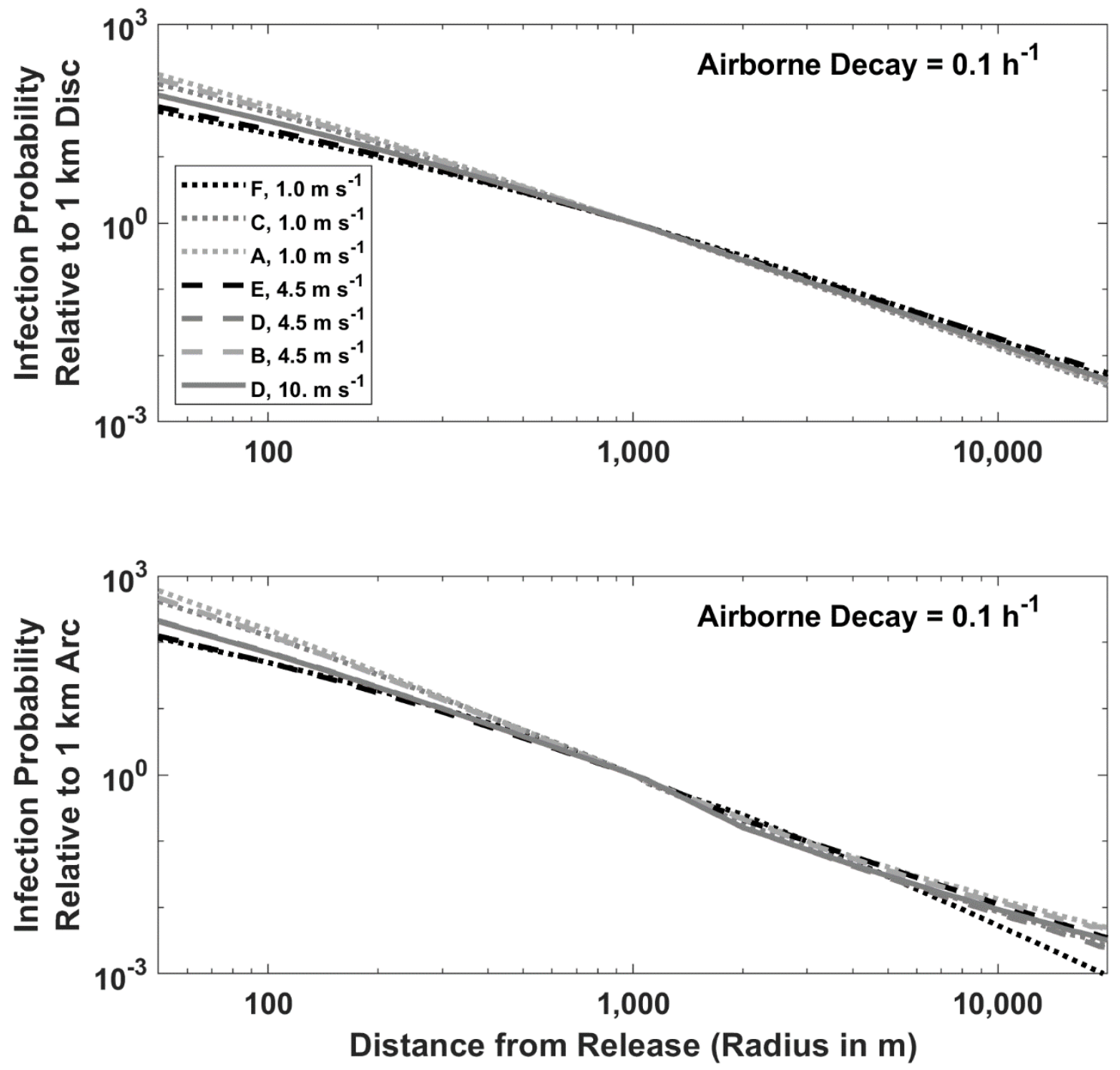
medRxiv preprint doi: https://doi.org/10.1101/2020.04.23.20076273; this version posted April 28, 2020. The copyright holder for this preprint (which was not certified by peer review) is the author/funder, who has granted medRxiv a license to display the preprint in perpetuity. It is made available under a CC-BY-NC-ND 4.0 International license .

M Dillon and

C Dillon
Particle Model for

Airborne Disease Transmission
2688

2689

2690

2691

Figure E7. Predicted relative infection probabilities by distance, wind speed and atmospheric stability for a single airborne particle with $1 \mathrm{~h}^{-1}$ airborne loss of infectivity. Legend indicates Pasquill-Gifford-Turner atmospheric stability class ( $A$ to $F$ ) and the $10 \mathrm{~m}$ agl wind speed. Relative infection probability is dimensionless.

Figure E7. Relative Infection Probabilities as a Function of Distance from Release
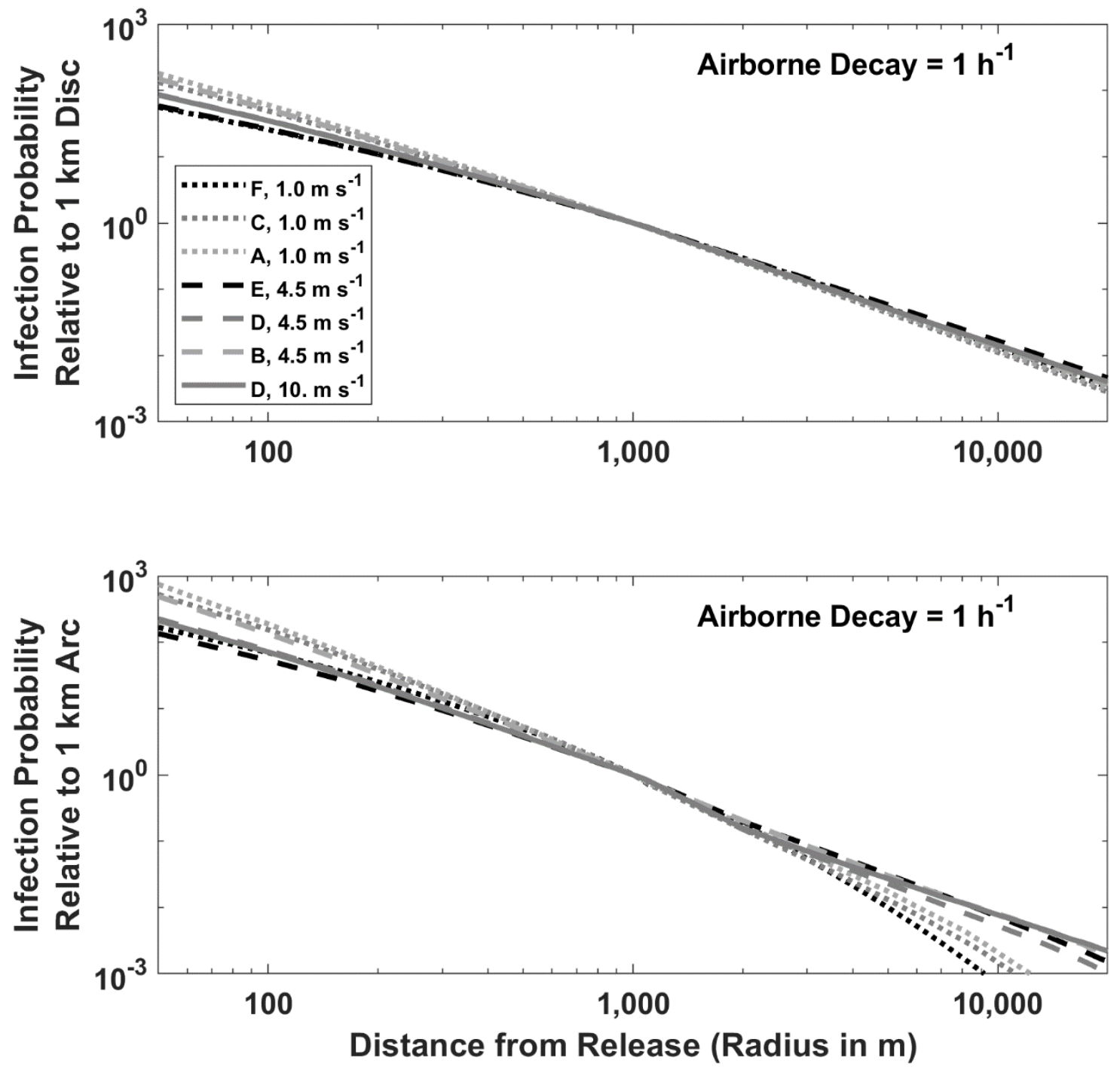
medRxiv preprint doi: https://doi.org/10.1101/2020.04.23.20076273; this version posted April 28, 2020. The copyright holder for this preprint (which was not certified by peer review) is the author/funder, who has granted medRxiv a license to display the preprint in perpetuity. It is made available under a CC-BY-NC-ND 4.0 International license .

M Dillon and

C Dillon
Particle Model for Airborne Disease Transmission
2693

2694

2695

2696

Figure E8. Predicted relative infection probabilities by distance, wind speed and atmospheric stability for a single airborne particle with $10 \mathrm{~h}^{-1}$ airborne loss of infectivity. Legend indicates Pasquill-Gifford-Turner atmospheric stability class ( $A$ to $F$ ) and the $10 \mathrm{~m}$ agl wind speed. Relative infection probability is dimensionless.

Figure E8. Relative Infection Probabilities as a Function of Distance from Release
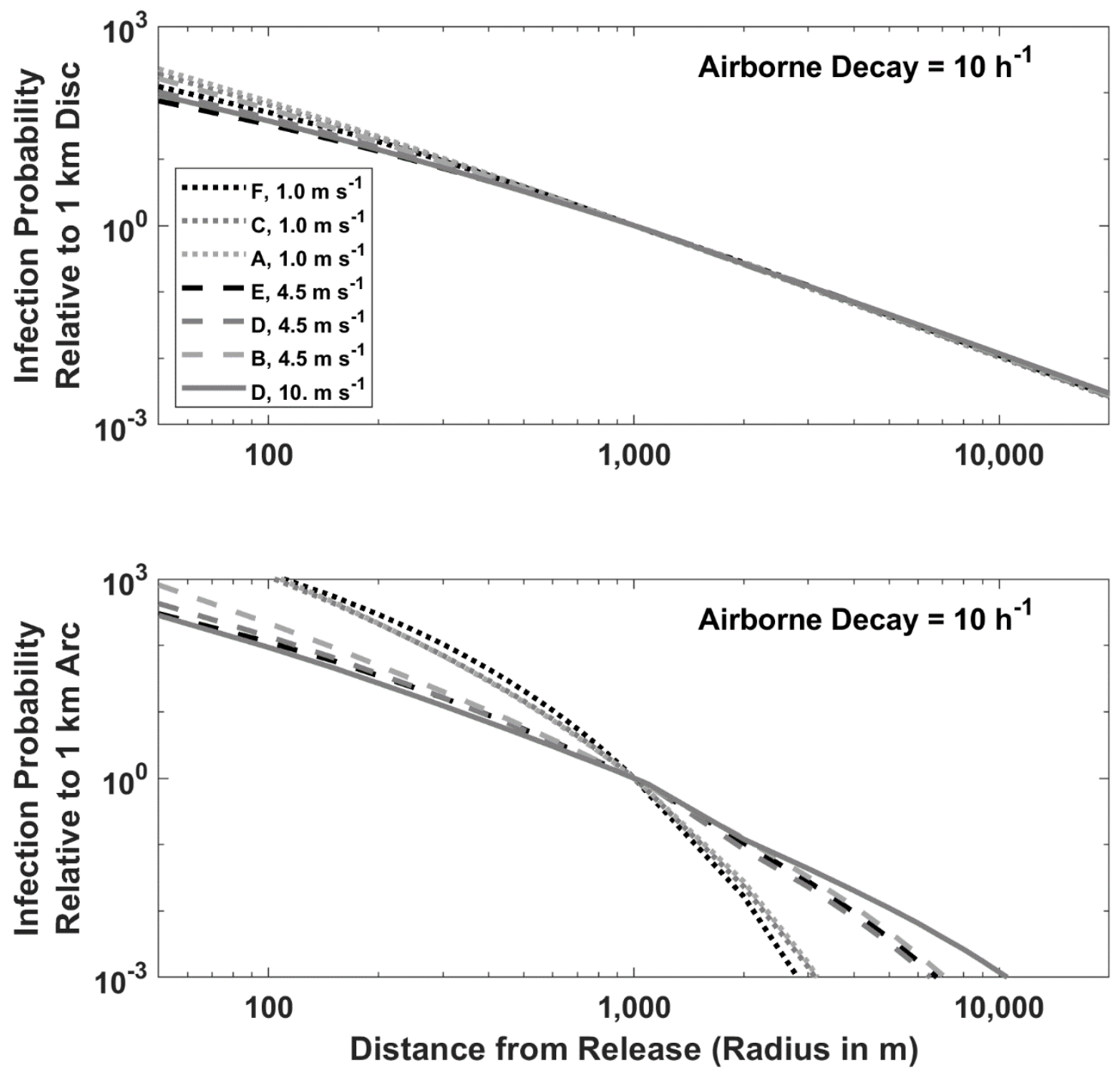
medRxiv preprint doi: https://doi.org/10.1101/2020.04.23.20076273; this version posted April 28, 2020. The copyright holder for this preprint (which was not certified by peer review) is the author/funder, who has granted medRxiv a license to display the preprint in perpetuity. It is made available under a CC-BY-NC-ND 4.0 International license .

M Dillon and

Particle Model for

C Dillon

Airborne Disease Transmission

2698 Supplemental Material F: Outbreak Model-Measurement Comparison

2699

2700 see companion excel spreadsheet

2701 
medRxiv preprint doi: https://doi.org/10.1101/2020.04.23.20076273; this version posted April 28, 2020. The copyright holder for this preprint (which was not certified by peer review) is the author/funder, who has granted medRxiv a license to display the preprint in perpetuity. It is made available under a CC-BY-NC-ND 4.0 International license .

M Dillon and

C Dillon

Particle Model for Airborne Disease Transmission

\section{Supplemental Material G: Infection Estimates}

\section{Section Variables Definitions}

2705

2706

particle type $=$ specifies particle size and infectivity as a function of time and environmental properties

$b=$ a specific particle type

$r=$ a specific geographic region

[Adjustment Factor] $(r, b)=$ scaling factor for region $r$ that accounts for the deviation of $b$ type particle exposure and response from that of the reference exposure and response (no units)

[Expected Number of Infections in Region] $(r, b)=$ number of infections in region $r$ resulting from exposure to $b$-type particles (people)

[Normalized TSIAC] $(r, b)=b$-type particle air concentration integrated over region $r$ and the passage of the airborne infectious plume assuming a single particle was released at the source $\left(\mathrm{s} \mathrm{m}^{-1}\right)$

[Population Density $](r)=$ population density in region $r\left(\right.$ people $\mathrm{m}^{-2}$ )

[Release Probability $](b)=$ probability that a particle released into the environment is a $b$ type particle (dimensionless)

2722 [Single Particle Infection Probability $]_{r e f}(r, b)=$ reference probability that an individual in region $r$ will become infected after being exposed to a single $b$-type particle. This term includes the probability that particle(s) will be inhaled and deposit in the respiratory

2726 [Source Adjustment Factor] $\left(r_{\text {source }}, b\right)=$ scaling factor that accounts for the deviation of $b$ -

2727 type particles emitted from the $r_{\text {source }}$ region from that of a reference source region (no 2728 units)

2729 [Total Particles Released] = total number of infectious, airborne particles released into the 2730 air (particles) 
medRxiv preprint doi: https://doi.org/10.1101/2020.04.23.20076273; this version posted April 28, 2020. The copyright holder for this preprint (which was not certified by peer review) is the author/funder, who has granted medRxiv a license to display the preprint in perpetuity. It is made available under a CC-BY-NC-ND 4.0 International license.

M Dillon and

Particle Model for

C Dillon

Airborne Disease Transmission

2731 Key Equation

2732

2733 Equation $\mathbf{G 1}$ is adapted from Equations $\mathbf{1}$ and $\mathbf{2}$ in the main text.

2734

2735

(Equation G1)

2736 [Expected Number of Infections in Region ] $(r, b)$

2737

$$
=\left(\begin{array}{c}
{[\text { Total Particles Released }]} \\
\cdot[\text { Release Probability }](b) \\
\cdot[\text { Source Adjustment Factor }]\left(r_{\text {source }}, b\right) \\
\cdot[\text { Single Particle Infection Probability }]_{\text {ref }}(r, b) \\
\cdot[\text { Adjustment Factor }](r, b) \\
\cdot[\text { Normalized TSIAC }](r, b) \\
\cdot[\text { Population Density }](r)
\end{array}\right)
$$

2738

2739 
medRxiv preprint doi: https://doi.org/10.1101/2020.04.23.20076273; this version posted April 28, 2020. The copyright holder for this preprint (which was not certified by peer review) is the author/funder, who has granted medRxiv a license to display the preprint in perpetuity. It is made available under a CC-BY-NC-ND 4.0 International license .

M Dillon and

C Dillon
Particle Model for Airborne Disease Transmission

Downwind Infections

[Expected Number of Infections in Region $](r, b)$

1) There is an approximately $20 \%$ chance of particles emitted indoors exiting the house assuming the $1 \mu \mathrm{m}$ diameter particles lose infectivity at a rate of $1 \mathrm{hr}^{-1}$ :

2) Each particle will cause infection if inhaled and each individual has a breathing rate of $10^{-4} \mathrm{~m}^{3} \mathrm{~s}^{-1}$ :

$[\text { Single Particle Infection Probability }]_{r e f}(r, b)=10^{-4} \mathrm{~m}^{3} \mathrm{~s}^{-1}$ particle $^{-1}$

3) Downwind individuals are fully susceptible, but are physically protected to same degree as typical US person is protected from an airborne, outdoor, $1 \mu \mathrm{m}$ diameter particle that losses infectivity at a rate of $1 \mathrm{hr}^{-1}$ :

4) Exposures occur in an urban area:

5) Downwind individuals are located between $50 \mathrm{~m}$ and $20 \mathrm{~km}$ from the infected person, the meteorology corresponds to clear night with a gentle breeze (stable atmospheric conditions and a $10 \mathrm{~m}$ agl wind speed of $4.5 \mathrm{~m} \mathrm{~s}^{-1}$ ), each particle has a $1 \mu \mathrm{m}$ aerodynamic diameter and the particle loses infectivity in the atmosphere at a rate of 1 $\mathrm{hr}^{-1}$ (see Table E4a):

$[$ Normalized TSIAC $](r, b)=56 s m^{-1}$ 
medRxiv preprint doi: https://doi.org/10.1101/2020.04.23.20076273; this version posted April 28, 2020. The copyright holder for this preprint (which was not certified by peer review) is the author/funder, who has granted medRxiv a license to display the preprint in perpetuity. It is made available under a CC-BY-NC-ND 4.0 International license .

M Dillon and

C Dillon
Particle Model for Airborne Disease Transmission

Within Building Assumptions

2767

2768

(Equation G3)

2769

2770

[Expected Number of Infections in Region $](r, b)$

$=4 \times 10^{-6} \cdot[$ Total Particles Released $] \cdot[$ Release Probability $](b)$

2771

2772

2773 Assumptions

2774

1) Airborne particles are released indoors:

2775

2776

2777

[Source Adjustment Factor] $\left(r_{\text {source }}, b\right)=1$

2778

2779

2) Each particle will cause infection if inhaled and each individual has a breathing rate of $10^{-4} \mathrm{~m}^{3} \mathrm{~s}^{-1}$ :

3) [Single Particle Infection Probability $]_{r e f}(r, b)=10^{-4} \mathrm{~m}^{3} \mathrm{~s}^{-1}$ particle p $^{-1}$

4) Indoor individuals are fully susceptible and are not protected:

$[$ Adjustment Factor $](r, b)=1$

5) There is one susceptible individual in a typical US home. For context, a typical US single family home has $200 \mathrm{~m}^{2}$ of heated floor area and 2 total residents (Tables HC10.14 and HC9.1, respectively, per [244]):

2785

2786

2787

2788

$[$ Population Density $](r)=0.005$ people $m^{-2}$

2789

6) Exposures are determined by Equation D7 using typical US home values [30] and an assumed room height of $3 \mathrm{~m}$. Each particle has a $1 \mu \mathrm{m}$ aerodynamic diameter and the particle loses infectivity at a rate of $1 \mathrm{hr}^{-1}$.

$[$ Normalized TSIAC $](r, b)=8.4 \mathrm{~s} \mathrm{~m}^{-1}$ 
medRxiv preprint doi: https://doi.org/10.1101/2020.04.23.20076273; this version posted April 28, 2020. The copyright holder for this preprint (which was not certified by peer review) is the author/funder, who has granted medRxiv a license to display the preprint in perpetuity. It is made available under a CC-BY-NC-ND 4.0 International license .

M Dillon and C Dillon Particle Model for Airborne Disease Transmission

\section{Supplemental Material H: U.S. Coxiella burnetti Infection and Disease Estimates}

2792 Q Fever is a veterinary disease of livestock that can be transmitted to humans by inhalation of

2793 infectious aerosols [61] and has caused significant community and regional level disease

2794 outbreaks, see Supplemental Material A: Airborne Disease Transmission Literature Review.

2795 Control measures exist for animal and human Q Fever and vaccines are available in some

2796 countries [245]-[248].

2797

2798

2799

\section{Background}

2800

In the 1930's, it was first recognized that exposure to infected livestock could cause human disease. During a 1935 disease outbreak, Q Fever was recognized in Australia. Initially the cause was unknown and so investigators called it "Query" (of questionable cause) Fever. The bacterium Coxiella burnetti, which causes Q Fever, was named after the two researchers who first identified it (Herald Cox and McFarlane Burnet). Since this time, Coxiella burnetti infection in animals has been shown to be common in almost all countries, including the United States [249] and causes significant disease in commercial livestock including, but not limited to, cows, sheep, and goats [250]. A recently summary indicates high US infection rates in goats (41.6\%), sheep (16.5\%), and cattle (3.4\%) [250].

In the US soils, an environmental survey demonstrates widespread contamination, with $23.8 \%$ of samples testing positive for Coxiella DNA [251]. US state-level positive sample rates range from 6 to 44\%. A subset of these samples was tested for viability and Coxiella was culturable in the PCR positive specimens. As expected, the Coxiella DNA was detected in locations with livestock; however, it was also often found in locations associated with human activity, such as post offices, stores, and schools. 
medRxiv preprint doi: https://doi.org/10.1101/2020.04.23.20076273; this version posted April 28, 2020. The copyright holder for this preprint (which was not certified by peer review) is the author/funder, who has granted medRxiv a license to display the preprint in perpetuity. It is made available under a CC-BY-NC-ND 4.0 International license .

M Dillon and

C Dillon
Particle Model for Airborne Disease Transmission

\section{Human Infection and Disease Characteristics}

2817 Q Fever in humans is characteristically caused by inhalation of airborne bacteria, although 2818 direct contact and ticks are also known infection pathways [61], [249]. The infectious aerosols may be emitted directly from infected animals or the result of aerosolization of contaminated particles or soil. Coxiella is highly infectious since exposure to only a few bacteria can cause infection ${ }^{42}$ and while there is some variation between research studies and also variation by infectious dosage, in general it is thought that $40 \%$ to $50 \%$ of humans infected for the first time become ill with Acute $Q$ Fever. The proportion of infected persons who will develop Chronic $Q$ Fever is still uncertain as it can be much more difficult to diagnose [61], [249], [252]-[254].

Acute Q Fever often exhibits as a short influenza-like illness, but the disease can be severe with pneumonia, liver disease, or encephalitis requiring hospitalization. Acute $Q$ Fever can lead to fatalities, with a death rate of 1 to $2 \%$ [61]. Pregnant women are considered to face the same risks as infected farm animals, namely increased risk abortion, stillbirth, and premature delivery [249]. High titers of subtype Phase II Q Fever antibody (IgG IFA $\geq 1: 128$ ) are considered supportive laboratory evidence for Acute $Q$ Fever infection and are often used as a surrogate surveillance measure for Q Fever in Public Health surveillance [61], [249], [255], [256]. In our prevalence analysis presented in the next subsection, we use a more selective definition for laboratory-supportive Acute $Q$ Fever infection to increase the likelihood of identifying true Acute $Q$ Fever associated infections. Specifically, we define Acute $Q$ Fever infection as a case with (a) Phase II IgG IFA $\geq 1: 128$, (b) Phase II antibodies $\geq 4 x$ Phase I antibodies, and (c) Phase I $\operatorname{lgG}$ IFA $<1: 800) .{ }^{43}$

Chronic $Q$ Fever is challenging to diagnose and also to treat with existing antibiotics. It causes significant heart disease and high mortality rates. Notably, Chronic Q Fever can develop in infected individuals who have never had Acute $Q$ Fever and so it may go unnoticed for years after the initial infection. It is usually fatal if left untreated [69], [249]. For example a 2018 follow up of a recent 2008 to 2010 outbreak showed that among the 519 chronic Q Fever cases identified, 86 patients had died [69]. A persistently high Phase I antibody level (IgG IFA 21:800) that persists after Acute $Q$ Fever infection is a risk factor for Chronic $Q$ Fever but is not diagnostic [61].

${ }^{42}$ The dose required to infect $50 \%$ of the human subjects is 1.18 bacteria ( $95 \% \mathrm{Cl}: 0.76$ to 40.2 ) [15], [83].

${ }^{43}$ Coxiella antibody "Phases" are a laboratory methods notation where Phase 1 antibodies occur first in embryonated egg cultures and Phase II antibodies later. In human Acute Q Fever, Phase II antibodies peak first at high levels ( $\geq 1: 128) 1$ to 2 weeks after the start of symptoms when Phase I antibody levels are low. Phase I antibodies peak some weeks after. Our selective acute infection criteria was chosen to reflect these dynamics and relevant human levels [61], [249]. 
medRxiv preprint doi: https://doi.org/10.1101/2020.04.23.20076273; this version posted April 28, 2020. The copyright holder for this preprint (which was not certified by peer review) is the author/funder, who has granted medRxiv a license to display the preprint in perpetuity. It is made available under a CC-BY-NC-ND 4.0 International license .

M Dillon and

C Dillon
Particle Model for

Airborne Disease Transmission

\section{Human Infection and Disease Prevalence}

It is uncertain how many human Coxiella infections and cases of $Q$ Fever there are as it is widely acknowledged that many, if not most, cases of $Q$ Fever are unrecognized and do not come to medical attention [61], [249]. Existing Q Fever disease notification systems are "passive" surveillance systems in which disease prevalence is determined by the number of cases diagnosed and then reported by medical providers [252]. 44 "Passive" surveillance systems, while useful for trends analysis and disease outbreak identification, undercount the disease prevalence as undiagnosed cases and persons without access to health care are not included. In contrast, "active" surveillance provides less biased estimates. "Active" surveillance consists of actively surveying the general population with a scientifically based sampling strategy and collecting data and blood samples to determine each person's infection or disease status.

While no country has national estimates of $Q$ Fever prevalence, we provide approximate estimates for US prevalence here. The US National Health and Nutrition Examination Survey (NHANES) used active surveillance to provide national representative Coxiella burnetti serum antibody levels in the 2003 to 2004 survey [62], [257]. ${ }^{45}$ Q Fever seroprevalence was determined by screening with an enzyme-linked immunosorbent assay and confirmed by using standard immunofluorescent antibody (IFA) testing [61]. The overall US prevalence of any positive antibody (any Phase I or Phase II IgG IFA $\geq 1: 16$ ) in US adults $20+$ years of age was 3.1\% of the population $(95 \% \mathrm{Cl} 2.1 \%$ to $4.3 \%)$ [62]. ${ }^{46,47}$ This suggests that 6.1 million persons $(95 \% \mathrm{Cl}$ : 4.2 to 8.5 million) have some type of $Q$ Fever infection, including acute infections, recovery phase of acute or chronic infections. We note that while a recent analysis of the NHANES data demonstrated a clear association with agricultural work, $80 \%$ of positive Coxiella NHANES test results were in persons working in non-agricultural sectors [258]. Similarly, 60\% of reported Q Fever cases had no association with farming or animal processing based on a review of cases in

${ }^{44}$ In the US there is mandatory reporting of Q Fever to the US Centers for Disease Control and Prevention national disease reporting system, see https://www.cdc.gov/qfever/info/index.html .

${ }^{45}$ The NHANES survey provides nationally representative estimates using a demographically-based complex, multistage survey design to minimize bias [62], [257].

${ }^{46}$ Antibody prevalence in men and woman was $3.8 \%$ and $2.5 \%$, respectively.

${ }^{47}$ NHANES 2003 to 2004 demographics and Coxiella serology data were downloaded from the NHANES website. Data assembly and analysis used SAS ${ }^{\mathrm{TM}}$ (Release 9.4, SAS Institute, Inc., Cary, NC). Survey design variables (strata and primary sampling units) and survey sample weights were used to account for differential probabilities of participant selection in the complex multistage survey design. Sample weights provide nationally representative estimates and adjust estimates for nonresponse and noncoverage. Statistical estimates are age-adjusted to the US population. Results with relative standard errors $>30 \%$, with $<12$ degrees of freedom, or low sample sizes are not presented. 
medRxiv preprint doi: https://doi.org/10.1101/2020.04.23.20076273; this version posted April 28, 2020. The copyright holder for this preprint (which was not certified by peer review) is the author/funder, who has granted medRxiv a license to display the preprint in perpetuity. It is made available under a CC-BY-NC-ND 4.0 International license .

M Dillon and C Dillon
Particle Model for Airborne Disease Transmission
2869

2870

2871

2872

2873

2874

2875

2876

2877

2878

2879

2880

2881

2882

2883

2884

2885

2886

2887

2888

the US Centers for Disease Control and Prevention's (CDC) National Notifiable Disease Surveillance System (NNDSS) and state and local US Public Health Departments [259].

\section{Acute Q Fever}

We further analyzed the NHANES 2003 to 2004 Coxiella dataset to estimate the US seroprevalence Acute Coxiella infection rates. Using the standard criterion (Phase II Q Fever antibody IgG IFA 21:128) [255], [256], laboratory supportive evidence of Acute Q Fever infection is $1.5 \%$ of the general US adult population ( $95 \% \mathrm{Cl}: 1.0 \%$ to $2.0 \%$ ). This corresponds to $20 \%$ of all positive tested samples, an estimated 2.5 million persons. Using our stricter definition, which has a higher likelihood of reflecting Acute Coxiella infection, the US population prevalence was $0.9 \%$ of the general US adult population ( $95 \% \mathrm{Cl}: 0.4 \%$ to $1.4 \%$ ), which corresponds to $15 \%$ of all positive tested samples and an estimated 1.9 million persons, see Table H1.

Assuming $40 \%$ of persons acutely infected with Coxiella will develop Q Fever, the US incidence of Acute Q Fever cases is estimated at $0.4 \%$ of the general US adult population ( $95 \% \mathrm{Cl}: 0.2 \%$ to $0.6 \%$ ), which corresponds to 820,000 adults ( $95 \% \mathrm{Cl}: 410,000$ to 1.2 million adults). Assuming a $1.5 \%$ fatality rate, this corresponds to 12,000 deaths ( $95 \% \mathrm{Cl}: 6,000$ to 18,000 ).

As previously mentioned, $70 \mathrm{Q}$ Fever cases were reported (passive surveillance) nationally in 2003 and 2004 and 153 Acute Q Fever cases were reported in 2017 [64]-[66]. 
medRxiv preprint doi: https://doi.org/10.1101/2020.04.23.20076273; this version posted April 28, 2020. The copyright holder for this preprint (which was not certified by peer review) is the author/funder, who has granted medRxiv a license to display the preprint in perpetuity.

It is made available under a CC-BY-NC-ND 4.0 International license .

M Dillon and

Particle Model for

C Dillon

Airborne Disease Transmission

Table H1. NHANES 2003 to 2004 Coxiella burnetti IFA Serology Prevalence Analysis

\begin{tabular}{|c|c|c|c|c|c|}
\hline & & Fraction & & CPS & CPS \\
\hline $\begin{array}{c}\mathbf{N} \\
\text { eople) }\end{array}$ & $\begin{array}{c}\text { Cases } \\
\text { (people) }\end{array}$ & $\begin{array}{c}\text { US } \\
\text { Adults } \\
(\%)\end{array}$ & $\begin{array}{c}95 \% \mathrm{Cl} \\
(\%)\end{array}$ & $\begin{array}{c}\text { Total } \\
\text { (million } \\
\text { people) }\end{array}$ & $\begin{array}{l}95 \% \mathrm{Cl} \\
\text { (million } \\
\text { people) }\end{array}$ \\
\hline
\end{tabular}

General Serology Estimates

\begin{tabular}{|c|c|c|c|c|c|c|}
\hline Any Positive QF Serology $\geq 1: 16$ & 4437 & 180 & 3.1 & 2.1 to 4.3 & 6.1 & 4.2 to 8.5 \\
\hline $\begin{array}{c}\text { All QF Phase II Serologies } \geq \\
1.128\end{array}$ & 4437 & 91 & 1.5 & 1.0 to 2.0 & 3.1 & 2.1 to 4.1 \\
\hline
\end{tabular}

More Selective Serology Estimates

$\begin{array}{lllllll}\text { Acute Q Fever Supportive } & 4437 & 50 & 0.9 & 0.4 \text { to } 1.4 & 1.9 & 0.8 \text { to } 2.9\end{array}$

$\begin{array}{lllllll}\text { All Other QF Positive Serologies } \quad 4437 & 130 & 2.2 & 1.3 \text { to } 3.1 & 4.5 & 2.7 \text { to } 6.4\end{array}$

2890

2891

2892

2893

2894

2895

2896

2897

2898

2899

2900

2901

Abbreviations:

$\mathrm{N}=$ total sample; $\%$ = prevalence $; 95 \% \mathrm{Cl}=95$ th $\%$ confidence interval; $\mathrm{CPS}=$ US Census Current Population Survey (US adult population); QF = Q Fever; IFA = antibody Immunofluorescence Assay; Phase II = initial acute disease QF IgG antibodies.

Notes:

Phase II QF antibodies $\geq 1: 128$ is US Centers for Disease Control \& Prevention definition of laboratory supportive evidence of acute Q Fever infection; Selective Acute QF Supportive infection definition is Coxiella (Phase II antibody $\geq 1: 128$; Phase II IgG IFA $\geq 4 x$ Phase I IgG IFA; and Phase I IgG IFA < 1:800). Total 2003 to 2004 US adult population is 205,284,670 people. 
medRxiv preprint doi: https://doi.org/10.1101/2020.04.23.20076273; this version posted April 28, 2020. The copyright holder for this preprint (which was not certified by peer review) is the author/funder, who has granted medRxiv a license to display the preprint in perpetuity. It is made available under a CC-BY-NC-ND 4.0 International license .

M Dillon and C Dillon
Particle Model for Airborne Disease Transmission

\section{Comparison to Prior Work}

2903 Prior studies suggest that the Q Fever prevalence estimates derived above may be plausible. 2904 First, the overall US population Coxiella infection rate of 3.1\% is similar to that reported in 2905 major European outbreak studies that used IFA testing. Second, a small-scale CDC methodology 2906 study examined the 2000 to 2011 Q Fever mortality case underreporting using Capture2907 Recapture Analysis. Reported Q Fever cases in the US National Death Index $(n=25)$ were 2908 compared to the CDC reported Q Fever case fatalities $(n=9)$. While strongly limited by small 2909 sample sizes, this study estimated a total of 129 fatal Q Fever cases ( $95 \% \mathrm{Cl}: 62$ to 1,250 cases) 2910 occurred nationally over this time period [259]. Third, the CDC also performed a separate 2911 Coxiella seroprevalence study using data from US commercial medical laboratories from tests 2912 ordered by medical providers to evaluate symptomatic patients. While this latter survey was 2913 not nationally representative, 16\% $(2,039)$ of the 12,821 specimens tested were positive for 2914 Coxiella [255]. Finally, serological analysis of stored sera from population-based epidemiology 2915 studies and medical diagnostic laboratory testing shows Coxiella burnetti infection prevalence 2916 rates in other countries is similar to those seen in the United States (Netherlands 2.4\%;

2917 Australia 5.6\%) [260], [261]. 